\title{
Analysis Results for Building 241 702-AZ A Train
}

J. B. Duncan et al.

CH2M HILI Hanford Group, Inc.

Richland, WA 99352

U.S. Department of Energy Contract DE-AC27-99RL14047

EDT/ECN: DRE

Cost Center: 7\$110

B\&R Code:
UC:

Charge Code:

Total Pages: / 61

Key Words: sampling, analys1s, results, 702-Az, A train, PER, PCB, crystaline, methods, requirements, trypticase soy agar, Sabouraud dextrose agar, biological, chemical analysis, microbiological analysis

Abstract: This report presents the analyses results for three samples obtained under RPP-PLAN-28509, Sampling and Analysis Plan for Building 241 702-AZ A Train. The sampling and analysis was done in response to problem evaluation request number PER-2004-6139, 702-AZ Filter Roors Need Radiological Cleanup Efforts.

TRADEMARK DISCLAIMER. Reference hereln to any specific commercial product, process, or service by trade name, trademark, manufacturer, or othenulse, does not necassarfly constitute or imply its endorserment, recommendation, or favoring by the United States Govemment or any agency thereof or its contractors or subcontractors.

Printed In the United Stales of America. To obtain copies of this document, contact: Document Control Services, P.O. Box 950, Mailstop \$6-08, Richland WA 99352, Phone (509) 372-2420; Fax (509) 376-4989.

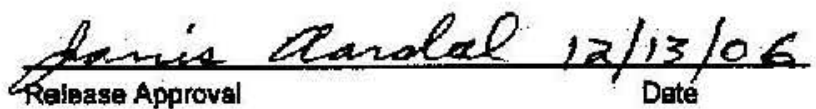

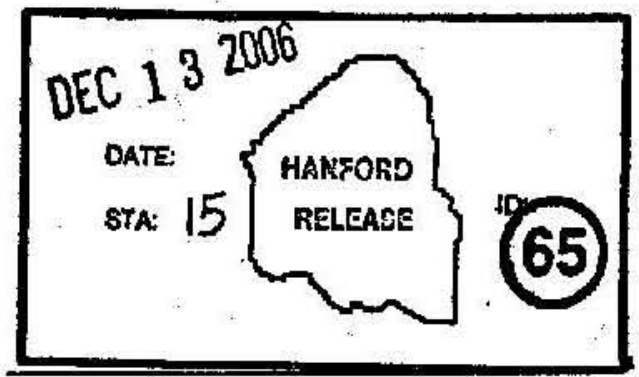

Release Stamp 


\title{
Analysis Results for Building 241 702-AZ A Train
}

\author{
J. B. Duncan \\ J. M. Frye \\ G. A. Cooke \\ CH2M HILL Hanford Group, Inc.
}

S. W. Li

F. J. Brockman

Pacific Northwest National Laboratory

Date Published

December 2006

\section{CH2MHILL \\ Hanford Group, Inc.}

Prepared for the U.S. Department of Energy

Office of River Protection

Contract No. DE-AC27-99RL14047

Approved for public release; distribution is unlimited 


\section{Table of Contents}

\section{ACRONYMS iii}

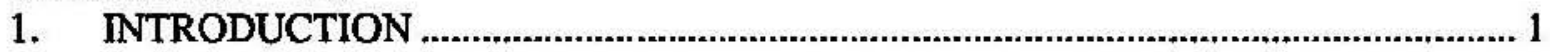

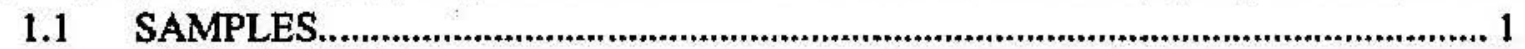

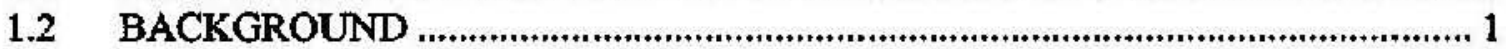

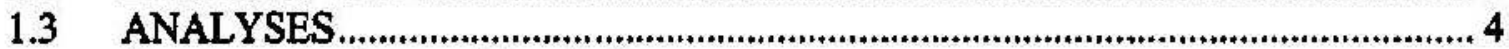

1.4 SAMPLE IDENTIFICATION................................................................ 4

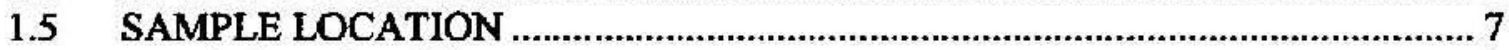

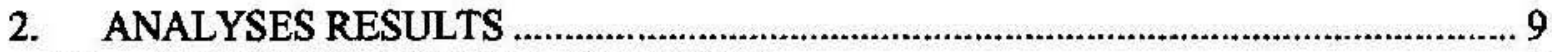

2.1 MICROBIOLOGICAL ANALYSES ........................................................

2.1.1 Surface Enumeration........................................................................... 9

2.1.2 Dilution Plate Counts................................................................................. 9

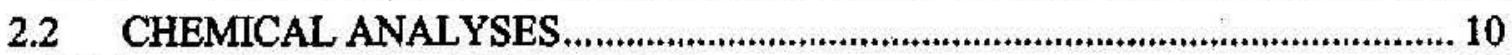

2.2.1 Material from 702AZ A-Train ............................................................... 10

2.2.2 Analyses of Material Internal to Pipe Segment .............................................. 13

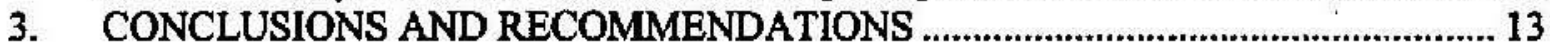

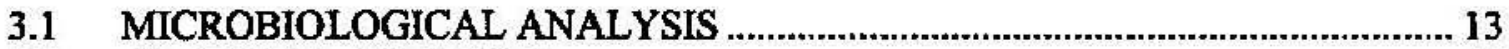

3.2 CHEMICAL ANALYSIS ................................................................................ 16

3.3 PATH FORWARD FOR CLEANING AND DISPOSING OF EXTERNAL VENT DUCT AND FLOOR MATERIALS........................................................16

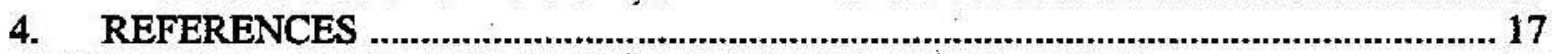

APPENDIX A FIELD SAMPLING REPORTS FROM DURATEK ……........................A-i

APPENDIX B LABORATORY SAMPLE BREAKDOWN DIAGRAMS ....................... B-i

APPENDIX C MICROBLAL MEDIA AND PLATE COUNT RAW DATA .................... C-i

APPENDIX D ANALYTICAL RESULTS ......................................................

APPENDIX E SCANNING ELECTRON MICROSCOPY................................................ E-i

APPENDIX F POLARIZED LIGHT MICROSCOPY RESULTS..........................................

APPENDIX G X-RAY DIFFRACTION RESULTS ……............................................ G-i

APPENDIX H SCANNING ELECTRON MICROSCOPY OF SAMPLE S06E001029

(PIPE) ........................................................................................

\section{List of Figures}

Figure 1. Unknown External Ventilation Duct Crystalline Substance....................................2

Figure 2. Unknown Brownish-black Floor Material.............................................................3

Figure 3. 702-AZ Ventilation Building. ...........................................................................

Figure 4. Sample location for External Ventilation Duct Crystalline Material. .........................7

Figure 5. Sample Location for Floor Material..............................................................8

Figure 6. Microbiological Surface Sample Locations. ...............................................................8

Figure 7. Uncontaminated Concrete Microbiological Control Sample Location......................9

Figure 8. Results of Surface Enumeration by Contact Plate.....................................................14

Figure 9. Radioactivity (dpm) in Contact Plate.........................................................14

Figure 10. Microbial Population in Solid Materials by Dilution Plate Counts.........................15 


\section{RPP-RPT-31293, Rev. 0}

\section{List of Tables}

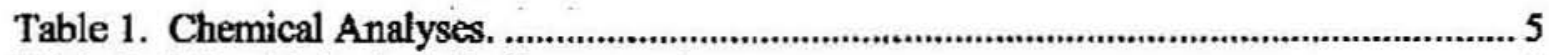

Table 2. Microbiological Analyses. ...................................................................................... 5

Table 3. Field Sample Identification............................................................................... 6

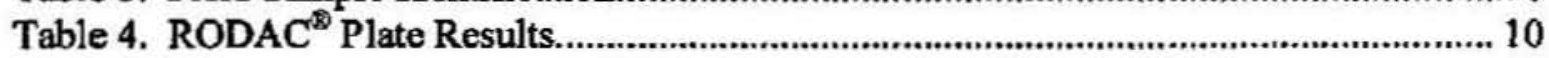

Table 5. Microbial Plate Count Results........................................................................... 10

Table 6. Initial Aralytical Results for SO6E001025 (crystalline material) and SO6E001026 (floor material)

Table 7. Analysis Results of SO6E001025 (crystalline material) and SO6E001042 (blended floor sample).

Table 8. Results of Differential Scanning Calorimetry. 
RPP-RPT-31293, Rev. 0

\section{ACRONYMS}

$\begin{array}{ll}\text { CFU } & \text { colony-forming units } \\ \text { DSC } & \text { differential scanning calorimetry } \\ \text { EDS } & \text { energy dispersive X-ray spectroscopy } \\ \text { GEA } & \text { gamma energy analysis } \\ \text { GM } & \text { Geiger-Mueller } \\ \text { HEMA } & \text { high-efficiency mist eliminator } \\ \text { HEPA } & \text { high-efficiency particulate air } \\ \text { IC } & \text { ion chromatography } \\ \text { ICP } & \text { inductively coupled plasma spectroscopy } \\ \text { NA } & \text { not applicable } \\ \text { PCB } & \text { polychlorinated biphenyls } \\ \text { PER } & \text { problem evaluation request } \\ \text { PBS } & \text { phosphate buffered saline } \\ \text { PLM } & \text { polarized light microscopy } \\ \text { PPE } & \text { personal protective equipment } \\ \text { RODAC } & \text { replicate organism detection and counting. A registered trademark of B-D } \\ & \text { Laboratories, West Chester, Pennsylvania } \\ \text { SAB } & \text { Sabouraud dextrose agar } \\ \text { SEM } & \text { scanning electron microscopy } \\ \text { TGA } & \text { thermogravimetric analysis } \\ \text { TOC/TIC } & \text { total inorganic carbon/total inorganic carbon } \\ \text { TSA } & \text { trypticase soy agar } \\ \text { XRD } & \text { X-ray diffraction }\end{array}$




\section{INTRODUCTION}

\subsection{SAMPLES}

This report presents the analyses results for three samples obtained under RPP-PLAN-28509, Sampling and Analysis Plan for Building 241 702-AZ A Train. The samplcs are cntered into the 222-S Laboratory LABCORE system as S06E001025 for the external ventilation duct crystalline material, S0E6001026 for the floor material, SO6E001042 for the resampled floor material blended with SOE6001026, and S06E001029 for a pipe section from the tie-in line between AZ-702 and AZ-301. The field sampling reports are contained in Appendix A. The laboratory sample identification is presented in Appendix B. Samples are reported by the primary LABCORE number as indicated above and then by subsamples for the different analyses performed. For example, the external ventilation dust crystalline material identified as SO6E001025 is further divided into subsamples identified as SO6E001034 (IC-NH $)_{4}$, SO6E001035 (ICP-RECRA Metals), SO6E001036 (IC-Anions/Small Org), SOE6001037 (SVOA Extraction), and S06E001045 (DSC-TA). The results are reported in this final report under SO6E001025. The pipe section contained only enough material to perform a scanning electron microscopy (SEM) analyses; therefore microbiological analysis was not performed on this sample as originally planned.

The sampling and analysis was done in response to problem evaluation request (PER) number PER-2004-6139, “702-AZ Filter Rooms Need Radiological Cleanup Efforts." This PER described an unknown condition within the 702-AZ Ventilation System Filter Room A caused by leakage of a crystalline substance from around the heater section and subsequent accumulation on the floor. Sampling of the unknown substances was recommended by the PER "with complete disclosure of chemical, radiological and biological results." Based on the sample results, personnel protective equipment (PPE) can be prescribed for performing the necessary facility repairs, clean-up, and decontamination.

\subsection{BACKGROUND}

The 702-AZ train is used to filter emissions from the ventilation of the primary tank headspaces in double-shell tanks 241-AY-101 (AY-101), 241-AY-102 (AY-102), 241-AZ-101 (AZ-101), and 241-AZ-102 (AZ-102). When the 702-AZ yentilation system was first put into service in March 1998, condensate buildup and internal flooding was experienced throughout the 702-AZ system. The " $\mathrm{A}$ "-side parallel exhaust clean-up train was being operated at the time that flooding occurred. As a result of the event, the unit was shut down to remedy the problem, and therefore the 702-AZ parallel B-train was not exposed to the liquid. It was not immediately obvious that the high-efficiency particulate air (HEPA) filter on the A-train was wet. When this was noted, the HEPA filters were changed on both trains. The heater section upstream of the HEPA filters on the A-train was found to be wet also, and the system was dried out as much as possible with rags. The presence of condensate in the system and additional leakage appears to be intermittent and may be dependent on waste-intrusive work activity in the tanks, as well as the operational efficiency of the tank ventilation system moisture removal subsystems. 
In 2004, the 702-AZ condensate drainage and collection system experienced plugging, primarily in the drain from the seal pot to the condensate receiver catch tank. Efforts to investigate and clear drainage problems revealed that a construction test blank was left in place in the drain from the primary condenser during systems startup in 1998, which caused the condenser to fill up with condensate and carry over entrained moisture (e.g., droplets, mists) into adjoining ductwork and equipment. Condensate seal pot drainage problems also caused condensate back-up into the high-efficiency mist eliminator (HEME), contributing to carry-over of entrained moisture in the air stream to the exhaust HEPA filter clean-up trains. Intermittent operation of individual tank ventilation recirculation cooling loops also contributed to high system moisture content and resultant condensate in the system.

Leakage from the 702-AZ Filter Room A heater section and onto the floor was first documented in operator routine-round data sheets in April 2004, and subsequently reported April 16, 2004, in PER-2004-2155, "702-AZ Filter Room Area Posted High Contamination Area." A work package was generated to decontaminate the area. Before initiating the clean-up effort, sampling and analysis of the deposits formed from the leak was required to prescribe appropriate PPE (see PER-2004-6139).

In Spring 2006, condensate drain system plugging again contributed to back-up of condensate into the ventilation system. As before, carry-over of entrained moisture from the HEME to the filter clean-up trains occurred, where it was primarily collected in the airstream heater sections upstream of the exhaust HEPA filters. Additional leakage from the heater section as a result of this event appears likely due to the moist appearance of the deposits.

The same external leakage problem is not as apparent for the B-train housing as it is on the A-train. Over the last 2 years B-train has been operated more than A-train. Figure 1 shows a crystalline substance emanating from behind the heater housing stainless-steel facc flange of the A-train (left arrow). Also, there appears to be additional material and/or corrosion products accumulating below the lower edge of the heater face flange (right arrow).

Figure 1. Unknown External Ventilation Duct Crystalline Substance.

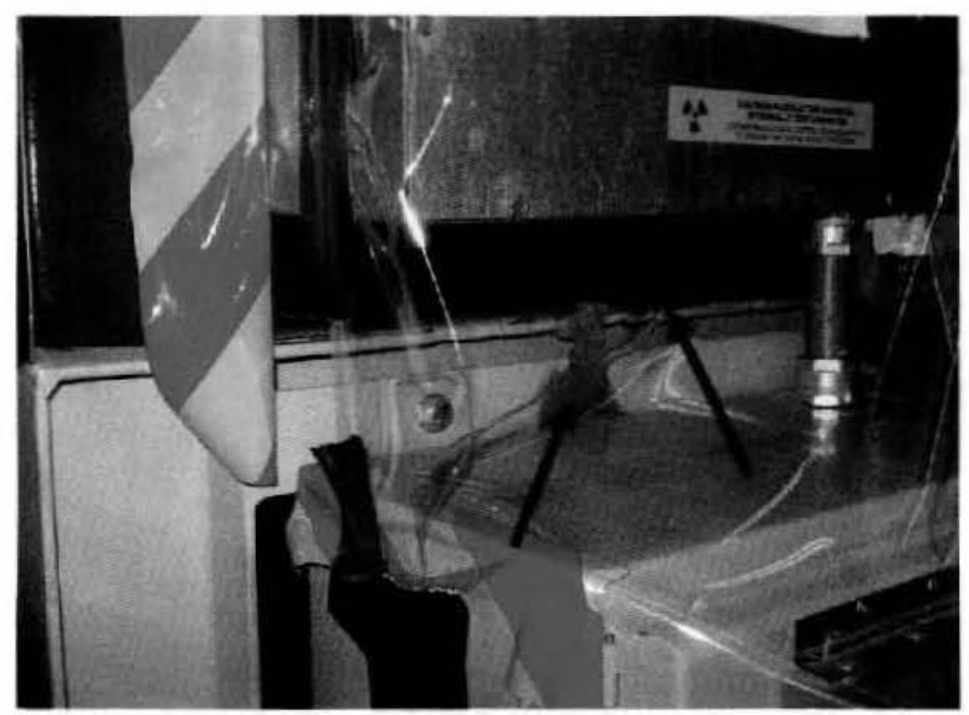




$$
\text { RPP-RPT-31293, Rev. } 0
$$

Figure 2 shows an area with material on the floor directly below the A-train heater housing and some staining. The area of interest is indicated by the lower arrow. The area indicated by the lower arrow may be the accumulation from the initial ventilation duct "leak" site and the upper arrow could indicate material that seeped under the I-beam. This floor material was found directly beneath the crystalline material shown in Figure 1.

Figure 2. Unknown Brownish-black Floor Material.

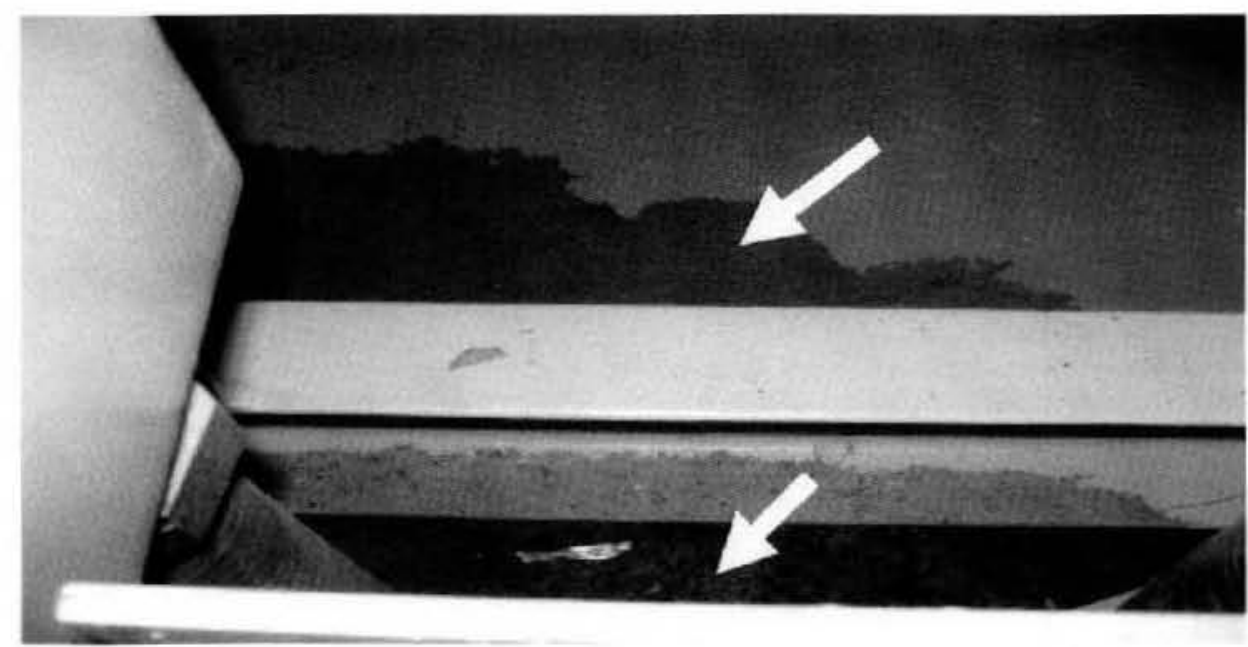

Samples of the crystalline substance external to the A-train heater section and the material deposited on the floor were collected on May 25, 2006, and submitted to the 222-S Laboratory for chemical and physical analysis to characterize the unknown materials. The floor material was resampled on July 31,2006 , to supplement the small amount of material obtained in May 2006. Additional samples were obtained at various locations during the May 2006 sampling event for microbiological analysis to evaluate potential biological hazards. The primary area of concern leading to the sampling event is Filter Room A located in Building $702-\mathrm{AZ}$ as shown in Figure 3.

The 702-AZ Ventilation System is described in detail in RPP-15127, System Design Description for AY and AZ Tank Farm Primary Ventilation System (DSA-Based), and shown in Figure 3. The system description includes the system functions, requirements, facility layout, flow diagrams, major components, configuration, operation, and maintenance. 
Figure 3. 702-AZ Ventilation Building.

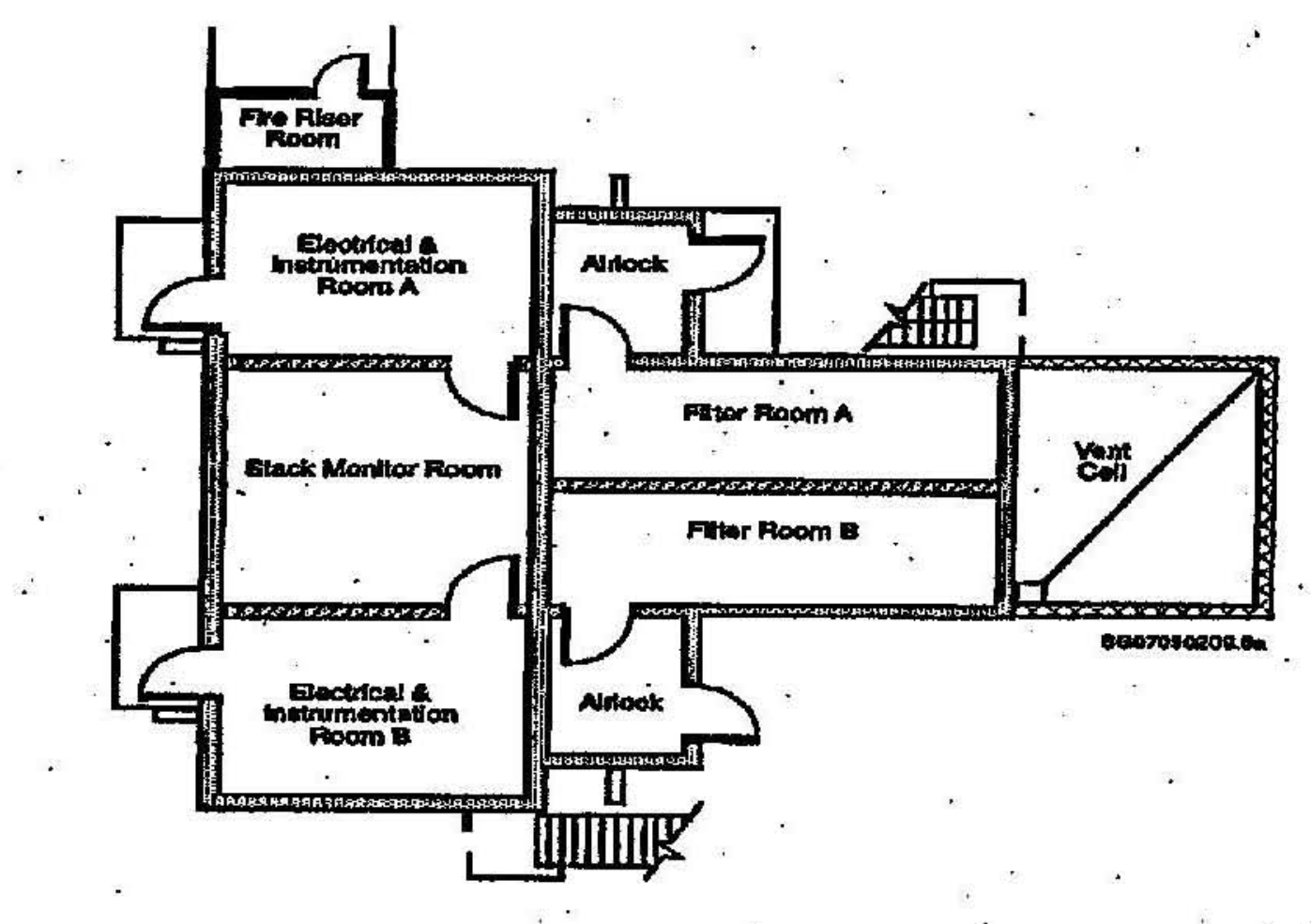

\subsection{ANALYSES}

The samples of the duct crystalline material and the floor substance were subjected to microbiological and chemical analyses. Analytical grade ammonium nitrate and ammonium nitrate mixed with sodium chloride were also analyzed for their thermal behavior. The chemical analyses performed are shown in Table 1. The microbiological analyses conducted are shown in Table 2.

\subsection{SAMPLE IDENTIFICATION}

Table 3 shows the field sample identification numbers, sample types, associated analyses, and sample locations for all the samples taken except for a sample of piping. The pipe section, removed during tie-in of the new AZ-301 condensate receiver tank to the 702-AZ ventilation building, had an unknown substance adhering to a small area on its inside surface. 
RPP-RPT-31293, Rev. 0

Table 1. Chemical Analyses.

\begin{tabular}{|l|l|}
\hline \multicolumn{1}{|c|}{ Analysis } & Analyses \\
\hline Gamma energy analysis (GEA) & $\begin{array}{l}\text { Radionuclide speciation (will describe radioactive isotopes } \\
\text { present in the samples) }\end{array}$ \\
\hline $\begin{array}{l}\text { Scanning electron microscopy with energy } \\
\text { dispersive X-ray spectroscopy }\end{array}$ & $\begin{array}{l}\text { Morphology, particle identification, with elemental } \\
\text { analysis }\end{array}$ \\
\hline Polarized light microscopy (PLM) & Optical microscopy to gather crystalline phase information \\
\hline X-ray diffraction (XRD) & $\begin{array}{l}\text { Identification of compounds associated with the crystalline } \\
\text { mass }\end{array}$ \\
\hline Solid pH & pH of the samples \\
\hline Polychlorinated biphenyls (PCB) screen & $\begin{array}{l}\text { Necessary for the lab to properly dispose of waste from } \\
\text { analyses unless there is prior knowledge of sample PCB } \\
\text { content }\end{array}$ \\
\hline $\begin{array}{l}\text { Differential scanning calorimetry (DSC) and } \\
\text { thermogravimetric analysis (TGA) }\end{array}$ & $\begin{array}{l}\text { Measurement of the thermal transition of a sample (DSC); } \\
\text { measurement of the weight loss of a sample (TGA). }\end{array}$ \\
\hline Ammonium & Ammonium ion \\
\hline $\begin{array}{l}\text { Water digest followed by ion } \\
\text { chromatography }\end{array}$ & $\begin{array}{l}\text { Anions (fluoride, chloride, nitrite, nitrate, bromide, } \\
\text { phosphate, sulfate, formate, acetate, glycolate, oxalate) in } \\
\text { the water soluble fraction of the solid samples }\end{array}$ \\
\hline $\begin{array}{l}\text { Acid digestinductively coupled plasma } \\
\text { spectroscopy }\end{array}$ & $\begin{array}{l}\text { Metal cations in the acid-digested sample of the solids } \\
\text { (most metals except mercury) }\end{array}$ \\
\hline Total inorganic carbon/total organic carbon & Total inorganic carbon and total organic carbon. \\
\hline $\begin{array}{l}\text { Organic extract'gas chromatography-mass } \\
\text { spectroscopy analysis }\end{array}$ & $\begin{array}{l}\text { Identification and quantification of organic soluble organic } \\
\text { compounds present in the solids }\end{array}$ \\
\hline $\begin{array}{l}\text { DSC using analytical-grade ammonium } \\
\text { nitrate }\end{array}$ & $\begin{array}{l}\text { Measurement of the thermal transition of analytical-grade } \\
\text { ammonium nitrate }\end{array}$ \\
\hline $\begin{array}{l}\text { DSC using analytical-grade ammonium } \\
\text { nitrate plus chloride }\end{array}$ & $\begin{array}{l}\text { Measurement of the effects of chloride at 0.2 wt\% on the } \\
\text { thermal transition of ammonium nitrate }\end{array}$ \\
\hline
\end{tabular}

Table 2. Microbiological Analyses.

\begin{tabular}{|l|l|c|}
\hline \multicolumn{1}{|c|}{ Sample } & \multicolumn{1}{|c|}{ Analysis } & \multicolumn{1}{c|}{ Analyte } \\
\hline Crystalline material & $\begin{array}{l}\text { Microbiological total population enumeration per unit } \\
\text { mass. }\end{array}$ & Bacteria/fungi \\
\hline $\begin{array}{l}\text { Floor stain, brownish-black } \\
\text { material on floor }\end{array}$ & $\begin{array}{l}\text { Microbiological surface enumeration per unit area and } \\
\text { per unit total mass. }\end{array}$ & Bacteria/fungi \\
\hline
\end{tabular}


Table 3. Field Sample Identification.

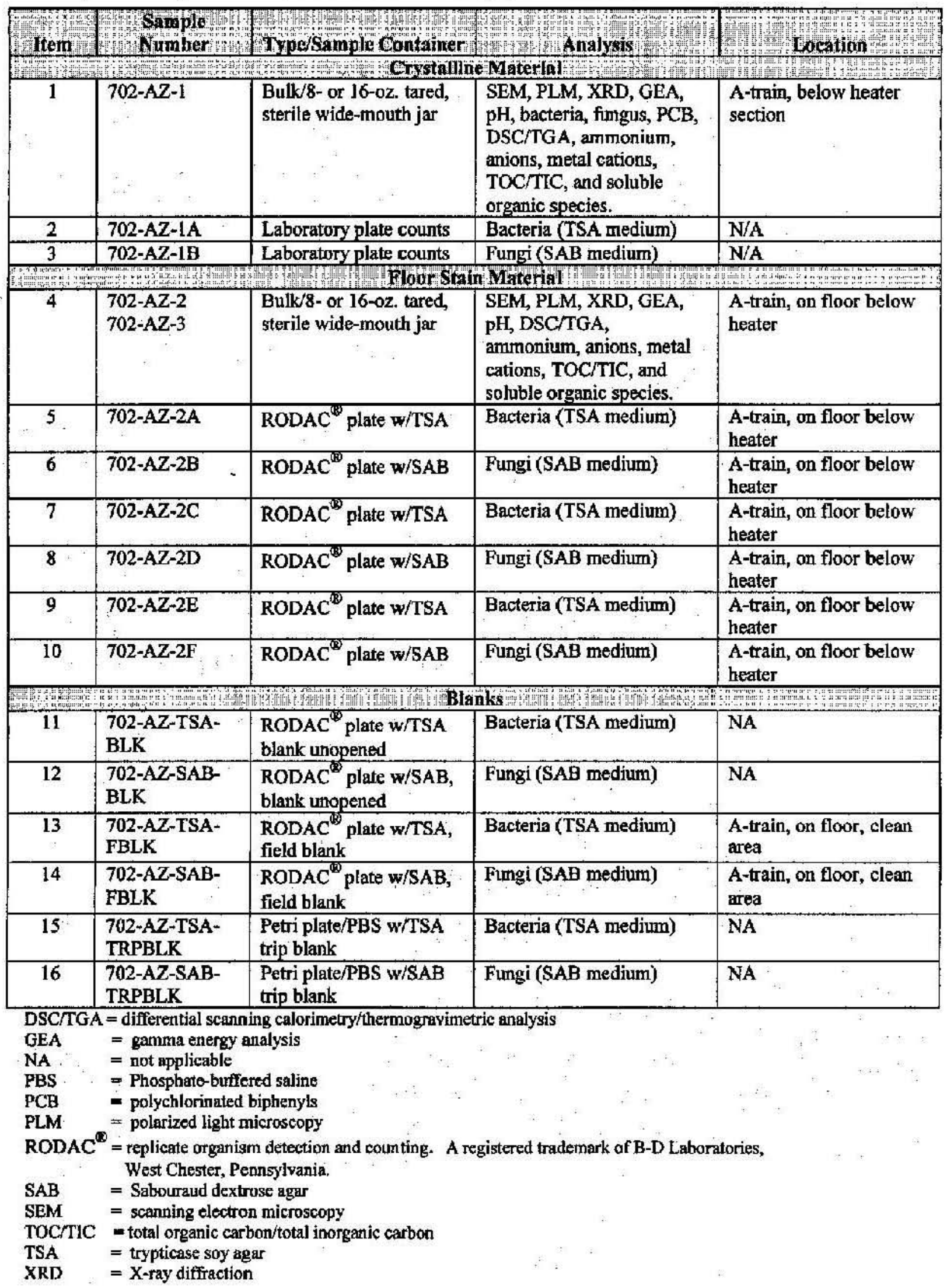


Sample 702-AZ-1 is identified in LABCORE as S06E001025, sample 702-AZ-2 is identified in LABCORE as S06E001026, and the retake of the floor material (702-AZ-3) and subsequent blending with the S06E001026 floor material is identified in LABCORE as SO6E001042. The section of pipe did not have a field sample number and is tracked in LABCORE as S06E001029.

\subsection{SAMPLE LOCATION}

Figure 4 shows the sample location for the external ventilation duct crystalline material, S06E001025. Figure 5 shows the sample location for the floor material, S06E001026. The retake of the floor sample, 702-AZ-3 was from the same location identified in Figure 5. Figure 6 shows the sample locations for the microbial surface enumeration using RODAC ${ }^{1}$ plates. Figure 7 shows the uncontaminated concrete surface control area for the microbiological analysis.

\section{Figure 4. Sample location for External Ventilation} Duct Crystalline Material.

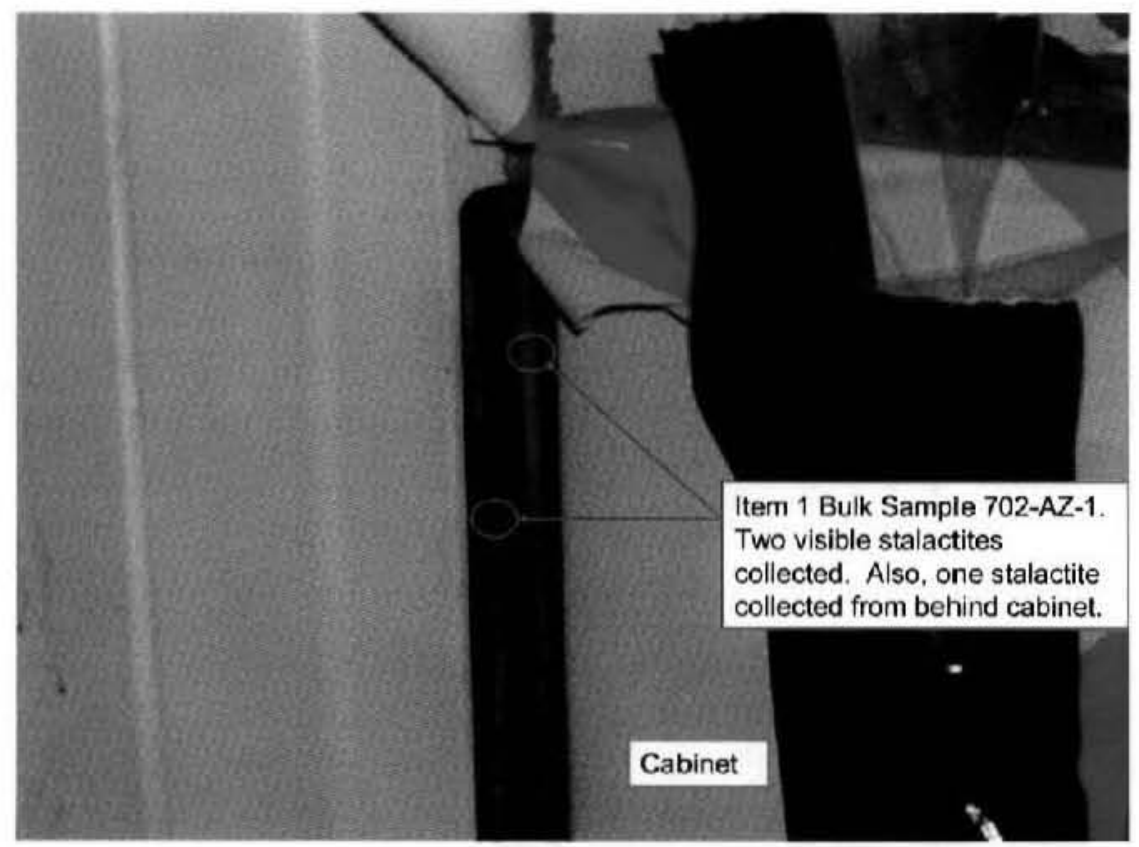

${ }^{1}$ RODAC is a registered trademark of B-D Laboratories, West Chester, Pennsylvania. 
Figure 5. Sample Location for Floor Material.

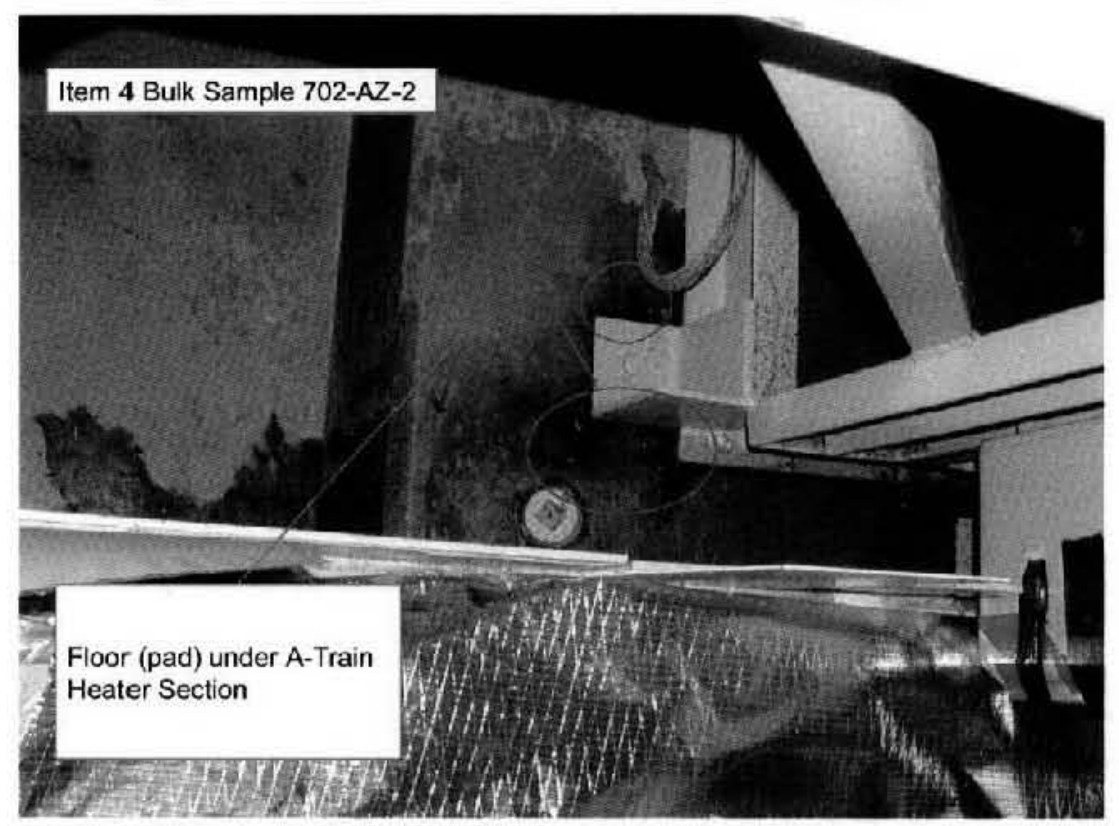

Figure 6. Microbiological Surface Sample Locations.

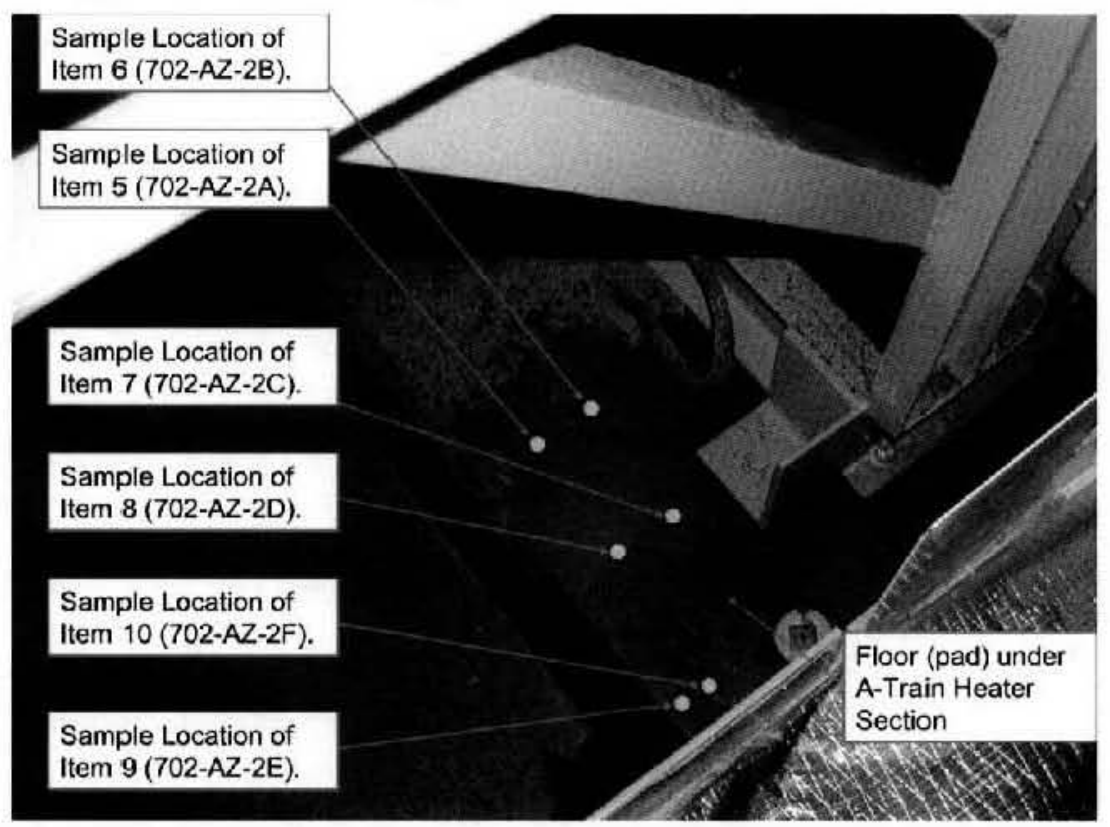


Figure 7. Uncontaminated Concrete Microbiological Control Sample Location.

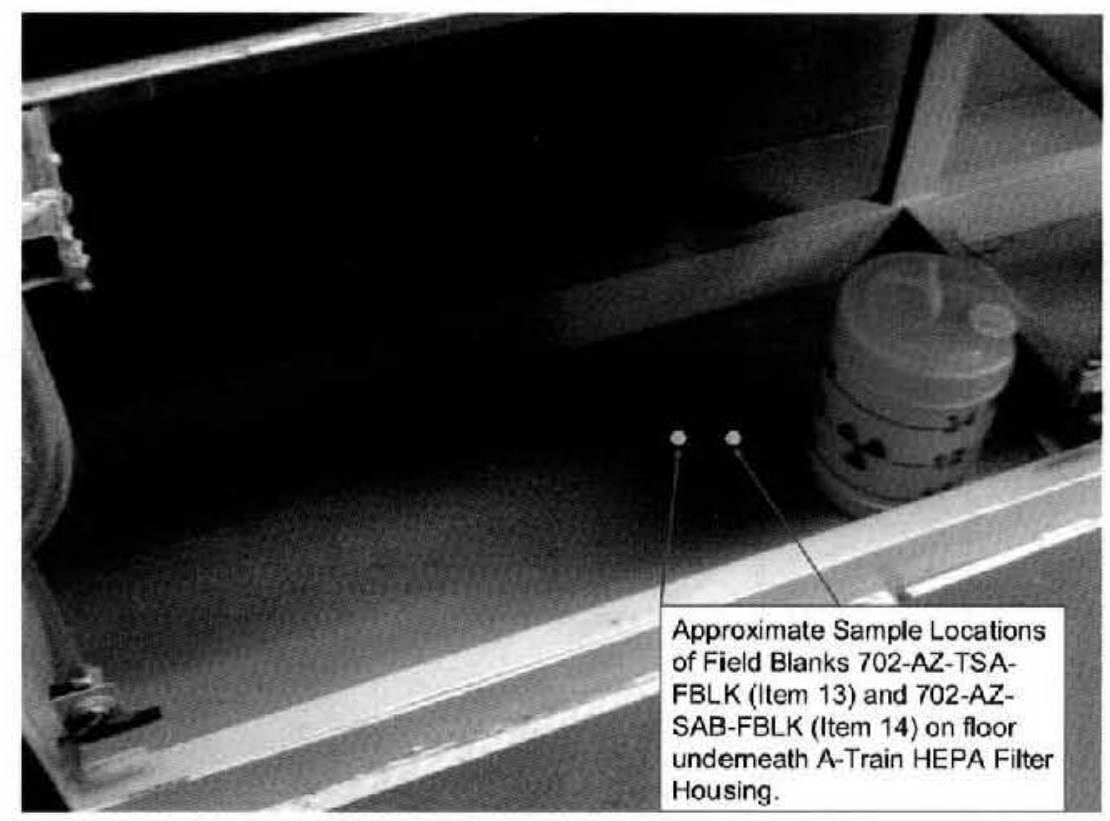

2. ANALYSES RESULTS

\subsection{MICROBIOLOGICAL ANALYSES}

\subsubsection{Surface Enumeration}

Microbial enumeration of the floor stain material was accomplished by pressing against the test area a RODAC ${ }^{18}$ plate containing trypticase soy agar (general heterotrophic bacterial agar) (Appendix C-1) and a RODAC ${ }^{(\mathbb{Q})}$ plate containing Sabouraud's dextrose agar (general heterotrophic fungi agar) (Appendix C-2). The plates were incubated at room temperature and counted over 5 days and the ending microbial growth reported. There was no confluent growth observed early in the incubation on the RODAC ${ }^{\mathbb{R}}$ places. The results are presented in Table 4.

\subsubsection{Dilution Plate Counts}

A known mass of sample was weighed from S06E001025 (crystalline material) and S06E001026 (floor material) and solubilized in $2 \mathrm{~mL}$ of sterile phosphate buffered saline (PBS)

(Appendix C-3). Tenfold dilutions beginning with $10^{1}$ and up to $10^{3}$ were made from the solubilized material and plated on TSA (Appendix C-4) and SAB (Appendix C-5) agar. A spread plate technique was used to cover the agar surface. The plates were incubated at room temperature and counted over 5 days and the ending microbial growth reported. Table 5 presents the results from the 702-AZ material. As an indicator of microbial abundance in soil, a random sample was generated from soil gathered from the 300 Area near Building 331 and is identified as "soil sample" in Table 5. 
Table 4. RODAC Plate Results.

\begin{tabular}{|c|c|c|c|}
\hline Sample Number & Agar Type & $\begin{array}{c}\text { Colony-Forming Units } \\
\text { per Plate" }\end{array}$ & $\mathrm{dpm}^{\mathrm{b}}$ \\
\hline 702-AZ-2A & TSA & 88 & 500 \\
\hline $702-A Z-2 B$ & $\mathrm{SAB}$ & 41 & 350 \\
\hline $702-\mathrm{AZ}-2 \mathrm{C}$ & TSA & 82 & 1,100 \\
\hline 702-AZ-2D & SAB & 21 & 800 \\
\hline 702-AZ-2E & TSA & 68 & 1,500 \\
\hline 702-AZ-2F & SAB & 27 & 1,000 \\
\hline 702-AZ-TSA-BLK ${ }^{\mathrm{C}}$ & TSA & No growth & $\mathrm{NA}^{\text {d }}$ \\
\hline 702-AZ-SAB-BLK ${ }^{c}$ & SAB & No growth & NA \\
\hline 702-AZ-TSA-FBLK ${ }^{\mathrm{C}}$ & ISA & 110 & $<50$ \\
\hline 702-AZ-SAB-FBLK ${ }^{2}$ & $\mathrm{SAB}$ & 71 & $<50$ \\
\hline 702-AZ-TSA-TRPBLK! & TSA & No growth & NA \\
\hline 702-AZ-SAB-TRPBLK ${ }^{f}$ & SAB & No growth & NA \\
\hline
\end{tabular}

Agar area is 3.97 square inches.

${ }^{b} \mathrm{dpm}=$ disintegrations per minute (The associated dpm readings is for relative indicators only. The counts were taken using a Geiger-Mueller (GM) counter through the boltom of the RODAC ${ }^{*}$ plate.).

${ }^{6} \mathrm{BLK}=\mathrm{Blank}$ control, unopened RODAC ${ }^{\Phi}$ plate.

${ }^{\mathrm{N} A}=$ not applicable.

FBLK Field blank, contact plate from adjacent non-stained area, see Figure 7.

${ }^{i}$ TRPBLK = Trip blank, opened but not contacted RODAC ${ }^{6}$ plate.

Table 5. Microblal Plate Count Results.

\begin{tabular}{|l|c|l|}
\hline \multicolumn{3}{|c|}{ S06E001025 (crystalline material) } \\
\hline Growth Medium & Sample Mass & CFU/g \\
\hline TSA for heterotrophic bacteria & 0.145 & $1.5 \mathrm{E}+03$ \\
\hline SAB for heterotrophic fungi & 0.145 & No growth \\
\hline \multicolumn{3}{|c|}{ S06E001026 (floor materia) } \\
\hline TSA for heterotrophic bacteria & 0.132 & $1.1 \mathrm{E}+03$ \\
\hline SAB for heterotrophic fungi & 0.132 & $5.9 \mathrm{E}+02$ \\
\hline \multicolumn{3}{|c|}{ 300 Area Sail Sample } \\
\hline TSA for heterotrophic bacteria & 0.2 & $3.5 \mathrm{E}+04$ \\
\hline SAB for heterotrophic fungi & 0.2 & $8.9 \mathrm{E}+03$ \\
\hline
\end{tabular}

\subsection{CHEMiCAL ANALYSES}

\subsubsection{Material from 702AZ A-Train}

The results of the initial chemical testing performed on samples of the external ventilation duct crystalline material and the floor substance are presented in Table 6 . These analyses were carried out before the floor substance was resampled (702-AZ-3) and blended with the 702-AZ-2 initial floor sample. The resample and blending allowed enough floor material to be subjected to all requested chemical analysis at the best analytical method detection level possible. Table 7 presents the secondary chemical results of the crystalline and blended materials. Where duplicate analysis was performed, the average values are presented. The complete analytical results are included in Appendix D. Only results found above detection limits are reported in Table 7. 
Table 6. Initial Analytical Results for SO6E001025 (crystalline material) and SO6E001026 (floor material).

\begin{tabular}{|c|c|c|c|c|}
\hline \multirow{2}{*}{$\begin{array}{c}\text { Analysis } \\
\end{array}$} & \multicolumn{4}{|c|}{ Sample } \\
\hline & \multicolumn{2}{|c|}{ \$06E001025 } & \multicolumn{2}{|c|}{ SOSE001026 } \\
\hline & ${ }^{137} \mathrm{Cs}$ & $\begin{array}{l}0.338 \mu \mathrm{Ci} / \mathrm{g} \\
(3.98 \%)\end{array}$ & ${ }^{137} \mathrm{Cs}$ & $\begin{array}{l}0.638 \mu \mathrm{Ci} / \mathrm{g} \\
(3.99 \%)\end{array}$ \\
\hline $\begin{array}{l}\text { SEM with energy } \\
\text { dispersive } X \text {-ray } \\
\text { spectroscopy (EDS) }\end{array}$ & \multicolumn{2}{|c|}{$\mathrm{NH}_{4} \mathrm{NO}_{3}$} & \multicolumn{2}{|c|}{$\begin{array}{l}\text { Mixture of } \mathrm{NH}_{4} \mathrm{NO}_{3} \text { and } \mathrm{NaNO}_{3} \text { with } \\
\text { organic (carbon rich) coating. }\end{array}$} \\
\hline PLM & \multicolumn{2}{|c|}{ Not done (see text) } & \multicolumn{2}{|c|}{$\begin{array}{l}\mathrm{NaNO}_{3}, \mathrm{NaNO}_{2} \text {, and/or } \mathrm{NH}_{4} \mathrm{NO}_{3} \\
\text { along with organic material. }\end{array}$} \\
\hline XRD & \multicolumn{2}{|c|}{$\mathrm{NH}_{4} \mathrm{NO}_{3}$} & \multicolumn{2}{|c|}{$\begin{array}{l}\mathrm{NH}_{4} \mathrm{NO}_{3}, \mathrm{NaNO}_{3} \text { and } \mathrm{a} \\
\text { noncrystalline phase }\end{array}$} \\
\hline Solid pH & \multicolumn{2}{|l|}{3.94} & \multicolumn{2}{|l|}{4.68} \\
\hline PCB screen & \multicolumn{2}{|c|}{ None detected } & \multicolumn{2}{|c|}{ None detected } \\
\hline
\end{tabular}

As shown in Table 6, the only radionuclide that was found in both samples, using a gamma energy analysis (GEA) scan, was ${ }^{137} \mathrm{Cs}$. All other radionuclides were at the less than detect level. The scanning electron microscope (SEM) using dispersive $\mathrm{X}$-ray spectroscopy (EDS) indicated that the crystalline material was essentially ammonium nitrate. The floor material was found to be primarily a mixture of ammonium nitrate, sodium nitrate, and an organic coating with minor amounts of chlorine, calcium and iron. The X-ray diffraction (XRD) analysis confirmed the SEM results. The polarized light microscopy (PLM) for S06E001025 (crystalline material) was not performed. This was because the diagnostic PLM test for ammonium nitrate involves heating the sample and observing the sample optically as the sample cools. Currently, the PLM procedure for analysis of radiologically contaminated samples requires a radiation survey before it is brought out of the hood to the laboratory bench. The time that it would take to affect a radiation survey would have allowed the sample to cool before it could be examined on the PLM. Since the PLM would only reconfirm the findings of the XRD and the SEM for S06E001025, it was decided to only examine S06E001026 (floor material) by PLM. Analysis of S06E001026 by PLM was performed because of the more complex nature of the sample including the apparent high organic content based on the SEM/EDS results.

The crystalline material and floor substance are both mildly acidic with $\mathrm{pH}$ of 3.93 and 4.68 , respectively. For comparison purposes, a 0.1 molar (moles/L) ammonium nitrate solution has a pH of 5.43 (The Merck Index, an Encyclopedia of Chemicals, Drugs, and Biologicals, Windholz et al. 1983).

For more complete descriptions of the analyses carried out with the SEM/EDS, PLM, XRD, see Appendixes $\mathrm{E}, \mathrm{F}$, and $\mathrm{G}$, respectively. 
RPP-RPT-31293, Rev. 0

Table 7. Analysis Results of SO6E001025 (crystalline material) and SO6E001042 (blended floor sample).

\begin{tabular}{|c|c|c|}
\hline \multirow[b]{2}{*}{ Analysis (units) } & \multicolumn{2}{|c|}{ Sample } \\
\hline & S06C001025 & S06E001042 \\
\hline $\mathrm{DSC}, \mathrm{J} / \mathrm{g}$ & $9.73 \mathrm{E}+02$ & $1.16 \mathrm{E}+03$ \\
\hline \% water" & 100 & 79.7 \\
\hline $\mathrm{TOC}, \mu \mathrm{g} / \mathrm{g}$ & $2.35 \mathrm{E}+04$ & $8.43 \mathrm{E}+04$ \\
\hline TIC, $\mathrm{Hg} / \mathrm{g}$ & 254 & 203 \\
\hline Ahuminum, $\mu \mathrm{g} / \mathrm{g}$ & $\mathrm{ND}^{\mathrm{b}}$ & 74.5 \\
\hline Barium, $\mu \mathrm{g} / \mathrm{g}$ & 7.29 & 15.8 \\
\hline Boron, $\mu \mathrm{g} / \mathrm{g}$ & 519 & $1.22 \mathrm{E}+03$ \\
\hline Calcium, $\mu \mathrm{g} / \mathrm{g}$ & $1.34 \mathrm{E}+03$ & $5.10 \mathrm{E}+03$ \\
\hline Chromium, $\mu \mathrm{g} / \mathrm{g}$ & $12.0^{c}$ & 4.82 \\
\hline Copper, $\mu \mathrm{g} / \mathrm{g}$ & 13.8 & 31.2 \\
\hline Europium, $\mu \mathrm{g} / \mathrm{g}$ & 0.353 & 1.14 \\
\hline Iron, $\mu \mathrm{g} / \mathrm{g}$ & 30.0 & 985 \\
\hline Lead, $\mu \mathrm{g} / \mathrm{g}$ & ND & 10.4 \\
\hline Lithium, $\mu \mathrm{g} / \mathrm{g}$ & ND & 2.01 \\
\hline Magnesium, $4 \mathrm{~g} / \mathrm{g}$ & $9.96 \mathrm{E}+02$ & $1.99 \mathrm{E}+03$ \\
\hline Manganese, $\mu \mathrm{g} / \mathrm{g}$ & 3.93 & 21.3 \\
\hline Molybdernum, $\mu \mathrm{g} / \mathrm{g}$ & 2.48 & 2.98 \\
\hline Phosphorus, $\mu \mathrm{g} / \mathrm{g}$ & 409 & 879 \\
\hline Potassium, $\mu \mathrm{g} / \mathrm{g}$ & $1.40 \mathrm{E}+03$ & $2.20 \mathrm{E}+03$ \\
\hline Silicon, $\mu \mathrm{g} / \mathrm{g}$ & 12.8 & 128 \\
\hline Sodium, $\mu \mathrm{g} / \mathrm{g}$ & $3.46 \mathrm{E}+04$ & $3.58 \mathrm{E}+04$ \\
\hline Strontium, $\mu \mathrm{g} / \mathrm{g}$ & 1.62 & 6.58 \\
\hline Sulfur, $\mu g^{\prime} g$ & 362 & 976 \\
\hline Thorium, $\mu \mathrm{g} / \mathrm{g}$ & ND & 1.80 \\
\hline Titanium, $\mu g / g$ & ND & 8.40 \\
\hline Uranium, $\mu \mathrm{g} / \mathrm{g}$ & 7.40 & 10.4 \\
\hline Zinc, $\mu \mathrm{g} / \mathrm{g}$ & 27.5 & 146 \\
\hline Zirconium & ND & 0.407 \\
\hline Ammonium ion, $\mu \mathrm{g} / \mathrm{g}$ & $1.81 \mathrm{E}+05$ & $1.38 \mathrm{E}+05$ \\
\hline Nitrate, $\mu \mathrm{g} / g$ & $6.16 \mathrm{E}+05$ & $4.68 \mathrm{E}+05$ \\
\hline Acetate, $\mu \mathrm{g} / \mathrm{g}$ & ND & $4.05 \mathrm{E}+3$ \\
\hline Chloride, $\mu \mathrm{g} / \mathrm{g}$ & $1.71 \mathrm{E}+03$ & $3.73 \mathrm{E}+03$ \\
\hline Glycolate, $\mu \mathrm{g} / \mathrm{g}$ & ND & $4.76 \mathrm{E}+03$ \\
\hline Sulfate, $\mu \mathrm{g} / \mathrm{g}$ & ND & $1.94 \mathrm{E}+03$ \\
\hline $\begin{array}{l}\text { Butylbenzylphthalate, } \\
\mu \mathrm{g} / \mathrm{g}\end{array}$ & $3.36 \mathrm{E}+03^{d}$ & $2.73 \mathrm{E}+03^{\mathrm{d}}$ \\
\hline Di-n-butylphthalate, $\mu \mathrm{g} / \mathrm{kg}$ & $8.31 \mathrm{E}+03^{\mathrm{d}}$ & ND \\
\hline Di-n-octylphthalate, $\mu \mathrm{g} / \mathrm{kg}$ & $3.15 E+03$ & $3.48 \mathrm{E}+03$ \\
\hline
\end{tabular}

$\%$ Water is the \% weight loss at $250^{\circ} \mathrm{C}$ from the TGA scan (see Appendix D). In this case other volatile phases are responsible for this weight loss.

Less than detection limit.

'The relative percent difference of the result and duplicate is $>127 \%$ because the duplicate was found to be below the detection limit. Only the result is reported.

d Blank contaminated; the blank contained more than the sample.

Due to the energetics found with the differential scanning calorimetry (DSC) analysis reported in Table 7 for both the crystalline and floor materials, it was decided to compare DSC scans of analytical-grade ammonium nitrate and a mixture of analytical-grade ammonium nitrate with 


\section{RPP-RPT-31293, Rev. 0}

$0.2 \mathrm{wt} \%$ chloride. Additionally, the DSC is normally carried out under an inert gas atmosphere, which would lower the energetics if oxygen in air enters into the thermally induced chemical reactions. Therefore, a DSC analysis was carried out on both the crystalline material and floor material under an air purge. The residues from the DSC analyses were characterized using SEM/EDS and the results reported in Appendix E. Table 8 presents all DSC results (see Appendix D for the DSC scans).

Table 8. Results of Differential Scanning Calorimetry.

\begin{tabular}{|l|c|c|c|}
\hline \multicolumn{1}{c|}{ Sample } & Atmosphere & $\begin{array}{c}\text { Activation } \\
\text { Temperature ( }\end{array}$ & E) \\
\hline $\begin{array}{l}\text { SO6E001025 } \\
\text { (crystalline material) }\end{array}$ & Nitrogen & 179 & 973 \\
\hline $\begin{array}{l}\text { SO6E001042 } \\
\text { (floor materia) }\end{array}$ & Nitrogen & 213 & 1,160 \\
\hline $\begin{array}{l}\text { SO6E001043 } \\
\text { (ammonium nitrate) }\end{array}$ & Nitrogen & 269 & 302 \\
\hline $\begin{array}{l}\text { SO6E001044 } \\
\text { (ammonium nitrate plus } \\
0.2 \text { wt\% chloride) }\end{array}$ & Nitrogen & 234 & 504 \\
\hline $\begin{array}{l}\text { SO6E001025 } \\
\text { (crystalline material) }\end{array}$ & Air & 171 & 523 \\
\hline $\begin{array}{l}\text { SO6E001042 } \\
\text { (flons material) }\end{array}$ & Air & 192 & 1,867 \\
\hline
\end{tabular}

The semivolatile organic carbon analysis gas chromatographic traces of SO6E001025 and SO6E001042 are presented in Appendix D. Note the rise in baseline for both chromatographs. This series of peaks in these chromatograms is typically observed in mixtures of hydrocarbons. Based on the averaged mass spectral data, it appears that the "hump". exhibited in the chromatogram resembles a petroleum-based product such as an oil or grease.

\subsubsection{Analyses of Material Internal to Pipe Segment}

During the tie-in of a new pipeline between the 702-AZ ventilation system seal pot and the new AZ-301 condensate receiver tank, some unknown material was encountered internal to the old pipe section removed during the installation. The pipe section was sent to 222-S Laboratory for analyses under RPP-PLAN-28509.

Sample S06E001029 consisted of the small amount of material that was recovered by scraping the inside of the pipe. Due to the paucity of material, the only analyses that was possible was SEM/EDS. The SEM/EDS indicated carbon-rich material and material consistent with zeolite. Appendix $\mathrm{H}$ gives a complete description of the analysis.

\section{CONCLUSIONS AND RECOMMENDATIONS}

\subsection{MICROBIOLOGICAL ANALYSIS}

The objective of the microbiological characterization was to determine if the floor stain or the crystalline material might be a result of microbial biofilm growth and thus of potential concern to 
workers. Prior to conducting the work, the criteria for concern was defined by microbiologists as a microbial population approaching or exceeding $10^{6}$ colony-forming units (CFU)/g on dilution plates, or confluent growth observed early in the incubation on either dilution plates or RODAC ${ }^{\mathbb{B}}$ contact plates.

The floor stains are not a result of microbial biofilm formation. RODAC ${ }^{\mathbb{E}}$ contact plate results show that the non-stained floor area has the highest heterotrophic bacterial and fungal population as compared to the three floor stain areas tested (Figure 8). A reverse correlation appears to exist between the radioactivity and the microbial population (Figures 8 and 9). The non-stained area with lowest radioactivity ( $<50 \mathrm{dpm} /$ plate) has the highest microbial counts; while the stained areas, with radioactivity range from 350 to $1500 \mathrm{dpm} /$ plate, all have lower microbial densities. It is possible that the chemical and/or radiation properties of the floor stain inhibit the number of cultured microbes.

Figure 8. Results of Surface Enumeration by Contact Plate.

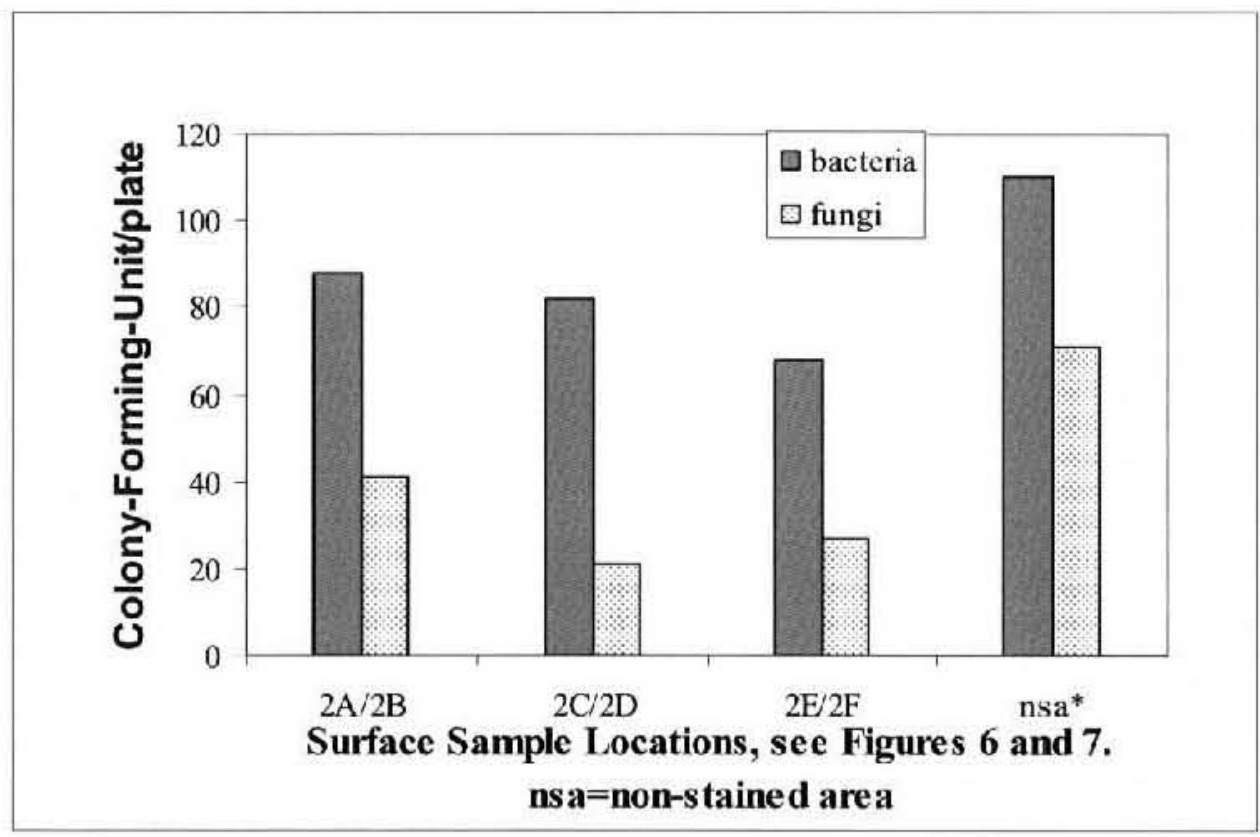

Microbial enumeration of both solid materials (crystalline formation and brownish-black material on the floor) by dilution plate counts indicates that the number of cultured microbes was approximately 1000 times lower than the predefined criteria of concern, and approximately 10 times lower than the control soil sample (Figure 10). While floor material harbors low concentrations of both bacteria and fungi, no fungal growth was found in the crystalline material.

In conclusion, as expected, the samples contained bacteria and/or fungi. However, the number of culturable heterotrophic bacteria and fungi in the samples were low and far below the densities expected for a microbial biofilm. Thus the floor stain and crystalline material are not of concern with respect to a potential microbiological hazard. 
RPP-RPT-31293, Rev. 0

Figure 9. Radioactivity (dpm) in Contact Plate.

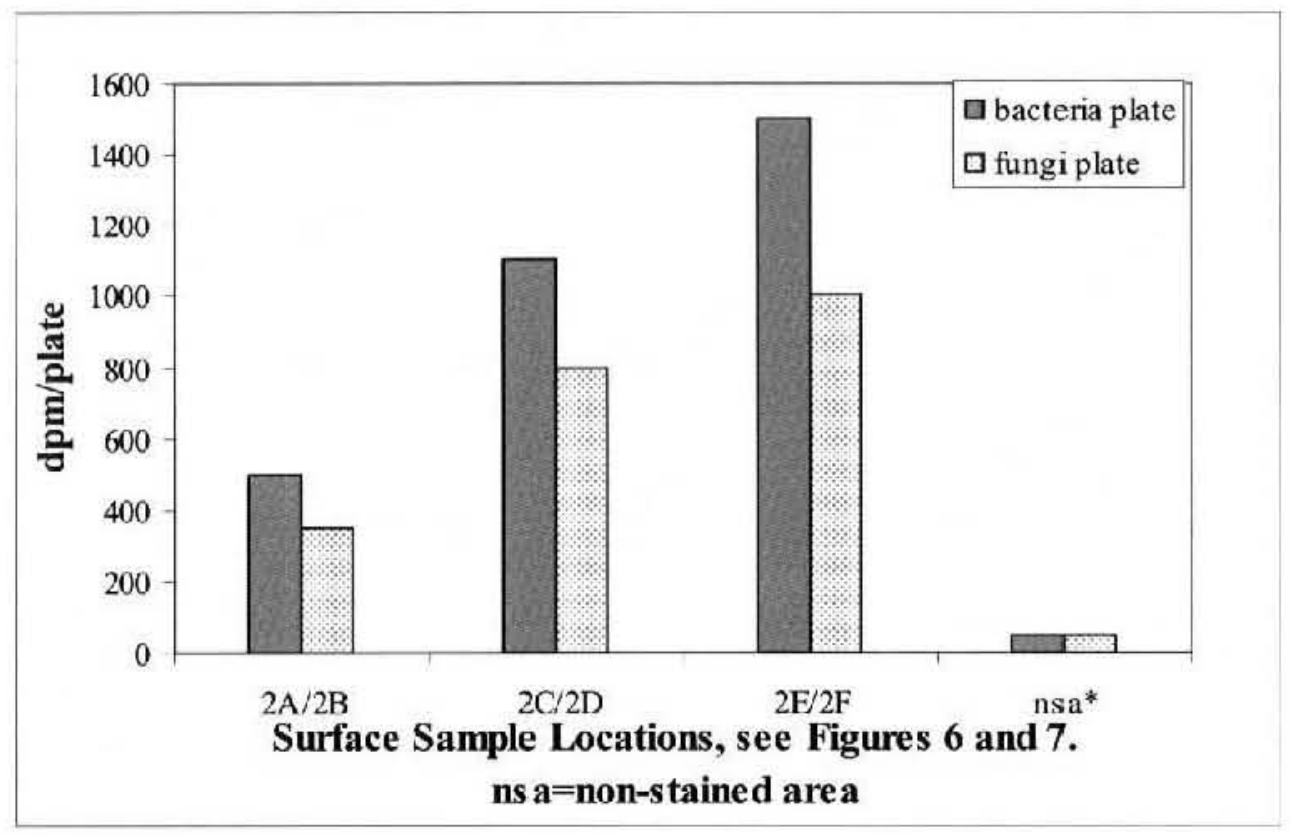

Figure 10. Microbial Population in Solid Materials by Dilution Plate Counts.

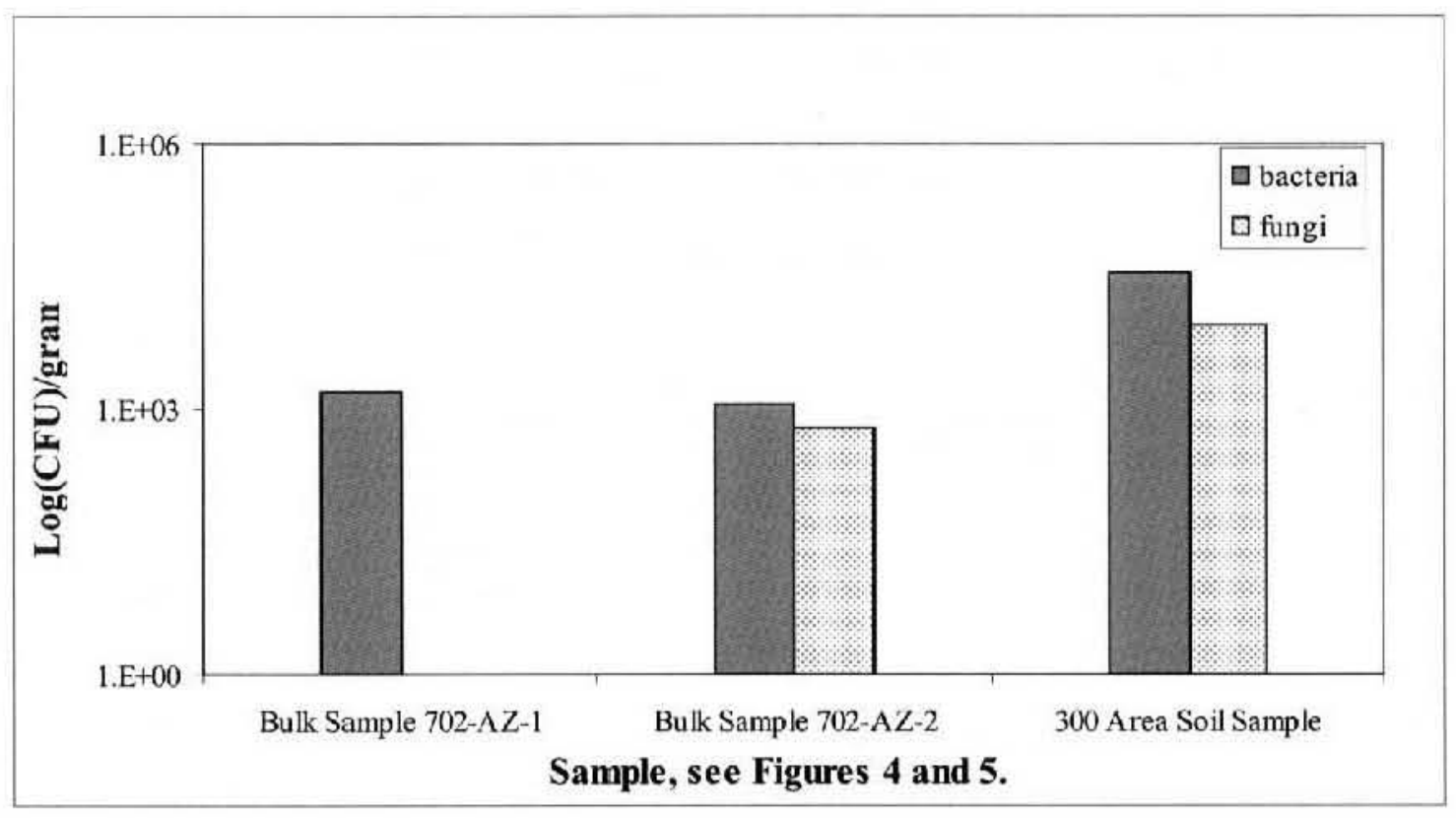




\section{RPP-RPT-31293, Rev. 0}

\subsection{CHEMICAL ANALYSIS}

The samples SO6E001025 and SO6E001042 had significant levels of total organic carbon at $2.35 \mathrm{E}+04 \mu \mathrm{g} / \mathrm{g}$ and $8.43 \mathrm{E}+04 \mu \mathrm{g} / \mathrm{g}$, respectively. The organics were indicated in the gas chromatographic trace as a petroleum-based product such as oil or grease. This coupled with the ammonium nitrate concentrations of $1.81 \mathrm{E}+05 \mu \mathrm{g} / \mathrm{g}$ (SO6E001025) and $1.38 \mathrm{E}+05 \mu \mathrm{g} / \mathrm{g}$ (SO6E001042) may well act as an accelerant during periods of high temperature excursions. This is underscored by the DSC temperature/energy differences of pure ammonium nitrate and ammonium nitrate plus $0.2 \mathrm{wt} \%$ chloride (both had higher activation temperatures and lower energies), as compared to the samples collected from the 702-AZ Filter Room A external ventilation duct and floor. Also, the DSCs of the 702-AZ A-train samples were energetic enough to expel residue produced by the chemical reactions occurring in the measurement containers from the container vent ports.

Therefore, clean up and disposal of the ammonium nitrate external to the ventilation duct in Filter Room A needs to be carried out with caution. Although ammonium nitrate is considered a very stable sait, when allowed to heat up to temperatures on the order of $200^{\circ} \mathrm{C}$ to $230^{\circ} \mathrm{C}$, exothermic decomposition occurs (Encyclopedia of Chemical Technology, Kirk-Othmer 1992). Additional work is recommended to validate the chemical composition of any ammoniumnitrate-bearing materials accumulating intemal to the ventilation duct, particularly in the heater section where temperatures are high.

\subsection{PATH FORWARD FOR CLEANING AND DISPOSING OF EXTERNAL VENT DUCT AND FLOOR MATERIALS}

The crystalline and floor materials are water soluble. The deposits can be collected in the solid phase and added to a carboy filled with water to dissolve the materials. The solution can then be pumped back into the condensate collection system and returned to the tank farm. This would eliminate the potential reactivity of the bulk of the material if it were to be disposed of in a waste drum.

The residue remaining on the ventilation duct surfaces and floor area after recovering the bulk of the materials can be further cleaned using damp rags. If practical, triple rinse the used rags in separate batches of clean water to extract any residual ammonium nitrate from the rags prior to disposal as solid waste. The rinse water can be pumped back to the condensate collection system for transfer back to the tank farm.

Before the clean up commences, PPE needs to be selected to protect against the acidic nature of the solids deposits and the potential for ammonia release when the solids are dissolved in water. Waste designation of the rinsed damp rags should follow the normal process for waste disposal operations. 
RPP-RPT-31293, Rev. 0

\section{REFERENCES}

Kirk-Othmer, 1992, Encyclopedia of Chemical Technology, "Ammonium Nitrate," John Wiley \& Sons, Inc., Hoboken, New Jersey.

PER-2004-2155, "702-AZ Filter Room Arca Posted High Contamination Area," CH2M HILL Hanford Group, Inc., Richland, Washington, dated April 16, 2004.

PER-2004-6139, "702-AZ Filter Rooms Need Radiological Cleanup Efforts," CH2M HILL Hanford Group, Inc., Richland, Washington, dated December 15, 2004.

RPP-PLAN-28509, 2006, Sampling and Analysis Plan for Building 241702-AZ A Train, Rev. 1, CH2M HILL Hanford Group, Inc., Richland, Washington.

RPP-15127, 2005, System Design Description for AY and AZ Tank Farm Primary Ventilation System (DSA-Based), Rev. 2, CH2M HILL Hanford Group, Inc., Richland, Washington.

Windholz, M., S. Budavari, R. F. Blumetti, and E. S. Otterbein (Editors), 1983, The Merck Index, an Encyclopedia of Chemicals, Drugs, and Biologicals, Merck \& Co. Inc., Whitehouse Station, New Jersey. 
Page 25 of 162 of DA04063678

RPP-RPT-31293, Rev. 0

APPENDIX A

FIELD SAMPLING REPORTS FROM DURATEK 


\section{$\underset{\text { ENERGYSOLUTIONS }}{\text { RPP-RPT-31293, Reratek }}$}

July 5,2006

MAW-06-4426

R. D. Gustayson

CH2M Hill Hanford S5-25

Post Office Box 1500

Richland, Washington 99354-1500

Dear Mr. Gustavson:

702-AZ VENTILATION BUILDING - BIOLOGICAL SAMPLES - 200 EAST AREA

Duratek Federal Services, Inc. completed the subject sampling event on May 25, 2006. Attached for your records are copies of the Chain of Custody, sampling logbook entries and other associated documeritation pertinent to the sampling tasks performed.

Thank you for the opportunity to be of service. If there are any questions, please contact me at 308-5721.

Very truly yours,

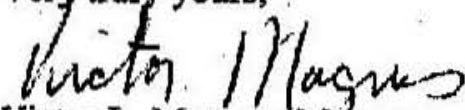

Victor L. Magnus, Monager

Sampling and Well Services

maw

Attachment

DTSNW - V. L. Magnus File/LB

RC6021 
RPP-RPT-31293, Rev. 0

\section{PROJECT FILE CHECKLIST}

SAF\#: S06-051 CUST.PROJ.\#: 502087/FACOLATE: 5/25/06

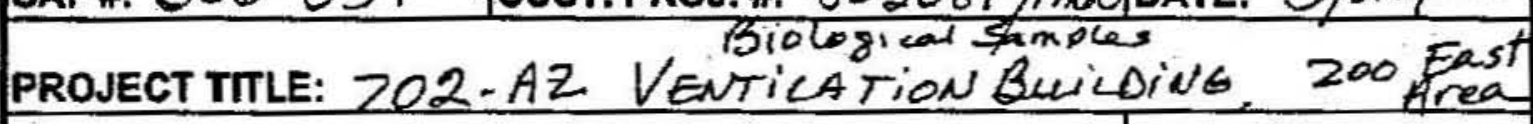
\begin{tabular}{|c|c|}
\hline POSSIBLE ITEMS & $\checkmark$ IF INCLUDED \\
\hline
\end{tabular}

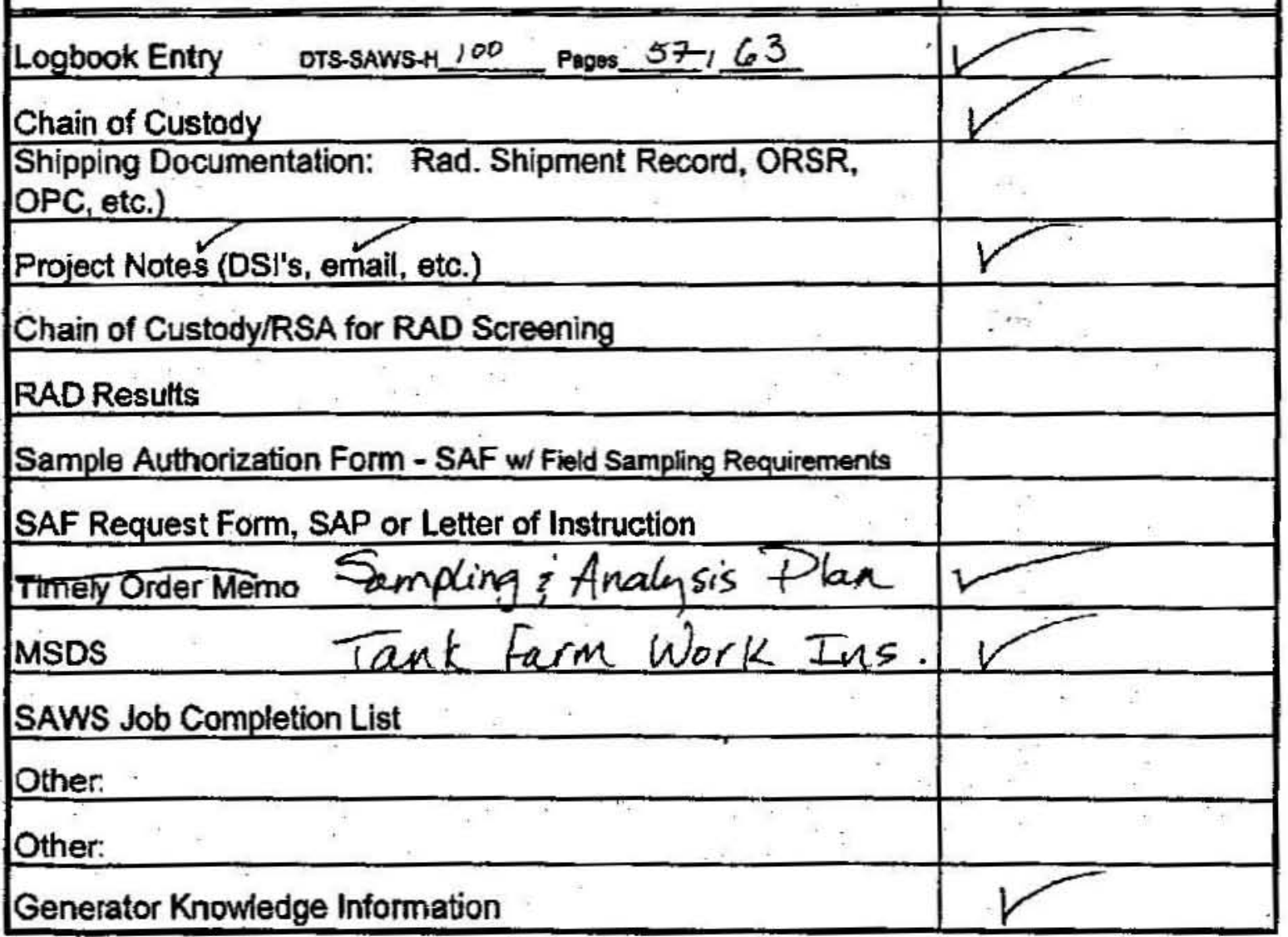

Reviewer: $M . O$. Wolfe

Ready For File (nitial) (maw)

Lotter : 4426 Dale Sent

ADbv Cose RC6O21

Requestoricuslomer: $\frac{R D . \text { Gustauson }}{55-25} 3-5090$ 
RPP-RPT-31293, Rev. 0

Project 702-AZ, A TrAin SAMPLES Notebook-No.DTS-SAW/S-H100

57 Continues from Page-Nane

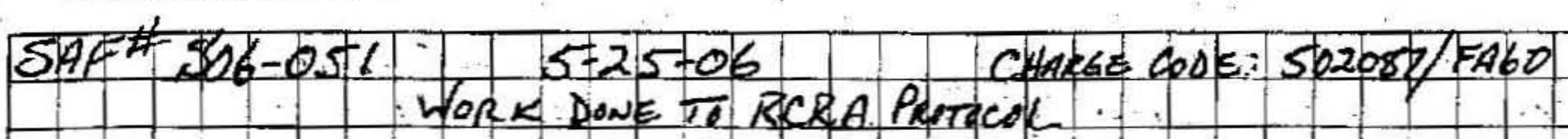

LOCOTION: 702-AZ VENTiLATION Buicbinla, 200 East AREA

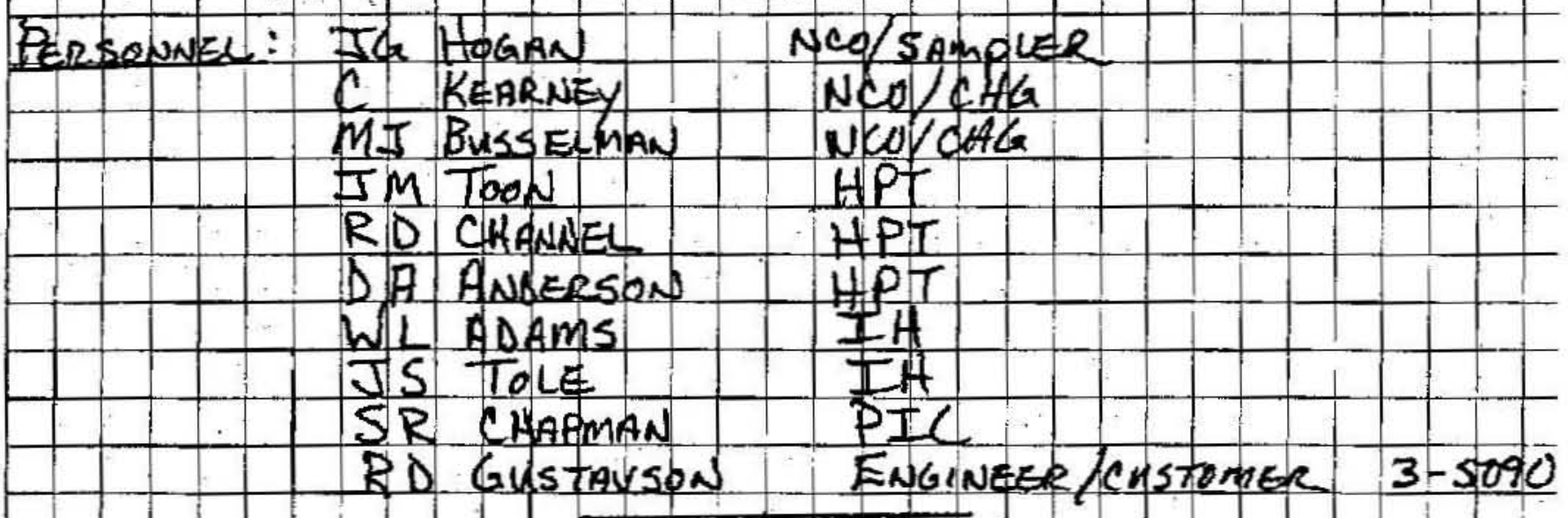

Purpose: Waste characterization

SAP\# XPP-PLAN-28509 RENO RIP WTO-0.22-REV I

WORK PACKAGE: WFO-W0-05-000646

PPE: ONE SET of ANTI-C'S, SCBA, NitRILe GLOUES

SAMPLE EVENT: THE 702-A2 "A "TRAN HAS BEEN OBSERVED TO

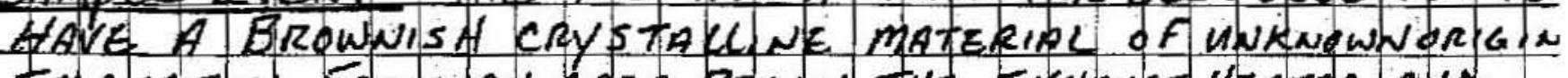
EMANATING FROM AN AREA BELOW THE EXHAUST HEATER AND filter housing as well as a. Brownish-zhack the luke mater IAL ON THE FLOOR IN ClOSE PROXMITY TO THE FILTER HOUSING, ALSO OF UNKNOWN ORIGIN. BOTH MIATERYG IS ARE RADIOACTIVE CONANINATED To HCA LEVELS. THE MATERTALS RPPEAR TO BE A RESULCTOF

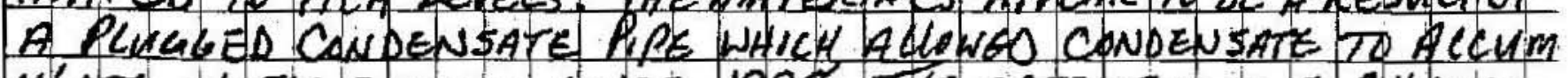
ULATE IN THE SYSTEM SinCE 1998. THE OBJEC TUKE IS TO CHARRCGraze the materials For Both cHemical and Biological ComPONENTS TO ENABLE CLEAN UP AND DECONTAMINATION OF THE FACILITY.

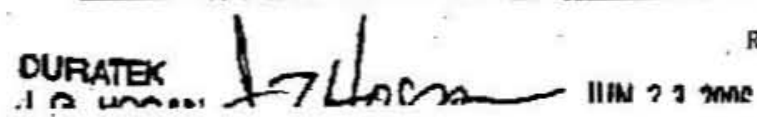

Read and Understood By

A-3 
Continues from Page 5

RPP-RPT-31293, Rev. 0

SAMPLG ME THOD: SAMTLLS OF HE CRYS TACLNE MATERAL WERE COLLETEO BY UISING A STERLLIZEO SCOOP TO CHPOFF PIECE: dF THE HANGING STALACTITES AND PLACING THEM into THE SAMPLE CONTANERS PROVIDEO BY ATL. JHREE OF THE STAL:

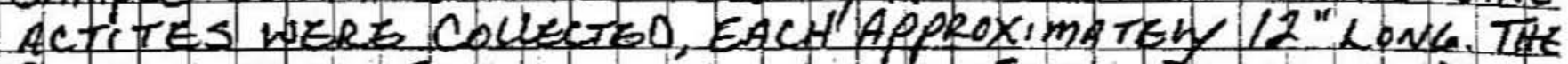

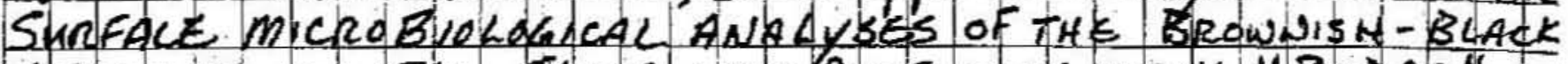

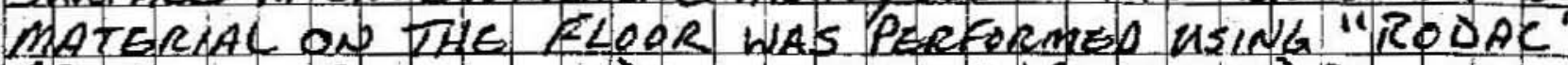
CREPLCATE ORGaNism DETECTION AND COUNTING) PUATES CONTAINING TSA AND SA B. THE PLATES NERE ORENEA AND PRESSEO

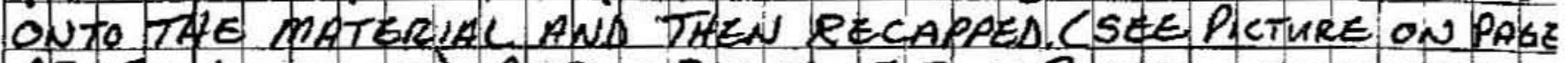
63. Fir Locatrons). A TR p BLANK of Both PLATES Accompanigo THE SAMPLES 20 THE $A A B$. A FIELD BLAWK WAS COCLETEO BY PRESS ING BOTH PLATE TYPES TO THE FLDOR OF A TRAIN AWAY FROMAN

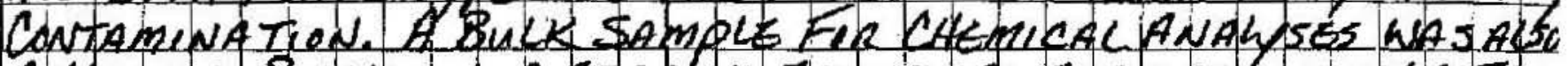
COCAECTEO BV USIUAA STERUE SCOOP TO SCRAPE UP THE TAR

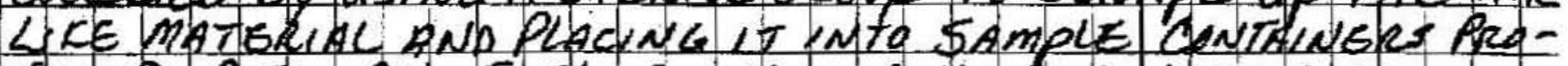
VDEOBVATL. ALL ef tile samples collected here contaminate THE SAMPLE CONTAINECS WER SEALED WITA EvIDENCZ TA PE, SUR VYED FROM THE ZONE BY THE APT ANO PLALED I DOUB LS BAGS ON THE STEP IFEPAD.

TransportatTON: THE SAMPLES WBRE pLACEO WNA COOLER WITHA BLUE ICE ANO THEN SHIPPEO DRECTU TO THE 22J-S LAQ aN

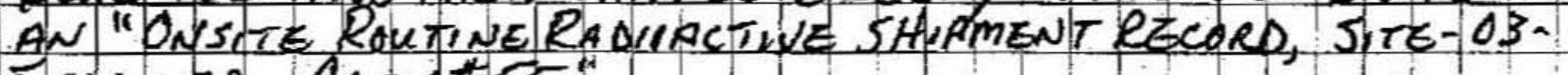
Excepten,

20 . Sample Point: Crystals

Sample Matrix: OTHER

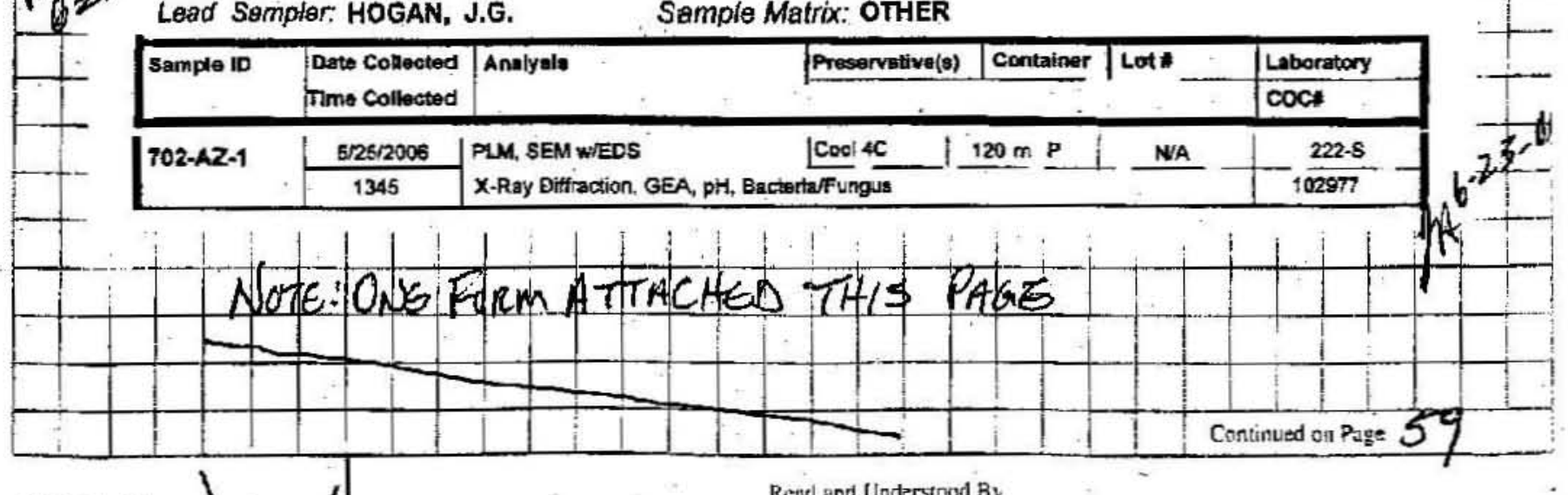

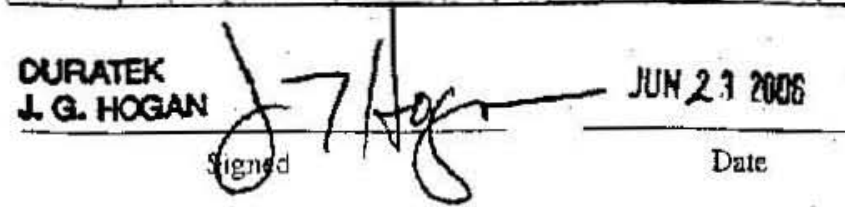
Rend and Understood By 
RPP-RPT-31293, Rev. 0 Project 702 AZ, A TRAIN SAmplES
Continues from Page S8

Notebook No. DTS-SAWS. H100

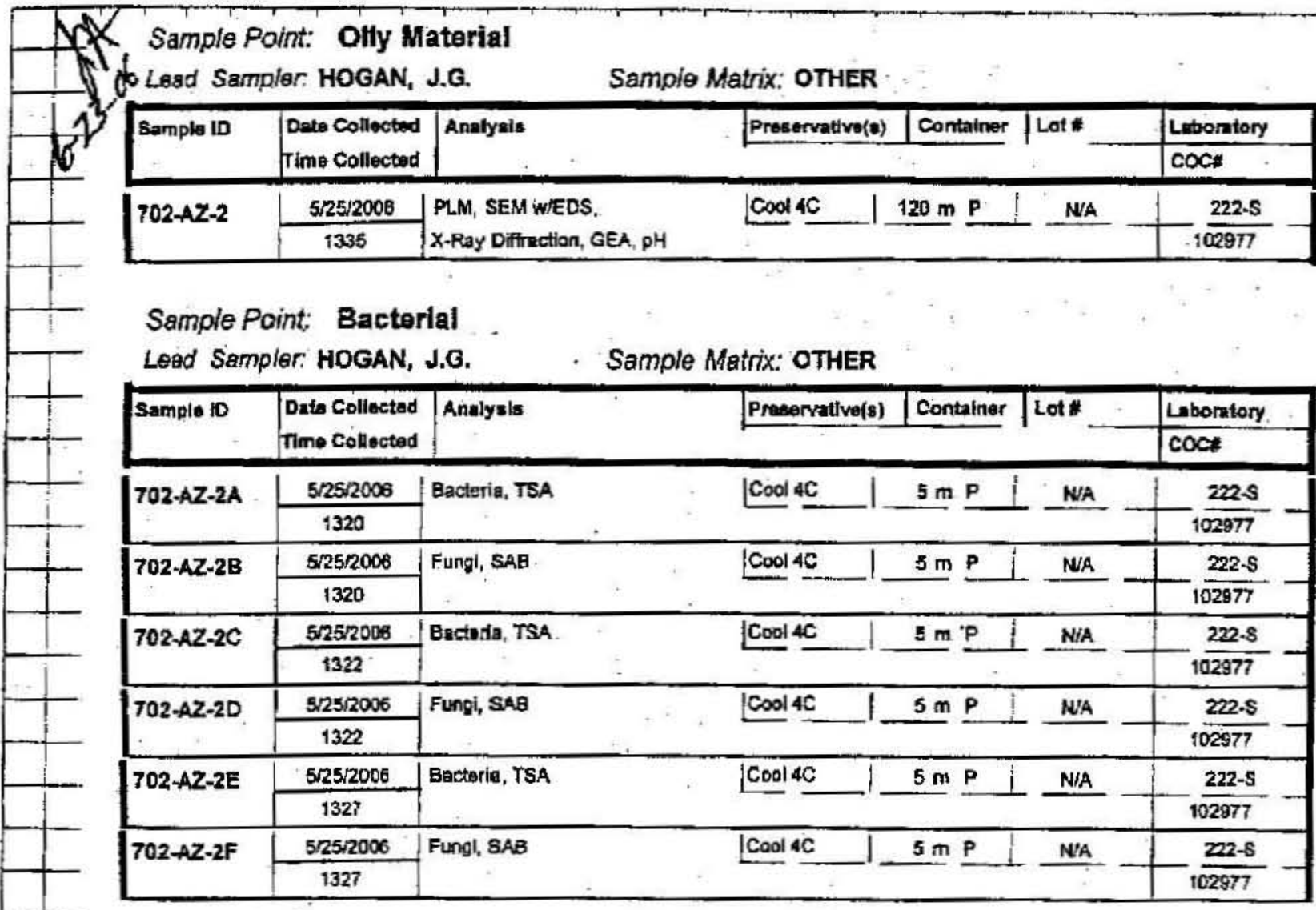

Sample Point: Field Blank

Lead Sampler: HOGAN, J.G.

Sample Matrix: OTHER

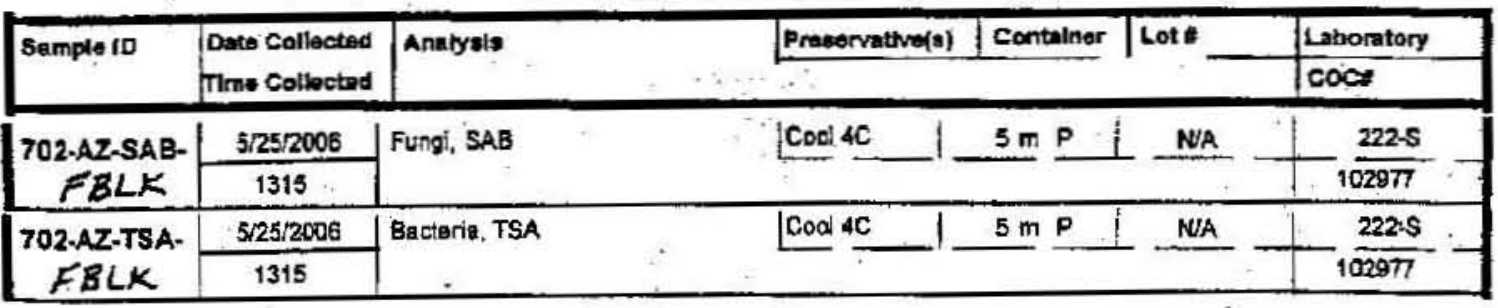

Sample Polnt: Trip Blank

Lead Sampler. HOGAN, J.G.

Sample Matrix: OTHER

\begin{tabular}{|c|c|c|c|c|c|c|}
\hline \multirow{2}{*}{ Sample ID } & \multirow{2}{*}{$\begin{array}{l}\text { Date Collected } \\
\text { Time Collected }\end{array}$} & \multirow[t]{2}{*}{ Anulysis } & Preservattve(d) & Container & \multirow[t]{2}{*}{ Lot \#. } & Laboratory \\
\hline & & & & & & $\mathrm{cocm}$ \\
\hline \multirow{2}{*}{$\begin{array}{l}\text { PO2.AZSAB- } \\
\text { TRPBLK }\end{array}$} & $5 / 25 / 2006$ & \multirow[t]{2}{*}{ Fungl, SAB } & \multirow{2}{*}{ Cool 4C. } & \multirow{2}{*}{$5 \mathrm{~m} P$} & \multirow[t]{2}{*}{ NA } & $222-5$ \\
\hline & 0800 & & & & & 102977 \\
\hline \multirow{2}{*}{$\begin{array}{l}\text { 702.AZ-TSA. } \\
\text { TRPBLK }\end{array}$} & $5 / 25 / 2005$ & \multirow[t]{2}{*}{ Bacterla, TSA } & \multirow[t]{2}{*}{$\mathrm{CoO}$ 4C } & \multirow[t]{2}{*}{$P \quad 1$} & \multirow[t]{2}{*}{ N/A } & $222-5$ \\
\hline & 0800 & & & & & 102977 \\
\hline
\end{tabular}

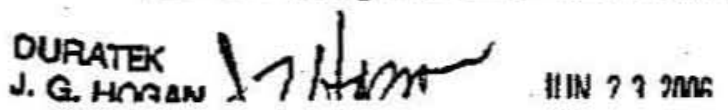

Read and Understood By 


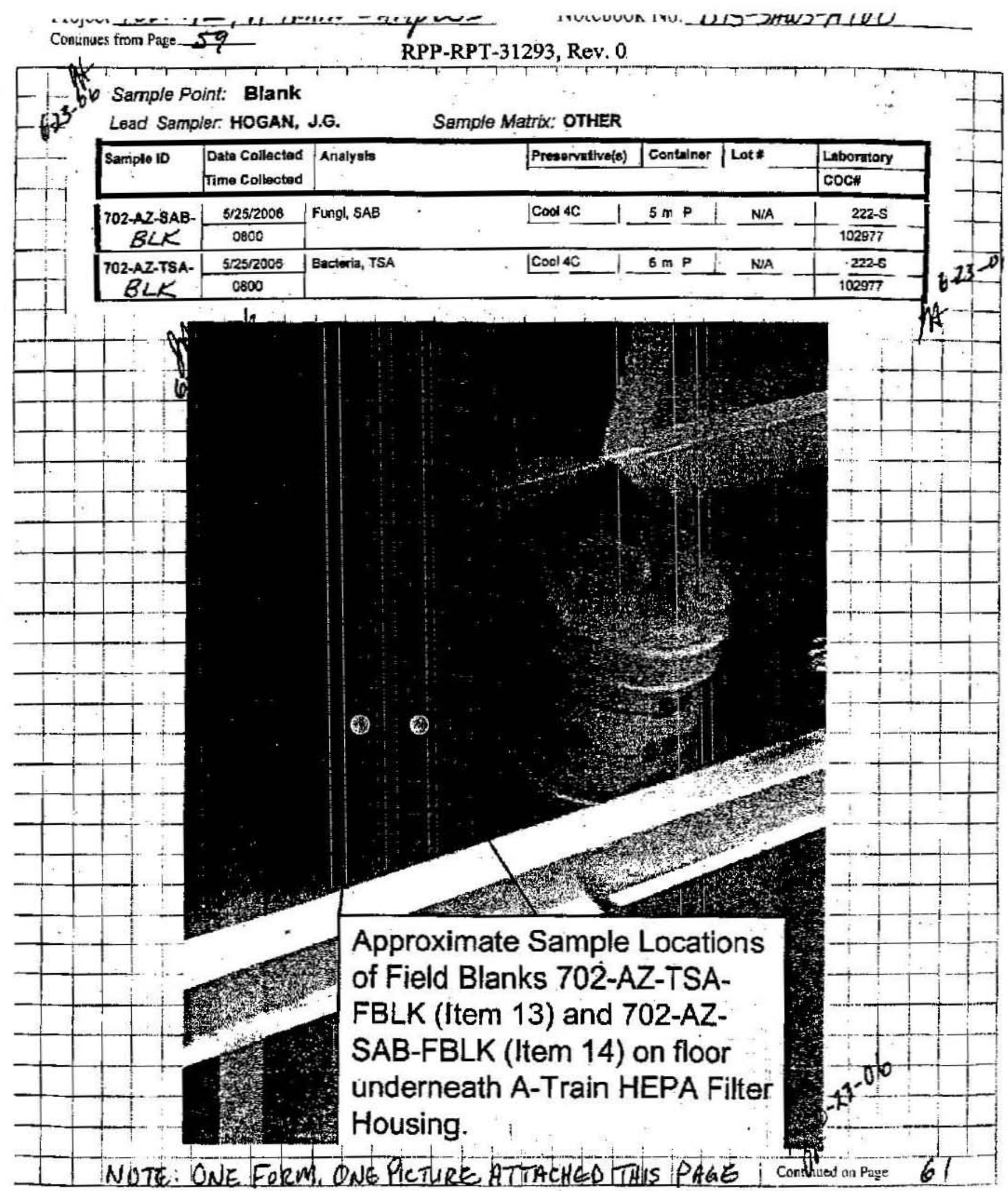

Reall ast Understood By 
RPP-RPT-31293, Rev. 0

Project $702 A Z, A$ TRA In SAmpLES
Continues from Page 60

Notebook No. DTS-SAWS-H/OC)

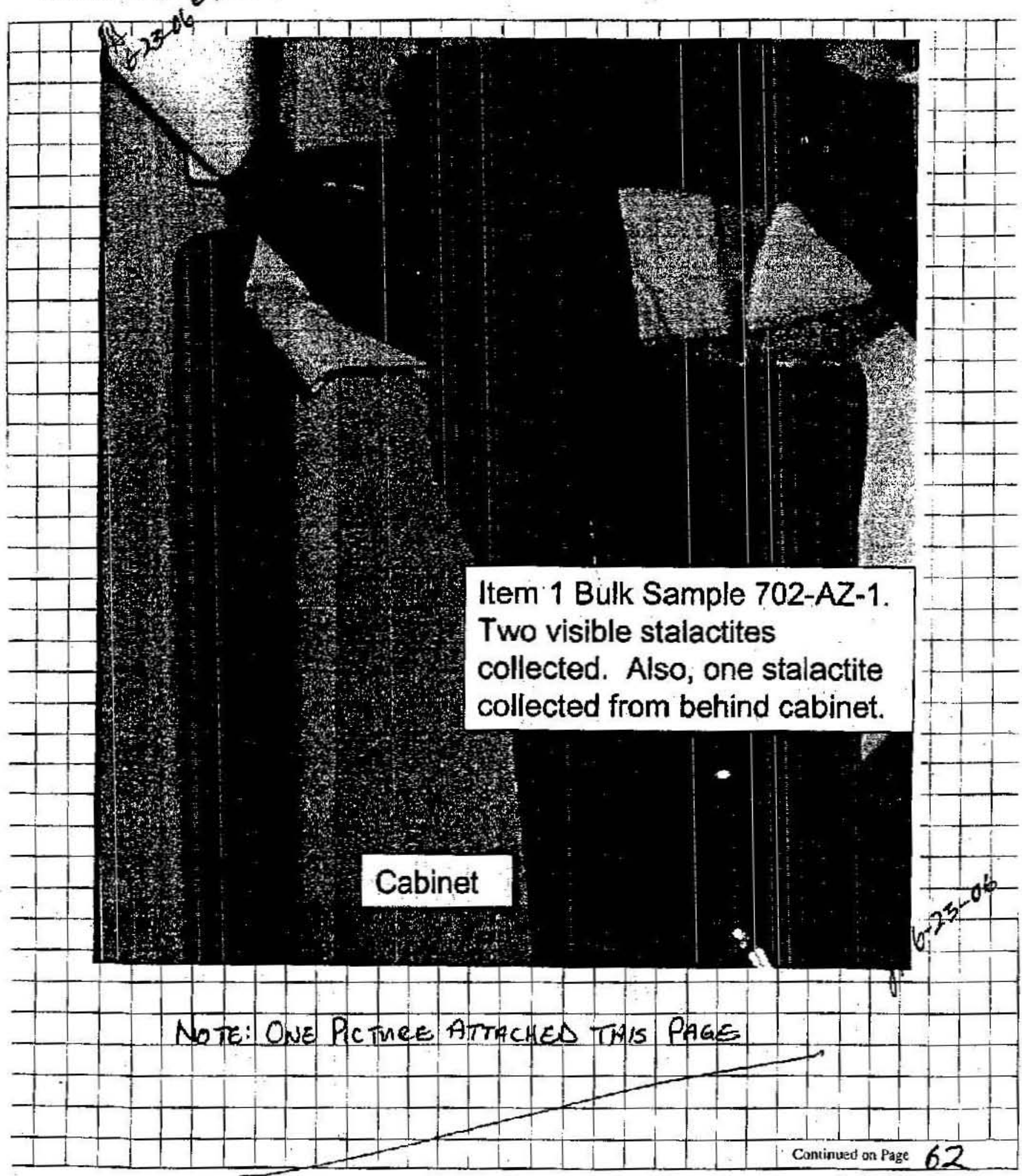

Read and Understood By 


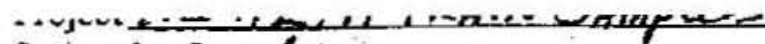

RPP-RPT-31293, Rev. 0

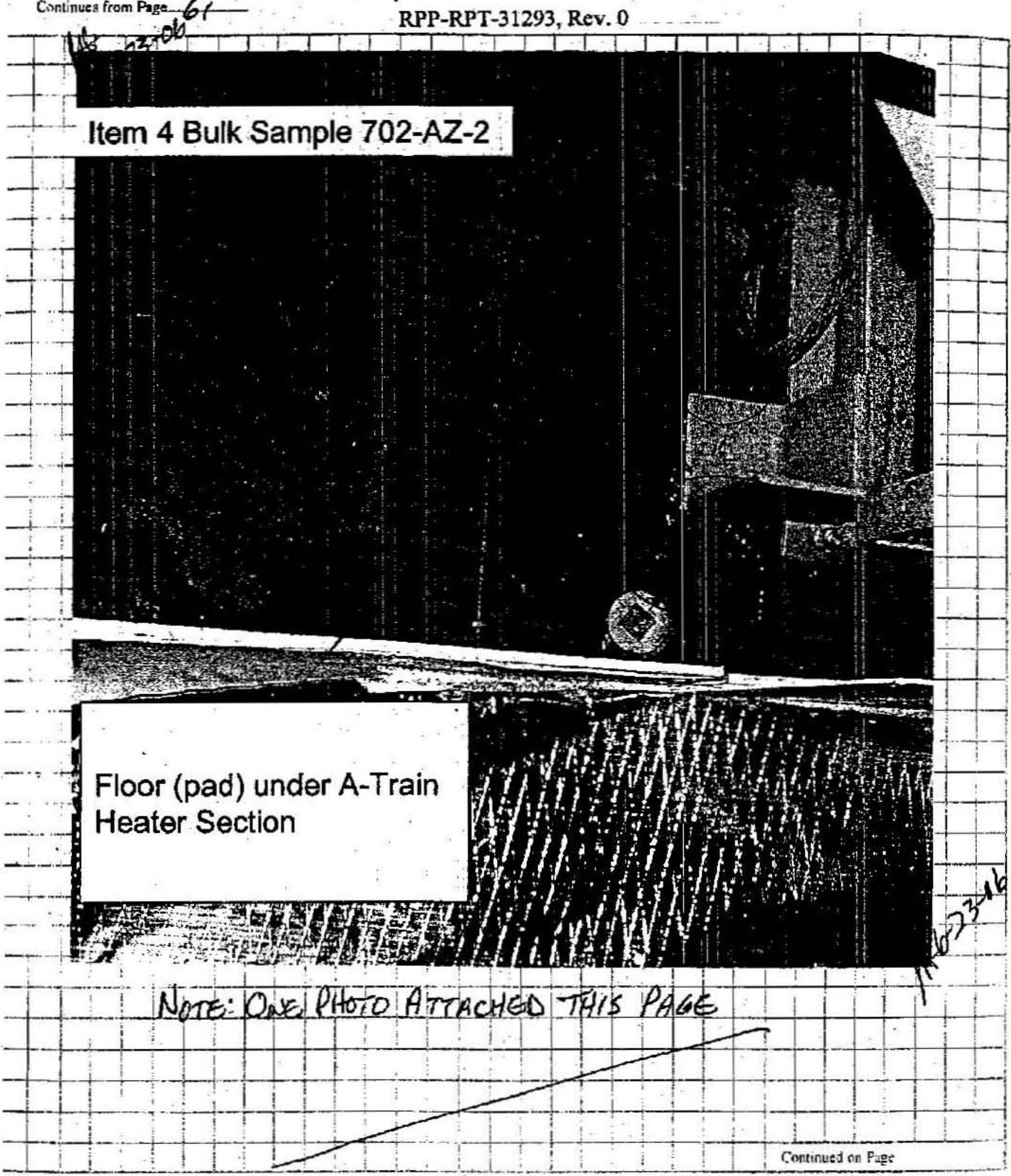

Read and Underatix 6 x 


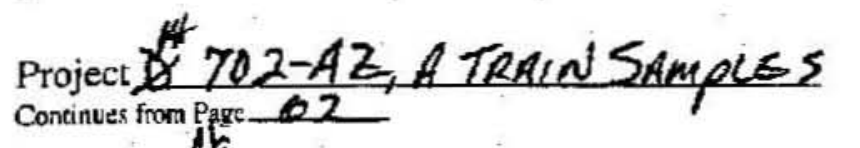

Notebook No. DTS-SAWS-H100

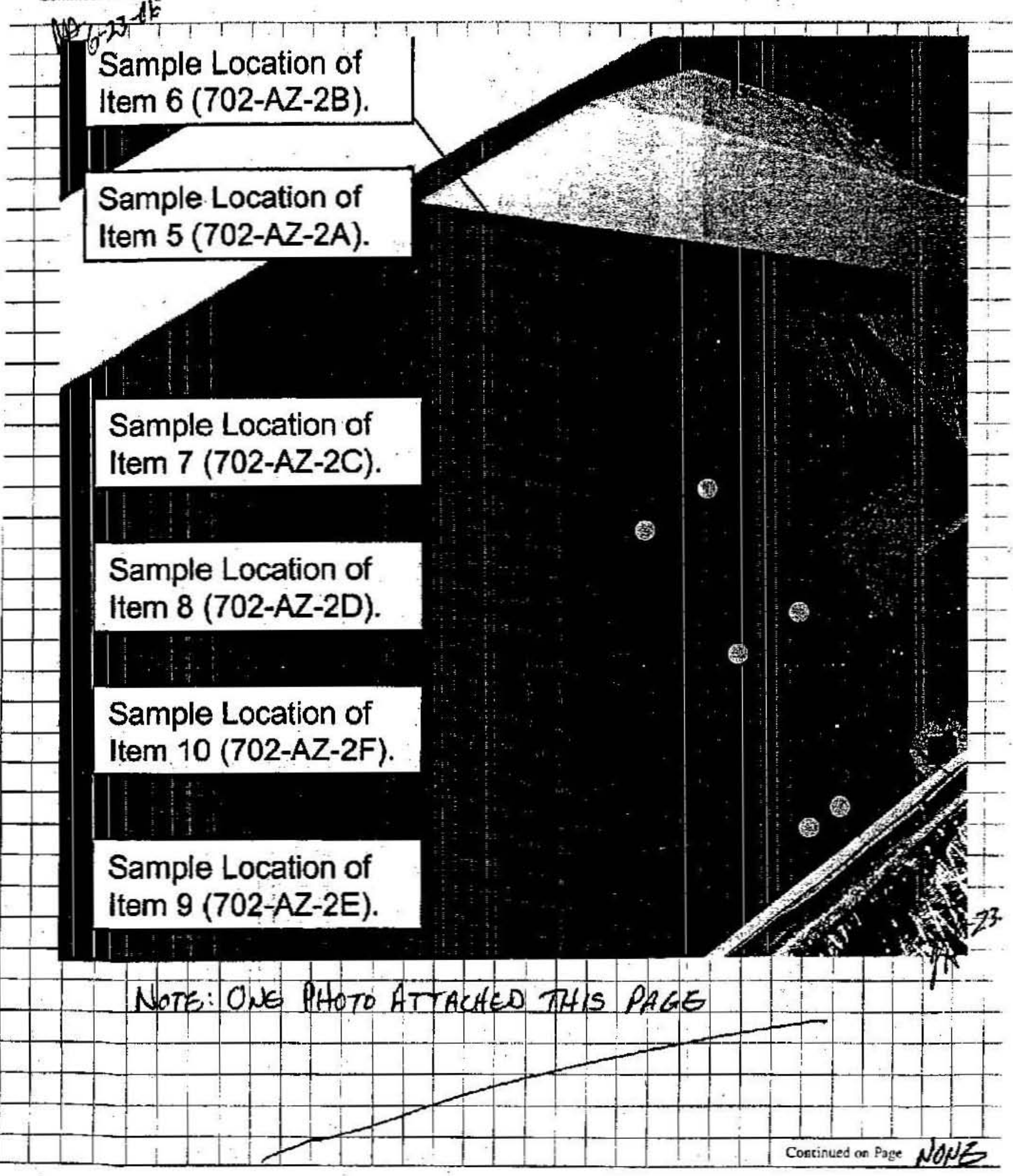

Read and Undersiood By 


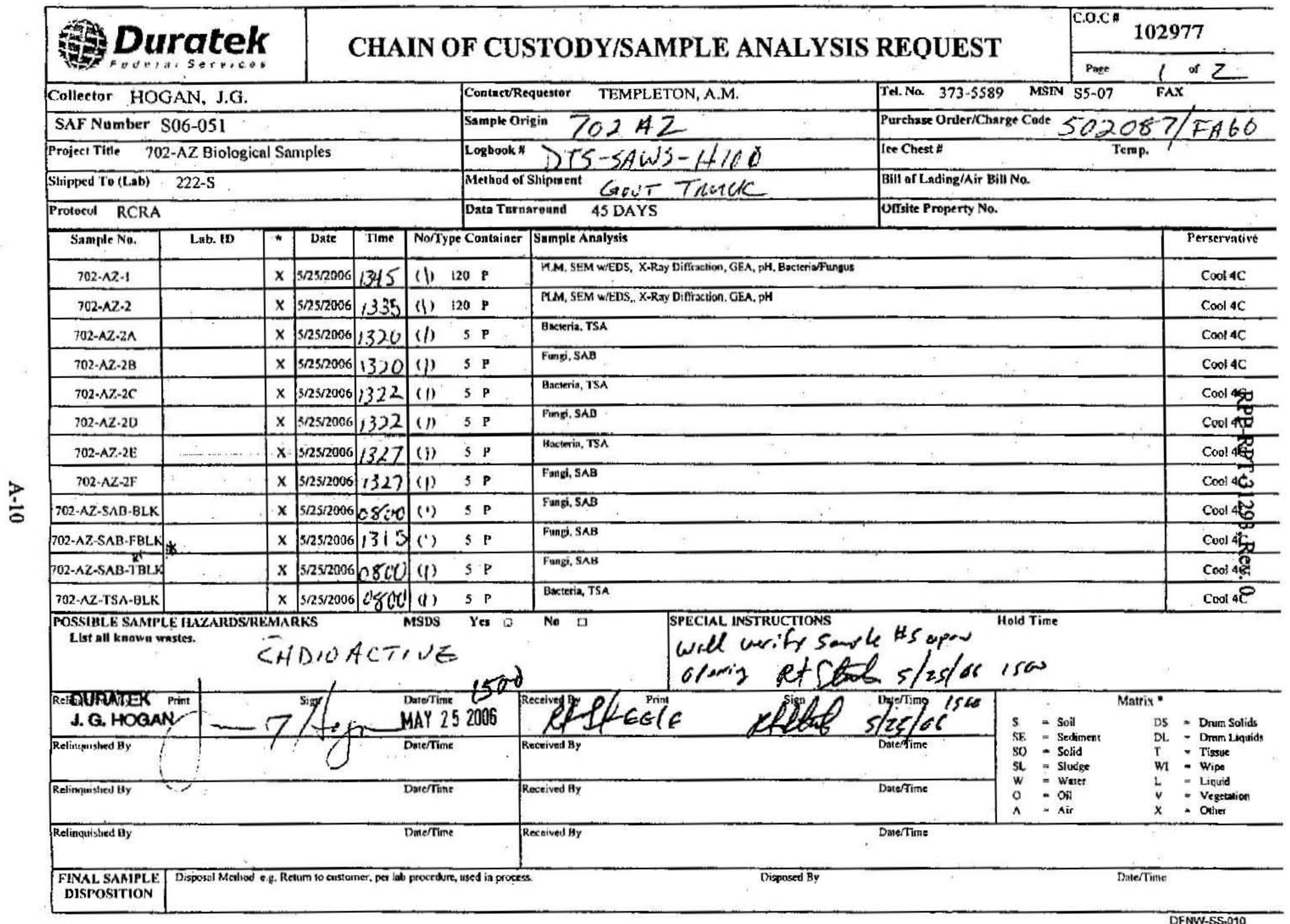




\begin{tabular}{|c|c|c|c|c|c|c|c|c|}
\hline \multirow{2}{*}{\multicolumn{3}{|c|}{ 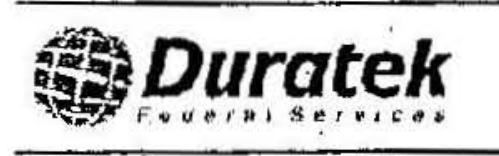 }} & \multirow{2}{*}{\multicolumn{5}{|c|}{ CHAIN OF CUSTODY/SAMPLE ANALYSIS REOUEST }} & \multirow{3}{*}{ 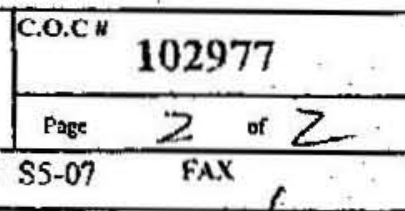 } \\
\hline & & & & & & & & \\
\hline \multicolumn{4}{|c|}{ Collector HOGAN, J.G. } & $\therefore$ & \multicolumn{2}{|c|}{ Contact/Requestor TEMPLETON, A.M. } & Tel. No. 373-5589 MSIN & \\
\hline \multicolumn{4}{|c|}{ SAF Number S06-051 } & & \multicolumn{3}{|c|}{ Sample Origin $\quad 30242$} & $502087 / 6 A 60$ \\
\hline \multicolumn{4}{|c|}{ Project Title $\quad 702-A Z$ Biological Samples } & & \multicolumn{2}{|c|}{ Logbook A DIS-SACJ S-HICV } & Iice Chest \# & Temp. \\
\hline \multicolumn{4}{|c|}{ Shipped To (Lab) $\quad 222-\mathrm{S}$} & & \multicolumn{2}{|c|}{ Nethod of Stipment GovT. Truck } & \multicolumn{2}{|l|}{ Bill or Lad ling/Air Bill No. } \\
\hline \multicolumn{2}{|l|}{ Protocol RCRA } & & & \multicolumn{2}{|c|}{ Drta Turnaround 45 DAYS } & \multirow[t]{2}{*}{ Ontaite Property No. } & \\
\hline Semple Nin. & Lub. ID & + & Datr & Titre & No/Type Contaluer & Sample Analysis & & Persernative \\
\hline 702-AZ-TSA-FALK & & $x$ & $5 / 25 / 2 \mathrm{D} 26$ & 13,5 & $5 \mathrm{P}$ & Bscteria, TSA & & Cool $4 \mathrm{C}$ \\
\hline TOZ-AZ-TSA-TBLLA & $\therefore$ & $x$ & $5 / 25 / 2006$ & osiv & (1) & Bacteria, TSA & & Cool 4C \\
\hline
\end{tabular}

$\stackrel{?}{!}$

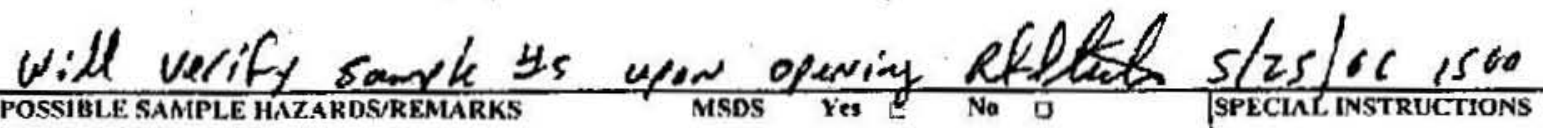

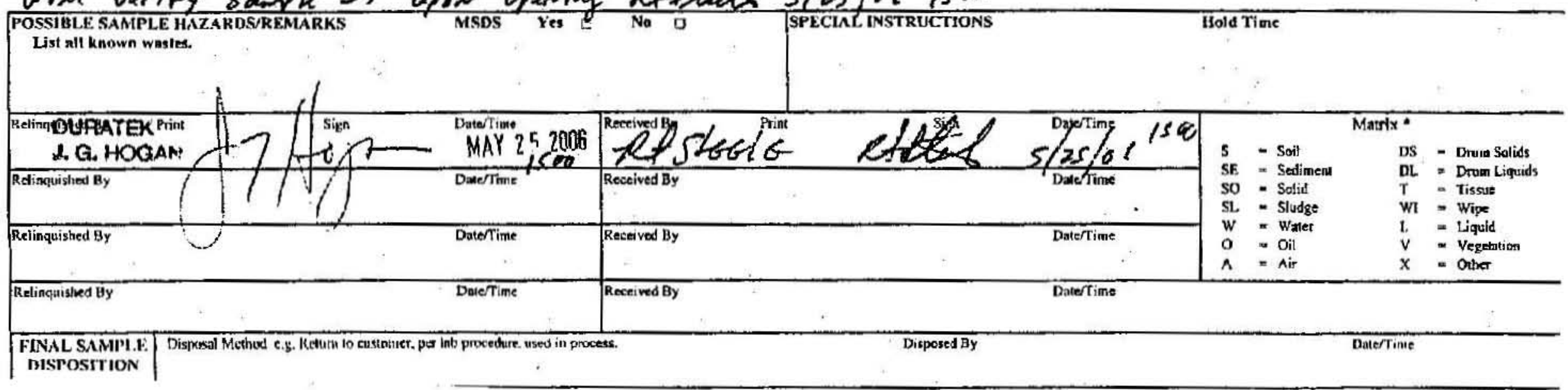


RPP-RPT-31293, Rev. 0

\section{Hogan, James G}

$\begin{array}{ll}\text { From: } & \text { Templeton, Andrew M } \\ \text { Sent: } & \text { Tuesday, March 28, 2006 4:19 PM } \\ \text { To: } & \text { Gardner, Martin G (Marty); Hogan, James G } \\ \text { Cc: } & \text { Frye, Jann M; Duncan, James B; Gustavson, Robert D; Jorgensen, David M } \\ \text { Subject: } & \text { FW: SAP }\end{array}$

Attachments: 702AZ SAP 3_20_06.doC

Marty and Jim,

Marty, I understand that Dave Jorgensen had talked to you some time ago about this sampling. We are assuming that you will be doing the sampling. Please find attached a draft sampling and analysis plan for your review. Section 4.0 deals with the sampling and will probably the section that is applicable to you guys.

If you have any questions please don't hesitate to call me at 373-5589 or on my cell \# $438=0701$.

Thanks!
Andrew M. Templeton
Component/System Engineer
DST Projects \& Maintenance Engineering
$\mathrm{CH} 2 \mathrm{M}$ Hill Hanford Group, Inc.

Ph. 509-373-5589

Fax 509-372-3106

Cell 438-0701

Andrew_M_Templeton@ri.gov

At CH2MHILL, squety is no accident

From: Duncan, James B

Sent: Monday, March 20, 2006 3:06 PM

To: Templeton, Andrew M

Cc: Frye, Jann M

Subject: SAP

Andrew,

I have incorporated your comments and merged with Bob Gustavson's comments. There are still some places to be filled in, like describe the HEPA and HEGA filters. If you want me to do that I can, but I thought TF might want to input specific to the filter manufacture rather than have a "how it works" paragraph.

After you get the SAP and have a chance to review and have it reviewed, please send back and we will get the tech editing done.

Thanks.

$\operatorname{Jim}$ 


\section{RPP-RPT-31293, Rev, 0}

\section{Hogan, James G}

From:

Sent:

To:

Ce:

Subject:
Marty Gardner [MGGARDNERQduratekinc.com]

Tuesday, April 11, 2006 6:40 AM

Meidrom, Clarence A Jr

Lippert, Tracy D; Reining, Timothy $L_{;}$Hogan, James $G$

702AZ Sampling

Al,

REgarding the upcoming sampling at 702-Az, we have been told that we are not to charge this work to the CHG sampling task under Wellingham. Duratek does not have a contract or task in place to support this sampling. Will need to get one placed and a CACN provided for the FH samplers to charge their time to. Let me know how you want to proceed.

Marty Gardner 
RPP-RPT-31293, Rev. 0

Hogan, James G

From: Duncan, James B

Sent: Wednesday, April 26, 2006 9:14 AM

To: Hogan, James G; Li, Shu-Mei W

Cc: Frye, Jann M; Duncan, James $B$

Subject: RODAC Surface sampling

Jim / Shu-Mei

Jann and I were discussing the RODAC sampling and decided to leave the SAP as is. The reason is we don't know the extent of the area to be sampied so it probably would be best to leave the plan as is. Besides not extending the RODAC sampling will minimize Jim's time on the walkway.

Thanks.

$\mathrm{Jim}$ 


\section{RPP-RPT-31293, Rev. 0}

\section{Hogan, James G}

From: Duncan, James B

Sent: Monday, April 24, 2006 12:28 PM

To: Hogan, James G

Subject: FW: PNNL Work

From: L, Shu-Mei W [mallto:shumei.li@pnl.gov]

Sent: Monday, April 24, 2006 12:03 PM

To: Duncan, James B; Frye, Jann $M$

Cc: LI, Shu-Mei W; Knight, Imalyn A; Quackenbush, Tonya P

Subject: RE: PNNL Work

Jim:

I have asked Toni to reserve room 69/331 building for 4/25/06, 3:00-4:00 PM. It is located in the 3rd floor.

Please forward this mail to whoever you want to invite to the meeting. Thanks.

Shu-mei

From: Li, Shu-Mei W

Sent: Monday, April 24, 2006 8:12 AM

To: Knight, Imalyn A

Subject: RE: PNNL Work

Imalyn:

Please schedule a meeting room in 331 bldg. for Tuesday, April 25, 2006 3:00 PM-4:00 PM. Thanks.

Shu-mei

From: LI, 5hu-Mei W

Sent: Saturday, April 22, 2006 2:31 PM

To: Knight, Imalyn A

Subject: FW: PNNL Work

Imalyn:

Do we have a meeting room available at that time? Thanks.

Shu-mei

From: $U$, Shu-Mei W

Sent: Thursday, April 20, 2006 4:50 PM

To: Duncan, James B 


\section{RPP-RPT-31293, Rev. 0}

Ce: Knight, Imalyn A

Subject: RE: PNNL Work

Tuesday, Aprll 25, 2006 3:00 PM-4:00 PM.

Jim:

I have received your phone message. 6/25/06 Tuesday at $3 \mathrm{PM}$ is fine with me. I will ask our administrator Imalyn to reserve a room at 331 building. Thanks.

Shu-mei

Imalyn: Please set up a meeting place for us. Thanks.

From: Duncan, James B

Sent: Thursday, April 20, 2006 2:45 PM

To: Templeton, Andrew M

CC: Li, Shu-Mei W; Brockman, Fred J

subject: PNNL Work

Andrew,

I spoke with Shu-Mei and she has not yet have a work package. I need to set up a meeting with her, Jim Hogan, Jann and myself to converge on all sampling items and get them on order.

Could you check on the status and email Shu-Mei and Fred to give PNNL a POC for checking into the status of the work package.

Thanks.

$\mathrm{Jim}$ 


\section{Sampling and Analysis Plan for Building 241 702-AZ A Train}

3. B. Duncan and J. H. Frye CH2M HILT Hanford group. Inc.

Richland, WA 99352

U.S. Depariment of Energy Contract DE-AC27-99RL14047

$\begin{array}{ll}\text { EDT/ECN: DRF } & \text { UC: } \\ \text { Cost Center: 7S110 } & \text { Chatge Code: } \\ \text { B\&R Code: } & \text { Total Pages: 21 }\end{array}$

Key Words: sampling, analysis, plan, 702-A2, A trais, PBR, ventilation, fliter roor, alcroblological, radiological, PCB, erystalline, nethods, requirements, trypticase soy agar, Sabouraud dextrose agar, blologlcal

Abstract: The 702 Az A traln has been observed co have crystalilne matexial of unknown origin emanating fron an area below the exhaust heater and filtar housing as well as brownish-black materlal on the floor in close proximlty to the filter housing. also of unknown origin. The purpose of this plan is to outline the key elements for sampling and analyzing both the erystalline material and tha material on the floor.

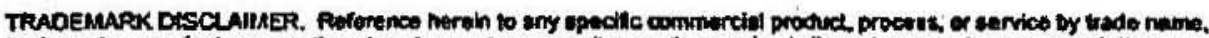

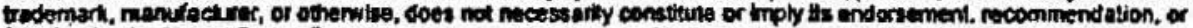
favoring by the Uniled siaves Coveramint or any sgency thervof or ths contractors of subcentradars.

Printed in me Uniled States of Amarics. To oblach coples of his doament, conlact Document Control Services. P.O. Box 950. Mallslop He-cs, Richiand WA 09352. Phone (509) 372-2420;, Fax (509) 378-4969.

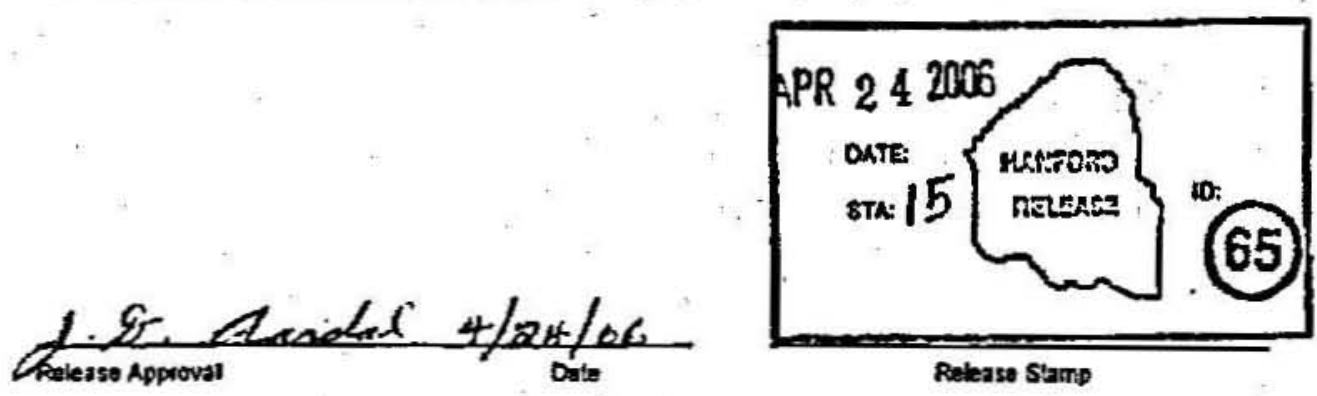

Approved For Public Release 


\section{2-AZ A-Train Leakage Sample Evolution (WFO-WO-05-000646) $5 / 25 / 2006$ Sample Locations}

Refer to RPP-PLAN-28509, Table 7 for Sample Collection Identification Numbers 
RPP-RPT-31293, Rew. 0 -

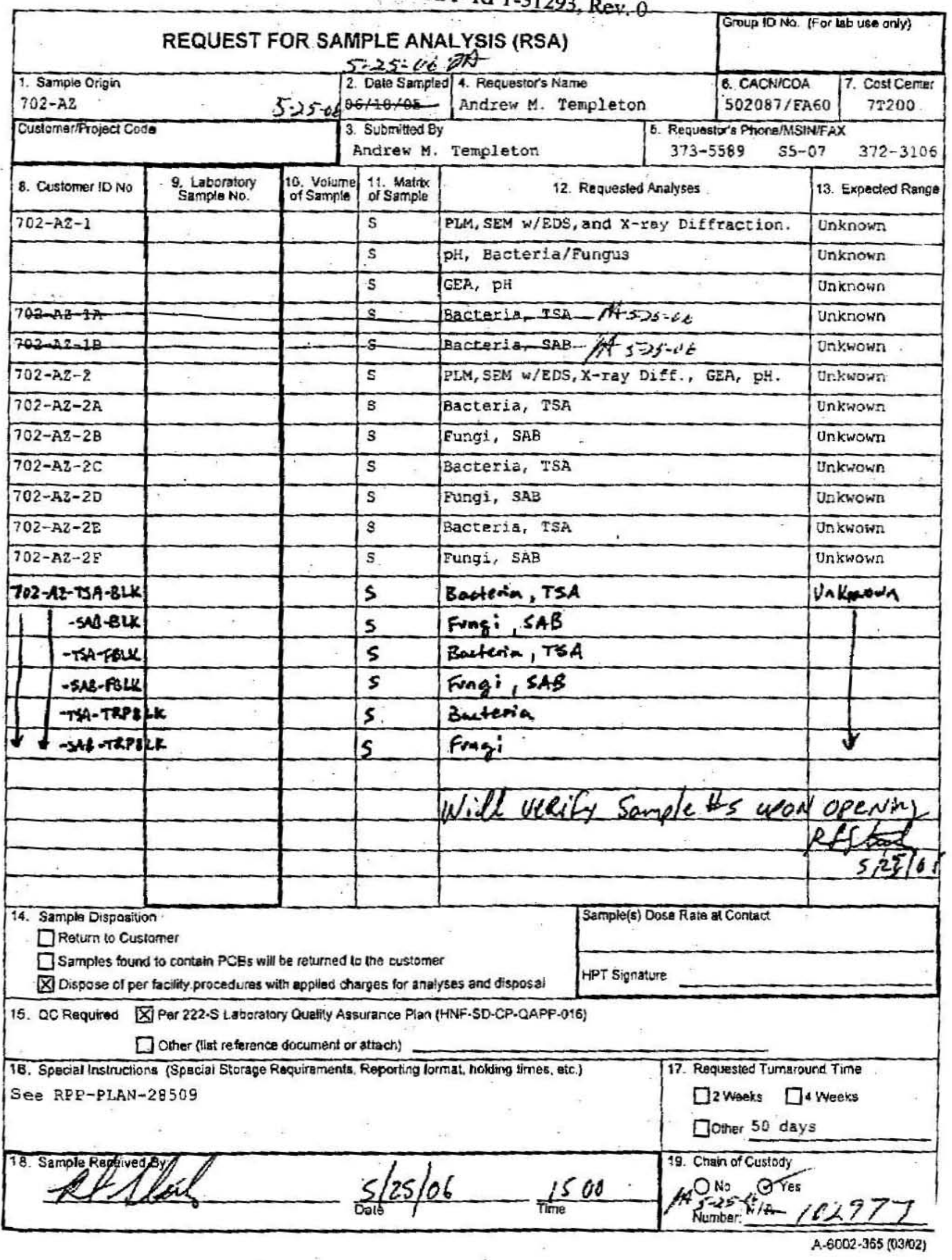


RPP-RPT-31293, Rev: 0

TWP
$W T O-O 22-R E V I$ WOK ORDER-

CKEARnay NCO

RDGustauson ENG

WL ADAmS IH

IS TOLE IA

I TRON

D AnDERSON

R channel

D Jarazuson Planner

SRCHAPMAN PIC $3.3770308-7806$

A-20 


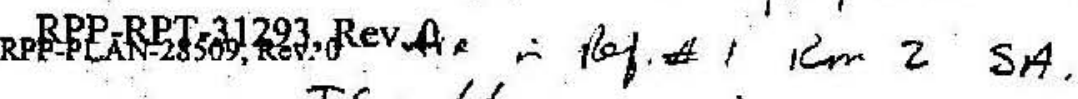

$$
\begin{aligned}
& \text { Jim - Pu Afor plotes } \\
& 845-36>2(c) \quad 3>3-1972
\end{aligned}
$$

Table 7. Sample Collection.

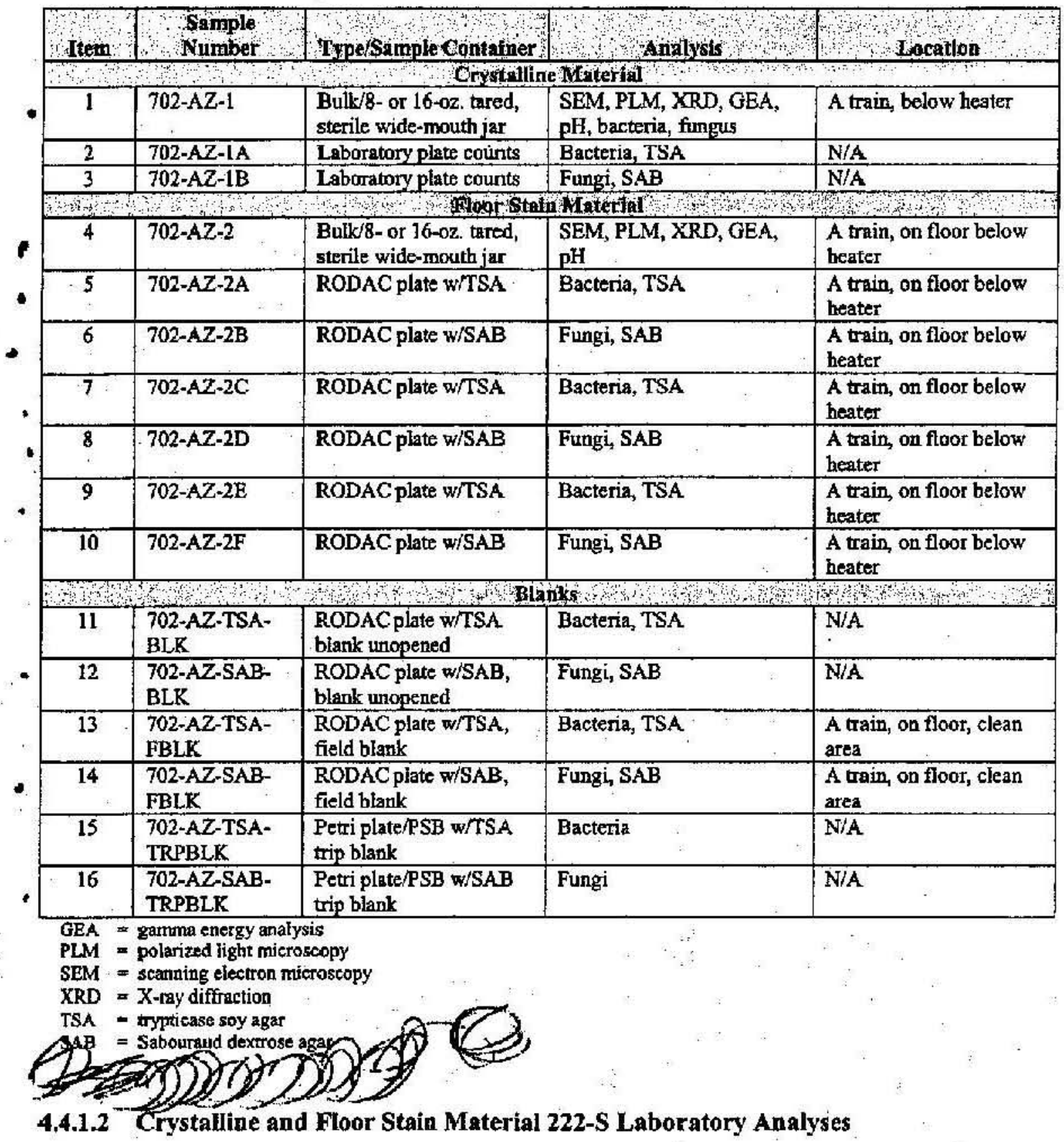

A known mass of the samples (crystalline and floor stain) collected will be subjected to $\mathrm{pH}$, using the procedure LA-212-105, "pH Determination of Solid Wastes," method. The material will also be analyzed for PCBs using LA-523-141, "Screening Procedure for Polychlorinated Biphenyls." A gamma energy analyses will be performed using the procedure LA-508-165, "Gamma Energy Analysis - The Genie 2K System." For quality control parameters see Table 8. 


\section{CH2M HILL DOCUMENT RELEASE FORM}

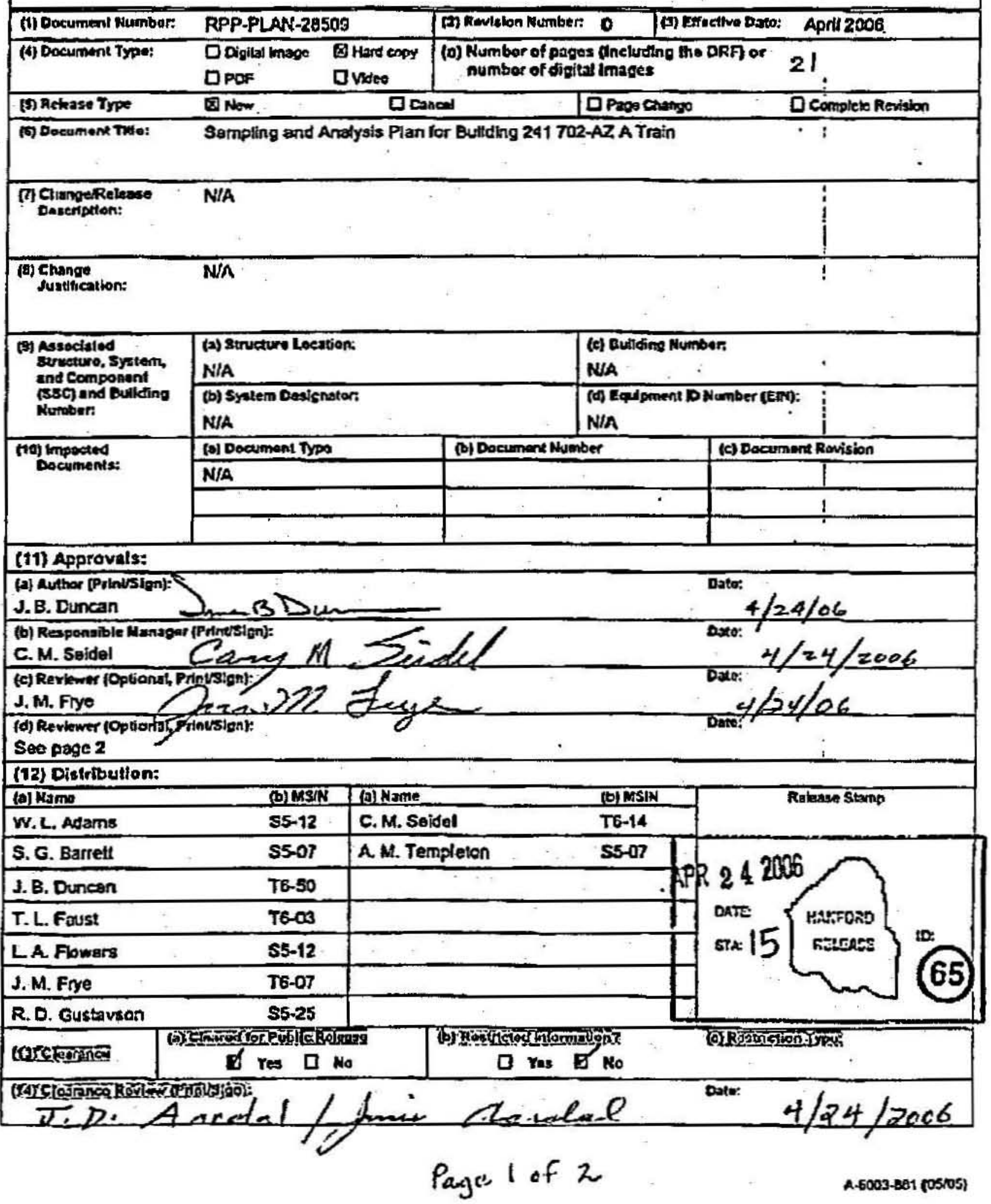


$0 \$ 121108$ 11:38 FhJ 5095738180

RPP-RPT-31293, Rev. 0

\section{CH2M HILL DOCUMENT RELEASE FORM (Continued)}

\begin{tabular}{|l|l|l|}
\hline (1) Documant Number: RPPPLAN-28509 & (2) Rovision Number: 0 & (3) Efloctivo Date: 4/2006 \\
\hline
\end{tabular}

(11) Approvals: (Continued)

(E) Environmental Complizpga (Prinursigen)

T.L. Faust SPTL

(d) Industrial Hygiene (pridtsign

W. L. Adems

(o) Projoct Mainter ance and Engityoding (Pintsigni:

A. M. Termpleton

(i) RADCON (Print'sign):

S. G. Earrets

s.ter

(a) Safety (Printrsign)

L. A. Flowers

(h) Syctom Engined (Print(Sign)

R. D. Gustavson

RP

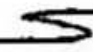

$>$

$\rightarrow$

$R+R$

Date $y / 24 / 06$

Date

4/20/06

Deto $4 / 20 / 06$

Date $4 / 20 / 06$

Data

Dolo $4 / 201 / 06$

$4 / 20 / a r$

! 


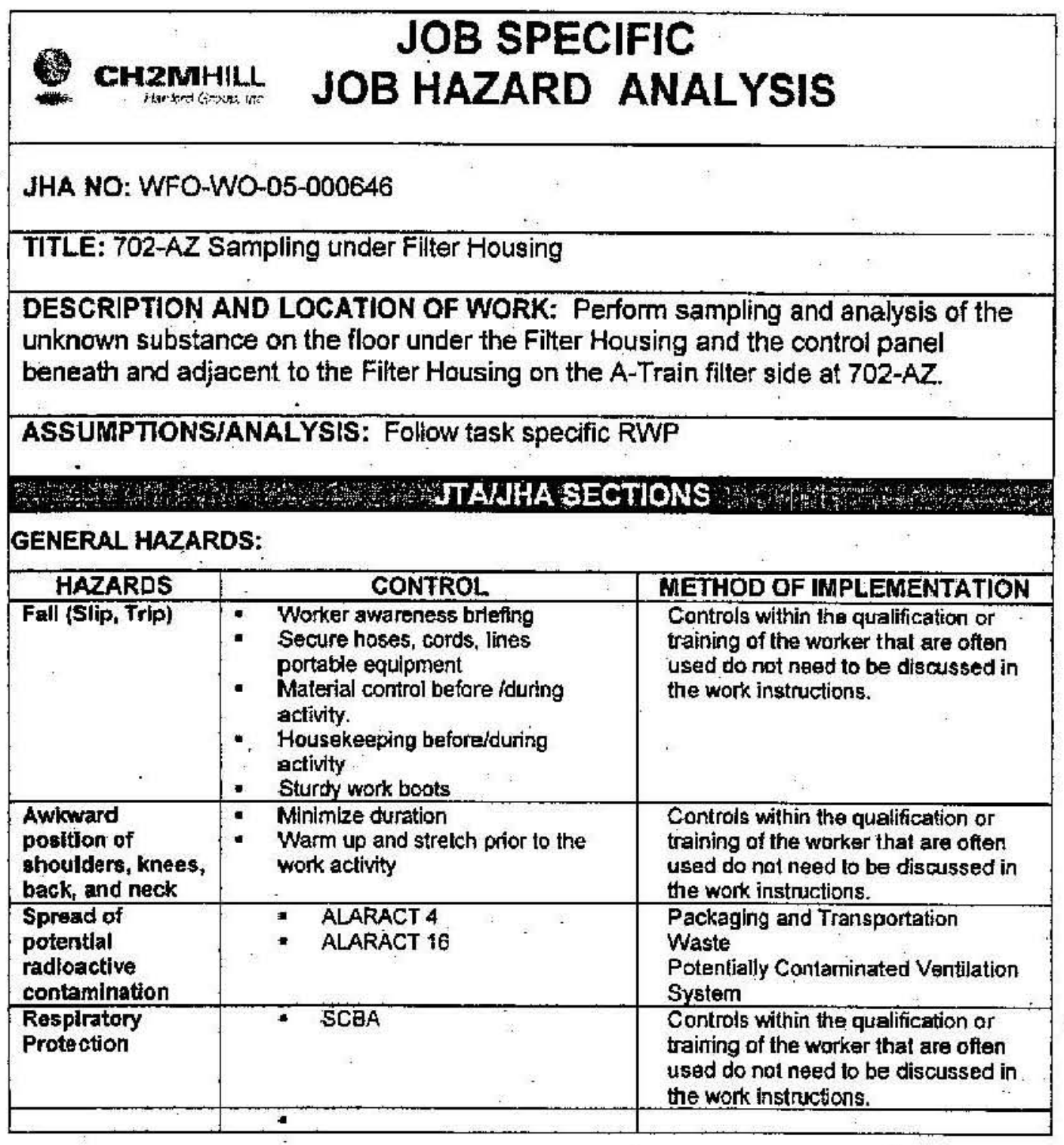

\begin{tabular}{|l|l|l|}
\hline \multicolumn{2}{|c|}{ COSK 1: Prepare area for sampling } \\
\hline \multicolumn{1}{|c|}{ HAZARDS } & $\begin{array}{l}\text { CPE } \\
\text { Ground Cover }\end{array}$ & $\begin{array}{l}\text { METHOD OF IMPLEMENTATION } \\
\text { training of the worker that ate often } \\
\text { used do not need lo be diseussed in } \\
\text { the work instructions. }\end{array}$ \\
\hline $\begin{array}{l}\text { radioactive } \\
\text { contamination }\end{array}$ & $\begin{array}{l}\text { Swilch fans to B-train or wear } \\
\text { hearing protection }\end{array}$ & $\begin{array}{l}\text { Controls within the qualification or } \\
\text { training of the worker but are seldorn } \\
\text { used and are applicable to the entire } \\
\text { work activity should be placed in the } \\
\text { precautions as a reminder that the } \\
\text { hazard exists and the workers are } \\
\text { expected to take the appropriate } \\
\text { actions. }\end{array}$ \\
\hline $\begin{array}{l}\text { Nolse (>85 dBA } \\
\text { Ghr. TWA) }\end{array}$
\end{tabular}




\begin{tabular}{|l|l|l|}
\hline \multicolumn{1}{|c|}{ TASK 2: Perform baseline survey } \\
\hline \multicolumn{1}{|c|}{ HAZARDS } & \multicolumn{1}{|c|}{ CONTROL } & METHOD OF IMPLEMENTATION \\
\hline $\begin{array}{l}\text { Spread of } \\
\text { contamination }\end{array}$ & $\begin{array}{l}\text { PPE } \\
\text { Clean area Survey only } \\
\text { Building Ventilation on } \\
\text { Door closed }\end{array}$ & $\begin{array}{l}\text { Controis within the quatification or } \\
\text { training of the worker that are often } \\
\text { used do not need to be discussed in } \\
\text { the work instructions. }\end{array}$ \\
\hline $\begin{array}{l}\text { Alr Borne } \\
\text { Radloactlvity }\end{array}$ & Air Sampler & $\begin{array}{l}\text { Controls within the qualification or } \\
\text { training of the worker that are often } \\
\text { used do not need to be discussed in } \\
\text { the work instructions. }\end{array}$ \\
\hline
\end{tabular}

\section{TASK 3: Monitor for orgenics}

\begin{tabular}{|l|l|l|}
\hline \multicolumn{1}{|c|}{ HAZARDS } & \multicolumn{1}{|c|}{ CONTROL } & METHOD OF IMPLEMENTATION \\
\hline $\begin{array}{l}\text { Chemicals } \\
\text { NOC }\end{array}$ & $\begin{array}{l}\text { IH monitoring-area (Before and } \\
\text { after) }\end{array}$ & $\begin{array}{l}\text { Controls within the qualification or } \\
\text { training of the worker that are oflen } \\
\text { used do not nesed to be discussed in } \\
\text { the work instructions. }\end{array}$ \\
\hline
\end{tabular}

\begin{tabular}{|c|c|c|}
\hline HAZARDS & CONTROL & METHOD OF IMPLEMENTATION \\
\hline & 7 & \\
\hline Alrborne & $\begin{array}{l}\text { - } \quad \text { Building contamination } \\
\text { Ensure building ventilation } \\
\text { system is on }\end{array}$ & $\begin{array}{l}\text { Controls within the qualification or } \\
\text { training of the worker that are often } \\
\text { used do not need to be discussed in } \\
\text { the work instructions. }\end{array}$ \\
\hline $\begin{array}{l}\text { Spread of } \\
\text { contarnination }\end{array}$ & $\begin{array}{l}\text { - Ground cover } \\
\text { PPE - Tyvek suit, two pairs of } \\
\text { gloves } \\
\text { - Wrap container outer } \\
\text { Collection tools }\end{array}$ & $\begin{array}{l}\text { Controls within the qualification or } \\
\text { training of the worker that are often } \\
\text { used do not need to be discussed in } \\
\text { the work instructions. }\end{array}$ \\
\hline $\begin{array}{l}\text { Contact wl } \\
\text { substance }\end{array}$ & $\begin{array}{l}\text { Two pair gloves, outer pair } \\
\text { Nitrile } \\
\text { - Tyvek suit for sample takers } \\
\text { - Knee pads if desired }\end{array}$ & $\begin{array}{l}\text { Controts within the qualification or } \\
\text { training of the worker but are seidom } \\
\text { used and are applicable to the entire } \\
\text { work activity should be placed in the } \\
\text { precautions as a reminder that the } \\
\text { hazard exists and the workers are. } \\
\text { expecled to take the appropriate } \\
\text { actions. }\end{array}$ \\
\hline & $*$ & \\
\hline
\end{tabular}




\begin{tabular}{|c|c|c|}
\hline HAZARDS & CONTROL & METHOD OF IMPLEMENTATION \\
\hline & $\bullet$ & \\
\hline Airborne & $\begin{array}{l}\text { Ensure building ventilation } \\
\text { system is on }\end{array}$ & $\begin{array}{l}\text { Controls within the qualification or } \\
\text { training of the worker that are often } \\
\text { ussd do not need to be discussed in } \\
\text { the work instructions. }\end{array}$ \\
\hline $\begin{array}{l}\text { Spread of } \\
\text { contamination }\end{array}$ & $\begin{array}{l}\text { - Ground cover } \\
\text { - } \text { gloves - Tyvek suit, two pairs of } \\
\text { - Wrap container outer } \\
\text { - Re-lape cut opening in plastic } \\
\end{array}$ & $\begin{array}{l}\text { Controls within the qualification or } \\
\text { training of the worker that are often } \\
\text { used do not need to be discussed in } \\
\text { the work instructions. }\end{array}$ \\
\hline & $\because$ & \\
\hline $\begin{array}{l}\text { Contact wl } \\
\text { substance }\end{array}$ & $\begin{array}{l}\text { Two pair gloves, outer pair } \\
\text { Nitrile } \\
\text { Tyvek suit for sample takers }\end{array}$ & $\begin{array}{l}\text { Controls within the qualification or } \\
\text { training of the worker but are seldom } \\
\text { used and are applicable to the entire } \\
\text { work activity should be placed in the } \\
\text { precautions as a reminder that the } \\
\text { hazard exists and the workers are } \\
\text { expected to take the appropriate } \\
\text { actions. }\end{array}$ \\
\hline Sharp Objects & $\begin{array}{l}\text { Sheathe when not in use } \\
\text { Cut materials such that cutting } \\
\text { motian is away from the body vs. } \\
\text { toward the body to prevent injury } \\
\text { in case of slipping. }\end{array}$ & $\begin{array}{l}\text { Cantrols within the qualification or } \\
\text { training of the worker that are often } \\
\text { used do not need to be discussed in } \\
\text { the work instructions. }\end{array}$ \\
\hline
\end{tabular}

\begin{tabular}{|l|l|l|}
\hline \multicolumn{2}{|l|}{ TASK 6: Prepare for transport (chain of custody) } \\
\hline \multicolumn{1}{|c|}{ HAZARDS } & \multicolumn{1}{|c|}{ CONTROL } & METHOD OF IMPLEMENTATION \\
\hline $\begin{array}{l}\text { Spread of } \\
\text { contamination }\end{array}$ & $\begin{array}{l}\text { Remove wrapping } \\
\text { DECON }\end{array}$ & $\begin{array}{l}\text { Controls within the qualtication or } \\
\text { training of the worker that are often } \\
\text { Sured do not need to be discussed in } \\
\text { the work instruclions: }\end{array}$ \\
\hline $\begin{array}{l}\text { Package for transport } \\
\text { Label package }\end{array}$ & \\
\hline
\end{tabular}


RPP-RPT-31293, Rev. 0

\begin{tabular}{|l|l|l|}
\hline \multicolumn{2}{|c|}{ TASK 7: Clean up area } & \multicolumn{1}{|c|}{ CONTROL } \\
\hline HAZARDS & $\begin{array}{l}\text { Area Sample } \\
\text { Post job Survey } \\
\text { Down post }\end{array}$ & $\begin{array}{l}\text { Controls within the qualification or } \\
\text { training of the worker that are often } \\
\text { used do not need to be discussed in } \\
\text { the work instructions. }\end{array}$ \\
\hline $\begin{array}{l}\text { Spread of } \\
\text { contamination }\end{array}$ & & \\
\hline
\end{tabular}


RPP-RPT-31293, Rev, 0

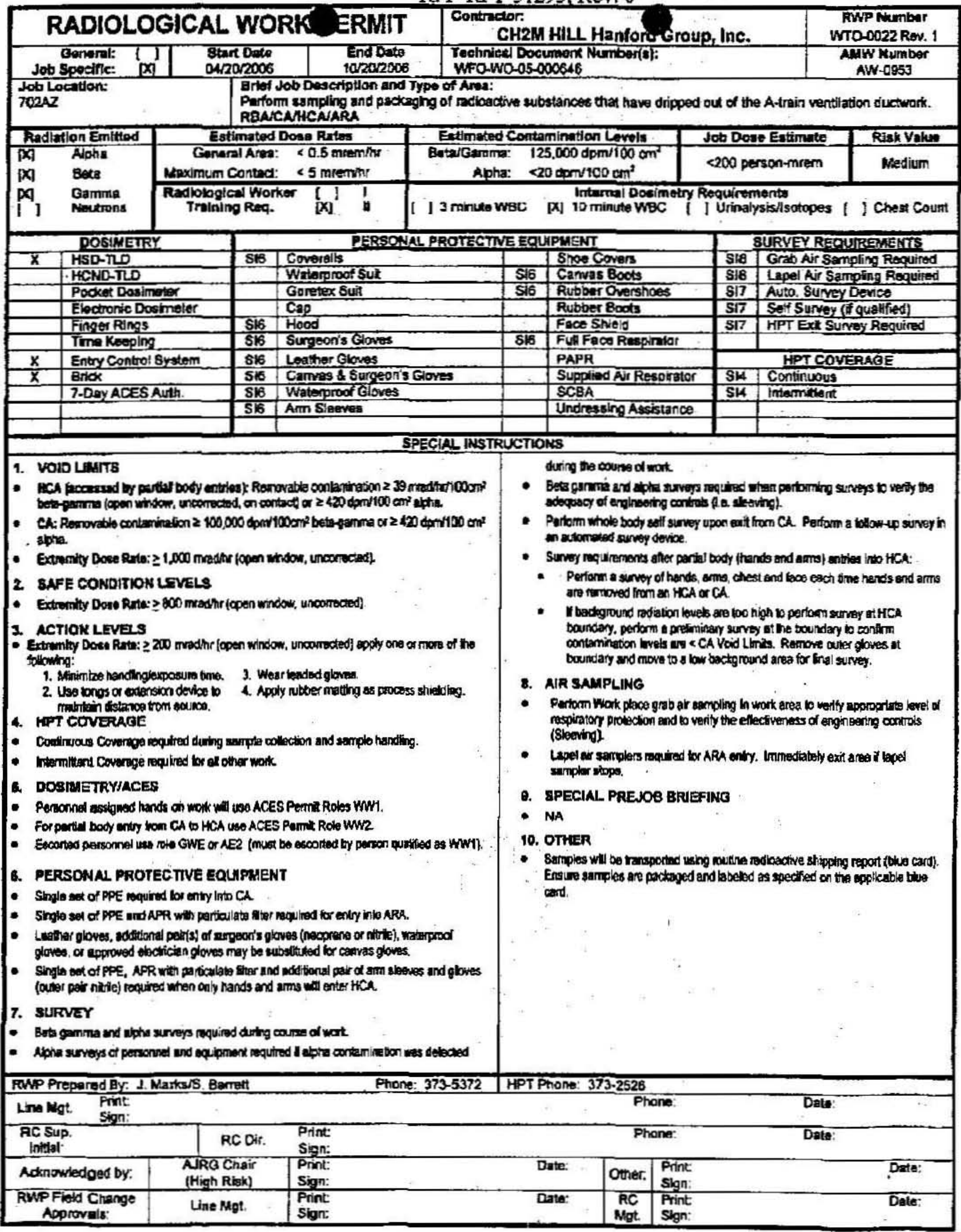


RPP_RPT_21203 Rev 0

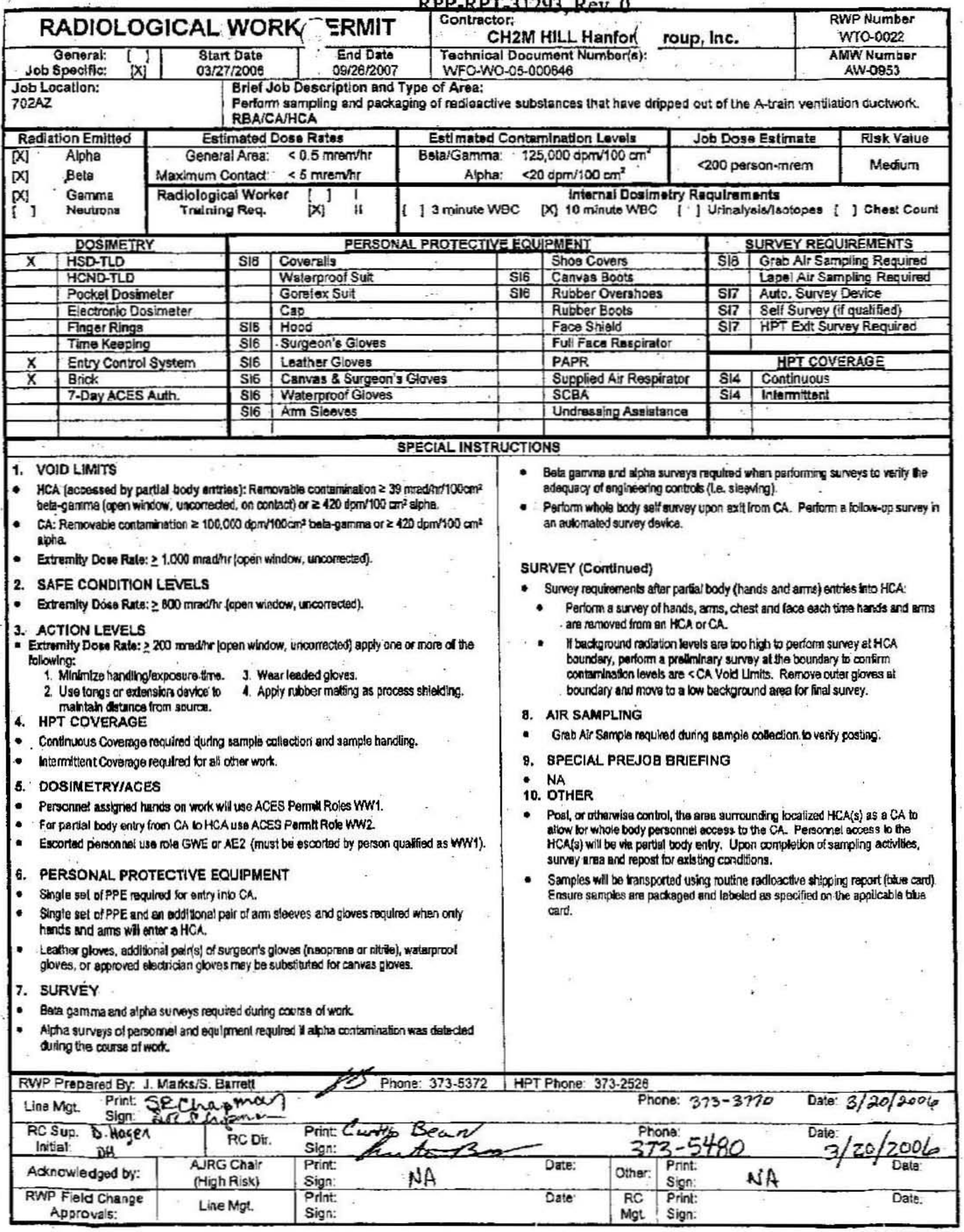

1. VOID LIMITS

HCA (acsessed by partial body entries): Femovable contaninalion 239 mradint $100 \mathrm{~cm}$

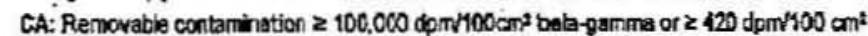
Extremilty Dove Rale: $\geq 1.000$ mradhr (open window, uncorrected).

2. SAFE CONDITION LEVELS

3. ACTION LEVELS

Extromity Doth Rata: 2200 modedhr lopen window, uncorrecteos apply one or more ar the

1. Minimize handinglexposure:tino. J. Wear leeded gloves.

Use torgs or extensiba davice to 1. Apply rubber mating as process stielding.

- Conthuous Coverkge required duding sample collection and sample handling.

5. DOSIMETRYJACES

Persconnel assigned handes on work wit

- Escortad personnel use role GWE or AE2 (must be escortad by person qualfied as WW1).

G. PERSONAL PROTECTIVE EOUIPMENT

Leather gloves, addlitional pari's) of sungeor's glowes insoprene or nittiel, watarproof

SURVÉY

Alpha surveys of persomel and equ/pmenl requlred II alpha contamination was detected

duing the course of wotk
Beta gamna and alpha surveys requitred whan parforming suneys to verity the

Portom

URVEY (Continued)

urvey requirements atg are removed from an $\mathrm{HCA}$ or $\mathrm{CA}$.

If becknound radiation levels are too hich to contaring a prom bounclany and move to a low beckground area for final suney.

gpecial prejog briefing atiow bo whole body personnel access to the CA. Persomel accets bo the HCA(s) will be vie pertiel body enly. Upon completion of sampling activites, Ensure semntes are packaged and labeled as specified on the appilcabla bifs 


\section{RPP-RPT-31293, Rev. 0}

RPP-PLAN-28509

D R A F T

Figure 1. Unknown Crystalline Structure.

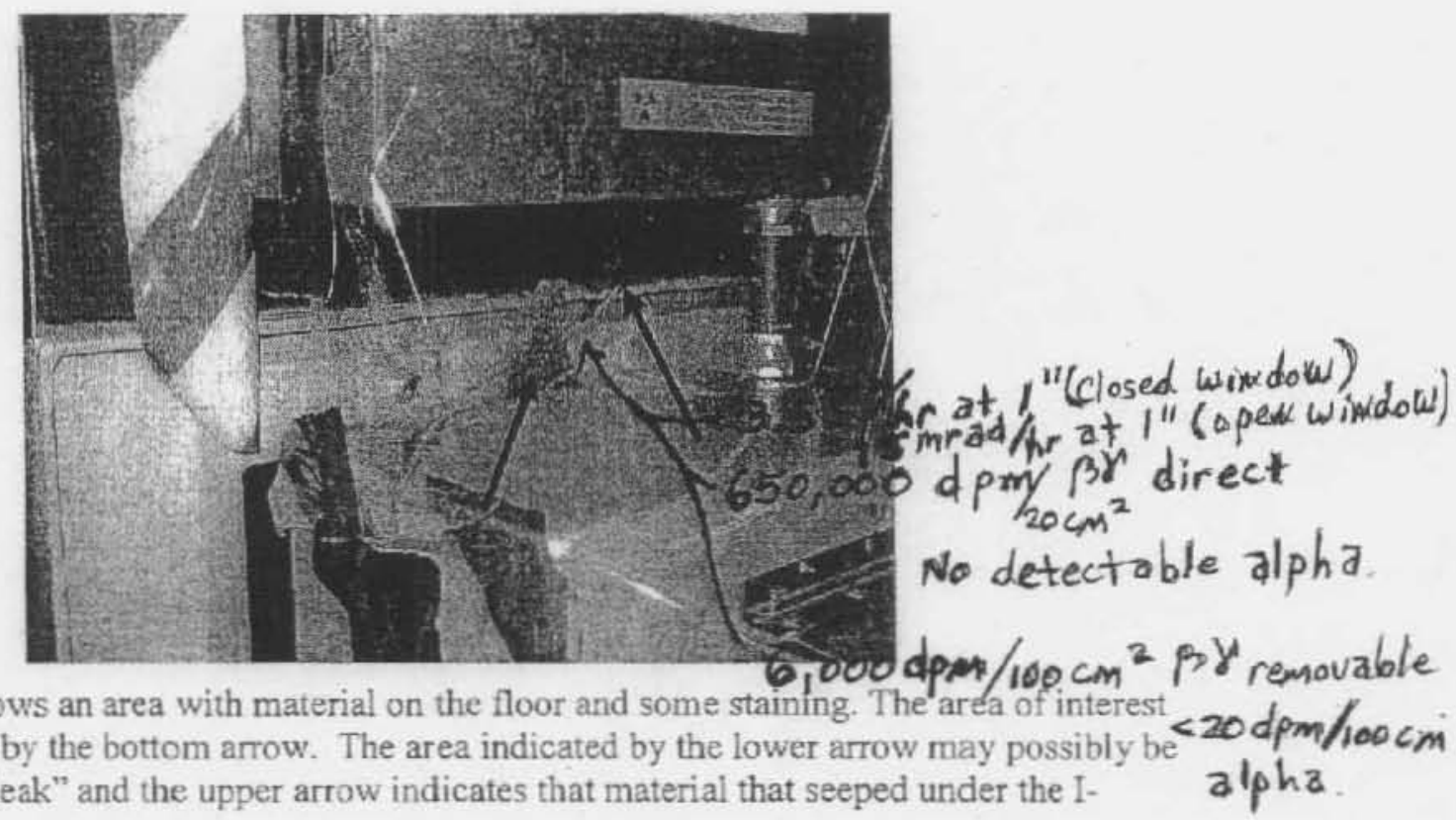

Figure 2 shows an area with material on the floor and some staining. The area of interest is indicated by the bottom arrow. The area indicated by the lower arrow may possibly be the initial "leak" and the upper arrow indicates that material that seeped under the Ibeam.

Figure 2. Unknown Floor Stain.

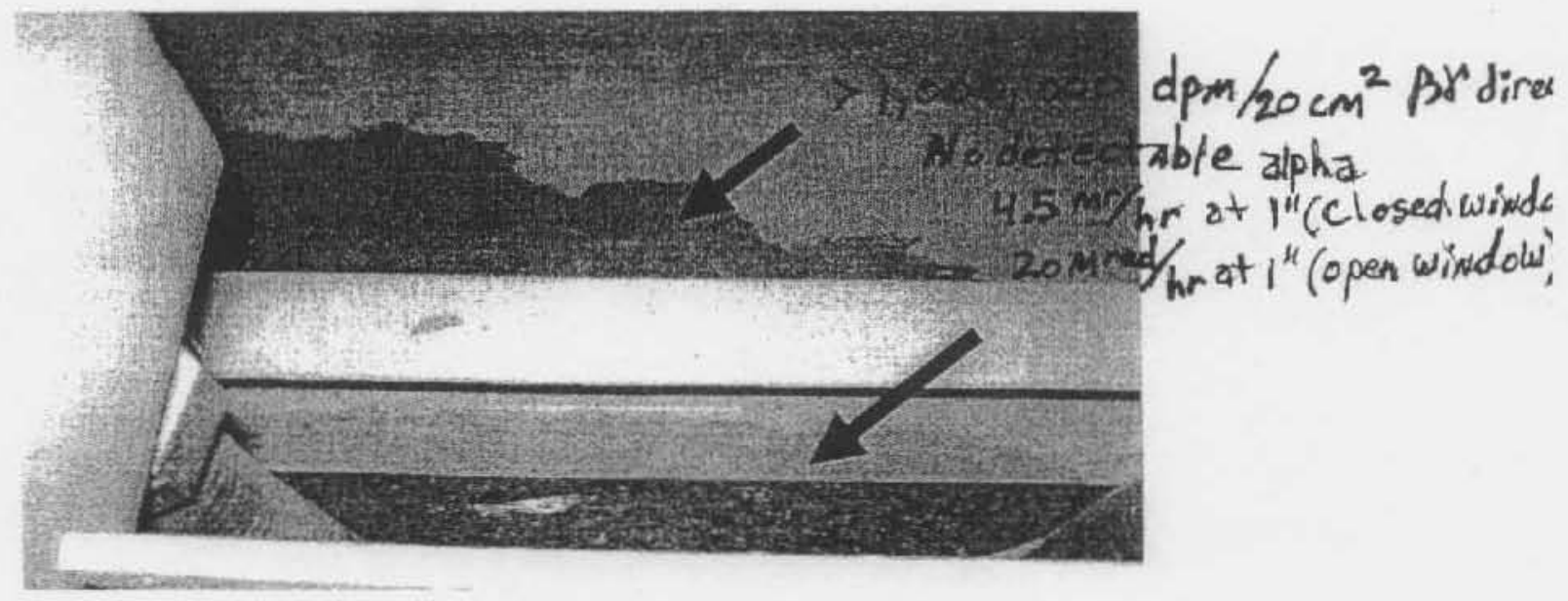

\subsection{Physical Description}

The 702-AZ ventilation system services the vapor space for four tanks, namely tanks 241-AY-101, 241-AY-102, 241-AZ-101 and 241-AZ-102. The 702-AZ ventilation system includes three buildings: a ventilation building, a generator/service building, and a contral buiiding. It also includes four recirculation/cooling cells. The 702-AZ ventilation system provides a maximum $28.3 \mathrm{~m}^{3} / \mathrm{min}$ (1000 scfm) flow from the four 
RPP-RPT-31293, Rev. 0

RPP-PLAN-28509

D R A F T

The 702-AZ ventilation system provides a maximum $28.3 \mathrm{~m}^{3} / \mathrm{min}(1000 \mathrm{scfm})$ flow from the four tanks $\left(2.83 \mathrm{~m}^{3} / \mathrm{min}\right.$ [100 scfm] nominal from each tank). The structures are of independent construction. The area of concern is Filter Room A located in Building 702$\mathrm{AZ}$ as shown in Figure 3.

Figure 3. 702-AZ Ventilation Building.

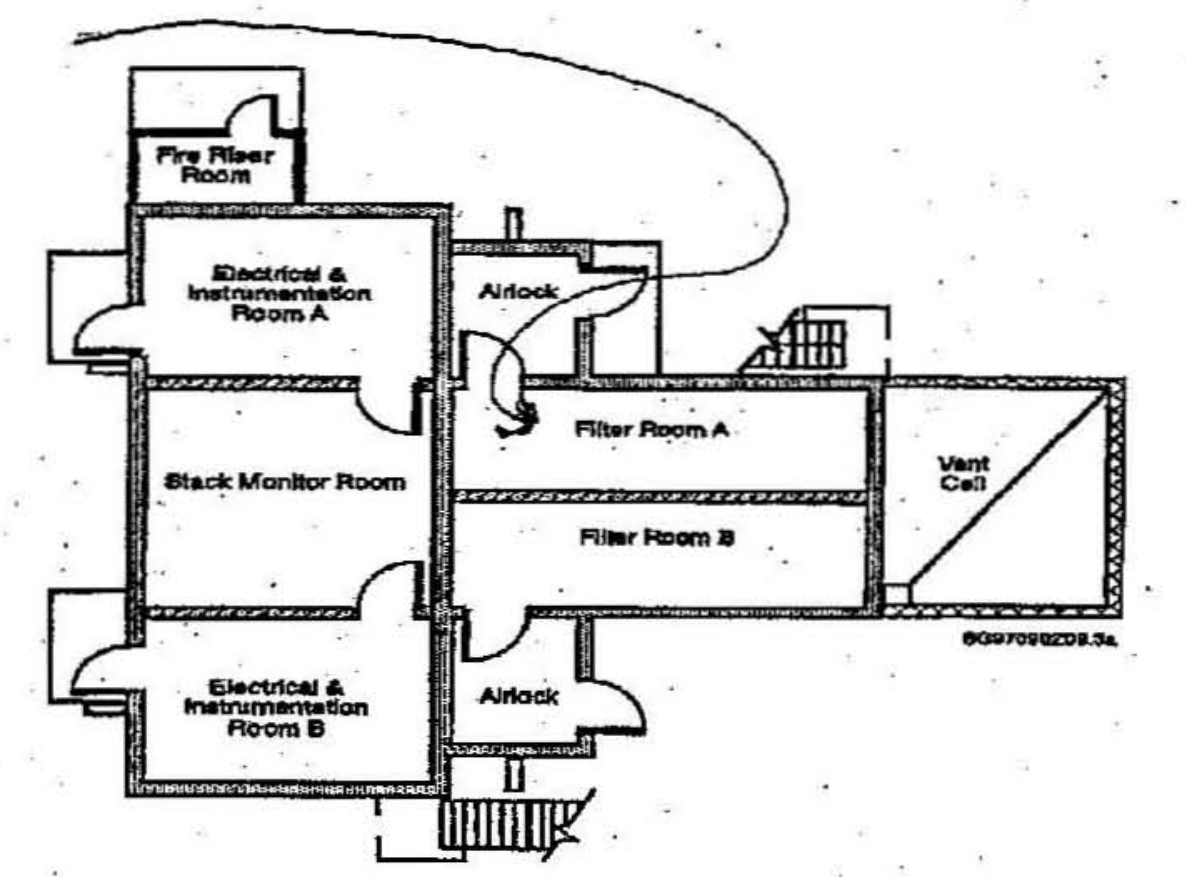

The 702-AZ ventilation system is sized such that a negative differential pressure with respect to atmospheric pressure can be maintained under normal operating conditions to contain radioactive and non-radioactive gases, vapors, suspended droplets, and airborne particulates within the system until appropriately treated and discharged.

Exhaust air from the primary tank system is treated to minimize releases of radioactive and hazardous effluents to the atmosphere. The filtered airstream is continuously sampled for gross beta and gamma. Instruments record and alarm before allowable radioactive release limits are exceeded.

Water vapor removed from the tanks is condensed, and the condensate is returned to AY or AZ high heat tanks. 
RPP-RPT-31293, Rev. 0

RPP-PLAN-28509

D R A F T

\subsection{List of Contaminants of Potential Concern}

Contaminates of potential concern are:

- Biological

- Radiological

- Hazardous chemicals

- Polychlorinated biphenyls

More specifically a list of radionuclides and non-radionuclides was generated in the Tank Waste Remediation System Basis for Interim Operation (HNF-SD-WM-BIO001 REV 0-D) for the 702-AZ exhaust train. Although this BIO has been superseded, the follow on safety authorization documents do not discuss the tank chemistry as does the BIO. For the chemistry references, the BIO is included in this Sampling and Analysis PLan (SAP). Tables 1 through 3 show the generated radionuclides and chemicals.

Table 1. Tank Waste Liquid Analyte Concentrations ${ }^{*}$

\begin{tabular}{|l|c|}
\hline \multicolumn{1}{|c|}{ Analote } & \multicolumn{1}{c|}{ Coticentration (gA } \\
\hline Ammonia (NH3) & $7.1 \mathrm{E}+00$ \\
\hline Antimony (Sb) & $6.4 \mathrm{E}-03$ \\
\hline Arsenic (As) & $1.1 \mathrm{E}-02$ \\
\hline Barium (Ba) & $3.3 \mathrm{E}-02$ \\
\hline Beryllium (Be) & $3.8 \mathrm{E}-03$ \\
\hline Cadmium (Cd) & $7.0 \mathrm{E}-02$ \\
\hline Calcium (Ca) & $1.3 \mathrm{E}+00$ \\
\hline Cerium (Ce) & $5.8 \mathrm{E}-02$ \\
\hline Cobalt (Co) & $8.8 \mathrm{E}-03$ \\
\hline Cyanide (CN) & $9.1 \mathrm{E}-02$ \\
\hline Lanthanum (La) & $1.0 \mathrm{E}+00$ \\
\hline Mercury (Hg) & $2.4 \mathrm{E}-04$ \\
\hline Neodymium (Nd) & $5.6 \mathrm{E}-03$ \\
\hline Selenium (Se) & $2.8 \mathrm{E}-01$ \\
\hline Sodium Hydroxide (NaOH) & $2.1 \mathrm{E}+02$ \\
\hline Tellurium (Te) & $2.7 \mathrm{E}-03$ \\
\hline Thallium (Tl) & $3.7 \mathrm{E}-02$ \\
\hline Total organic carbon (TOPC) & $4.0 \mathrm{E}+01$ \\
\hline Uranium (U) & $1.1 \mathrm{E}+01$ \\
\hline Vanadium (V) & $2.1 \mathrm{E}-01$ \\
\hline
\end{tabular}

The information in this table is from Van Keuren, J.C., and J.S. Davis, 1996, Toxic Chemical Considerations for Tank Farm Releases, WHC-SD-WM-SARR-01 1, Rev 2, Westinghouse Hanford Company, Richland, Washington. 
RPP-RPT-31293, Rey. 0

RPP-PLAN-28509

D R A F T

Table 2. Headspace Gas Composite Concentrations *

\begin{tabular}{|l|c|c|}
\hline \multicolumn{2}{|c|}{ Gas } & Worst Case Composite \\
\hline Acetonitrile & Concentration (ppmv) & Concentration-(mg/m $\left.\mathbf{m}^{3}\right)^{\text {cb }}$ \\
\hline Ammonia & 13 & 21.8 \\
\hline Benzene & 61,300 & 40,000 \\
\hline 1,3-Butadiene & 0.4 & 1.3 \\
\hline Butanol & 0.1 & 0.19 \\
\hline Dodecane & 58 & 164 \\
\hline 2-Hexanone & 45 & 296 \\
\hline Methylene chloride & 0.8 & 2.7 \\
\hline Nitrous Oxide & 2 & 22 \\
\hline Propanenitrile & 67,000 & $110 ; 000$ \\
\hline Tributyl phosphate & 5 & 11 \\
\hline Tridecane & 1 & 12 \\
\hline
\end{tabular}

The information in this table is from Van Keuren, J.C., and J.S. Davis, 1996, Toxic Chemical Considerations for Tank Farm Releases, WHC-SD-WM-SARR-011, Rev 2, Westinghouse Hanford Company, Richland, Washington.

${ }^{b}$ Based on worst case composites including slurry gas released.

'The conversion from ppmy to $\mathrm{mg} / \mathrm{m}^{3}$ assumes a temperature of $38^{\circ} \mathrm{C}\left(110^{\circ} \mathrm{F}\right)$ and a pressure of 740 Torr (0.1 MPA).

Table 3. In-Tank Concentrations for II Radionuelides Aging Waste Facility Liquids ${ }^{2}$

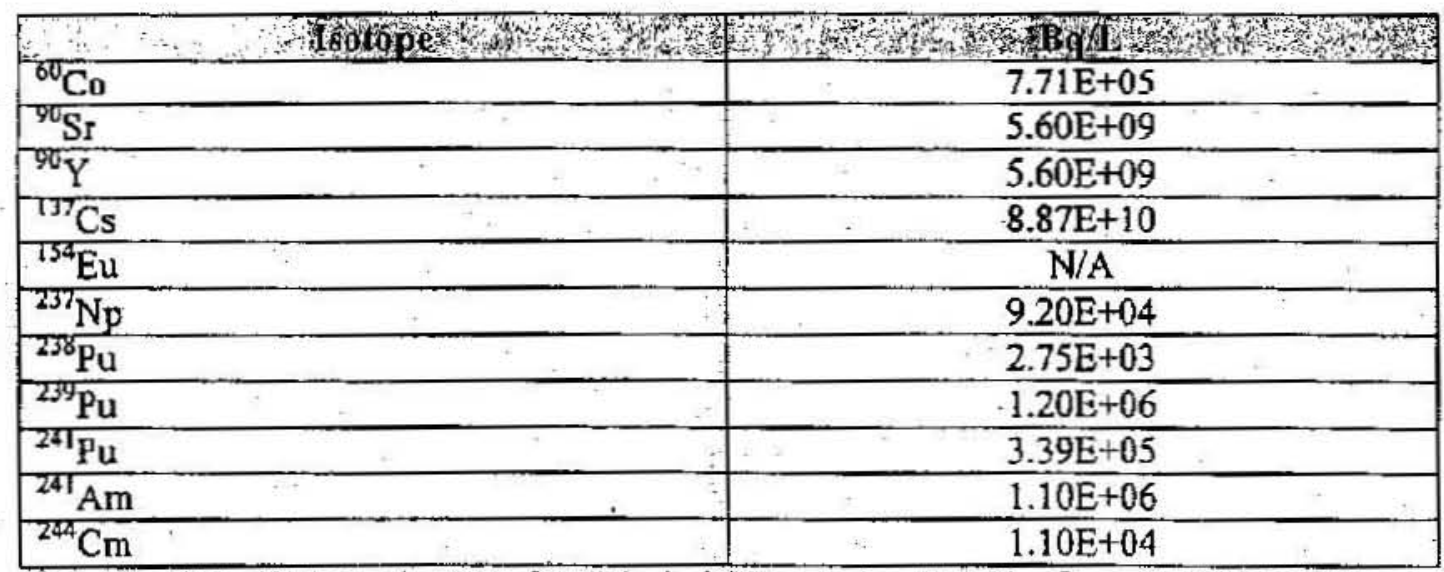

"Cowley, W.L., 1996, Development of Radiological Concentrations Unit Liter Doses for TWRS FSAR Radiological Consequence Calculations. WHC-SD-WM-SARR-037, Rev 0, Westinghouse Hanford Company, Richland, Washington. 


\section{RPP-RPT-31293, Rev. 0}

\section{RPP-PLAN-28509 \\ D R A F T}

\subsection{Problem Definition}

A health physics technician (HPT) while doing weekly routines in the 702-AZ Building, discovered that an HCA sign was posted across the walkway of the lower ' $A$ ' train side of the filter banks. Further investigation and smear surveys of the area enabled the reopening of the walkway and down posting back to the area of the stain and the crystalline mass. The observed 'crystalline' like substance, yellowish/brown in color, was growing above the heater control panel just below the heater. This is from an on-going leak from around the heater. There is also a large pool of a thick substance, like peanut butter mixed with oil, on the floor directly below the duct work where the heater is located. Both the crystal and the substance on the floor are contaminated to HCARA levels.

This building also possibly has a fungus growing with-in the condensate system. Green and black material was observed in the seal pot during the plugging issue investigation. The analysis of the condensate is beyond the scope of this SAP. It is unknown if possible fungi exist in the constituents on the floor and heater control panel. The material needs to be appropriately characterized for both chemical and biological components so that the cleanup and decontamination of the facility can be achieved.

\subsection{PROJECT ORGANIZATION and RESPONSIBILITIES}

Table 4 lists the individuals who will be the contact points for the sampling and analysis effort.

Table 4. Points of Contact

\begin{tabular}{|c|c|c|}
\hline $\begin{array}{l}\text { WFO Operations, point } \\
\text { of contact }\end{array}$ & WFO Operations & Bill Parnell, 373-5090 \\
\hline $\begin{array}{l}\text { WFO Engineering point } \\
\text { of contacts }\end{array}$ & WFO Engineering & $\begin{array}{l}\text { Andrew Templeton, } 373-5589 \\
\text { Bob Gustavson, 373-2615 }\end{array}$ \\
\hline $\begin{array}{l}\text { WFO Planning point of } \\
\text { contact }\end{array}$ & WFO Planning & - Dave Jorgensen, 373-6065 \\
\hline $\begin{array}{l}\text { Analys is of Biological } \\
\text { determinations }\end{array}$ & Microbiology, PNNL & $\begin{array}{l}\text { Fred Brockman, 376-1252 } \\
\text { Shu-Mei Li, 376-4023 }\end{array}$ \\
\hline $\begin{array}{l}\text { 222-S Laboratory point } \\
\text { of contact ( off hours) }\end{array}$ & Analytical Services & Laboratory Leader, $373-2435$ \\
\hline $\begin{array}{l}\text { 222-S Laboratory point } \\
\text { of contact Advanced } \\
\text { Technologies and } \\
\text { Laboratories } \\
\text { International, Inc. (ATL) }\end{array}$ & Analytical Services & Heather Anastos, 373-4629 \\
\hline $\begin{array}{l}\text { 222-S Laboratory } \\
\text { sample management }\end{array}$ & Sample Management Office, $\mathrm{POC}$ & John Prilucik ,373-3830 \\
\hline $\begin{array}{l}\text { Laboratory Technical } \\
\text { point of Contacts }\end{array}$ & Analytical Process Development, POC & $\begin{array}{l}\text { Jim Duncan, 373-1972 } \\
\text { Jann Frye, 376-8624 }\end{array}$ \\
\hline Samplers (Duratek) & $\begin{array}{l}\text { Duratek Field Services, Northwest } \\
\text { Operations }\end{array}$ & $\begin{array}{l}\text { Marty Gardner, } 372-8029 \\
\text { Jim Hogan, } 373-7063\end{array}$ \\
\hline
\end{tabular}


RPP-RPT-31293, Rev. 0

RPP-PLAN-28509

D R A F T

\subsection{SAMPLING OBJECTIVES}

Sampling will be directed to encompass the areas of biological, radionuclides, organic, and inorganic analyses. There will be two areas of analyses, the crystalline material and the brawnish-black material indicated by the bottom arrow in Figure 2 . Those samples, along with requisite blanks will comprise the sampling for $702 \mathrm{AZ}$ Train $\mathrm{A}$.

The following tables indicate sample or sample location, analysis, and analytes for the particular analysis. The biological analyses (Table 5) will be performed with the support of PNNL. The surface microbiological analyses (floor stain) will be performed using RODAC' plates. The RODAC ${ }^{\star}$ plates that will be used for general microbial counts and population will contain trypticase soy agar (TSA). Those RODAC ${ }^{\circ}$ plates used for fungi will contain Sabouraud dextrose agar (SAB). The agar plates will be returned to 222-S Laboratory incubated and a PNNL microbiologist will interpret the resulting growth. For the crystalline material, a known mass will be diluted in sterile phosphate buffer, serial dilutions will be made and a spread plate technique will be used to enumerate colony forming units at various dilutions to $1: 10^{5}$.

Table 5. Biological Analysis

\begin{tabular}{|c|c|c|}
\hline Sumple & W Analosis o 13 & 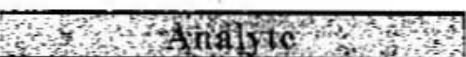 \\
\hline Crystalline Formation & $\begin{array}{l}\text { Microbiological total } \\
\text { population enumeration per } \\
\text { unit mass. }\end{array}$ & Bacteria / Fungi \\
\hline Floor Stain & $\begin{array}{l}\text { Microbiological surface } \\
\text { enumeration per unit area. }\end{array}$ & Bacteria/Fungi \\
\hline
\end{tabular}

Table 6 indicates the laboratory analyses to be performed. The table is divided into two sections; the primary analyses will be carried out on the samples from 702AZ. The secondary (optional) analyses may or may not be performed. The driver for the secondary'analyses will be the results of the microbiological testing and the primary analyses, and the decision by Tank Farms management as to the necessity to continue analyses.

Table 6. Analyses of Crystalline Material and Floor Stain

\begin{tabular}{|c|c|}
\hline Analysis & Analyte(s) \\
\hline GEA & $\begin{array}{l}\text { Radionuclide speciation (wil detail what } \\
\text { radioactive isotopes are present in the samples) }\end{array}$ \\
\hline $\begin{array}{l}\text { Scanning Electron Microscopy with } \\
\text { EDS }\end{array}$ & $\begin{array}{l}\text { Morphology, crystal identification and individual } \\
\text { constituents such as iron, etc. }\end{array}$ \\
\hline Polarized Light Microscopy & $\begin{array}{l}\text { Optical microscopy to gather crystalline phase } \\
\text { information }\end{array}$ \\
\hline
\end{tabular}

' $R O D A C$ is a registered trademark of B-D Laboratories, West Chester, Pennsylvania 
RPP-RPT-31293, Rev. 0

RPP-PLAN-28509

D R A F T

\begin{tabular}{|c|c|}
\hline X-ray Diffraction & $\begin{array}{l}\text { ldentification of compounds associated with the } \\
\text { crystalline mass }\end{array}$ \\
\hline Solid $\mathrm{pH}$ & $\mathrm{pH}$ of the samples. \\
\hline PCB Screen & $\begin{array}{l}\text { Necessary for the lab to properly dispose of waste from } \\
\text { analyses unless there is prior knowledge of sample } \\
\text { PCB content. }\end{array}$ \\
\hline+1 & onday dol $/ \mathrm{ses}$ \\
\hline $\begin{array}{l}\text { Water Digest followed by Ion } \\
\text { Chromatography }\end{array}$ & $\begin{array}{l}\text { Anions(fluoride, chloride, nitrite, nitrate, bromide, } \\
\text { phosphate, sulfate, formate, acetate, glycolate, oxalate) } \\
\text { in the water soluble fraction of the solid samples }\end{array}$ \\
\hline Acid Digest $/ \mathrm{ICP}$ & $\begin{array}{l}\text { Metal cations in the acid digested sample of the solids( } \\
\text { most metals except mercury) }\end{array}$ \\
\hline TICITOC & Total inorganic carbon and total organic carbon \\
\hline Organic Extract/GC-MS analysis & $\begin{array}{l}\text { Identification and quantification of organic soluble } \\
\text { organic compounds present in the solids. }\end{array}$ \\
\hline
\end{tabular}

\subsection{SAMPLING AND HANDLING METHODS AND REQUIREMENTS}

Personnel from Duratek will take the identified samples in accordance with approved sampling procedures or this sampling plan. The samples will be transferred to the laboratory by the sampling team where the samples will be analyzed for the constituents/parameters listed in Table 5 and the primary analytes in Table 6 .

\subsection{Sampling Locations}

The sampling locations will be the crystalline material, and brownish-black material within the $702-\mathrm{AZ}$ building.

\subsection{Sampling Equipment and Containers}

Sampling equipment and containers will be supplied by the 222-S laboratory and the PNNL microbiological laboratory.

\subsection{Sample Collection}

Duratek samplers will perform all sampling. The crystalline material will be separated from the exhaust ductwork in its natural state and placed into the sample containers. No liquid will be applied to the material. Hiofogical sampting will be carried out by

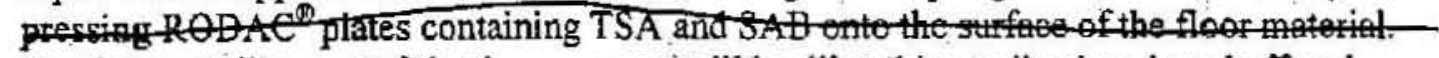
For the crystalline material, a known mass will be diluted in sterile phosphate buffered saiine (PBS), serial dilutions will be made and a spread plate technique will be used to enumerate colony forming units at various dilutions to $1: 10^{5}$.

The brownish-black material will be sampled in the vicinity of the area indicated by the lower arrow in Figure 2. A visually representative area will be selected and a sample will be taken in a $10 \mathrm{~cm}$ by $10 \mathrm{~cm}$ area. A scraper (plastic putty knife) will likely be tequired to collect a representative sample. For the microbiological surface samples, RODAC ${ }^{\circledR}$ plates containing TSA and SAB will be pressed on the surface of the stain. 
RPP-RPT-31293, Rev. 0

RPP-PLAN-28509

D R A F T

Table 7 addresses the sample collection.

Table 7. Sample Collection

\begin{tabular}{|c|c|c|c|c|}
\hline Item & Sample Number & $\begin{array}{l}\text { Type/Sample } \\
\text { Container }\end{array}$ & Analysis & Location \\
\hline \multicolumn{5}{|c|}{ Crystalline Material } \\
\hline $\mathrm{I}$ & $702-A Z-1$ & $\begin{array}{l}\text { Bulk/8 or } 16 \mathrm{oz} \\
\text { tared sterile } \\
\text { wide mouth jar }\end{array}$ & $\begin{array}{l}\text { SEM, PLM, X-Ray } \\
\text { Diffraction, GEA, } \\
\text { pH }\end{array}$ & $\begin{array}{l}\text { A-Train, below } \\
\text { heater }\end{array}$ \\
\hline 2 & $702-A Z-1 A$ & $\begin{array}{l}\text { Laboratory Plate } \\
\text { Counts }\end{array}$ & Bacteria, TSA & $\begin{array}{l}\text { A-Train, below } \\
\text { heater }\end{array}$ \\
\hline 3 & 702-AZ-1B & $\begin{array}{l}\text { Laboratory Plate } \\
\text { Counts }\end{array}$ & Fungi, SAB & $\begin{array}{l}\text { A-Train, below } \\
\text { heater }\end{array}$ \\
\hline \multicolumn{5}{|c|}{ Floor Stain Material } \\
\hline 4 & $702-A Z-2$ & $\begin{array}{l}\text { Bulk/8 or } 16 \mathrm{oz} \\
\text { tared sterile } \\
\text { wide mouth jar }\end{array}$ & $\begin{array}{l}\text { SEM, PLM, X-Ray } \\
\text { Diffraction, GEA, } \\
\text { pH }\end{array}$ & $\begin{array}{l}\text { A-Train, on floor } \\
\text { below heater }\end{array}$ \\
\hline 5 & $702-A Z-2 A$ & $\begin{array}{l}\text { RODAC Plate } \\
\text { w/TSA }\end{array}$ & Bacteria & $\begin{array}{l}\text { A-Train, on floor } \\
\text { below heater }\end{array}$ \\
\hline 6 & $702-A Z-2 B$ & $\begin{array}{l}\text { RODAC } \\
\text { w/SAB }\end{array}$ & Fungi & $\begin{array}{l}\text { A-Train, on floor } \\
\text { below heater }\end{array}$ \\
\hline \multicolumn{5}{|c|}{ Blanks } \\
\hline 7 & 702-AZ-TSA-BLK & $\begin{array}{l}\text { RODAC }{ }^{\infty} \text { Plate } \\
\text { w/TSA Blank } \\
\text { unopened }\end{array}$ & Bacteria & N/A \\
\hline 8 & 702-AZ-SAB-BLK & $\begin{array}{l}\text { RODAC }{ }^{\&} \text { Plate } \\
\text { w/SAB, Blank } \\
\text { unopened }\end{array}$ & Fungi : & $\overline{N / A}$ \\
\hline 9 & $\begin{array}{l}\text { 702-AZ-TSA- } \\
\text { FBLK }\end{array}$ & $\begin{array}{l}\text { RODAC Plate } \\
\text { w/TSA, Field } \\
\text { Blank }\end{array}$ & Bacteria & $\begin{array}{l}\text { A-Train, on floor, } \\
\text { clean area. }\end{array}$ \\
\hline 10 & $\begin{array}{l}\text { 702-AZ-SAB- } \\
\text { FBLK }\end{array}$ & $\begin{array}{l}\text { RODAC }{ }^{\infty} \text { Plate } \\
\text { w/SAB, Field } \\
\text { Blank }\end{array}$ & Fungi & $\begin{array}{l}\text { A-Train, on floor, } \\
\text { clean area }\end{array}$ \\
\hline 11 & $\begin{array}{l}\text { 702-AZ-TSA- } \\
\text { TRPBLK }\end{array}$ & $\begin{array}{l}\text { Petri Plate/PSB } \\
\text { w/TSA Trip } \\
\text { Blank } \\
\end{array}$ & Bacteria & $N / A$ \\
\hline 12 & $\begin{array}{l}\text { 702-AZ-SAB- } \\
\text { TRPBLK }\end{array}$ & $\begin{array}{l}\text { Petri Plate/PSB } \\
\text { w/SAB Trip } \\
\text { Blank }\end{array}$ & Fungi & N/A \\
\hline
\end{tabular}




\section{RPP-PLAN-28509 \\ D R A F T}

RPP-RPT-31293, Rev. 0

\subsection{QAVQC Samples}

\subsubsection{Primary Analyses}

Microbiological Analyses

For the crystalline material, microbiological sampling will consist of using a known mass and initially diluting 1:10 with sterile phosphate buffered saline (PBS). From this initial dilution, a series of dilutions will be made to achieve up to a dilution of $1: 10^{5}$. From each dilution, an aliquot will be spread onto agar plates (Petri dishes containing either TSA for bacterial enumeration or SAB for fungal enumeration) in three replicates each. Trip blanks (to ensure sterility of the PBS) will be run prior to and after completion of the spread plates.

For the floor stain material, RODAC ${ }^{\otimes}$ plates of each agar type will be used for surface contact determination of bacterial and fungal populations. RODAC ${ }^{38}$ plates of each agar type will be pressed against the floor stain and a second set of RODAC ${ }^{\$}$ plates will be pressed against the concrete inside the building in an area that appears "clean", these will act as field blanks.

Crystalline and Floor Stain Material 222-S Laboratory Analyses

A known mass of the samples (crystalline and floor stain) collected will be subjected to $\mathrm{pH}$, using the procedure $\mathrm{pH}$ Determination Of Solid Wastes, method (LA-212-105). The material will also be analyzed for PCBs using Screening Procedure For Polychlorinated Biphenyls (LA-523-141). A gamma energy analyses will be performed using the procedure Gamma Energy Analysis - The Genie $2 K$ System (LA-508-165). For quality control parameters see Table 8 .

The crystalline and floor stain material will also be analyzed using 1) scanning electron microscopy with electron dispersive spectroscopy using the procedure Sample Preparation and Operating Pracedure for Scanning Electron Microscopes (LT-161-100), 2) polarized light microscopy using procedure Polarized Light Microscopy (LT-519-107), and 3) X-ray diffraction (XRD) using the procedure X-Ray Diffractometry (LT-507-101).

\subsubsection{Secondary Analyses}

Should secondary analyses (Table 6) be deemed necessary, the 222-S Laboratory Quality Assurance Plan (HNF-SD-CP-QAPP-016) specifies the quality control parameters for primary analytes. ATL personnel operate to ATL Quality Assurance Project Plan for 222-S Laboratory (ATL-MP-1011).

Table 8 is extracted from the QAPP for those analyses identified in Table 6. 
RPP-RPT-31293, Rev. 0

\section{RPP-PL.AN-28509 \\ D R A F T}

Table 8. Quality Control Parameters for Primary Analytes

\begin{tabular}{|c|c|c|c|c|}
\hline \multirow[b]{2}{*}{ Analytes } & \multirow[b]{2}{*}{ Method } & \multicolumn{3}{|c|}{ QC Acceptance Criteria } \\
\hline & & $\begin{array}{c}\text { LCS } \\
\% \text { Recovery } \\
\end{array}$ & $\begin{array}{c}\text { Spike } \\
\% \text { Recovery }\end{array}$ & $\begin{array}{c}\text { DuplicatefAMSD } \\
\text { RPD }^{\mathbf{i}} \\
\end{array}$ \\
\hline $\begin{array}{l}\mathrm{Al}, \mathrm{Sb}, \mathrm{As}, \mathrm{Ba}, \mathrm{Be}, \mathrm{Cd} \\
\mathrm{Cr}, \mathrm{Co}, \mathrm{Cu}, \mathrm{Fe}, \mathrm{Pb}, \mathrm{Mn}, \\
\mathrm{Ni}, \mathrm{Se}, \mathrm{Ag}, \mathrm{Sr}, \mathrm{Tl}, \mathrm{U}, \mathrm{V}, \\
\mathrm{Zn}\end{array}$ & $\begin{array}{l}\text { ICPIAES } \\
\text { LA-505-158 }\end{array}$ & $80-120$ & $75-125$ & 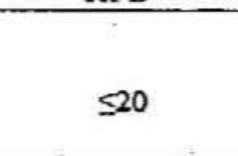 \\
\hline $\mathrm{F}, \mathrm{NO}_{2}, \mathrm{NO}_{3} ; \mathrm{NH}_{4}^{+}$ & $\begin{array}{c}\text { IC } \\
\text { LA- } 533-107\end{array}$ & $80-120$ & $75-125$ & 520 \\
\hline $\mathrm{OH}^{-}$ & $\begin{array}{c}\mathrm{pH} \\
\mathrm{LA}-212-105\end{array}$ & $\pm 0.1 \mathrm{pH}$ Units & NA & NA \\
\hline PCBs & $\begin{array}{c}\text { GCEECD } \\
1 \mathrm{~A}-523-141 \\
\end{array}$ & $70-130$ & $70-130$ & $\$ 30$ \\
\hline Inorganic Carbon & $\begin{array}{c}\text { TIC } \\
\text { LA-342-100 } \\
\end{array}$ & $80-120$ & $75-125$ & $\$ 20$ \\
\hline Organic Carbon & $\begin{array}{c}\text { TOC } \\
\text { L.A-342-100 } \\
\end{array}$ & $80-120$ & $75-125$ & $\leq 20$ \\
\hline${ }^{60} \mathrm{Co},{ }^{137} \mathrm{Cs}$ & $\begin{array}{c}\text { GEA } \\
\text { LA-508-165 }\end{array}$ & $80-120$ & NA & 520 \\
\hline${ }^{152} \mathrm{Eu},{ }^{154} \mathrm{Eu}^{1}{ }^{153} \mathrm{Eu}^{125} \mathrm{Sb}$ & $\begin{array}{c}\text { GEA } \\
\text { LA-508-165 } \\
\end{array}$ & NA & NA & $\leq 20$ \\
\hline $129_{1}$ & $\begin{array}{c}\text { GEA } \\
\text { LA-508-165 } \\
\end{array}$ & $80-120$ & NA & $\leq 20$ \\
\hline $\begin{array}{l}\text { Notes: } \\
\text { ICP/AES } \\
\text { IC } \\
\text { GC/ECD } \\
\text { TIC } \\
\text { TOC } \\
\text { GEA }\end{array}$ & $\begin{array}{l}\text { Inductively Cou } \\
\text { Ion Chromstogr } \\
\text { Gas Chromatog: } \\
\text { Total Inorganic } \\
\text { Total Organic C } \\
\text { Gamma Energy }\end{array}$ & $\begin{array}{l}\text { d Plasma / Atomic } \\
\text { hy } \\
\text { hy / Electron Capt } \\
\text { rbon } \\
\text { an } \\
\text { lalysis. }\end{array}$ & $\begin{array}{l}\text { nission Spectros } \\
\text { Detection }\end{array}$ & - \\
\hline
\end{tabular}

\subsection{Chain of Custody}

Sampling personnel will manage the collected samples in accordance with approved procedures. The sampling team will be responsible for initiating and maintaining the chain-of-custody from the time of sampling until custody transfer at the analytical laboratory. The Chain of Custody will serve as the primary document for all analytical requests. Copies of the chain of custody documentation will be provided with the laboratory data reports. Form A 6002-990, Generator Knowledge Information, will be submitted to help the lab deternine potential waste characteristics for disposal of unused samples after the final report is issued.

\subsection{Field Logbook}

A record of the sampling activities will be documented in a field logbook that is permanently bound, and has sequentially numbered pages. The field logbook entries will be made in accordance with approved procedures. The logbook will describe the general location of the sampling activity, type (matrix) of material sampled, sample method, sample source and specific location for each sample, sample number (corresponding to the sample label), weight of sample collected, date and time of sample collection, and any 


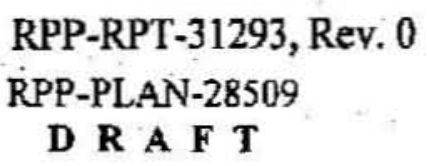

problems encountered or deviations from this SAP. The logbook will also identify all the sampling and handling procedure numbers and titles used in conjunction with the sampling activity (i.e. taking the sample, equipment cleaning, handling and chain-ofcustody, packaging and shipping, assigning sample numbers, etc.) Drawings, diagrams and photographs should be used when needed to clearly describe the sampling event. Each logbook entry will be signed and dated by the person making the logbook entry. Upon completion of the sampling project, a photocopy of the field logbook pages pertaining to the sampling activity will be included in the final sampling report.

Any problems encountered during sampling or major deviations from this SAP will be documented in the field logbook and communicated to the project manager as quickly as possible. Where a problem or deviation could affect the usability of the data, the sampling coordinator will contact the project manager and technical support personnel to determine the appropriate action to be taken (e.g., discontinue sampling, modify the sampling procedure, or continue sampling).

During the sampling campaign, any major deviations from this SAP will be reviewed and approved by the Engineering Point of Contact, the Laboratory Point of Contact and the WFO Planning Point of Contact. This SAP will be revised to reflect the changes and/or modifications by submittal of an addendum to the original document via e-mail, DSI, internal memo, or revision of the SAP.

\subsection{Sample Handling, Labeling and Shipping}

Following collection, samples will be packaged and shipped in accordance with approved procedures. Each sample will be identified and labeled with a unique sample number. Numbers will be assigned in accordance with approved procedures. The sample location and corresponding sample numbers will be documented in the field logbook.

\subsection{Additional Samples}

A material was encountered during the tie-in of the new line between AZ-702 and AZ301. The material was off white and was the described as slime. A piece of the pipe containing the material was set aside in a RMA for subsequent sampling. This material will be delivered to the laboratory separate from the 702-AZ A-train sampling and will also be analyzed for the primary analyses listed in Tables 7 and 8 .

Table 9. Biological Analysis of Internal Pipe Residue

\begin{tabular}{|l|l|l|}
\hline \multicolumn{1}{|c|}{ Sampile } & \multicolumn{1}{c|}{ Analysis } & Anduce \\
\hline Internal Pipe Residue & $\begin{array}{l}\text { Microbiological total } \\
\text { population enumeration. }\end{array}$ & Bacteria/Mold \\
\hline
\end{tabular}

Table 7 indicates the laboratory analyses to be performed. The table is divided into two sections; the primary analyses will be carried out on the samples from $702 \mathrm{AZ}$. The secondary (optional) analyses may or may not be performed. The driver for the secondary analyses will be the results of the microbiological testing and the primary analyses, and the decision by Tank Farms as to the necessity to continue analyses. 


\section{Subcontract 25499-19 SAMPLNG FOR BUILDING 241 702-AZ TRAIN A}

The purpose of this contract release is for the coordination and management of sample collection bottles or devices that meet the applicable chain of custody and sarmpling analysis form requirements, and if requested, sample collection both the crystalline material and the material on the floor in coordination with Tank Farm Contractor 702-AZ Train A.

A health physics techniciar (HPT) while doing weekly routines in the 702-AZ Building, discovered that an HCA sign was posted across the walkway of the lower 'A' train side of the filter banks. Further investigation and smear surveys of the area enabled the reopening of the walkway and down posting back to the area of the stain and the crystalline mass. The observed 'crystalline' like substance, yellowish/brown in color, was growing above the heater control panel just below the heater. This is from an on-going leak from around the heater. There is also a large pool of a thick substance, like peanut butter mixed with oil, on the floor directly below the duct work where the heater is located. Both the crystal and the substance on the floor are contaminated to HCARA levels.

This building also possibly has a fungus growing with-in the condensate system. Green and black material was observed in the seal pot during the plugging issue investigation. The analysis of the condensate is beyond the scope of this SAP. It is unknown if possible fungi exist in the constituents on the floor and heater control panel. The material needs to be appropriately characterized for both chemical and biological components so that the cleanup and decontamination of the facility can be achieved.

Personnel from Duratek will take the identified samples in accordance with approved sampling procedures or this sampling plan. The samples will be transferred to the laboratory by the sampling team.

The sampling locations will be the crystalline material, and brownish-black material within the 702-AZ building.

Duratek samplers will perform all sampling. The crystalline material will be separated from the exhaust ductwork in its natural state and placed into the sample containers. No liquid will be applied to the material. Microbiological sampling will be carried out by pressing RODAC plates containing TSA and SAB onto the surface of the floor material. For the crystalline material, a known mass will be diluted in sterile phosphate buffered saline (PBS), serial dilutions will be made and a spread plate technique will be used to enumerate colony forming units at various dilutions to $1: 10^{5}$.

The brownish-black material will be sampled in the vicinity of the area indicated by the lower arrow in Figure 2. A visually representative area will be selected and a sample will be taken in a $10 \mathrm{~cm}$ by $10 \mathrm{~cm}$ area. A scraper (plastic putty knife) will likely be required to collect a representative sample. For the microbiological surface samples, RODAC plates containing TSA and SAB will be pressed on the surface of the stain. 
RPP-RPT-31293, Rev. 0

INFORMATION TO SUPPORT THE ABOVE RELEASE

Estimated total cost is $\$ 5,000$.

Start is April 17, 2006 through September 30, 2006

Safety code is $\mathrm{F}$

CACN 502087

COA EJ00

Approvals are:

Andrew Templeton, Technical POC

Mark Wright, CAM for evaporator

Yousef Shehadeah, BTR for Blanket Master

Peggy Duvall, Cost Analyst 

A Train

\author{
J. B. Duncan \\ J. M. Fryc \\ CH2M HILL Hanford Group, Inc.
}

Date Published

Aprit 2006

\title{
- ch2miHLL \\ Hanlord Group, Ine.
}

Prepared for the US. Department of Energy

Office of River Protection

Contract No. DE-AC27-99RL14047

Approved for public relcast, distribution is unlimited 
RPP-RPT-31293, Rev. 0

RPP-PLAN-28509, REV. 0

TABLE OF CONTENTS

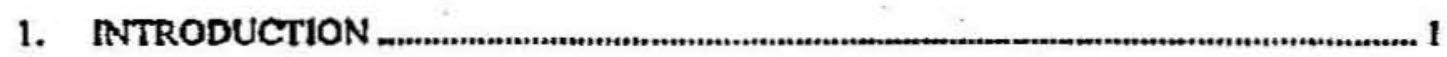

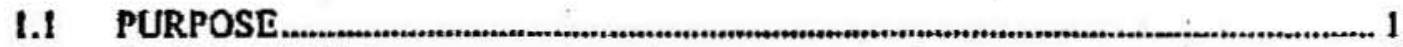

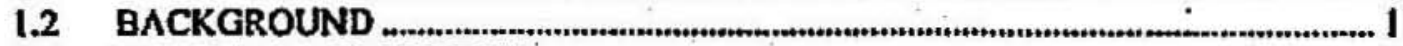

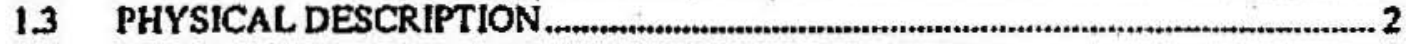

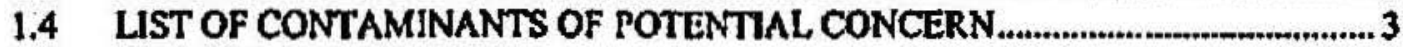

1.5 PROBLEM DEFINITION

2. PROJECT ORGANIZATION AND RESPONSIBILITIES _

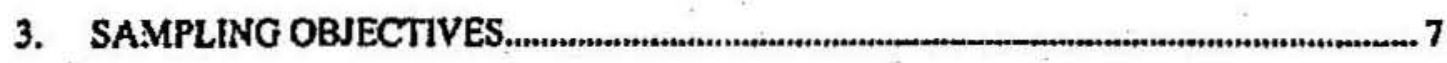

4. SAMPLING AND HIANDLING METHODS AND REQUIREMENTS .......................... 7

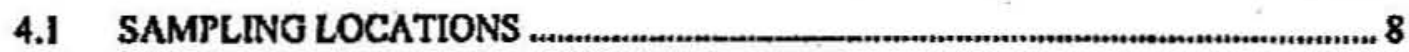

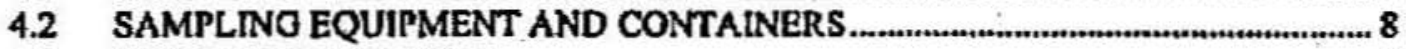

4.3 SAMPLE COLLECTION

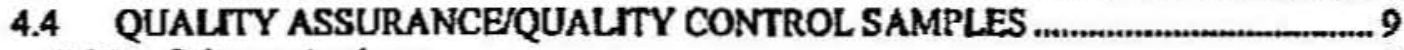

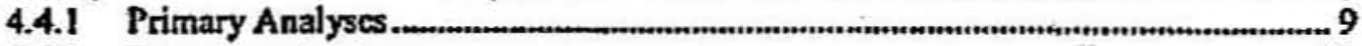

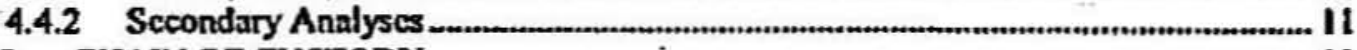

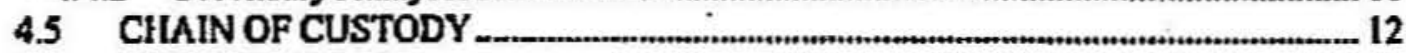

4.6 FIELD LOGBOOK

4.7 SAMPLE HANDLING, LABELING, AND SHIPPING ......................................... 13

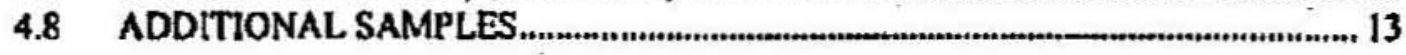

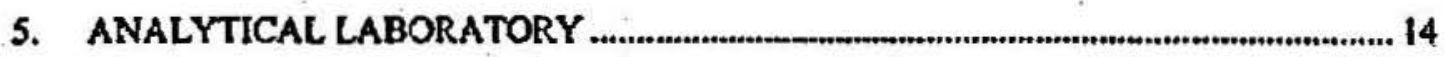

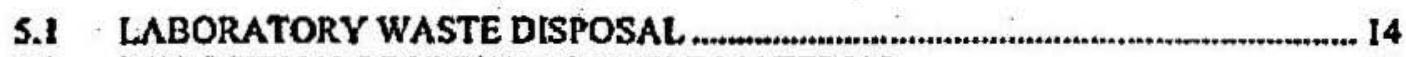

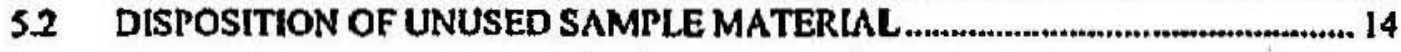

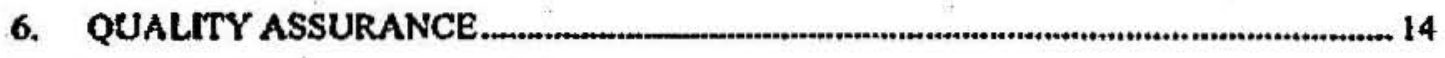

7. REFERENCES 
RPP-PLAN-28509, Rev. 0

\section{INTRODUCTION}

The 702-AZ A train has been obscrved to have brownish crystalline material of unknown origin emanating from an area below the exhaust heater and filter housing as well as a brownish-black material on the floor in close proximily to the fitter housing, also of unknown origin. The brownish-black material extends beneath the raised floor. Both materials are radioactively contaminated. The crystalline material and the floor stain may be related, and this sampling and analyses pian (SAP) will address both entities to answer PER-2004-6139, "702-AZ Filter Rooms Noed Radiological Clcanup Efforts, ${ }^{,}$in part. Based on historical information, this matcrial may be ammonium nitrate and/or sodium nitratc.

\section{t.1 PURPOSE}

The purposc of this SAP is to outline the key elements for sampling and analyzing both the crystalline material and the material on the floor.

\subsection{BACKGROUND}

The 702-AZ train is used to filter emissions from the ventilation of the primary tank headspaces in double-shell tanks 241-AY-101 (AY-101), 241-AY-102 (AY-102), 241-AZ-101 (AZ-101), and 24I-AZ-102 (AZ-102). When the 702-AZ ventilation system was first put into service in March of 1998, condensate build-up and flooding was cxpericaced throughout the $702 \cdot \mathrm{AZ}$ system. The A train was being operated at the time that flooding occurred. As a result of the event, the unit was shut down to remedy the problem, and therefore the 702-AZ paralle! B train was not exposed to the liquid. It was not immediatcly obvious that the high efficiency particulate air (FIEPA) filier on the A train was wet. When this was noted, the HEPA filters were changed on both Irains. The heater upstream of the HEPA filiers on the A train was found to be wet also, and the system was dried out as much as possible with rags. The presence of condensaic in the system and additional leakage appears to be intermittent and may be dependent on waste-intrusive work activity in the tanks, as well as the operational efriciency of the tank ventilation system moisturo removal subsystems.

In 2005, the condensate drainage and collection system was plugged in the drain from the seal pot to the catch tank. Efforts to investigate and clear drainage problems revealed that a construction test blank was left in place sinee 1998 in the drain from the system's primary condenser, which caused the condenser to fill up with condensate and spill over into adjoining ductwork. Additionally, oneration of tank ventilation recirculation loops has been intermittent, therefore contributing to high moisture content and resultant condensate in the system.

The same leakage problem is not apparent for the B train. Over the last 2 years B train has been operated more than A train. Figure 1 shows what appears to be a crystalline structure cmanating from a scam in the metal heater housing of the A train. Also, there appears to be corrosion along the same seam (right arrow). 
RPP-PLAN-28509, Rev. 0

Figure 1. Unknown Crystalline Structure.

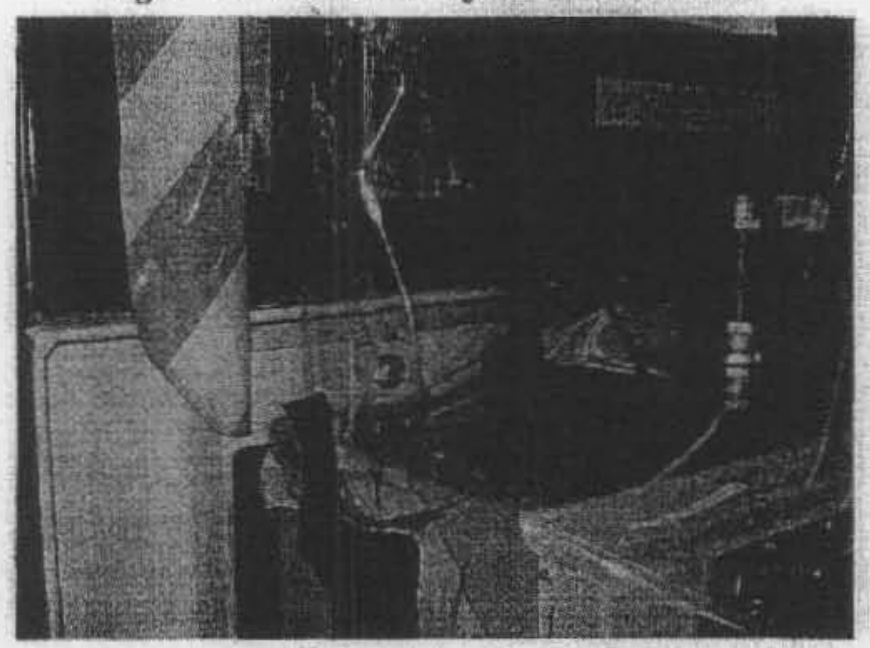

Figure 2 shows an area with material on the floor and some staining. The area of interest is indicated by the bottom arrow. The area indicated by the lower arrow may possibly be the initial "leak," and the upper arrow indicates material that seeped under the I-beam.

Figure 2. Unknown Brownish-black Material.

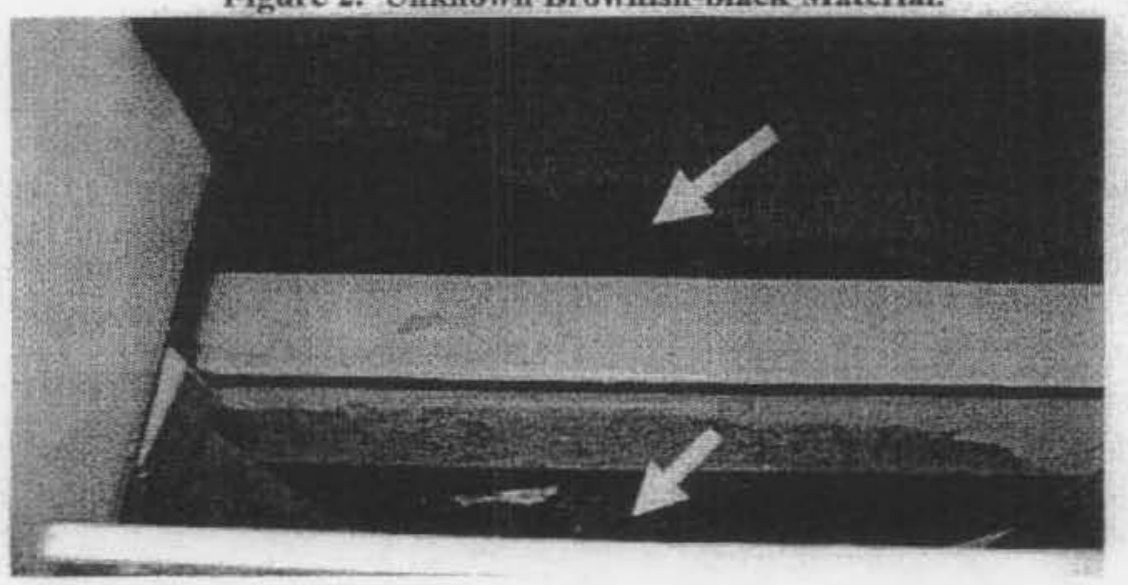

\subsection{PHYSICAL DESCRIPTION}

The 702-AZ ventilation system services the primary tank vapor space for four double-shell tanks: AY-101, AY-102, AZ-101, and AZ-102. The 702-AZ ventilation system includes three buildings: ventilation, generator/service, and control. It also includes four recirculation/cooling cells. The 702-AZ ventilation system provides a maximum $28.3 \mathrm{~m}^{3} / \mathrm{min}(1000 \mathrm{sefm})$ flow from the four tanks $\left[2.83 \mathrm{~m}^{3} / \mathrm{min}(100 \mathrm{scfm})\right.$ nominal from each tank]. The structures are of 
RPP-PLAN-28509, Rev. 0

independent construction. The area of concem is Filter Room $\mathrm{A}$ locatel in Building 702-AZ as shown in Figure 3.

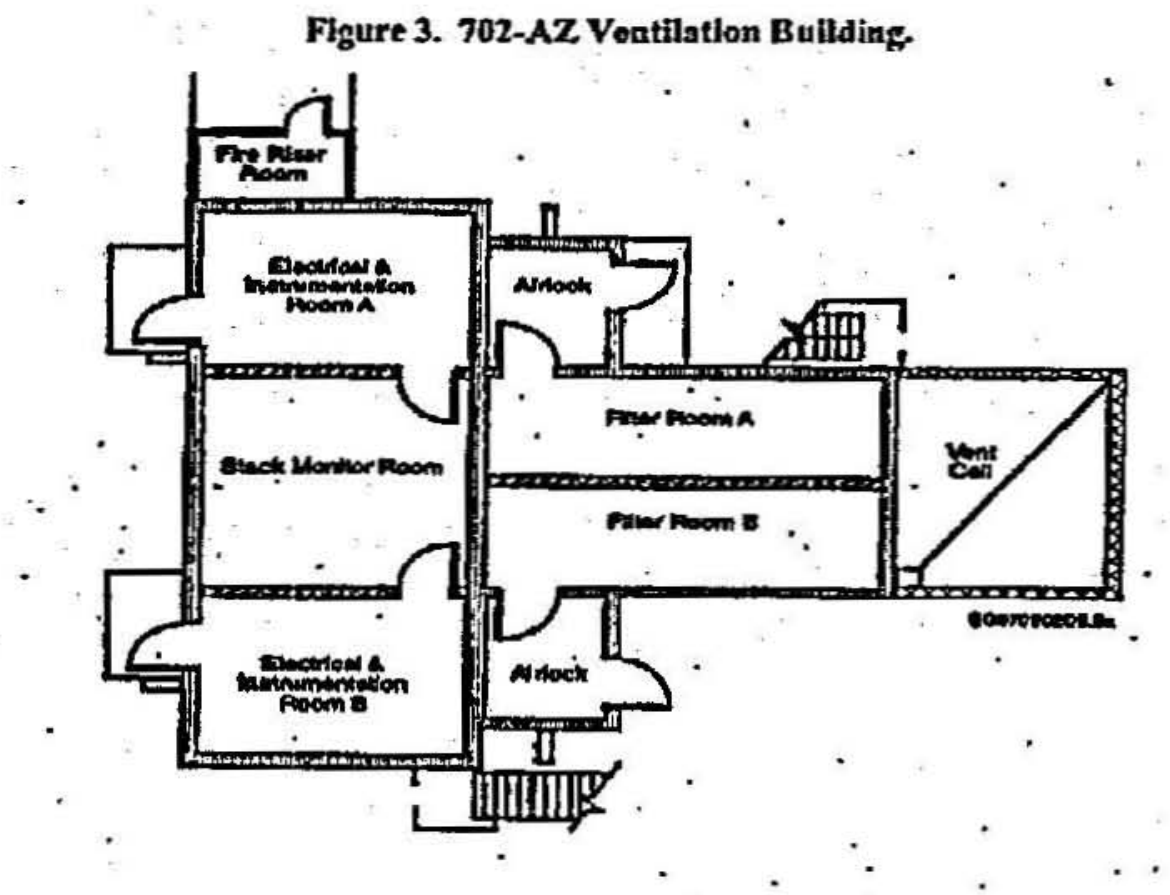

The 702-AZ ventilation system is sized such that a negative differential pressure with respect to atmospheric pressure can be maintained under normal operating conditions to contain radioactive and nonradioactive gases, vapors, suspended droplets, and airbornc particulates within the system until appropriately treated and discharged.

Exhaust air from the primary tank system is treated to minimize releases of radionctive and hazardous eflluents to the atmosphere. The filtered airstream is continuously sampled for gross beta and gamma. Instruments record and alarm before allowable radioactive release limits are exceeded.

Water vapor removed from the tanks is condensed, and the condensate is returned to $A Y$ or $A Z$ high heat tanks.

\section{I.A LIST OF CONTAMINANTS OF POTENTIAL CONCERN}

Contaminants of potential concern are

a. Biological.

b. Radiological.

c. Hazardous chemicals.

d. Polychlorinated biphenyls. 
More specifically a list of radionuclides and nonndionuclides was generated in HNF-SD-WM-BIO-001, Tank IVaste Remediation System Basis for Interim Opcration, for the 702-AZ exhaust train. Although this document was superseded, the follow-on safety authorization documents do not diseuss the tank chemistry as does HNF-SD-WM-B10-001. For the chemistry references, HNF-SD-WM-BIO-001 is included in this SAP. Tables I through 3 show the generated radionuclides and chemicals. No information is known about the biologieal makeup of the ventilation system condensate.

Table L. Tank Waste Liquid Analyte Concentrations.

\begin{tabular}{|c|c|}
\hline \multicolumn{2}{|c|}{ Concentration (o/L) } \\
\hline Analyte & Double-Shell Tank Lquids \\
\hline Ammonia $\left(\mathrm{NII}_{3}\right)$ & 7.1E+00 \\
\hline Antimony $\{$ Sb) & $6.4 E-03$ \\
\hline Arsenic (As) & I.IE-O2 \\
\hline Barium (Ba) & $33[-02$ \\
\hline Beryllium (Be) & $3.8 \mathrm{E}-0 \mathrm{3}$ \\
\hline Cadmium (Cd) & 7.0E-02 \\
\hline Calcium (Ca) & $1.3 E+00$ \\
\hline Cerium (Ce) & $5.85-02$ \\
\hline Cobait (Co) & $8.8 E-03$ \\
\hline Cyanide (CN) & 9.1E-02 \\
\hline Lanthanum (La) & $1.0 E+00$ \\
\hline Mencury (Ilg) & 2.4E-04 \\
\hline Neodyminum (Nd) & 5.6E-03 \\
\hline Selenium (Se) & 28E-01 \\
\hline Sodium hydruxide ( $\mathrm{NaOH})$ & $2.1 E+02$ \\
\hline Tellurium (Tt) & 2TE-03 \\
\hline Thallium (TI) & $3.7 \mathrm{E}-02$ \\
\hline Total organic carbon (TOPC) & $4.0 z+01$ \\
\hline Uranium (L) & $1.15+01$ \\
\hline Vanadium (V) & 2.IE-0I \\
\hline
\end{tabular}

Source. WIC-SD-WM-SARR-OII, Toric Chemical Considerations for Tank Farm Releases, 
RPP-PLAN-28509, Rev. 0

Table 2. Ilendspace Gas Composite Concentrations."

\begin{tabular}{|c|c|c|}
\hline \multicolumn{3}{|c|}{ Worst Case Composite } \\
\hline Cas & Concentration (ppmv) & Concentration (mg/n) $)^{\text {ol }}$ \\
\hline Acetonitrile & 13 & 21.8 \\
\hline Ammonia & 61,300 & 40,000 \\
\hline Benzerne & 0.4 & 13 \\
\hline 13-Butadictne & 0.1 & 0.19 \\
\hline Butanol & 58 & 164 \\
\hline Dodkcane & 4.5 & 296 \\
\hline 2-Ilexanonc & 0.8 & 2.7 \\
\hline Methylenc chloride & 2 & 22 \\
\hline Nitrous oxide & 67,000 & 110,000 \\
\hline Propancailrile & 5 & 11 \\
\hline Tributyl phosphisate & 1 & 12 \\
\hline Tridecane & 50 & 390 \\
\hline
\end{tabular}

"Sourcer WIIC-SO-WMSARR-0II.

Based on worrt-case composites iachuding alunry gas reteased.

"The conversion fiom ppriv lo mg/m sssumes a temperature of $38^{\circ} \mathrm{C}\left(110^{\circ} \mathrm{F}\right)$ and a prossure of 240 tort \{0.1 MPA\}.

Table 3. In-Tank Coneentrations for Eleven Radionuclides Aging Waste Facility Liquids"

\begin{tabular}{|c|c|}
\hline Fsotope & $\mathbf{B q} / \mathbf{L}$ \\
\hline${ }^{60} \mathrm{Co}$ & 7.71E+05 \\
\hline${ }^{0} \mathrm{Sr}$ & $5.60 E+09$ \\
\hline$x$ & $5.60 E+09$ \\
\hline${ }^{137} \mathrm{Cs}$ & $8.87 \mathrm{E}+10$ \\
\hline${ }^{154} \mathrm{Eu}$ & $N A$ \\
\hline${ }^{237} \mathrm{~N}_{\mathrm{p}}$ & $9.20 E+04$ \\
\hline${ }^{25} \mathrm{Pu}$ & 2.75E+03 \\
\hline${ }^{20} \mathrm{Pu}$ & $1.20 E+06$ \\
\hline${ }^{241} \mathrm{Pu}$ & $3.39 E+05$ \\
\hline${ }^{2011} \mathrm{Am}$ & $1.10 E+05$ \\
\hline${ }^{24} \mathrm{Cm}$ & $1.10 \mathrm{E}+04$ \\
\hline
\end{tabular}

"WHC-SD-WM-SARR-037, Drwlopinent of Rodiological Concentrations and Unil Liler Doses for TIFRS FSLR Rodialogical Consequence Calculations.

\subsection{PROBLEMI DEFINITION}

A Problan Evaluation Request (PER-2004-6139) was submitted after a health physics technician, while doing weekly routines in the 702-AZ Building, diseovered that a High Contamination Area (HCA) sign was postel across the walkway of the lower A-train side of the filter banks. Furher investigation and smear surveys of the aren enabled the reopening of the 
RPP-PLAN-28509, Rev. 0

walkway and down posting back to the erez of the stain and the erystalline mass. The observed 'crystalline'-like substance, yellowish/brown in color, was growing above the heater control panel just below the heater. This is the result of an ongoing leak from around the heater. $A$ large pool of a thick substance, like peanut butter mixed with oil, is also on the floor directly below the duct work where the heater is located. Both the crystal and the substanee on the floor are contaminated to HCA levels.

It is also stated in the PER that there is a possibility of fungus growing within the condensate system. Green and black matcrial was observed in the seal pot during the plugging issue investigation. It is unknown if possible fungi exist in the constituents on the floor and henter control pancl.

It does not visually appear that microbiological activity is present as mold or fungi; however, the erystalline and material located on the floor should be characterized for both chemical and biological components to enable cleanup and decontamination of the facility.

\section{PROIECT ORGANIZATION AND RESPONSIBILITIES}

Table 4 lists the individuals who will be the points of contact (POC) for the sampling and analysis cfort.

Table 4. Points of Contact.

\begin{tabular}{|c|c|c|}
\hline Responsibility & Organization/Function & Name / Phonc \\
\hline WFO Operations POC & WFO Operations & W. L. Parncll, 373-5090 \\
\hline WFO Enginecring POC & WFo Engineering & $\begin{array}{l}\text { A. M. Templeton, 373-5589 } \\
\text { R. D. Gustavson, 373-2615 }\end{array}$ \\
\hline WFO Planning POC & WFO Planning & D. M.Jorgensen, 373-6065 \\
\hline $\begin{array}{l}\text { Analysis of biological } \\
\text { determinations }\end{array}$ & $\begin{array}{l}\text { Microbiology, Pucific Northwest } \\
\text { National Laboralory (PNNL) }\end{array}$ & $\begin{array}{l}\text { F. J. Brockman, 376-1252 } \\
\text { S. W. Li, 376-402\} }\end{array}$ \\
\hline $\begin{array}{l}\text { 222-S Laboratory POC } \\
\text { (of hours) }\end{array}$ & Ansalytienal Services & Laboratory Leader, 373-2435 \\
\hline $\begin{array}{l}\text { 222-S Laboratory POC } \\
\text { Advanced Technologies } \\
\text { and Luboratories } \\
\text { Intemational, Inc. (ATL) }\end{array}$ & Analytieal Services & II. L. Anastos, 373-4629 \\
\hline $\begin{array}{l}\text { 222-S Laboratory sample } \\
\text { managcment }\end{array}$ & Sample Management Oflice & J.R. Prilucik, 373-3830 \\
\hline Leboratory Technical POC & $\begin{array}{l}\text { Analytical Process Development } \\
\text { (APD) }\end{array}$ & $\begin{array}{l}\text { J. D. Duncan, 373-1972 } \\
\text { J. M. Fryc, 376-8624 }\end{array}$ \\
\hline Samplers (Duratek) & $\begin{array}{l}\text { Duratek Federal Services of Ilanford, } \\
\text { Inc. Northwest Operations (Duratek) }\end{array}$ & $\begin{array}{l}\text { M. G. Gardner, 372-8029 } \\
\text { J. G. Ilogan, 373-7063 }\end{array}$ \\
\hline
\end{tabular}


RPP-PLAN-28509, REv. 0

\section{SAMIPLING OBJECTIVES}

The objective of sumpling the crystalline and the material located on the floor is to chameterize the materials for both chemical and biological componerts to cnable cleanup and decontamination of the facility. Sampling will be directed to encompass the arens of biologica!, radionuclides, physical, organic, and inorganic analyses. There will be two areas of analyses, the crystalline material and the brownish-black material indicated by the bottom arrow in Figure 2. Those samples aiong with requisite blanks will comprise the sampling for the 702-AZ A train.

The following tables indicate sample, analysis, and aralytes for the particular analysis. The biological analyses (Table S) will be performed with the support of Pacific Northwest National Laboratory (PNNL) (SOW 22490 release 102). The surface microbiological amalyses (brownishblack material located on the floor) will be performed using RODAC ${ }^{21}$ (Replieate Organism Delection and Counting) plates. The RODAC plates that will be used for general microbial counts and population will contain trypticase soy agar (TSA). Those RODAC plates used for fungi will contain Sabouraud dextrose ugar $(\mathrm{SAB})$. The agar plates will be returned to 222-S Laboratory, incubated, and a PNNL mierobiologist will interpret the resulting growth. For the crystalline material, a known mass will be diluted in sterile phosphate buffer, serial dilutions will be made, and a spread plate technique will be uscd to crumerate colony-forming units at various dilutions to $1: 10^{5}$.

Table 5. Biological Analysis.

\begin{tabular}{|l|l|l|}
\hline \multicolumn{1}{|c|}{ Sample } & \multicolumn{1}{|c|}{ Analysis } & \multicolumn{1}{c|}{ Analyte } \\
\hline Crystalline formation & $\begin{array}{l}\text { Mierobiological total population enumeration per unit } \\
\text { mass }\end{array}$ & Bacteria/fungi \\
\hline $\begin{array}{l}\text { Floor stain, brownish-black } \\
\text { material on floor }\end{array}$ & Mierobiological surface enumeration per unit ares & Bacteria/fungi \\
\hline
\end{tabular}

Table 6 indieates the Analytical Process Development (APD) and Advanecd Technologies and Laboratorics International, Inc. (ATL) laboratory analyses to be performed. The table is divided into two sections, the primary analyses will be carried out on the samples from 702-AZ. The secondary (optional) analyses may or may not be performed. The driver for the secondary analyses will be the results of the microbiological testing and the primary analyses, and the decision by tank farms manngement to proceed to the eccondary level.

\section{SAMPLING AND HANDLING METLODS AND REQUIREMENTS}

Personncl from Duratek will take the identified samples in accordance with approved sampling procedures and/or this SAP. The samples will be transferred to the laboratory by the sampling team where the samples will be analyzed for the constituents/parameters listed in Table 5 and the primary analytes in Table 6.

\footnotetext{
'RODAC ${ }^{\text {th }}$ is a registered tradenuark of B-D Laboratories, West Chester, Pennsylvanis.
} 
RPP-PLAN-28509, REV. 0

Table 6. Analyses of Crystalline Material and Floor Stain.

\begin{tabular}{|c|c|}
\hline \multicolumn{2}{|c|}{ Primary Analyses } \\
\hline Analysis & Analyte(g) \\
\hline Gamma energy analysis (GEA) & $\begin{array}{l}\text { Radiomuclide speciation (will describe radiowetive isotopes } \\
\text { present in the stamples) }\end{array}$ \\
\hline $\begin{array}{l}\text { Scanning electron mieroscopy (SEM) with } \\
\text { enerey disperslve X-ny spectroscopy (EDS) }\end{array}$ & $\begin{array}{l}\text { Morphology, erystal identification, and individual } \\
\text { constifecats sueh as inon, etc. }\end{array}$ \\
\hline Polarized light microscopy (PLM) & Optical microscopy to gather crystalfine phase information \\
\hline X-ray diffraction (XRD) & $\begin{array}{l}\text { Identificalion of eompounds assochated with the erystalfine } \\
\text { mass }\end{array}$ \\
\hline Solid pll & pll of the simples \\
\hline Polychlorinaied biphenyls (PCB) sereen & $\begin{array}{l}\text { Necessary for the lab to properly dispose of waste from } \\
\text { analyses unless there is prior knowlodge of asmple PCB } \\
\text { conical }\end{array}$ \\
\hline \multicolumn{2}{|c|}{ Secondary Analyses } \\
\hline $\begin{array}{l}\text { Water digest followed by ion chromatography } \\
\text { (IC) }\end{array}$ & $\begin{array}{l}\text { Anions (fluoride, chioride, natrite, nitrate, bromide, phosphate, } \\
\text { sulfake, formate, ecetate, plycolate, oxalate) in the water } \\
\text { soluble fraction of the solid sumples }\end{array}$ \\
\hline $\begin{array}{l}\text { Acid digest finductively coupled plasma } \\
\text { apeetroseopy (ICP) }\end{array}$ & $\begin{array}{l}\text { Metsl cations in the acid-digested smple of the solids (most } \\
\text { melals except mercury) }\end{array}$ \\
\hline Total inorganic carbon/lotal organic carbon & Total inorganic carbon and total organic carbon. \\
\hline $\begin{array}{l}\text { Organic extract/gas chromatography-muss } \\
\text { spectroecopy analysis }\end{array}$ & $\begin{array}{l}\text { Identification and quantification of organic soluble organic } \\
\text { compounds present in the salids }\end{array}$ \\
\hline
\end{tabular}

\subsection{SAMIPLING LOCATIONS}

The sampling locations will be the crystalline material and brownish-black material within Filier Room $A$ of the 702-AZ building. The crystalline material will be sampled in the area identified in Figure 1. The brownish-black material will be sampled in a representative area in the vicinity of Figure 2. The exact sample locations wilt be identified by one of the DST Maintenance and Engineering contacts.

\subsection{SAMPLING EQUIPMENT AND CONTAINERS}

Sampling equipment and enntainers will be supplied by the 222-S Laboratory and the PNNL microbiological laboratory.

\section{SABIPLE COLLECTION}

Duratck samplers will perform all sampling. The crystalline material will be scparated from the exhaust ductwork in its natural state and $5-10 \mathrm{~g}$ of the material will be placed into the sample containers. No liquid will be applied to the material.

The brownish-black material will be sampled in the vicinity of the area indicated by the lower arrow in Figure 2. The exact sampic locations will be identified by one of the DST Maintenanee 
and Enginecring contacts. A visually representative ares will be selected and a $2-5 \mathrm{~g}$ sample will be colleeted. A sterile scraper will be required to collect a representative sample.

For the microbiological surface sarnples, RODAC plates containing TSA and SAB will be pressed on the surface of the floor material in three selected locations. The cract sample locations wilt be identified by one of the DST Maintenanec and Engineering contacts.

Table 7 shows the sample numbers, sample lype, sample container, analysis, and location.

\subsection{QUALTTY ASSURANCE/QUALTY CONTROL SAMPLES"}

A set of RODAC plates will be unopened; these will act as laboratory blanks. Another set of RODAC plates will be pressed against the conercte inside the building in an area that appears "clean"; these will act as controls.

A set of Petri plates, one with TSA and one with SAB, will be provided as trip blanks and will leave the laboratory in the sample collection cooler and retum to the laboratory in the same cooler.

\subsubsection{Primary Analyses}

\subsubsection{Microbiological Analyses}

For the crystalline material, microbiological analysis will consist of using a known mass and initially diluting 1:10 with sterilc phosphatc buffered salinc (PBS). From this initial dilution, a series of dilutions will be made to nchieve up to a dilution of $1: 10^{5}$. From each dilution, an aliquot will be spread onto agar plates (petri dishes containing either TSA for baeterial enumeration or SAB for fungal enumeration) in three replieates each. Trip blanks (to cnsure sterility of the PBS) will be run prior to and affer completion of the spread plates.

For the floor stain material, RODAC plates of each agar type (TSA and SAB) will be used for surface contact determination of bacterial and fungal populations. RODACplates of each agar type will be pressed against selected area containing the floor stain. These samples will be collected in triplicate. A set of RODAC plates will be pressed against the concrete inside the building in an area that appears to be free from floor stain; these will act as controls. 
RPP-PLAN-28509, Rev. O

Table 7. Sample Collection.

\begin{tabular}{|c|c|c|c|c|}
\hline Lem & $\begin{array}{l}\text { Sample } \\
\text { Number }\end{array}$ & TypeSsample Container & Analyzls & Location \\
\hline \multicolumn{5}{|c|}{ Crystattine Misterbal } \\
\hline$T$ & $702-A 2-1$ & $\begin{array}{l}\text { Bullk/3-of } 16-0 z \text { thred } \\
\text { sterile wide-mouth jar }\end{array}$ & $\begin{array}{l}\text { SEM, PLM, XRD, GEA, } \\
\text { pII, becteris, fungus }\end{array}$ & A train, below heater \\
\hline 2 & $702 \cdot \mathrm{AZ} \cdot 1 \mathrm{~A}$ & Isboralory plate counts & Bacteria, TSA & $N / A$ \\
\hline 3 & $702-17.18$ & Loborntory plate corutsts & Fungl, SAB & $\mathrm{N} / \mathrm{A}$ \\
\hline \multicolumn{5}{|c|}{ Foor Stein Naterial } \\
\hline 4 & $702-\wedge Z 2.2$ & $\begin{array}{l}\text { Bulk/k- or 16-0z mared, } \\
\text { skrile wide-mouth jar }\end{array}$ & $\begin{array}{l}\text { SEM, PLM, XRD, GEA, } \\
\text { PI! }\end{array}$ & $\begin{array}{l}\text { A truin, on floor below } \\
\text { heater }\end{array}$ \\
\hline 5 & $702-\Lambda Z-2 A$ & RODAC plate w/TSA & Bacteria, TSA & $\begin{array}{l}\text { A train, on floor below } \\
\text { heater }\end{array}$ \\
\hline 6 & $702-12-2 B$ & RODAC plate w/SAB & Fungi, SAB & $\begin{array}{l}\text { A tritin, on foor below } \\
\text { heater }\end{array}$ \\
\hline 7 & $702-A Z 2 C$ & RODAC plate w/TSA & Bacteria, TSA & $\begin{array}{l}\text { A train, on floor below } \\
\text { heater }\end{array}$ \\
\hline 8 & $702-A Z-20$ & KOD $\wedge C$ plate w/SAB & Fungi, $\mathbf{S A B}$ & $\begin{array}{l}\text { A train, on lloor below } \\
\text { beater }\end{array}$ \\
\hline 9 & $702 \cdot A 2-2 E$ & RODAC plale wiTSA & Bacteria, TSA & $\begin{array}{l}\text { A train, on floor below } \\
\text { healer }\end{array}$ \\
\hline 10 & $702-12-28$ & RODAC plato w/SAB & Fungi, SAB & $\begin{array}{l}\text { A lrein, on foor below } \\
\text { heater }\end{array}$ \\
\hline \multicolumn{5}{|c|}{ Blanks } \\
\hline II & $\begin{array}{l}\text { T02-AZ-TSA- } \\
\text { BLK }\end{array}$ & $\begin{array}{l}\text { RODAC plaie w/TSA } \\
\text { blank unopened }\end{array}$ & Bacterla, TSA & N/A \\
\hline 12 & $\begin{array}{l}\text { 702-AZSSAB } \\
\text { BLK }\end{array}$ & $\begin{array}{l}\text { RODNC plate W/SAB, } \\
\text { blank mopened }\end{array}$ & Fungi, SNB & NA \\
\hline 13 & $\begin{array}{l}\text { 702-AZ-TSA- } \\
\text { FBLX }\end{array}$ & $\begin{array}{l}\text { RODAC plate wotS } \bar{h} \\
\text { field blank }\end{array}$ & Bacteria, TSA & $\begin{array}{l}\text { A train, on floor, clean } \\
\text { area }\end{array}$ \\
\hline 14 & $\begin{array}{l}\text { 702-AZ-SAB- } \\
\text { FBLK }\end{array}$ & $\begin{array}{l}\text { RODAC plate w/SAB, } \\
\text { field blank }\end{array}$ & Fungi, SAB & $\begin{array}{l}\text { A train, on floor, clean } \\
\text { irea }\end{array}$ \\
\hline 15 & $\begin{array}{l}\text { 702-AZTSA- } \\
\text { TRPBLK }\end{array}$ & $\begin{array}{l}\text { Petri plate } \mathrm{PSB} \text { w/TSA } \\
\text { trip blank }\end{array}$ & Dactcria & N/A \\
\hline 16 & $\begin{array}{l}\text { 702-AZ-SAB- } \\
\text { TRPBLX }\end{array}$ & $\begin{array}{l}\text { Petri plate/PSB w/SNB } \\
\text { trip blank }\end{array}$ & Fungi & N/A \\
\hline $\begin{array}{l}\text { GEA } \\
\text { PLM } \\
\text { SEM } \\
\text { XRD } \\
\text { TSA } \\
\text { SAB }\end{array}$ & 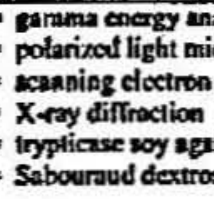 & $\begin{array}{l}\text { sis } \\
\text { scupy } \\
\text { crescopty }\end{array}$ & . & - \\
\hline
\end{tabular}

\section{4,4.1.2 Crystalline and Floor Staln Material 222-S Laboratory Analyses}

A known mass of the samples (crystalline and floor stain) collected will be subjected to pH, using the procedure LA-212-105, "pHI Determination of Solid Wastes," method. The material will also be annlyzed for PCBs using LA-523-141, "Sereening Procedure for Polychlorinated Biphenyls." A gamma energy analyses will be performed using the procedure LA-508-165, "Gamma Energy Analysis - The Genic 2K Systcm." For quality control parameters sec Table 8. 
RPP-PLLAN-28509, REv. 0

Table \&. Quality Control Parameters for Primary Analytes.

\begin{tabular}{|c|c|c|c|c|}
\hline \multirow[b]{2}{*}{ Analytes } & \multirow{2}{*}{ Miethod } & \multicolumn{3}{|c|}{ Quallity Control Aceeptance Criteria } \\
\hline & & $\begin{array}{c}\text { LCS } \\
\% \text { Recovery }\end{array}$ & $\begin{array}{c}\text { Splke } \\
\% \text { Recovery } \\
\end{array}$ & $\begin{array}{c}\text { Dupliente } / \text { SSD } \\
\text { RPD }^{\circ}\end{array}$ \\
\hline $\begin{array}{l}\mathrm{Al}, \mathrm{Sb}, \mathrm{As}, \mathrm{Ba}, \mathrm{Be}, \mathrm{Cd}, \\
\mathrm{Cr}, \mathrm{Co}, \mathrm{Cu}, \mathrm{Fe}, \mathrm{Pb}, \mathrm{Mn}, \\
\mathrm{Ni}, \mathrm{Se}, \mathrm{Ag}_{\mathrm{g}} \mathrm{Sr}, \mathrm{TL}, \mathrm{U}, \mathrm{V}, \\
\mathrm{Zn}\end{array}$ & $\begin{array}{l}\text { ICPIAES } \\
\text { LA-505-158 }\end{array}$ & $80-120$ & 75.125 & $\leq 20$ \\
\hline $\mathrm{F}, \mathrm{NO}_{2}^{-}, \mathrm{NO}_{3}^{-}, \mathrm{NIl}_{4}^{+}$ & $\underset{2 A-533-107}{1 C}$ & $80-120$ & $75-125$ & $\leq 20$ \\
\hline olt & $\begin{array}{c}\text { pll } \\
\text { LA-212-105 }\end{array}$ & \pm 0.1 pll units & NA & NA \\
\hline PCBs & $\begin{array}{c}\text { GCFECD } \\
\text { LA-523-141 }\end{array}$ & $70-130$ & $70-130$ & $\leq 30$ \\
\hline Inorganic carbon & $\begin{array}{c}\text { TIC } \\
\text { LA-342-100 }\end{array}$ & $80-120$ & $75-123$ & $\leq 20$ \\
\hline Orgaric carbon & $\begin{array}{c}\text { TOC } \\
\text { LA-342-100 }\end{array}$ & $80-120$ & 75.125 & $\leq 20$ \\
\hline${ }^{60} \mathrm{Co}_{4}{ }^{137} \mathrm{Cs}$ & $\begin{array}{c}\text { OEA } \\
\text { LA-508-165 }\end{array}$ & $80-120$ & NA & $\leq 20$ \\
\hline${ }^{112} \mathrm{Eu}_{2}{ }^{134} \mathrm{Eu},{ }^{113} \mathrm{Eu},{ }^{123} \mathrm{Sb}$ & $\begin{array}{c}\text { GEA } \\
\text { LA-508-165 }\end{array}$ & NA & NA: & $\leq 20$ \\
\hline$x_{1}$ & $\begin{array}{c}\text { OEA } \\
\text { LA-SO8-165 }\end{array}$ & 80.120 & NA & $\leq 20$ \\
\hline
\end{tabular}

\footnotetext{
Nowes:

CCIECD - gas chromatography/electron eaplure detection

OEA - garnma encryy enalyais

IC = ion chromatogrtphy

ICTIAES - Induetively coupled plasmajuxonic emistion ancetroscongy

MESD - matrix opileduplieate

RPD = relative pereent difirencos

TIC - total laorganic carbon

TOC = total organic carbon
}

"If primary und duplicate resulas are nvailable above detoction Iimils, RPD wilt be based on these results.

The crystalline and floor stain material will also be analyzed using (1) SEM with EDS using the procedure LT-161-100, "Sample Preparation and Operating Procedure for Scanning Elcctron Microscopes," (2) PLM using procedure LT-519-107, "Polarized Light Microscopy," and (3) XRD using the procedure LT-507-101, "X-Ray Diffractometry."

\subsubsection{Secondary Analyses}

Should secondary analyses (Table 6) be deemed necessary, HNF-SD-CP-QAPP-016, 222-S Laboratory Quality Assurance Plan (QAPP-016), specifies the quality control parameters for primary analytes. ATL personnel operate to ATL-MP-1011, ATL Quality Assurance Project Plan for 222-5 Laboratory. Table 8 is extracted from QAPP-016 for those analyses identified in Table 6. 
RPP-PLAN-28509, Rev. 0

\section{CIIAIN OF CUSTODY}

Sampling personncl will manage the collected samples in accordance with approved procedures. The sampling team will be responsible maintaining the chain of custody from the time of sampling until custody transfer at the analytieal laboratory. The chain of custody will serve us the primary document for all analytieal requests. Copies of the chain of eustody documentation will be provided with the laboratory data reports. Form A 6002-990, Gencrator Knowledge Information, will be submitted to help the lab determine potential waste charneteristies for disposal of unused samples after the final report is issued.

\subsection{FTELD LOGBOOK}

A record of the sampling activities will be documented in a field logbook that is permanently bound and has sequentially numbered pages. The field logbook entries will be made in accordance with approved procedures. The logbook will describe the general location of the sampling activity, type (matrix) of material sampied, sample method, sample source and specific location for ench sample, sample number (corresponding to the sample label), date and time of sample collection, and any problems encountered or deviations from this SAP. The logbook will also identify all the sampling and handling procedure numbers and titles used in conjunction with the sampling activity (i.e., taking the sample, equipment cleaning, handling and chain of custody, packaging and shipping, assigning sample numbers, etc.) Drawings, diagrams, and photographs should be used when needed to clearly deseribe the sampling event. Each logbook entry will be signed and dated by the person making the logbook entry. On completion of the sampling project, a photocopy of the field logbook pages pertaining to the sampling activity will be incleded in the final sampling report.

Any problems cncountered during sampling or major deviations from this SAP will be documented in the ficld logbook and communicated to the project manager as quickly as possible. Where a problem or deviation could affect the usability of the data, the samplers will contact the Laboratory Technical POC and/or the WFO Enginecring and Planning POC to detemine the appropriate action to be taken (c.g., discontinue sampling, modify the sampling procedure, or continue sampling).

During the sampling event, any major deviations from this SAP will be reviewed and approved by the POC for Enginecring, the Laboratory, and WFO Planning. This SAP will be revised to reflect the changes and/or modifieations by submittal of an addendum to the original document via e-mail, DSI, internal memo, or revision of the SAP. 
RPP-RPT-31293, Rev. 0

RPP-PLAN-28509, Rev, 0

\subsection{SANIPLE IIANDLIYG, LABELING, AND SIIIPPING}

Following collection, samples will be packaged and shipped in accordance with upproved procedures. Each sample will be identified and labeled with a unique sample number. Numbers will be assigned in accordance with approved procedures and this SAP. The sample lacation and corresponding sample numbers will be documented in the field logbook.

\subsection{ADDITIONALSAMPLES}

A material was encountered during the tie-in of the new line between AZ-702 and AZ-301. The material was off white and was deseribed as slime. A piece of the pipe containing the material was set aside in a Radioactive Material Area for subsequent sampling. This material was delivered to the laboratory and will be analyzed for the primary analyses listed in Tables 9 and 10 .

Table 9. Blological Analysis of Internal Pipe Residuc.

\begin{tabular}{|c|l|c|}
\hline Sampls & \multicolumn{1}{|c|}{ Analysis } & Analyte \\
\hline Internal pipe residuc & $\begin{array}{l}\text { Microbiological volal population } \\
\text { enumeration. }\end{array}$ & Bacteria/tungi \\
\hline
\end{tabular}

Tablelo is divided into two sections; the primary analyses will be carried out on the samples from AZ-301. The secondary (optional) analyses may or may not be performed. The driver for the secondary analyses will be the results of the microbiological testing and the primary analyses, and the docision by tank farms management as to the necessity to continuc analyses.

Table 10. Analyses of Internal Pipe Residuc.

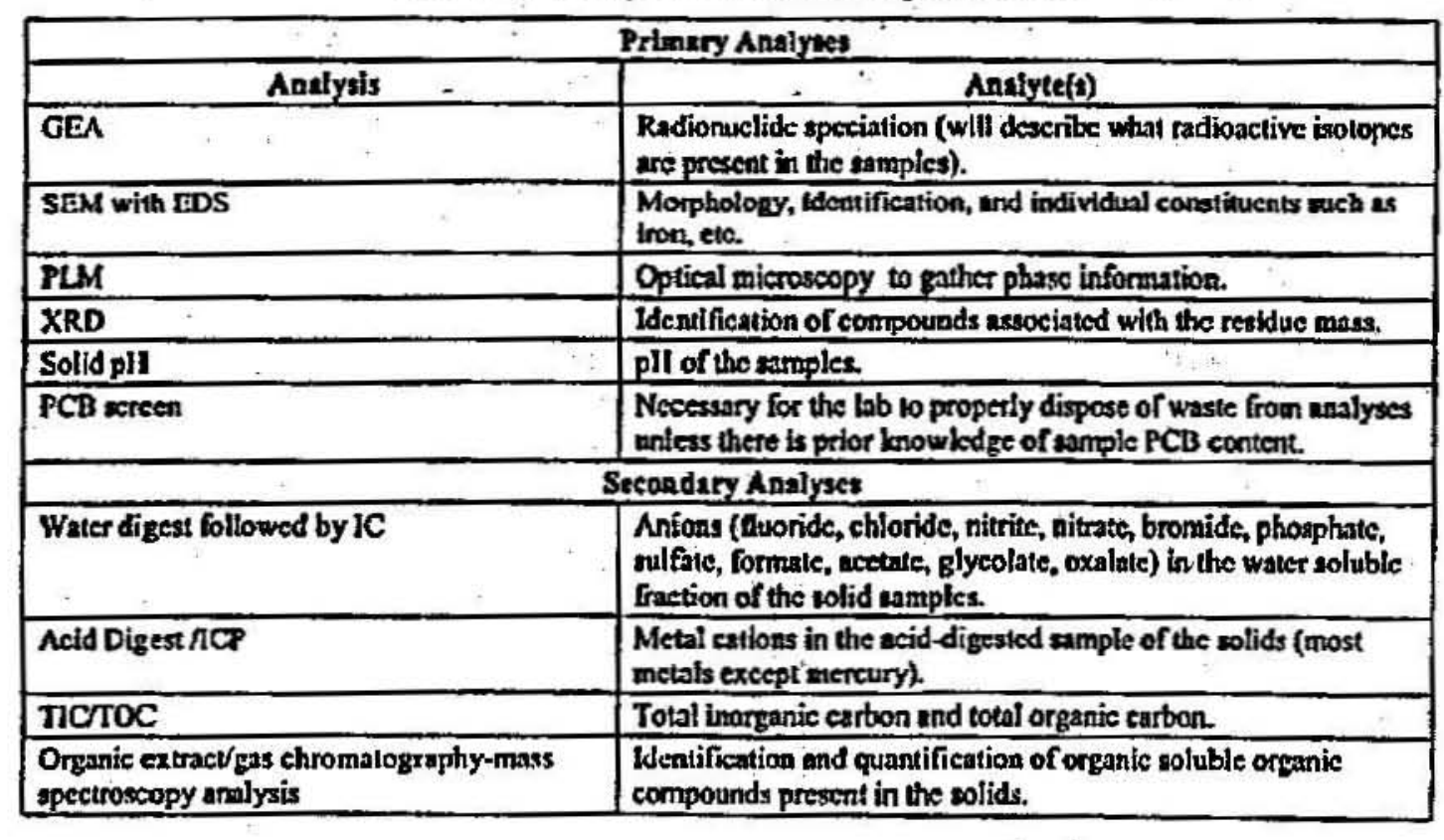




\section{ANALYTICAL LABORATORY}

All samples will be analyzed by 222-S Laboratory personncl, with the exception of the biological samples that will be analyzed at 222-S laboratory under the direction of a PNNL microbiologist.

The samples will be sent to the laboratory for the primary analyses as indieated in Table 5 and 6 . The following deliverables will be provided by the laboratory:

a. ATL will provide preliminary analysis results to APD within 60 days of sample receipt unless otherwise specified. Initial preliminary restalts will be provided as they are determined and will be transmitted via c-mail.

b. PNNL will provide preliminary analysis results via o-mail within SO days of sample receipt to APD. Also, PNNL will provide a final letter report under separate cover to DST Project and Maintenance Enginecting with 60 days of sample receipt.

c. APD will provide preliminary analysis results to DST Project and Maintenance Engineering within 60 days of sample receipt unless otherwise specified. Initia! preliminary results will be provided as they are delermined and will be transmitted via cmail.

d. ATL will provide the final analytical results with a quality assurance review and a list of the analytical procedures used to APD within 70 days of sample receipt unless secondary analyses are required.

c. APD will provide a final letter report to the DST Project and Maintenance Enginecring within 90 days of stmple receipt, to include a list of the procedures used, unless secondary analyses are required.

\subsection{LABORATORY WASTE DISPOSAL}

Any waste generated during the annlyses of samples will be disposed of in accorlance with ATS-LO-100-151, "ATS Laboratory Waste Generation."

\subsection{DISPOSTTION OF UNUSED SAMPLE MIATERIAL}

Final disposition of unused samples will be the responsibility of the 200 Area Surveillance and Maintenance Organization (200 Arca S\&M). Provided atl analyses are satisfactory, 200 Arca S\&M will pick up unused samples no longer than 30 days after receipt of final report. The Iaboratory can dispose of the unused samples in 60 days after reccipt of the final report.

\section{QUALITY ASSURANCE}

Sample collection, packaging, handling, and quality control shall be performed in accordance with the applicable requirements of DOE/RL-96-68, Hanford Analytical Services Quallty Assurance Requirements Document (HASQARD) as described in Duratek Federal Services, DFSW-QAM-001, Northwest Operations Quality Assurance Manual. 
RPP-RPT-31293, Rev. 0

RPP-PLAN-28509, Rev. 0

Sample analysis and laboratory quality control shall be performed in accordance with the applicable requirements of QAPP-016 and ATL-MP-1011.

Mierobiological analyses will be conducted according to the PNNL SOW 22490 release 102 and in aceordance with PNNL's Quality Assurance Program, which is implemented in the Standards Based Management System. The Quality Assurance Program is based on the requirements of DOE 0 414.1A, Quality Assurance, and ANSVASQ 21.13-1999, Quality Gutdelines for Rescarch.

\section{REFERENCES}

ANSVASQ Z1.13-1999, Quality Guidelines for Rescarch, Amcrican National Standards Institute, New York, Now York.

ATL-MP-1011, 2006, ATL Quality Assurance Project Plan for 222-S Laboratory, Rev. 2, Advanced Tectnologies and Laboratories International, Inc., Richland, Washington.

ATS-L0-100-151, Rev K-3, "ATS Laboratory Waste Gencration," CH2M HILLL Hanford Group, Inc., Richland, Washington.

DFSNW-QAM-001, Northwest Operations Quality Assurance Manual, Duratek Federal Services of Hanford, Ine., Richland, Washington.

DOE O 414.1A, 1998, Quality Assurance, U.S. Department of Encrgy, Washington, D.C.

DOE/R L-96-68, 1998, Ilanford Analytical Serviecs Quality Assurance Requirements Doctements, Revision 2, U.S. Department of Encrgy, Richland Operations Office, Richland, Washingion.

HINF-SD-CP-QAPP-016, 2005, 222-S Laboratory Quality Assurance Plan, Revision 9. CHI2M HILL. Hanford Group, Inc., Richland, Washington.

HNF-SD-WS-BIO-00I, 1998, Tank Waste Remediation System Basis for Interim Operation, Rev. 0, Lockhecd Martin HIanford Company, Richland, Washington.

LA-212-10S, Rev E-0, ".pH Determination of Solid Wastes, " CFI2M HILL Flanford Group, Inc., Richland, Washington.

LA-508-165, Rev B-0, "Gamma Encrgy Analysis - The Genic 2K System," Cl12M IIILL Hanford Group, Inc., Richland, Washington.

LA-523-141, Rev B-0, "Sereening Procedure for Polychlorinated Biphenyls," Cl12M HILL. Flanford Group, Ine., Richland, Washington. 
RPP-PLAN-28509, Rev. 0

LT-161-100, Rev C-0, "Sarmple Preparation and Operating Procedure for Scanning Electron Microscopes," CH12M HILL. Hanford Group, Inc., Richland, Washington.

LT-507-101, Rev D-0, "X-Ray Diffractometry," CI12M IILLL Ilanford Group, Inc., Richland, Washington.

LT-519-107, Rev C-D, "Polarized Light Microscopy," CH12M HLLL Hanford Group, Inc, Richland, Washington.

PER-2004-6139, "702-AZ Filter Rooms Need Radiological Cleanup Efforts," Ct12M HILL Hanford Group, Inc., Richland, Washington, dated December 15, 2004.

WHIC-SD-WM-SARR-011, 1996, Taxic Chemical Consldcrations for Tank Farm Releases, Rev 2, Westinghouse Hanford Company, Richland, Washington.

WHC-SD-WM-SARR-037, 1996, Development of Radiological Concentrations Unit and Liter Doses for TWRS FSAR Radiological Consequence Calculations, Rev 0, Westinghousc Hanford Company, Richland, Washington. 


\section{RPP-RPT-31293, Rev. 0 \\ Tank Farm Work Instruction \\ WFO-WO-05-000646 \\ 702-AZ Sampling Under Filter Housing}

\subsection{SCOPE}

- The scope of work is to perform sampling of the unknown substance on the concrete floor and crystal like material on the side and just beneath adjacent to the A-Train filter housing at 702-AZ building. The data obtained from this work order will be used to determine if a biological/chemical hazard exists.

- System Engineering has identified the equipment being worked on as GS.

\subsection{PRECAUTIONS AND LIMITATIONS}

[ ] 2.1. During the performance of this work package, normally inaccessible and potentially radiological highly contaminated areas will be exposed. An HPT shall be available to perform radiation/contamination surveys.

[ ] 2.2. Radiation protection measures to be determined by the Radiological Control Organization and hazardous material protection measures to be determined by the Safety and Health Organization.

I ] 2.3. This work package will be utilizing radiological limits and controis specified on RWP WTO-0022

\section{[ ] 2.4. RWP SAFE CONDITION LEVELS:}

- Notify SOM of conditions encountered and actions taken per the contingency plan.

- If any of the "Safe Condition Leveis" (WTO-0022) are detected or exceeded, the FWS will perform the following:

- FWS to stop normal work; place non-essential workers in a safe location as determined by HPT/FWS. HPT will attempt to locate the source of increased radiation or radioactivity levels and reduce to ALARA by installing shielding or wiping/decontaminating to below Safe Condition Level. 


\section{RPP-RPT-31293, Rev. 0 \\ Tank Farm Work Instruction \\ WFO-WO-05-000646 \\ 702-AZ Sampling Under Filter Housing}

- If levels cannot be reduced then the FWS shall instruct workers to place equipment in a safe configuration and evacuate the area.

.o FWS to notify shift manager.

[ ] 2.5. RSR numbers associated with this work shall be recorded on the RSR Log.

[ ] 2.6. Radcon has risk ranked this package to be Medium Risk.

\subsection{PREREQUISITES}

[1 3.1. Conduct a Pre-Job Briefing.

[ ] 3.1.1. FWS shall review applicable Lessons Learned, AMW, and RWP. Contingencies shall be identified and discussed during the pre-job briefing with all personnel assigned to the work activity.

[ ] 3.1.2. Ensure that the SSW is present at the pre-job.

[ ] 3.1.3. Ensure that the sample transport crew is at the Pre-Job and present at the work site.

[ ] 3.2. Prepare and Label (if needed) all sampling tools, containers, decontamination materials prior to taking them into the work area to enable effective release of equipment from HCAVCA.

[ ] 3.3. Stage all tooling including additional types of sample collection tools in or near the work area. 


\section{RPP-RPT-31293, Rev. 0 \\ Tank Farm Work Instruction WFO-WO-05-000646 \\ 702-AZ Sampling Under Filter Housing}

\subsection{SPECIFIC WORK INSTRUCTIONS}

[ 1 4.1. Set-up step off pad on the A-Train filter side at 702-AZ and ensure area is adequate for sampling.

[ ] 4.2. HPT perform baseline Pre-Job dose rate and removable contamination survey(s) of the work area and record RSR number.

[ ] 4.3. During collection of substance to be sampled IH\&S Technician shall conduct continuous vapor monitoring for organics and ammonia (any air changes for data points).

\section{Warning}

When reaching into HCA while laying on grating, workers should be aware of all hardware that may come in contact with PPE to ensure PPE will not become damaged during sample collection. (See Lessons Learned-L2001-OR-BJCPAD-0201)

\section{[ ] 4.4. Perform sampling per RPP-PLAN-28509 Sampling and Analysis Plan for Building 241 702-AZ Train A.}

[ ] 4.5. After samples are collected, prepare the samples for transportation to the anatytical lab using Chain of Custody process. HPT survey each sample container and approve release from HCAVCA.

[ ] 4.6. Dispose of sampling waste such as gloves and collecting devices per the Waste Planning Checklist.

\subsection{POST MAINTENANCE TESTING}

[ ] 5.1. Post-Maintenance testing is not required. 


\section{RPP-RPT-31293, Rev. 0 \\ Tank Farm Work Instruction \\ WFO-WO-05-000646 \\ 702-AZ Sampling Under Filter Housing}

\subsection{RESTORATION ACTIONS}

I 6.1 Job Site Cleanup

[ ]6.1.1. HPT perform Pre-clean-up removable contamination survey.

[ ] 6.1.2. Operator, decontaminate existing plastic covering and area as required.

[ ] 6.1.3. HPT perform post job radiation/contamination survey and document "as-left" conditions.

[ ] 6.1.4. FWS ensure that the job site has been cleaned up and equipment restored to as found condition.

[ ] 6.2. Natify the Shift Manager that the work is completed and restore the system per direction of shift manager. 


\section{GENERATOR KNOWLEDGE INFORMATION}

1. Chain of Cusiody Number $\mathrm{N} / \mathrm{A} \quad$ CACN/CCA S02087___ Customer identification Number 202-A.Z

2. List generator knowiedge or description of process thal produced sample. Or list description of sample source:

Material was found in the $702-\mathrm{A} 2$, A-train filter building. The material appears to be leaking from beneath the heater prior to the airstream entering the filters and has leaked onto the floor.

NSDS Avallabie? $O$ No $O$ Yes Hanford MSDS No.

3. List all waste codes and consilvenis associated with the waste or media that was sampled, rengardless of CERCLA status.

a) Does the sample contain any of the following listed waste codes?

By checking "unknown" the customer understands that no knowledge is avallable following a carefut saarch. List Federal Waste Code(s): List Constituent(s):
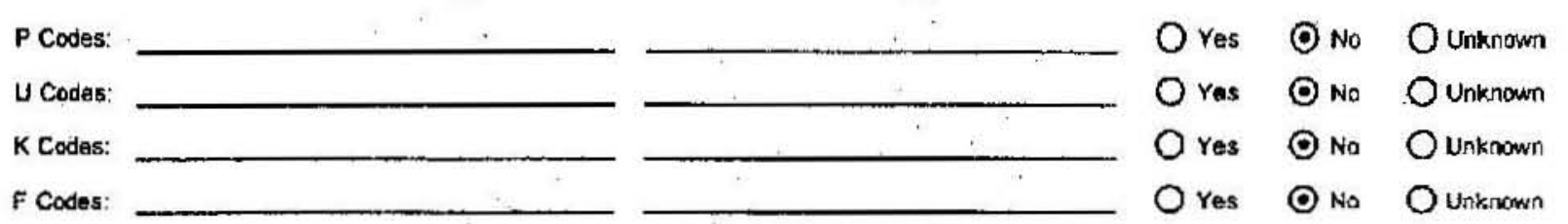

b) List applicable characderistic waste codes, flash point, $\mathrm{pH}$, constluents, and concentrations as appropriate.
D001: $\square \mathrm{FP}<100^{\circ} \mathrm{F}$
$\square \mathrm{FP} \geq 100<140^{\circ} \mathrm{F}$
$\square$ DoT Oxidizer
Y Yes
O No
(-) Unknown
D002: $\square \mathrm{pH} \leq 2$
$\square \mathrm{pH} \geq 12.5$
$\square$ solid Corrosive (USC2)
$O$ Yes
O no
C Unknown
D003: $\square$ Cyanide $\square$ sulfide $\square$ Water Reactive D004-D043 fidenify applicable wasta codes and concentrations):
$\square$ Other (1.e. peroxde tormer, Yes
O No
(C) Unknowa explosive, alr reactive)
Y Yes
(2) No
Unknown

c) If charecteristic, list any known underlying hazerdous consfituents (UHCS) reasonably expected to be present, and their concenirafions thai may be present abova the LDR treatment standard (4D CFR 268.48):

d) List any known Land Disposai Restrictions (LDR) subcategories, if applicatie (40 CFR 268.40)

e) List any applicable Washington State dangerous waste codes: (not required it

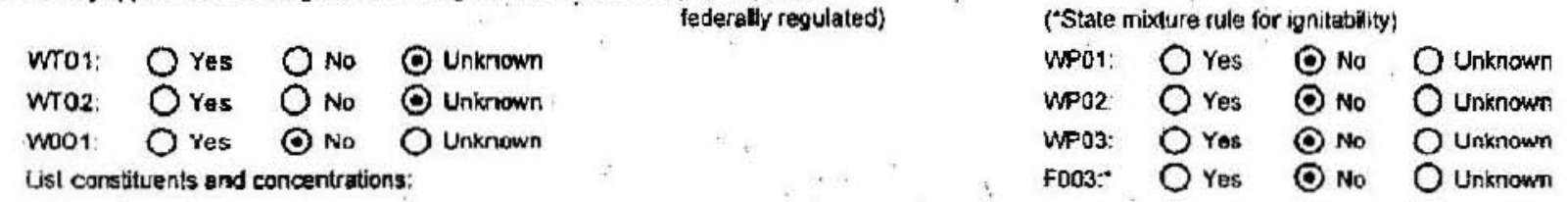

4. Is this material TSCA regulated for PCAs? $O$ yes $O$ No $O$ Unknown $O$ Analysis Requested

List concentration if applicable:

If yes, what is the source of the PCEs? (see TSCA PCB Hanford Site User Guide, DOE/RL-2001-50)

\begin{tabular}{|c|c|c|}
\hline asto & $\square$ PCB Buik Product Waste & $\square$ PCB Transformer $\geq 500 \mathrm{ppm}$ \\
\hline PCB Rernediation Waste & $\square$ PCB R\&D Waste & $\square$ PCB contaminated electrica! equipment (capacitorballast) $<500$ ppm \\
\hline D PCE Spill Materia! & $\square$ PCB ltem & $\square$ Other PCB Waste (tist) \\
\hline
\end{tabular}

5. Is this material TRU? $O$ Yes $O$ No $O$ Unknown

6. ACCURACY OF INFORMATION

Based on my inquiry of those individuals imuediately responsible for obtaining this inlomation, that to the best of my knowledge, the information

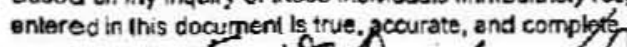

Print \& Sign EAN T. QRELE

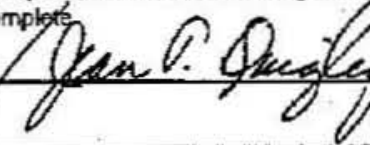
Date 


\section{BUSINESS SENSIIIVE

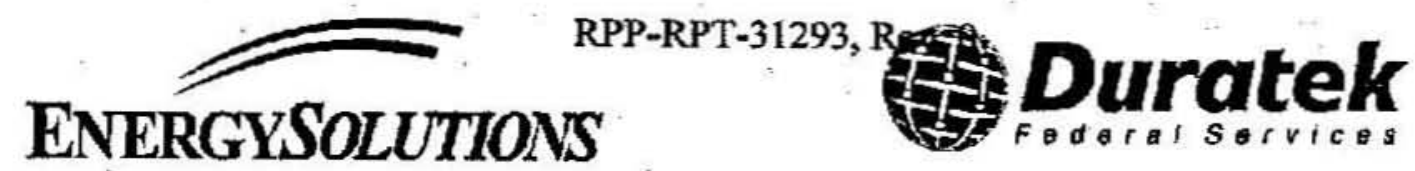

August 28, 2006

MAW-06-4514

A. M. Templeton

CH2M Hill Hanford S5.07

Post Office Box 1500

Richland, Washington 99354-1500

Dear Mr Templeton:

702AZ VENTILATION BUHLDING, 200 EAST AREA

Duratek Federal Services, Inc. completed the subject sampling event on July 31, 2006.

Attached for your records are copies of the Chain of Custody, sampling logbook entries and other associated documentation pertinent to the sampling tasks performed.

Thank you for the opportunity to be of service. If there are any questions, please contact me at 308-5721.

Very truly yours,

linton 217 agans

Victor L. Magnus

Sampling and Well Services

maw

Attachment

DTSNW - V. L. Magnus File/LB

RC6021 
RPP-RPT-31293, Rev. 0

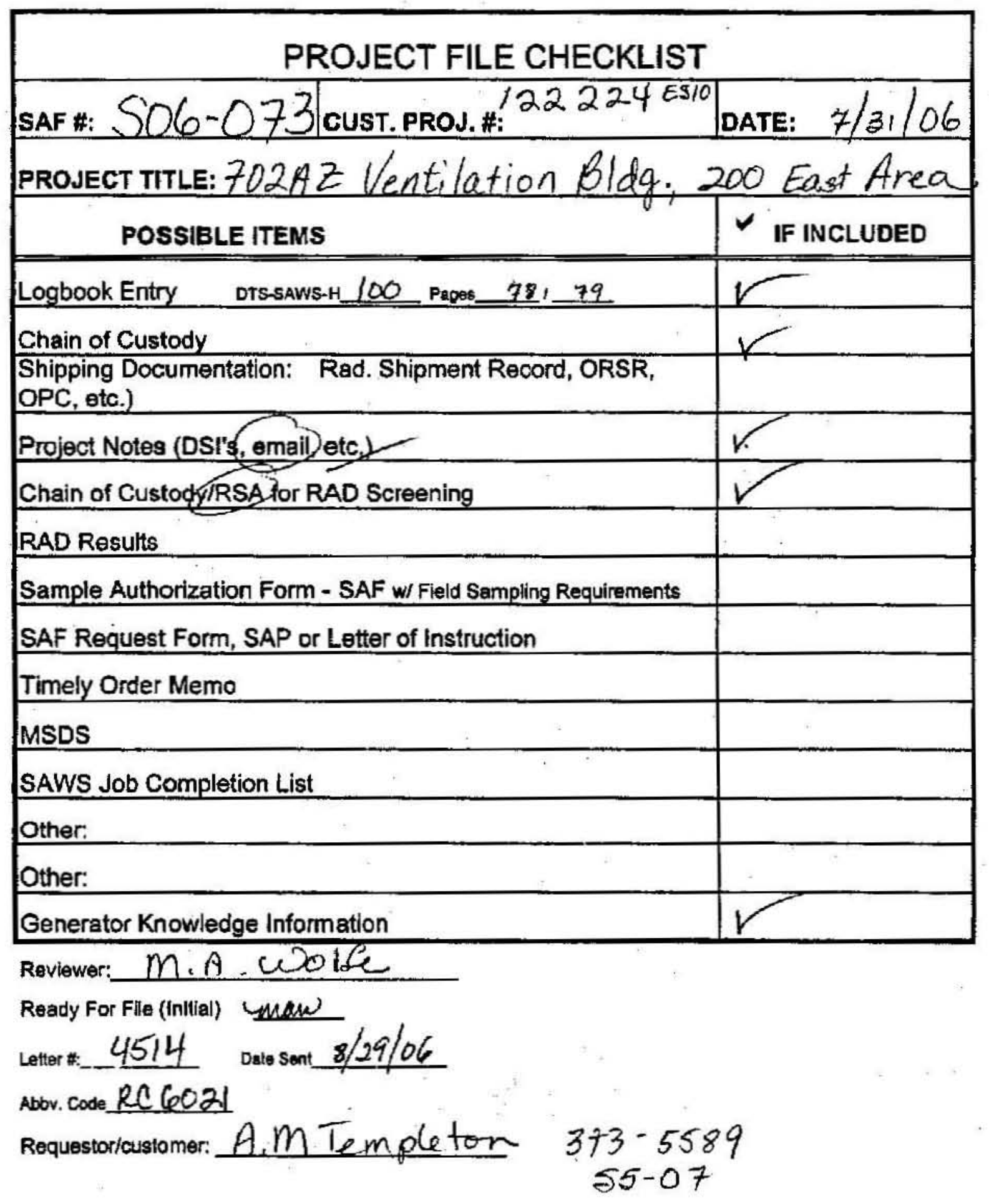

A- 67 
Page 93 of 162 of DA04063678

78

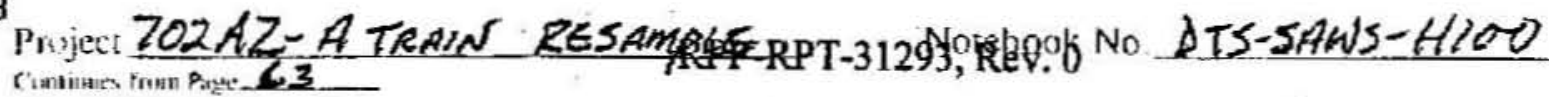

SAFE S06-073, 7-31-06 CHARAECOOE: IZZ224/ES1O

WORK DONE TO RCRA PROTOCOL

CATION: 702-AZ VENTILATION BUILDING, 200 EAST AREA

PErSONNEL: JG HoGAN

TR NEAR INA

CL KEARNEY

MI BUSTLE MAN

DA ANDERSON

RT WRIGHT

AM TEMPLETON
NCo/ sampler

NoO/CHa

Nico/citla

Noo/ctla

Hit

PIC

Customer $3.5589 \quad 55-07$

PaPpose: WASTE CHACACTERIZATION

RUT: WTO-022-REV 1

SAP RPP-ALAN-28509, REV

WORK PACKAGE: WFO-WOO-05-000646

PE: ONE SET ANTICS, APR, NITRIC GLOVES

SAMPLE EVENT: THE TAR LIKE MATERIAL UNDER THE 702-AZ " $A^{T}$ TRAIN WAS PREVIOUSLY SAMPLES ON 5-25-06 (SEE PAGES 57 -63 OF THIS LOABOOK). DUE TO A REQUEST From THE 222-S LAB, AN ADMTIONAL I0 GRAMS OF THE MATERIAL WAS NEEDED TO COMPLETE ALL OF THO ANGLTICAL REQUESTS.

SAMPLE METHOD: AN ENTRY WAS MADE AND AN ADDITIONAL SAMPLE WAS COLLECTED OF THE BROWNISH/BLACK TAR MATERIAL FROM TAB FLOOR UNDER TEE "A "TRAIN BY USING A CLEAN SPATULA TO SCOOP THE MATERIAL FrA THE FLOOR INTA A PRE-TARED SAMPLE CONTAINER PReVISE BY THE 222-S'LAB. EXTRA SAMPLE OF THE CRY STA U LINE MATERIAL FRom unDER

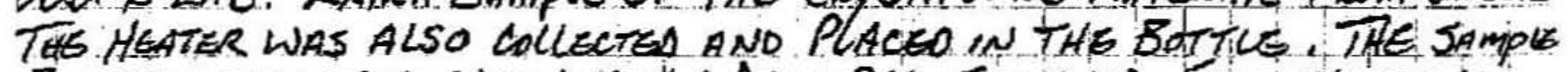
BOTTLE WAS WIPEO CLEAN WITH' A DAMP RAG, SURUEYSO FROM THE ZONB, SEALED WITH EVIDENCE TAPE, DOUBLE BAGGED AND PLACES IN A COLE. THE SAMPLE WAS SHIPPED TO THE 222-S LAB UN AN UN SITE ROUTINE RADIOACTIVE SHIPMENT RECORD, SITE-03- EXCEPTED, CAY
110."
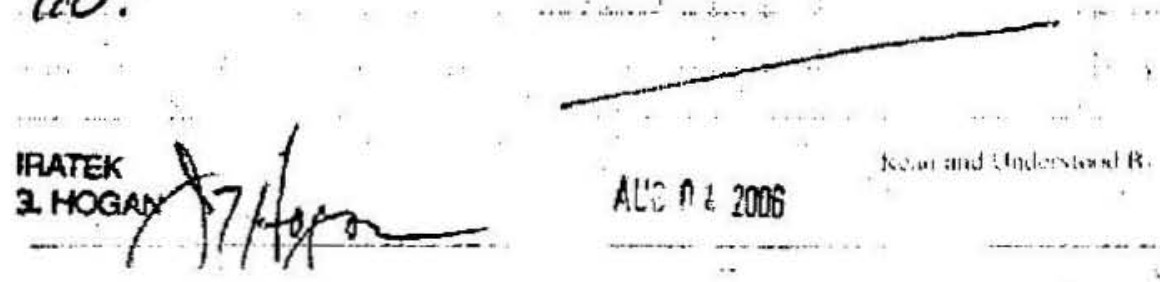

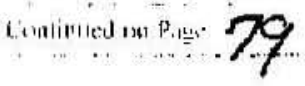

AL: ก 12006

A- 68 
Page 94 of 162 of DA04063678

$$
\text { RPP-RPT-31293, Rev. } 0
$$

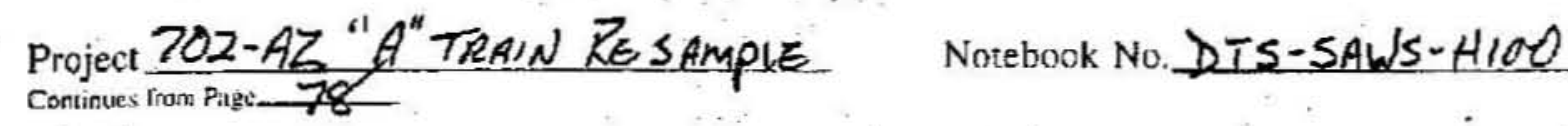

79

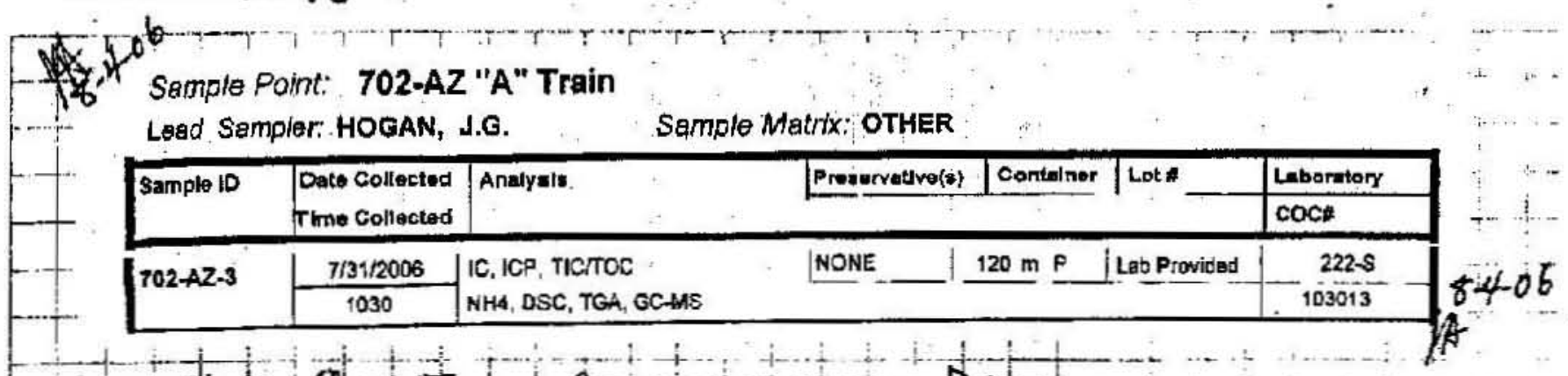

Note OWe form ATtacHED THIS PAGE

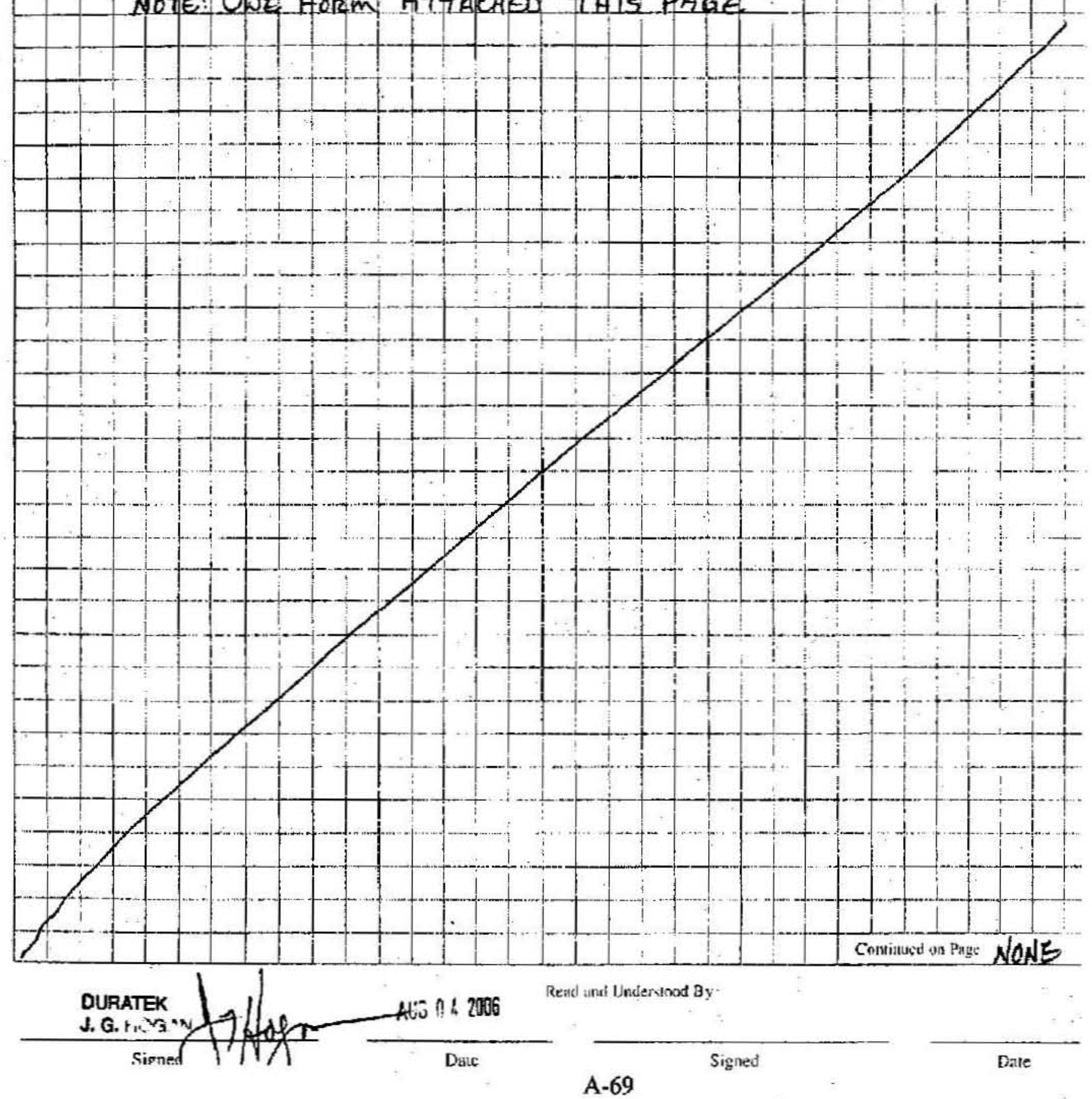




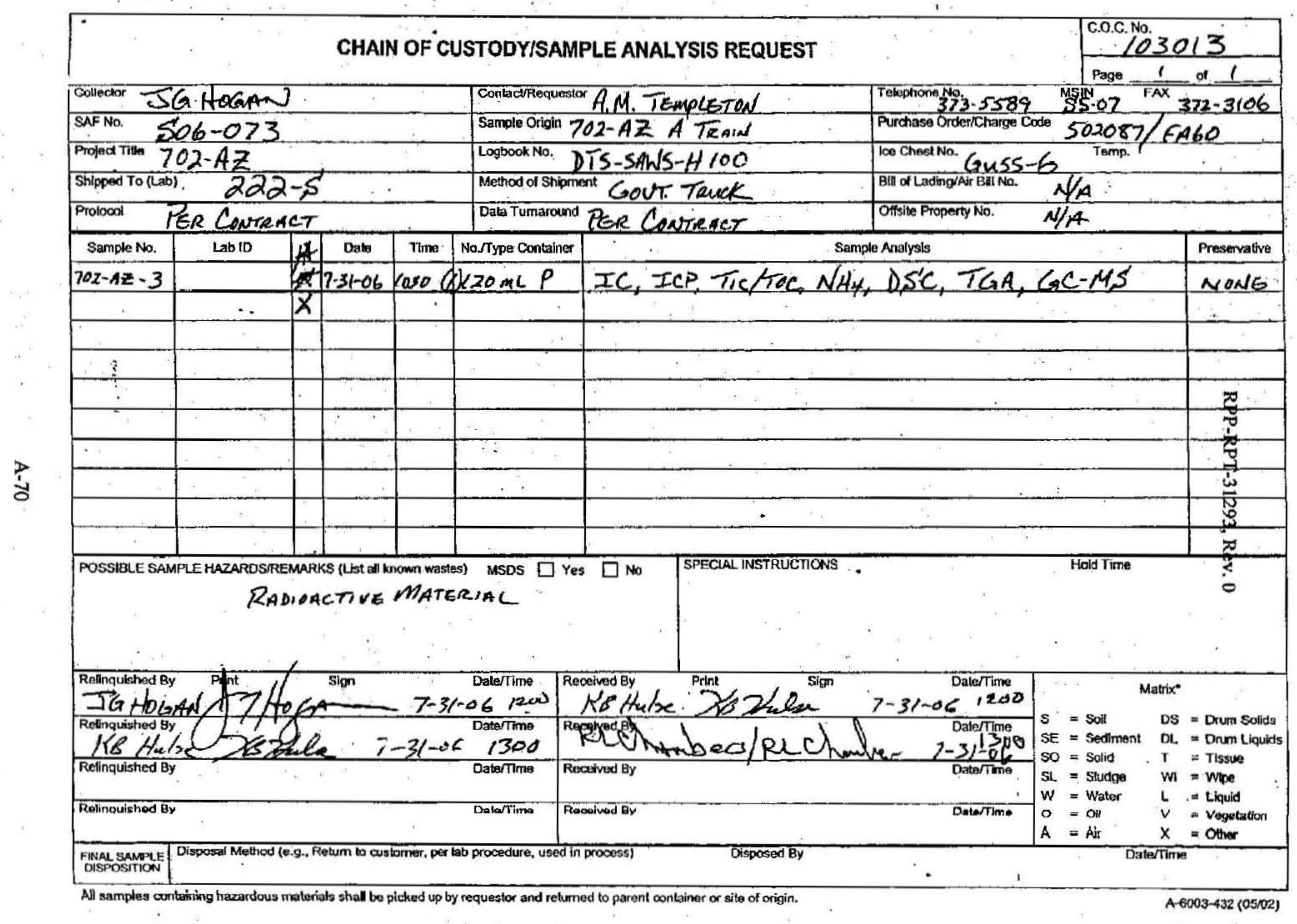


From: Jorgensen, David M

Sent: Tuesday, July 25, 2006 11:00 AM

To: $\quad$ Parnell, William L (Bill); Templeton, Andrew M; Gustavson, Robert D; Meldrom, Clarence A Jr; Hogan, James G; Chapman, Stephen R; Jorgensen, David M

Subject: RE: Actions for sampling 702AZ A-train WFO-WO-05-000646

Folks,

I just talked to Jim Hogan and he sald he could support it early next week so could we have Bill Pamell set it up for Monday to do the prejob and sample on the floor. ??

Jim said he has everything we need as far as both tools and charge code.

I will take $\mathrm{pkg}$ to Steve Chapman and it will be ready to go.

Dave Jorgensen

From: Parnell, William $L$ (Bill)

Sent: Tuesday, July 25, 2006 10:16 AM

To: Jorgensen, David M; Templeton, Andrew M; Gustavson, Robert D; Meldrom, Clarence A Jr; Hagan, James G; Chapman, Stephen R

Subject: RE: Actions for sampling 702AZ A-train WFO-WO-05-000646

This package is on the schedule for next week. With the attention this system is getting, we need to hold the schedule.

From: Jorgensen, David $M$

Sent: Tuesday, July 25, 2006 10:01 AM

To: Templeton, Andrew M; Jorgensen, David M; Gustavson, Robert D; Meldrom, Clarence A Jr; Hogan, James G; Chapman, Stephen R; Parnell, William L (Bill)

Subject: Actions for sampling 702AZ A-train WFO-WO-05-000646

Folks we need to coliect at least 10 grams more material from the floor under the filter housing

Here are the actions and questions as I see it:

Jim Hogan - 373-7063 308-0141

Do you still have what you need to come take this sample for work charges ect.? If issues call Al Meldrom or Andrew Templeton. Able to ace in still?

Can we have you supply the container and scooper this time that you would nomally use. These are not microbiological samples this time so what ever clean items you would normally use should work fine..

Al Meldrom - 373-2542 438-9666

If $\mathrm{Jim}$ Hogan is needing something different than last time you will need to supply this, - \$ contract ect.

Steve Chapman - 373-3770 308-7806

You will need to hold a Prejob and set up to do this collection again. I would hold up until we make sure Jim Hogan is ok with coming and has the collection tools needed. If Jim says he is ready then lets go get it done.

Please make sure we do not do this sample Aug B-10 as Andrew Templeton wants to be with the sampler when it is done.

Andrew Templeton - 373-5589 438-0701

is getting the sample plan revised to match the new testing requirements...this wili not hold up us getting the material sampled and perhaps tested.

Dave Jorgensen $-373-6065$ Planner - I will be on vacation July $26 \& 27$ th

This is East tank farms highest prionity according to their priority list the other day so we need to move on it and make it happen. 
Re: FW: Actions for sampling 702AZ A-train WFO-WO-05-000646

Hagan, James G

RPP-RPT-31293, Rev. 0

From: Jorgensen, David $M$

Sent: Tuesday, July 25, 2006 12:49 PM

To: Reining, Timothy L; Hogan, James G; Jorgensen, David M; Parnell, Wiliam L (Bill); Chapman, Stephen R; Meldrom, Clarence A Jri, Templeton, Andrew M

Subject: RE: FW: Actions for sampling 702AZ A-train WFO-WO-05-000646

Tim,

This is East Tank farms top priority job. We have large cast of folks that support this job.

When I talked to Jim Hogan about and hour ago he said he had nothing scheduled for that day so it should be no problem that day.

We really need to stay with Monday July 31 7:45 AM M0511

This has extremely high visibility right now including the state, Environmental, DOE and Roy Shepens.

Dave Jorgensen 373-6065

From: Timothy Relning [mallto:TLRENING@energysolutions.com]

Sent: Tuesday, July 25, 2006 11:49 AM

To: Jorgensen, David $M$

Subject: Re: FW: Actions for sampling 702AZ A-train WFO-WO-05-000646

David,

If nocessary, can this work be performed on the back shift? I have severa! jobs pending for NCO support and not enough staff to go around. We are in the process with Fluor IR in hiring two additional NCO's and three temporary, Thanks.

TL Reining

Supervisor/Planner Scheduler

Duratek Federal Services Inc Groundwater Sampling Services

376-0415 or $438-7728$

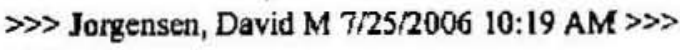

FYl,

Hopefully Jim is around and not on 5 week vacation :-)

Dave Jorgensen 373-6065

From: Parnell, William L (Bili)

Sent: Tuesday, July 25, 2006 10:16 AM

To: Jorgensen, David M; Templeton, Andrew M; Gustavson, Robert D; Meldrom,

Clarence A Jr; Hogan, James G; Chapman, Stephen R

Subject: RE: Actions for sampling 702AZ A-train WFO-WO-05-000646

This package is on the schedule for next week. With the attention this system

$7 / 26 / 2006$ 
Re: FW: Actions for sampling 702AZ A-train WFO-WO-05-000646

RPP-RPT-31293, Rev. 0

From: Jorgensen, David M

Sent: Tuesday, July 25, 2006 10:01 AM

To: Templeton, Andrew M; Jorgensen, David M; Gustavson, Robert D; Meldrom, Clarence A Jr; Hogan, James G; Chapman, Stephen R; Parnell, Williaim L (Bill)

Subject: Actions for sampling 702AZ A-train WFO-WO-05-000646

Folks we need to collect at least 10 grams more material from the floor under the filter housing.

Here are the actions and questions as I see it:

Jim Hogan - 373-7063 308-0141

Do you still have what you need to come take this sample for work charges ect.? If issues call A1 Meldrom or Andrew Templeton.

Able to ace in still?

Can we have you supply the container and scooper this time that you would normally use. These are not microbiological samples this time so what ever clean items you would normally use should work fine..

Al Meldrom - 373-2542 438-9666

If Jim Hogan is needing something different than last time you will need to supply this. - $\$$ contract ect.

\section{Steve Chapman - 373-3770 308-7806}

You will need to hold a Prejob and set up to do this collection again. I would hold up until we make sure Jim Hogan is ok with coming and has the collection tools needed. If Jim says he is ready then lets go get it done.

Please make sure we do not do this sample Aug 8-10 as Andrew Templeton wants to be with the sampler when it is done.

Andrew Templeton - 373-5589 438-0701 is getting the sample plan revised to match the new testing requirements...this will not hold up 15 getting the material sampled and perhaps tested.

Dave Jorgensen -373-6065 Pianner - I will be on vacation July $26 \& 27$ th

This is East tank farms highest priority according to their priority list the other day so we need to move on it and make it happen.

\section{Thanks}

Dave Jorgensen 
Page 99 of 162 of DA04063678

RPP-RPT-31293, Rev. 0

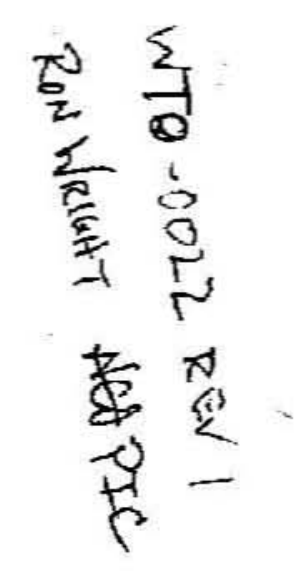


RPP-RPT-31293, Rev. 0

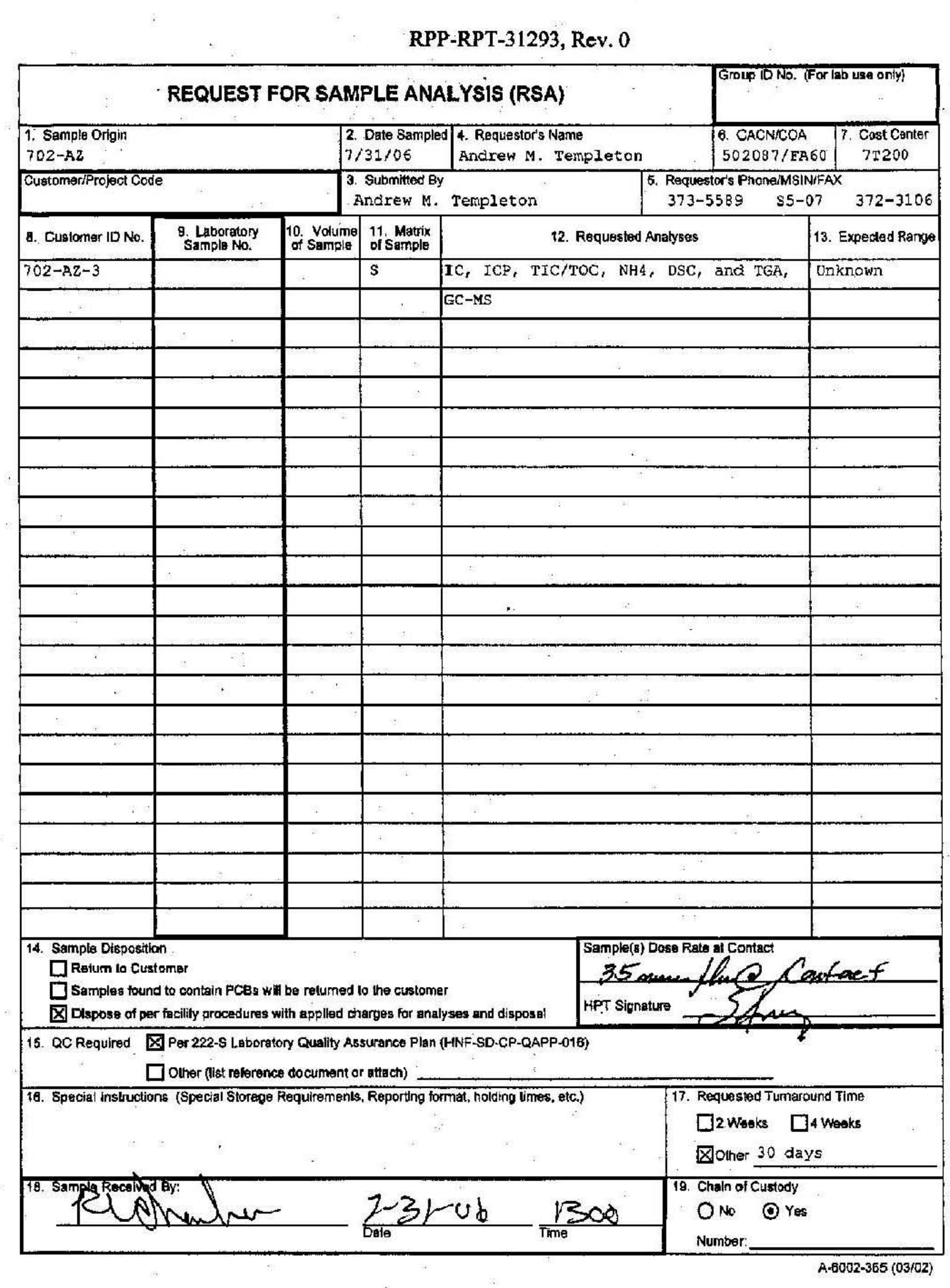

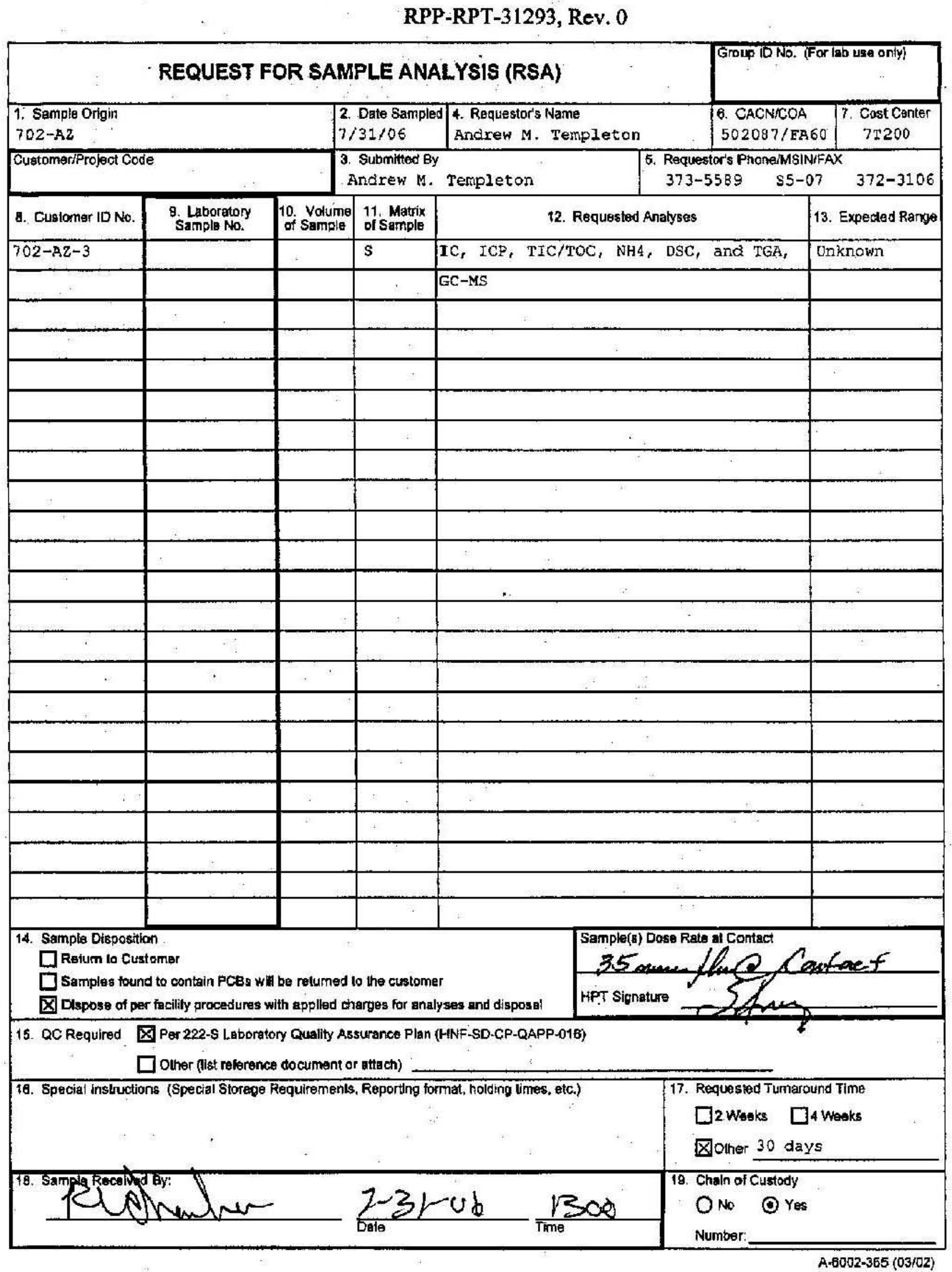




\section{GENERATOR KNOWLEDGE INFORMATON}

1. Chain of Custody Number N/A CACN/COA 502087 Customer Identification Number $702-A Z \cdot 3$

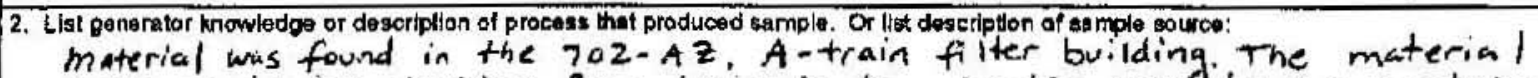

appears to be leakling from beneath the henter pridf to the airstream

MSDS Avallabd? No $O$ Yes Mantord MSDS Nio.

3. List all wasto codes and constifuents associated with the wasto of modio that was asmpled, ra gardiose of CERCLA status.

a) Does the sample contain any of the following listed waste sades?

By oheaking "unknown" the customer understands that no knowledge is avalloble following a cereful searah. List Federal Waste Code(s):

List Constituent(s):
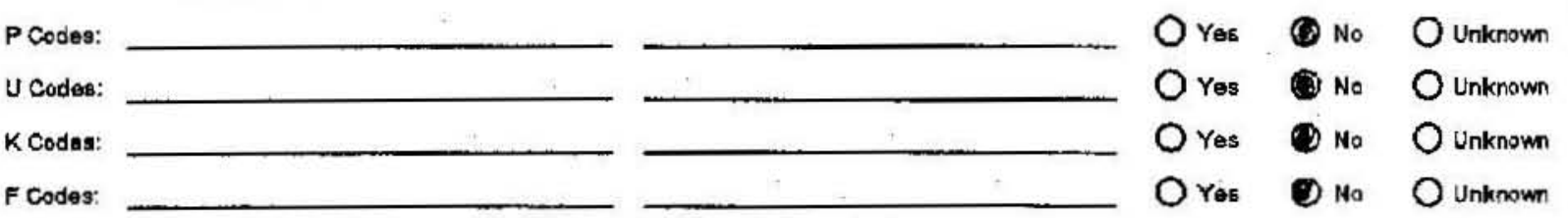

b) List applicable characteristic waste codes, lash point, $\mathrm{pH}$, constituents, and concenirations es approprials.
0001: $\square \mathrm{FP}<100^{\circ} \mathrm{F}$
$\square \mathrm{FP} \geq 100<140^{\circ} \mathrm{F}$
$\square$ DOT Oxidizer
D002: $\square \mathrm{pH} \leq 2$
$\square \mathrm{pH} \geq 12.5$
$\square$ solid Corrostive (w3C2)
O Yes $O$ No
Y Yes $\mathrm{O}$ No
Unknown
Do03: $\square$ Cyanide $\square$ sulfice $\square$ water Reactive
$\square$ Other
ti.e. peroxide former,
explosive, al reactive)
$O$ Yos $O$ no
Unknown
0004-D043 (identify applicable waste codes and concentrations):
0 Yes
P No
Unknown
Unknown

c) If characteriatic, list any knowm underlying hazardous constiuents (UMCs) reasonably expected to present, and tha ir concentrations that may be present above the LDR treatrnent standard (40 CFR 268.48):

d) List any known Land Disposal Restrictions (LDR) subcategories, if applcable (40 CFR 266.40):

•) List any appileabla Washington State dangerous waste codes: (not required if federally reguated)
WTO1:
Y Yes
No
(2) Unknown
WTO2:
Ores. $O$ no
U. Unknown
wool: $O$ Yos No $O$ unknown

List constituents and concontratlons:

("State mixturo rule for ianitability)

WP01: $O$ Yes No $Q$ unknown wPo2: OYes No $O$ unknowm wro3: O Yos * No O unknown fons:- OYes O no O Unknowm

4. Is this matorial TSCA regulated for PCBe? $O$ Yos No $O$ uniknown $O$ Analysis Requested

Llst concentration it applicable:

If yea, what is the source of the PCBs? (see TSCA PCB Henford Sitt User Guide, DOERL-2001-50)

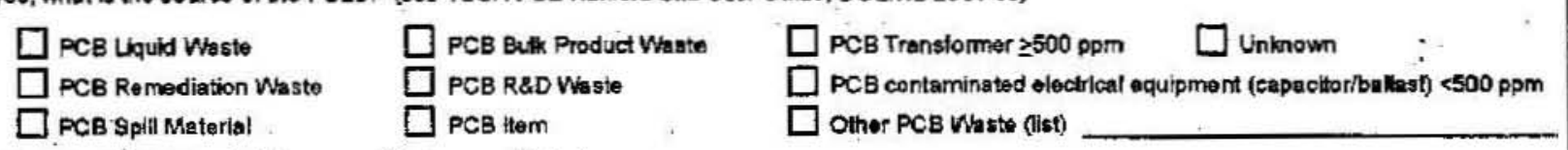

5. Is this material TRU? $O$ Yas No Ouniknown

6. ACCURACY OF INFORMATION

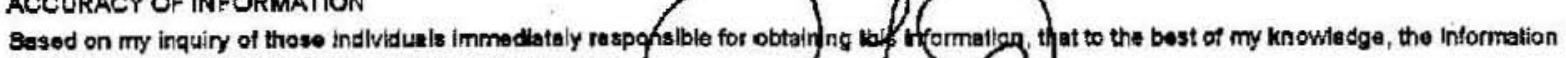
entered in this document is true, accurate, end complete Print \& Sign Anorow un. Temputern 
RPP-RPT-31293, Rev. 0

\section{APPENDIX B}

\section{LABORATORY SAMPLE BREAKDOWN DIAGRAMS}




\section{AZ TRAIN}

Due Date: 06/23/06

Primary Analyses

Location: 2B

Group 20060609

Special Sample(Total) Special Sample(Total)
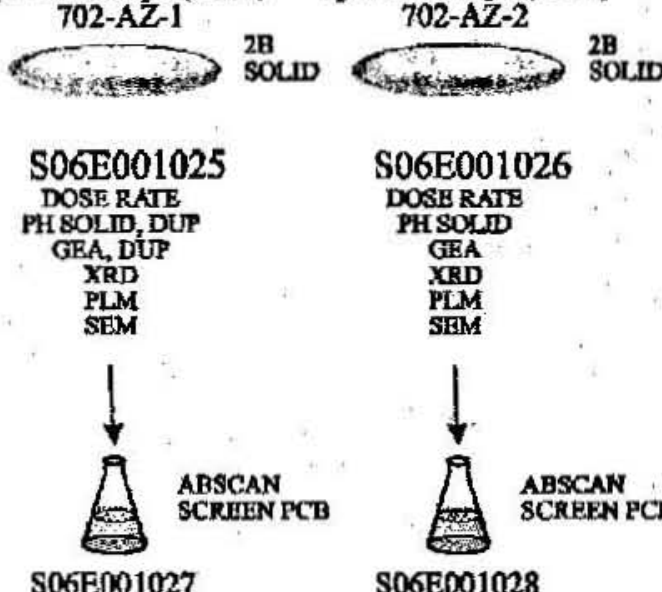

S06E001026

DOSE RATE

GEA

XRD
PLM
SEMM

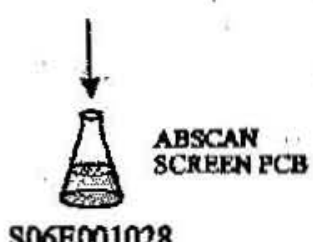

S06E001028

Special Sample(Total)

$$
\begin{aligned}
& \text { AZ-301 } \\
& \text { is }
\end{aligned}
$$

\section{S06E001029}

DUSE RATB

PH SOLID DOSERATB, PH SOLD, XRD AND GEA

GBA Thate ddted the to lack of enompla.

XRD That dededed die

SEM

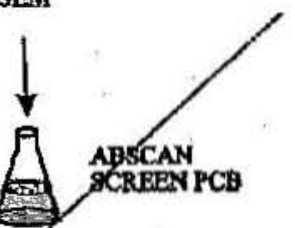

S06E061030

Test deleted due to lack of sample.

Special Sample(Total) Special Sample(Total) Special Sample(Total) Special Sample(Total) $702-A Z-2 A$ 702-AZ-2B

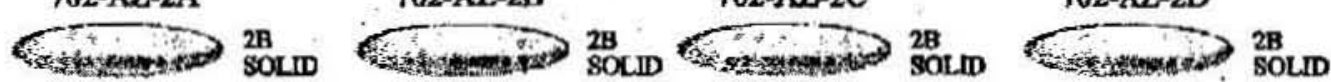

S06E001013 S06E001014

S06E001015

S06E001016 SAMPLE RECBIVBD SAMPLB RBCEIVED SAMPLERBCETVD SAMPLB RECEIVTD

Special Sample(Total) Special Sample(Total) Special Sample(Total) Special Sample(Total) 702-AZ-2E 702-AZ-2F 702-AZ-TSA-BLK 702-AZ-SAB-BLK

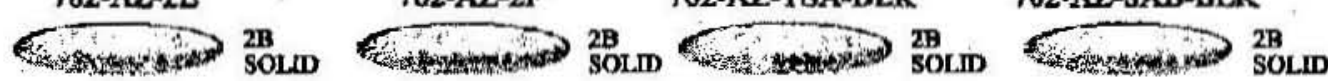
$\begin{array}{llrr}\text { S06E001017 } & \text { S06E001018 } & \text { S06E001019 } & \text { S06E001020 }\end{array}$ SAMPLE RECEIVED SAMPLE RECEIVED SAMPLE RECEIVED SAMPLERECETVED 702-AZ-TSA-FBLK 702-AZ-SAB-FBLK 702-AZ-TSA-TRPBLK 702-AZ-SAB-TRPBLK

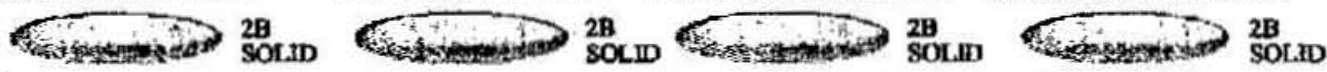
S06E001021 SAMPLE RECEIVEO S06E001022 SAMPLE RECEIVED
SO6E001023 SAMPLE RECHIVID
S06E001024 SAMPLE RECEIVED 


\section{AZ TRAIN}

Due Date: 08/29/06

Secondary Analyses

Location: 2B

Group 20060609

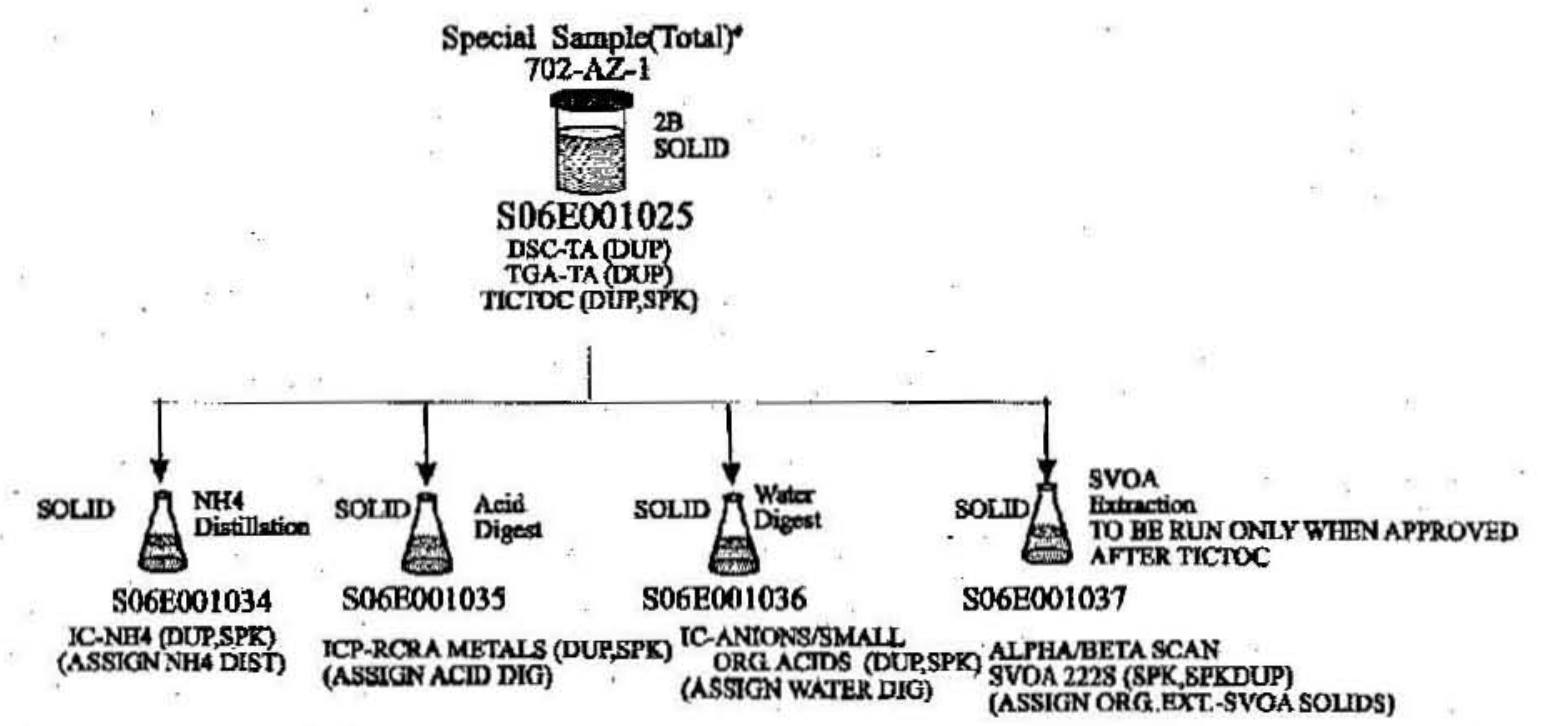

Special Sample(Total)

CTOC (DUP,SPA)
Special Sample(Total)

Blend of 702-AZ-2 \& 702-AZ-3

$\Rightarrow$ 2B

S06E001042

DSC-TA (DUP)

TGA-TA (DUP)

TICTOC

XEM

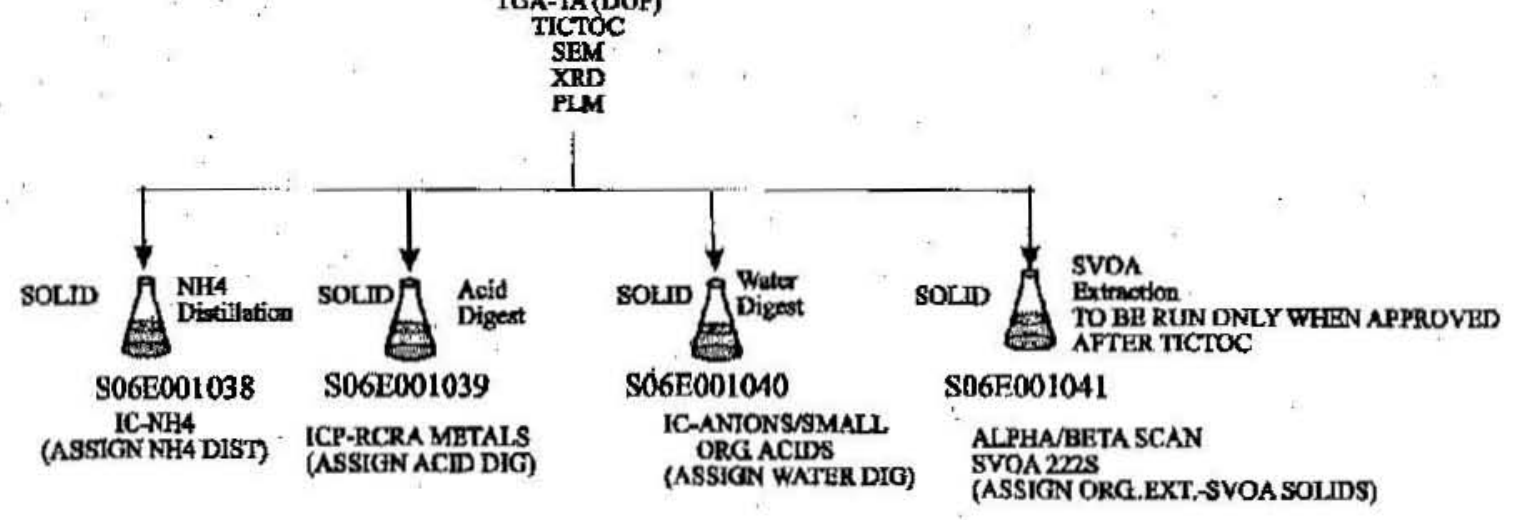


702AZ TRAIN

Due Date: 09/06/06

Secondary Analyses Additional

Location: 2B

Group 20060609

Special Sanmple (Total)

NH4NO3

2B. $2 \mathrm{~B}$

S06E001043

DSC-TA

\author{
Special Sample (Total) \\ NH4NO3-NACL

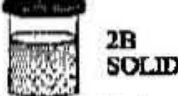 \\ S06E001044 \\ DSC-TA
}

No DUP AND SPK on these SAMPLES 
702AZ TRAIN

Due Date: 10/05/06

Additional Samples

Location: 2B

Group 20060609

Special Sample(Total)

702-AZ-1

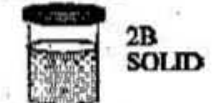

S06E001025

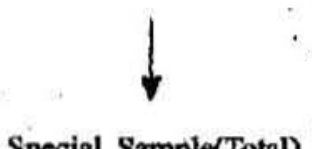

Special Sample(Total)

702-AZ-1

SOLID

SO6E001045 DSC-TA
Special Sample(Total)

Blend of 702-AZ-2 \& 702-AZ-3

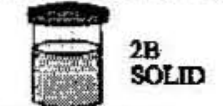

S06E001042

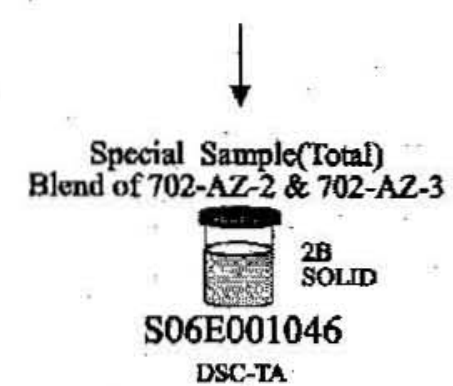

These samples and group are already logged in. This is additional work on these samples.

Special note - these samples are to be run using air as a cover gas. 
RPP-RPT-31293, Rev. 0

\section{APPENDIX C} MICROBIAL MEDIA AND PLATE COUNT RAW DATA

C-i 
Appendix C-1. Trypticase Soy Agar RODAC for General Surface Bacteria Counting (Catalogue \#221238, Becton Dickinson, Sparks, MD)

per liter:

Pancreatic Digest of Casein $\quad 15 \mathrm{~g}$

Papaic Digest of Soybean Meal $\quad 5 \mathrm{~g}$

Sodium Chloride $\quad 5 \mathrm{~g}$

Lecithin $\quad 0.7 \mathrm{~g}$

Polysorbate 80

Agar $15 \mathrm{~g}$

Appendix C-2. Sabouraud Dextrose Agar RODAC ${ }^{\oplus}$ for General Surface Fungi Counting (Catalogue \#221233, Becton Dickinson, Sparks, MD)

per liter:

Pancreatic Digest of Casein $\quad 5 \mathrm{~g}$

Peptic Digest of Animal Tissue : $\quad 5 \mathbf{g}$

Dextrose $\quad 40 \mathrm{~g}$

Agar $15 \mathrm{~g}$

$\mathrm{pH} \sim 5.6$

Appendix C-3. Phosphate-Buffered-Saline (PBS)

per liter

$\mathrm{Na}_{2} \mathrm{HPO}_{4} .7 \mathrm{H}_{2} \mathrm{O} \quad 2.22 \mathrm{~g}$

$\mathrm{NaH}_{2} \mathrm{PO}_{4} \cdot \mathrm{H}_{2} \mathrm{O} \quad 0.223 \mathrm{~g}$

$\mathrm{NaCl} \quad 8.5 \mathrm{~g}$

$\mathrm{pH}$ to 7.0

Appendix C-4. Trypticase Soy Agar for General Bacteria Plate Count

(Catalogue \# 0369-17, Becton Dickinson, Sparks, MD)

per liter:

Bacto Tryptone $\quad 15 \mathrm{~g}$

Bacto Soytone $\quad 5 \mathrm{~g}$

Sodium Chloride $5 \mathrm{~g}$

Bacto Agar $15 \mathrm{~g}$

Final $\mathrm{pH} 7.3 \pm 0.2$ at $25^{\circ} \mathrm{C}$

Appendix C-5. Sabouraud Dextrose Agar for General Fungi Plate Count

(Difco Catalogue \# 0109-15, Becton Dickinson, Sparks, MD)

per liter:

Bacto Neopeptone $\quad 10 \mathrm{~g}$

Bacto Dextrose $\quad 40 \mathrm{~g}$

Bacto Agar $15 \mathrm{~g}$

Final $\mathrm{pH} 5.6 \pm 0.2$ at $25^{\circ} \mathrm{C}$ 


\section{Appendix C-6. Microblal Enumeration for S06E001025 and S06E001026}

\begin{tabular}{|c|c|c|c|c|c|c|c|}
\hline \multicolumn{3}{|c|}{ Microbial Plate Counts } & & & & & \\
\hline \multicolumn{8}{|c|}{ The plates were inoculated on June 28,2006 , put in a closed container, and read on July 3, 2006.} \\
\hline \multicolumn{5}{|c|}{ The samples were suspended in $2 . \mathrm{mL}$ of sterile PBS } & & & \\
\hline \multicolumn{3}{|c|}{ Sample number } & & & & & \\
\hline \multicolumn{3}{|c|}{$\begin{array}{l}\text { S06E001925 (brown erystal } \\
\text { material) }\end{array}$} & & & & . & \\
\hline \multirow{2}{*}{ Agar } & \multirow{2}{*}{ Dilution } & \multicolumn{3}{|c|}{ colony-forming-units, CFU } & \multirow{2}{*}{$\begin{array}{l}\text { Average } \\
\text { (CFU) }\end{array}$} & \multirow{2}{*}{$\begin{array}{l}\text { Sample } \\
\text { Weight } \\
\text { (gram) }\end{array}$} & \multirow{2}{*}{ CFU/gram" } \\
\hline & & rep 1 & rep 2 & rep 3 & & & \\
\hline \multirow[t]{3}{*}{ TSA } & $10^{\mathrm{k}}$ & 120 & 104 & Contaminated $^{c}$ & 112 & 0.145 & $1.5 \mathrm{E}+03$ \\
\hline & 100 & 1 & 1 & & & & \\
\hline & 1000 & $\mathrm{NG}^{\mathrm{d}}$ & NG & & & & \\
\hline \multirow[t]{3}{*}{$\mathrm{SAB}$} & 10 & NG & NG & & 0 & 0.145 & bd $^{\circ}$ \\
\hline & 100 & NG & NG & & & & \\
\hline & 1000 & NG & NG & & & & \\
\hline & & & & & & & \\
\hline \multicolumn{2}{|c|}{$\begin{array}{l}\text { S065001026 (floor } \\
\text { material) }\end{array}$} & & . & & & & . \\
\hline \multirow[t]{3}{*}{ TSA } & 10 & 65 & 78 & Not Counted ${ }^{p}$ & 72 & 0.132 & $1.1 \mathrm{E}+03$ \\
\hline & 100. & NG & NG & 2. & & & \\
\hline & 1000 & NG & NG & & & & \\
\hline \multirow[t]{3}{*}{$\mathrm{SAB}$} & 10 & 39 & 1 & & 39 & 0.132 & $5.9 \mathrm{E}+02$ \\
\hline & 100 & NG & NG & & & & \\
\hline & 1000 & $N G$ & NG & & & & \\
\hline & & & & & & & \\
\hline & & & & & & & \\
\hline \multicolumn{7}{|c|}{ (a): CFU/gm = (Average CFU/plate) $\times$ (plate/1mL) $\times$ (2 mL/mass in gram) } & \\
\hline \multicolumn{8}{|c|}{ (b): $1 \mathrm{~mL}$ of initial dilution (weighed out mass diluted in $2 \mathrm{ml}$ PBS) } \\
\hline \multicolumn{8}{|c|}{$\begin{array}{l}\text { (c): The third replicate (rep 3) from the sample was overgrown with bacterial colonies (Proteus sp.) and not } \\
\text { countable, likely caused by airbome contamination. Statistically significant counts range from } 30 \text { to } 300 \text { CFUs. }\end{array}$} \\
\hline \multicolumn{8}{|c|}{ (d) NG $=$ No growth } \\
\hline \multicolumn{8}{|c|}{ (e) below detecting timit of 4.1E+00 CFU/gram } \\
\hline \multicolumn{8}{|c|}{$\begin{array}{l}\text { (f) Replication } 3 \text { was overpopulated (not contaminated) when first prepared and unable to distinguish individual } \\
\text { colony foci to allow counting, possibly caused by nonhomogeneity of the sample preparation. The rep } 3 \text { of the } \\
\text { sample preparation may have contained a microscopic particle on which a plethora of individual microbial cells } \\
\text { were attached such that when the spread plate was created the microbial cells were spread over the surface of the } \\
\text { agar. Excessive colony foci growth was not observable when the plate was read on three different occasions. }\end{array}$} \\
\hline
\end{tabular}




\section{RPP-RPT-31293, Rev. 0}

\section{Appendix C-7. Soil Sample from 300 Area as comparison for enumeration of sample microbe counts.}

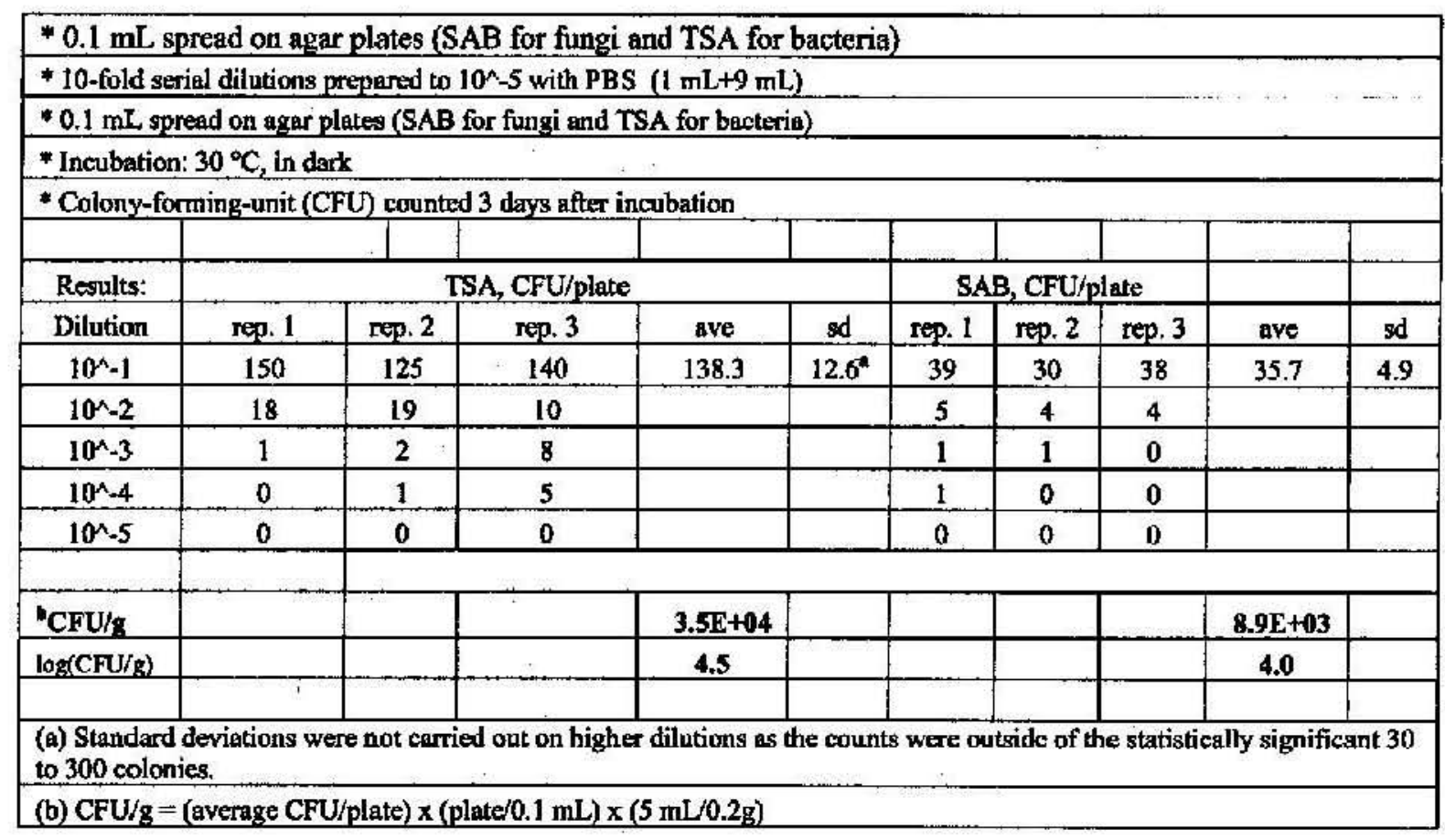


RPP-RPT-31293, Rev. 0

APPENDIX D

ANALYTICAL RESULTS

D-i 
DSR - 20060609

702AZ TRAIN

\section{Sample Group: 20060609}

Core Number: 20060609

Sample Portion: Special Sample (Total)

Customer Sample ID: 702-AZ-1

\begin{tabular}{|c|c|c|c|c|c|c|c|c|c|c|c|c|c|c|}
\hline \multirow{2}{*}{ Samples $R$} & \multirow[b]{2}{*}{ All } & \multirow[b]{2}{*}{ Analyce } & \multirow[b]{2}{*}{ Unit } & \multicolumn{2}{|c|}{ Control Limits } & \multirow[b]{2}{*}{ Standard $x$} & \multirow[b]{2}{*}{ Blank. } & \multirow[b]{2}{*}{ Resultef } & \multirow{2}{*}{ Dupticato } & \multirow[b]{2}{*}{ Average } & \multirow[b]{2}{*}{ RPD $\%$} & \multirow[b]{2}{*}{ Spk Rec \% } & \multirow[b]{2}{*}{ Det Limlef } & \multirow[b]{2}{*}{ Qual Flags } \\
\hline & & & & Lower & Upper & & & & & & & & & \\
\hline SO6E001025 & & Actinium-228 & uCilg & None & None & na & $<7.74 \mathrm{E}-05$ & $<8.95 E-05$ & $\mathrm{n} / \mathrm{s}$ & $\mathrm{n} / \mathrm{a}$ & n/a & $\mathrm{n} / \mathrm{a}$ & 8.95E-05 & $\bar{U}$ \\
\hline S06E001025 & & Aluminum-28 & $\mathrm{uCi} / \mathrm{g}$ & None & None & n/a & $<8.10 \mathrm{E}-04$ & $<8.04 E-04$ & $\mathrm{n} / \mathrm{a}$ & $\mathrm{n} / \mathrm{a}$ & $\mathrm{n} / \mathrm{a}$ & n/a & $8.04 E-04 / L$ & $\mathbf{U}$ \\
\hline SO6E.001025 & & Americium-241 & JuCig & None & None & $\mathrm{n} / \mathrm{a}$ & $<1.95 E-05$ & $<1.54 \mathrm{E}-04$ & $n / a$ & $n / a$ & $\mathrm{n} / \mathrm{a}$ & $n / a$ & $1.54 \mathrm{E} \cdot 04$ & $\mathbf{U}$ \\
\hline SO6E001025 & & Americium-243 & uCig & None & None & $n \in$ & $<1.32 \mathrm{E}-05$ & $<8.25 E-05$ & n/a & $n / a$ & nat & $\mathrm{n} / \mathrm{a}$ & $8.26 \mathrm{E}-05 \mathrm{~L}$ & $U$ \\
\hline SO6E001025 & & Antimony-124 & uCV/g & None & None & $n / 2$ & $<1.55 E-05$ & $\angle 1.29 E-04$ & $n / a$ & $\pi / a$ & $\mathrm{n} / \mathrm{a}$ & $\mathrm{n} / \mathrm{a}$ & $1.29 \mathrm{E}-04 \mathrm{~L}$ & 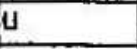 \\
\hline $506 E 001025$ & & Antimany-125 & $\mathrm{uCV}_{\theta}$ & None & None & n/A & $\angle 4.05 E-05$ & $<7.59 \mathrm{E}-04$ & $\mathrm{n} / \mathrm{a}$ & $\pi / \mathrm{a}$ & $\mathrm{n} / \mathrm{a}$ & $\mathrm{n} / \mathrm{a}$ & $7.59 \mathrm{E} \cdot 04 \mathrm{U}$ & $\mathbf{U}$ \\
\hline S06E001025 & & Antimany-126 & uCV $V_{g}$ & None & None & $\mathrm{n} / \mathrm{a}$ & $<1.74 E-05$ & $<4.53 E-05$ & $\mathrm{n} / \mathrm{a}$ & $\pi /$ a & $n / a$ & $\mathrm{n} / \mathrm{a}$ & 4.53E-05 & $\underline{u}$ \\
\hline SO6E001025 & & Argon-41 & uCvg & None & None & $n / a$ & $<3.45 E-05$ & $<3.62 E-05$ & $\mathrm{n} / \mathrm{a}$ & $n / \mathrm{B}$ & $n / a$ & $\mathrm{n} / \mathrm{a}$ & $3.62 E-056$ & U \\
\hline S06E001025 & & Barium-133 & $4 \mathrm{CV} / \mathrm{g}$ & None & None & n/a & $<1.72 E-05$ & $<2.85 E-04$ & $\mathrm{n} / \mathrm{a}$ & n/目 & $\mathrm{na}$ & n/a & 2.85E-04/ & $\mathbf{U}$ \\
\hline S06E001025 & & Barium-140 & JuCVg & None & None & $n / a$ & $<5.60 \mathrm{E}-05$ & $\angle 6.60 E-04$ & $n / a$ & $\mathrm{n} / \mathrm{a}$ & $n / a$ & n/a & $6.60 \mathrm{E}-04 \mathrm{j}$ & $J$ \\
\hline SO6E001025 & & Beryllium-7 & JuCivg & None & None & $\mathrm{n} / \mathrm{a}$ & $<1.03 E-04$ & $\angle 2.30 E-03$ & $\mathrm{n} / \mathrm{a}$ & n/a & $\pi / 8$ & $\mathrm{n} / \mathrm{a}$ & $2.30 \mathrm{E}-03 \mathrm{C}$ & $\bar{U}$ \\
\hline S06E001025 & & Bismuth-207 & uCig & Nane & None & $\mathrm{n} / \mathrm{a}$ & $<2.51 E-0.5$ & $<2.83 E-05$ & n/a & $n / a$ & n/a & $n / a$ & $2.83 \mathrm{E}-0.5 \mathrm{C}$ & $\mathrm{U}$ \\
\hline S08E001025 & & Bismuth-212 & $\mu \mathrm{Cug}$ & None & None & $\mathrm{n} / \mathrm{a}$ & $<1.46 \mathrm{E}-04$ & $<2.65 \mathrm{E}-04$ & n/a & n/a & n'a & nia & 2.65E-04 & $\bar{U}$ \\
\hline SOSE001025 & & Bismuth-214 & uCi/g & Nane & None & $n / a$ & $<3.73 E-05$ & $<2.69 \mathrm{E}-04$ & $n / a$ & $n / a$ & n/a & $\mathrm{n} / \mathrm{a}$ & $2.69 \mathrm{E}-04 \mathrm{C}$ & $U$ \\
\hline S06E001025 & & Cadmium-109 & $\mu \mathrm{C} v g$ & None & None & $\mathrm{n} / \mathrm{a}$ & $<1.43 E-04$ & $<1.43 \mathrm{E}-0 \mathrm{j}$ & n/a & $n / a$ & $n / a$ & $n / a$ & $1.43 \mathrm{E}-03 \mathrm{~V}$ & $\mathbf{U}$ \\
\hline S06E001025 & & Cerium-139 & uCikg & Nane & None & $n / 3$ & $<9.01 E-06$ & $<1.09 E-04$ & $n / a$ & $\mathrm{n} / \mathrm{a}$ & $n / a$ & $n / a$ & $1.09 \mathrm{E}-04 \mathrm{C}$ & $U$ \\
\hline S06E001025 & & Cerium-141 & uCing & None & None & $\mathrm{na}$ & $<1.23 E-05$ & $<1.39 E-04$ & $n / a$ & $\mathrm{na} / \mathrm{a}$ & $\mathrm{n} / \mathrm{a}$ & $n / a$ & $1.39 \mathrm{E}-04 \mathrm{C}$ & $u$ \\
\hline SO6E001025 & & Cerium-144 & uCVIg & None & None & $\mathrm{n} / \mathrm{a}$ & $<5.14 \mathrm{E}-05$ & $<5.86 \mathrm{E}-04$ & $\mathrm{n} / \mathrm{a}$ & $\mathrm{n} / \mathrm{a}$ & na & $\mathrm{n} / \mathrm{a}$ & $5.86 E-04$ & $U$ \\
\hline SO6E001025 & & Ceriurn/Prasecodymium-144 & uCing & None & None & $n / a$ & $<1.03 E-04$ & $<1.17 E-03$ & $n / a$ & $n / a$ & nia & $\mathrm{n} / \mathrm{a}$ & 1,17E-03L & $\mathrm{U}$ \\
\hline S06E001025 & & Cesium-134 & $u C / g$ & None & None & $\mathrm{n} / \mathrm{a}$ & $<1.63 E-05$ & $<1.29 E-04$ & na & $\mathrm{n} / \mathrm{a}$ & $n / a$ & $n / a$ & $1.29 E-04 \mathrm{~L}$ & $\mathbf{u}$ \\
\hline S06E001025 & & Cesium-136 & $u C V / g$ & None & None & $\mathrm{n} / \mathrm{a}$ & $<1.73 \mathrm{E}-05$ & $<2.73 E-05$ & $\mathrm{n} / \mathrm{a}$ & $n / a$ & naa & $n / a$ & $2.73 E-051$ & $U$ \\
\hline S06E001025 & & Cesium-137 & uCilg & None & None & 99.1 & <1.81E-05 & 0.338 & $\mathrm{n} / \mathrm{a}$ & $n / a$ & na & $\mathrm{n} / \mathrm{a}$ & $2.43 E-0.4$ & \\
\hline SO6E001025 & & Cesium-138 & uCing & None & None. & $\mathrm{n} / \mathrm{a}$ & $<8.50 E-05$ & $<B .84 \mathrm{E}-05$ & $\mathrm{n} / \mathrm{a}$ & $\mathrm{n} / \mathrm{a}$ & $n / a$ & N/B & $8.84 E-05$ & $\underline{u}$ \\
\hline S06E001025 & & Chlorine-38 & $\mathrm{uCV} / \mathrm{g}$ & None & None & $\mathrm{n} / \mathrm{a}$ & $<138 E-04$ & $<1.53 \mathrm{E}-04$ & $n / a$ & $\mathrm{n} / \mathrm{a}$ & n/a & $\pi / a^{\prime}$ & $1.53 \mathrm{E}-0.4$ & U \\
\hline S06EC001025 & & Chromium 5t & uCl/g & None & None & $\mathrm{n} / \mathrm{a}$ & $<1.03 E-04$ & $<1,47 \mathrm{E}-03$ & $\mathrm{n} / \mathrm{a}$ & $\pi / a$ & $\mathrm{n} / \mathrm{a}$ & $\mathrm{n} / \mathrm{a}$ & 1.47E-03L & U \\
\hline S06E001025 & & Cobalt- 56 & uCi/g & None & None & $\mathrm{n} / \mathrm{a}$ & $<1.72 \mathrm{E}-05$ & $<2.53 E-05$ & $\mathrm{n} / \mathrm{a}$ & n/a & ת/a & na & $2.53 E-05$ & $\bar{U}$ \\
\hline SO6ECOD1025 & & Cobalt-57 & uCivg & None & None & $\mathrm{n} / \mathrm{a}$ & $<6.64 E-06$ & $<727 \mathrm{E}-05$ & $\mathrm{n} / \mathrm{a}$ & n/a & n/a & na & $7.27 \mathrm{E}-05$ & $U$ \\
\hline SOEEDO1025 & & Cobalt-58 & $\mathrm{uCi} / \mathrm{g}$ & None & None & N/目 & $<1.59 \mathrm{E}-05$ & $<2.75 \mathrm{E}-05$ & $\mathrm{Na}$ & $\mathrm{n} / \mathrm{a}$ & $n / a$ & $\mathrm{n} / \mathrm{a}$ & $2.75 E-05$ & $U$ \\
\hline
\end{tabular}

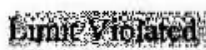


Sample Group: 20060609

Core Number: 20060609

Sample Portion: Special Sample (Total)

Customer Sample ID: 702-AZ-1

\begin{tabular}{|c|c|c|c|c|c|c|c|c|c|c|c|c|c|c|}
\hline \multirow[b]{2}{*}{ Sample: $\quad \mathbf{R}$} & \multirow[b]{2}{*}{ An: } & \multirow[b]{2}{*}{ Analyte } & \multirow[b]{2}{*}{ Unit } & \multicolumn{2}{|c|}{ Control Umiths } & \multirow[b]{2}{*}{ Standard $\%$} & \multirow[b]{2}{*}{ Btank } & \multirow[b]{2}{*}{ Resultef } & \multirow[b]{2}{*}{ Duplicate } & \multirow[b]{2}{*}{ Average } & \multirow[b]{2}{*}{ RPD \% } & \multirow[b]{2}{*}{ Spk Rec X } & \multirow[b]{2}{*}{ Det Limin } & \multirow[b]{2}{*}{ Qual Flags } \\
\hline & & & & Lower & Uppar & & & & & & & & & \\
\hline SO6EO01025 & & Cobelt-60 & uCigg & None & None & 102 & $<1.92 \mathrm{E}-05$ & $<2.29 E-05$ & n/a & na & $\mathrm{n} / \mathrm{A}$ & $n / a$ & $2.29 E-05$ & $\bar{U}$ \\
\hline SO6E001025 & & Copper-64 & uCing. & None & None & n/a & $\angle 4.48 \mathrm{E}-03$ & $<4.57 \mathrm{E}-03$ & $\mathrm{n} / \mathrm{a}$ & nfa & $n / 2$ & n/a & $4.57 \mathrm{E}-03 \mathrm{~L}$ & U \\
\hline SD6E001025 & & Copper-6B & uCing & None & None & $n / a$ & $\angle 4.55 \mathrm{E}-03$ & $\angle 5.14 E-03$ & $\mathrm{n} / \mathrm{a}$ & $\mathrm{n} / \mathrm{a}$ & $\mathrm{n} / \mathrm{a}$ & $\mathrm{n} / \mathrm{a}$ & 5.14E-03 & U \\
\hline S06E00t025 & & Europium-152 & uCivg & None & None & $n / \mathrm{a}$ & $<9.51 E-05$ & $<1.02 E-04$ & $n / a$ & $n / a$ & $\mathrm{n} / \mathrm{a}$ & $\mathrm{n} / \mathrm{a}$ & $1.02 \mathrm{E}-04 \mathrm{~L}$ & $\mathbf{U}$ \\
\hline SD6EO001025 & & Europium-154 & uCing & None & None & n'a & $<6.13 \mathrm{E}-05$ & $\triangle 6.79 \mathrm{E}-05$ & $\mathrm{~N} / \mathrm{a}$ & $\mathrm{n} / \mathrm{a}$ & $\mathrm{n} / \mathrm{a}$ & n/e & $6.79 \mathrm{E}-05 \mathrm{~L}$ & u \\
\hline SOSE001025 & & Europium-155 & uCivg & None & None & $\mathrm{n} / \mathrm{a}$ & $<235 E-05$ & $<2.57 E-04$ & $\mathrm{n} / \mathrm{a}$ & $n / a$ & $\mathrm{n} / \mathrm{a}$ & $\mathrm{Na}$ & $2.57 \mathrm{E}-04 \mathrm{t}$ & $\mathrm{u}$ \\
\hline $506 € 001025$ & & Gold-198 & ucivg & None & None & n/a & $<1.18 \mathrm{E}-05$ & $<2.21 \mathrm{E}-04$ & $n / a$ & $n / a$ & $\mathrm{n} / \mathrm{a}$ & $\mathrm{n} / \mathrm{a}$ & $2.21 \mathrm{E}-04$ & U \\
\hline SOBE001025 & & Hafnium-181 & uCigg & None & None & $\mathrm{n} / \mathrm{a}$ & $<1.47 E-05$ & $2.85 \mathrm{E}-04$ & $\mathrm{n} / \mathrm{a}$ & nat & $n / a$ & $\mathrm{n} / \mathrm{B}$ & 2.85E-04 & U \\
\hline SO6E001025 & & lodine-129 & uCivg & None & None & nia & $<1.33 \mathrm{E}-04$ & $<1.01 \mathrm{E}-03$ & $\mathrm{n} / \mathrm{a}$ & nfa & $\mathrm{n} / \mathrm{a}$ & $\mathrm{n} / \mathrm{a}$ & $1.01 \mathrm{E}-03$ & u \\
\hline S06E001025 & & lodine-131 & uCvg & None: & None & n/a & $<1.33 \mathrm{E}-05$ & $\leq 2.18 \mathrm{E}-04$ & $\mathrm{~N} / \mathrm{a}$ & $\mathrm{n} / \mathrm{a}$ & $n / a$ & $n / a$ & $2.18 \mathrm{E}-04$ & $\bar{u}$ \\
\hline SOBE001025 & & Iron-59 & uCivg & None & None & $n / a$ & $<3.86 \mathrm{E}-05$ & $\angle 4.00 E-05$ & $\mathrm{~N} / \mathrm{a}$ & nfa & $\mathrm{n} / \mathrm{a}$ & $\mathrm{n} / \mathrm{a}$ & 4.00E-05 & U \\
\hline SD6E001025 & & Krypton-85 & uCvg & None: & None & $\mathrm{n} / \mathrm{a}$ & $<4,20 \mathrm{E}-03$ & $<0.0439$ & $\mathrm{Na}$ & na & $n / 2$ & $\mathrm{n} / \mathrm{a}$ & 0.0439 & U \\
\hline SOBE001025 & & Lanthanum-140 & uCvg & None & None & $n / a)$ & $<2.32 \mathrm{E}-05$ & $<1.85 \mathrm{E}-06$ & $\mathrm{n} / \mathrm{a}$ & $n / a$ & $n / 8$ & $\mathrm{n} / \mathrm{a}$ & $1.95 \mathrm{E}-05$ & U \\
\hline SOBE001025 & & Lead-210 & uCvg & None: & None & $\mathrm{n} / \mathrm{a}$ & $<2.66 \mathrm{E}-04$ & $<1,66 E-03$ & $n / a$ & $n / a$ & $\mathrm{n} / \mathrm{a}$ & $\mathrm{n} / \mathrm{a}$ & $1.66 \mathrm{E}-03$ & $\mathbf{U}$ \\
\hline S06E001025 & & Lead-212 & uCVg & None & None & $n / a$ & $<2.09 \mathrm{E}-05$ & 2.63E-04 & $\mathrm{n} / \mathrm{a}$ & nat & $n / a$ & n/a & $2.83 \mathrm{E}-04 \mathrm{~L}$ & $\mathbf{U}$ \\
\hline S06E 001025 & & Lead-214 & uCvg & None & None & $\mathrm{na}$ & $<3.11 \mathrm{E}-05$ & $\angle 4.53 E-04$ & $n / a$ & $\mathrm{n} / \mathrm{a}$ & $n / a$ & Na & $4.53 \mathrm{E}-04 \mathrm{C}$ & $\mathbf{u}$ \\
\hline S06E001025 & & Manganese- 54 & uCivg & None & None & $\mathrm{n} / \mathrm{a}$ & $<1.75 \mathrm{E}-05$ & $\angle 2.58 E-05$ & $\mathrm{n} / \mathrm{a}$ & $\mathrm{n} / \mathrm{a}$ & $\pi / a$ & n/a & 2.58E-05t & $\mathrm{U}$ \\
\hline SO6E001025 & & Manganese- 56 & uCVg & None & None & $\mathrm{n} / \mathrm{a}$ & $<2.38 \mathrm{E}-05$ & $<3.53 \mathrm{E}-05$ & $\mathrm{Na}$ & $\mathrm{n} / \mathrm{a}$ & $\pi / 2$ & $\mathrm{n} / \mathrm{a}$ & $3.53 \mathrm{E}-05$ & U \\
\hline SO6E001025 & & Mercary-203 & uCivg & None & None & n/a & $<1.27 E-05$ & $<1.68 \mathrm{E}-04$ & $\mathrm{n} / \mathrm{a}$ & $\mathrm{Na}$ & $\mathrm{n} / \mathrm{a}$ & $\mathrm{n} / \mathrm{a}$ & $1.68 \mathrm{E}-0.4$ & $U$ \\
\hline SOEE001025 & & Neptundum-237 & uCVig & None & None & $\mathrm{n} / \mathrm{a}$ & $<4.92 E-06$ & $\angle 4.38 E-04$ & $\mathrm{Na}$ & $\mathrm{n} / \mathrm{a}$ & $n / a$ & n/a & $4.38 \mathrm{BE}-04 \mathrm{C}$ & $\mathrm{U}$ \\
\hline SOEE001025 & & Neptunlum-238 & $\mathrm{uCirg}$ & None & None & $\mathrm{n} / \mathrm{a}$ & $<6.27 \mathrm{E}-05$ & $\angle 7.87 E-05$ & $\mathrm{n} / \mathrm{a}$ & $\mathrm{n} / \mathrm{a}$ & $\pi / \mathrm{a}$ & nia & 7.87E-05 & U \\
\hline S06E001025 & & Neptunium-239 & $\mathrm{uCVg}$ & Nones & None & $\mathrm{n} / \mathrm{a}$ & $<2.27 \mathrm{E}-05$ & $\angle 2.49 E .04$ & $\mathrm{n} / \mathrm{a}$ & $\mathrm{n} / \mathrm{a}$ & $n / \mathrm{s}$ & $n / a$ & $2.49 E-04$ & U \\
\hline SO6EOO1025 & & Nloblum-94 & $\mathrm{uCV} / \mathrm{g}$ & None & None & $n / a$ & $<1.68 \mathrm{E}-05$ & $<2.63 E-05$ & $\mathrm{n} / \mathrm{s}$ & $n / a$ & $\pi / 2$ & nia & $2.63 \mathrm{E}-05 \mathrm{I}$ & U \\
\hline SO6E001025 & & Plutonium-239 & uCVg & None & None & $\mathrm{n} / \mathrm{a}$ & $<0.0900$ & $<1.02$ & $\mathrm{n} / \mathrm{a}$ & $\pi / a$ & $\pi / a$ & $n / a$ & 1.02 & U \\
\hline SO6EO01025 & - & Potassium-40 & uCivg & None & None & na & $\angle 4.56 \mathrm{E}-04$ & $<4.32 \mathrm{E}-04$ & $\mathrm{~N} / \mathrm{a}$ & $\mathrm{Na}$ & $\mathrm{n} / \mathrm{a}$ & $n / a$ & $4.32 \mathrm{E}-04$ & U \\
\hline S06E001025 & & Protactinium-233 & uCVIg & None & None & $n / a$ & $<2.55 \mathrm{E}-05$ & $<3.65 \mathrm{E}-04$ & $\mathrm{n} / \mathrm{a}$ & $\mathrm{n} / \mathrm{a}$ & $\pi / a^{\prime}$ & $n / a$ & $3.65 \mathrm{E}-04$ & U \\
\hline SO6E001025 & & Protactinium-234 & uCV/g & None & None & $n / a$ & $<3.09 E-03$ & $\angle 3.32 \mathrm{E}-03$ & $\mathrm{n} / \mathrm{a}$ & $\mathrm{n} / \mathrm{a}$ & $n / a$ & $\mathrm{n} / \mathrm{a}$ & 3.32E-03 & $U$ \\
\hline SO6E001025 & & Radium-224 & uCi/g & None & None & $n / a$ & $<2,45 E-04$ & $\angle 3.01 E-03$ & na & $\mathrm{n} / \mathrm{a}$ & $\pi / a$ & $n / a$ & $3.01 \mathrm{E}-03$ & $u$ \\
\hline
\end{tabular}

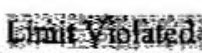


DSR - 20060609

702AZ TRAIN

Sample Group: 20060609.

Core Number: 20060609

Sample Portion: Speclal Sample (rotal)

Customer Sample ID: 702-AZ-1

\begin{tabular}{|c|c|c|c|c|c|c|c|c|c|c|c|c|c|c|c|}
\hline \multirow[b]{2}{*}{ Sample\# $\mathbf{R}$} & \multirow[b]{2}{*}{ An } & \multirow{2}{*}{ Analyte } & \multirow{2}{*}{ s. } & \multirow[b]{2}{*}{ Unik } & \multicolumn{2}{|c|}{ Control Limits } & \multirow[b]{2}{*}{ Standard $x$} & \multirow[b]{2}{*}{ Blank } & \multirow[b]{2}{*}{ Result } & \multirow[b]{2}{*}{ Duplicate } & \multirow[b]{2}{*}{ Average } & \multirow[b]{2}{*}{ RPD $\times$} & \multirow[b]{2}{*}{ Sph Rec $\%$} & \multirow[b]{2}{*}{ Det LImit } & \multirow[b]{2}{*}{ Qual Flags } \\
\hline & & & & & Lower & Upper & & & & & & & & & \\
\hline SO6E001025 & & Radium-226 & & uCilg & None & None & $n / a$ & $<2.72 E-04$ & $<3.29 E-03$ & $\mathrm{n} / \mathrm{a}$ & $\mathrm{n} / \mathrm{a}$ & $n / a$ & n/a & $3.29 E-03$ & $\bar{U}$ \\
\hline S06E001025 & & Rubidium/Rhodium-106 & & uCi/g & None & None & $\mathrm{n} / \mathrm{a}$ & $<3.04 E-04$ & $<2.51 \mathrm{E}-03$ & $\mathrm{n} / \mathrm{a}$ & $\mathrm{N} / \mathrm{a}$ & $\mathrm{Na}$ & n/a & $2.51 E-03$ & U \\
\hline SO6E001025 & & Ruthenium-103 & & uCifg & None & None & n/a & $<1.48 \mathrm{E}-0 \mathrm{~S}$ & $<2.29 E-04$ & $n / a$ & $\mathrm{n} / \mathrm{a}$ & nia & $n / a$ & $2.29 \mathrm{E}-04$ & $\mathbf{U}$ \\
\hline S06E001025 & & Scandium-46 & & $\mathrm{uCi} / \mathrm{g}$ & None & None & $n / a$ & $<2.29 \mathrm{E}-05$ & $<2.25 E-05$ & $\mathrm{n} / \mathrm{a}$ & nas & $n / a$ & $\mathrm{n} / \mathrm{a}$ & $2.25 \mathrm{E}-05$ & U \\
\hline SO6E001025 & & Selenium-75 & & ucils $/ 9$ & None & None & n/a & $<1.63 E-05$ & $<2.10 E-04$ & $\mathrm{n} / \mathrm{a}$ & $n / a$ & $n / a$ & n/a & $2.10 E-04$ & u \\
\hline SO6E001025 & & Gelenium-79 & + & uCl/g & None & None & $\mathrm{n} / \mathrm{a}$ & $<1.33 E-03$ & $<0.0151$ & $\mathrm{n} / \mathrm{a}$ & $\mathrm{Na}$ & nat & na & 0.0151 & $\mathrm{u}$ \\
\hline SO6E004025 & & Silver-108 & & $\mathrm{uCl} / 9$ & None & None & $\pi / 9$ & $<1.81 E-05$ & $<3.48 E-05$ & $n / a$ & $\mathrm{nat}$ & $\mathrm{N} / \mathrm{a}$ & $n / a$ & $3.46 E-05$ & U \\
\hline SO6E001025 & & Silver-110 & & $\mathrm{uCl} / \mathrm{g}$ & None & None & n/a & $<1.66 \mathrm{E}-05$ & $<1.32 E-03$ & $\mathrm{n} / \mathrm{a}$ & $\mathrm{n} / \mathrm{a}$ & $n / a$ & $\mathrm{n} / \mathrm{a}$ & $1.32 E-03$ & $\mathbf{U}$ \\
\hline S06E001025 & & Sodium-22 & & uCVig & None & None & $\mathrm{n} / \mathrm{a}$ & $<2.11 E-05$ & $<2.34 E-05$ & $\mathrm{n} / \mathrm{a}$ & $\mathrm{n} / \mathrm{a}$ & n/a & $\pi / a$ & $2.34 E-05$ & $\bar{U}$ \\
\hline SO66E001025 & & Sodium-24 & & uCl/g & None & None & $n / a$ & $<2,08 E-05$ & $<2.16 \mathrm{E}-05$ & $\mathrm{nva}$ & $\mathrm{n} / \mathrm{a}$ & $\mathrm{n} / \mathrm{a}$ & $\mathrm{n} / \mathrm{a}$ & $2.16 E-05$ & U \\
\hline S06E001025 & & Strontium-85 & & uCi/g & None & None & $\mathrm{n} / \mathrm{a}$ & $<1.82 E-05$ & $<1.90 E-04$ & $\mathrm{n} / \mathrm{a}$ & $n / a$ & n/a & $n / a$ & $1.90 E-04$ & $U$ \\
\hline S06E00 +025 & & Tantalum-182 & & uCi/g & None & None & $n / a$ & $<6.33 E-05$ & $<6.41 E-05$ & $n / a$ & n/a & nal & $\mathrm{Na}$ & $3,41 \mathrm{E}-0.5$ & U \\
\hline S06E001025 & & Tellurium-123 & & uCi/g & None & None & $n / a$ & $<9.11 \mathrm{E}-0 \mathrm{~B}$ & $<1.01 E-04$ & $\mathrm{n} / \mathrm{a}$ & $n / a$ & $n / a$ & $n / a$ & $1.01 \mathrm{E}-04$ & $\bar{U}$ \\
\hline SOEEDO1025 & & Teflurium-125 & & uCilg & None & None & $n / a$ & $<1.72 \mathrm{E}-05$ & $\angle 2.59 E-04$ & $n / a$ & $\mathrm{n} / \mathrm{a}$ & n/a & $\mathrm{n} / \mathrm{a}$ & $2.59 \mathrm{E}-04$ & $u$ \\
\hline SOEE001025 & & Thallium-208 & & $\mathrm{uCv} / \mathrm{g}$ & None & None & $n / a$ & $<1.97 E-05$ & $<1.56 \mathrm{E}-04$ & $n / a$ & $n / a$ & $n / a$ & $\mathrm{n} / \mathrm{a}$ & $1.56 \mathrm{E}-04$ & U \\
\hline SC6E001025 & & Thorium-228 & & uCisg. & None & None & $n / a$ & $<4.64 E-04$ & C5.71E-03 & $\mathrm{n} / \mathrm{a}$ & $\mathrm{n} / \mathrm{a}$ & na & $n / 2$ & $5.71 E-0.3$ & U \\
\hline SO6E00t025 & & Thorium-229 & & uCirg & None & None & n/a & $<4,42 E-05$ & $\angle 4.83 E-04$ & n/a & $n / a$ & n/a & $n / a$ & 4.83E-04 & $\bar{U}$ \\
\hline SO6E001025 & & Thorium-234 & & uCi/g & None & None & n/a & $<1.85 E-04$ & $<1.42 E-03$ & $n / a$ & $n / \mathrm{a}$ & n/a & $\mathrm{n} / \mathrm{a}$ & $1,42 \mathrm{E}-03$ & $\mathrm{U}$ \\
\hline SO6E001025 & & Tin-113 & & ucl/g & None & None & $\mathrm{Na}$ & $<1.67 E-05$ & $<2.96 \mathrm{E} \cdot 04$ & $n / a$ & $\mathrm{n} / \mathrm{a}$ & $n / a$ & nia & 2.96E-04 & U \\
\hline SO6E001025 & & Tin-126 & & ucilg & None & None & n/a & $<1.19 E-05$ & $<1.16 \mathrm{E}-04$ & $n / a$ & $\mathrm{n} / \mathrm{a}$ & $\mathrm{n} / \mathrm{a}$ & $\mathrm{n} / \mathrm{a}$ & $1.18 E-04$ & $\mathbf{u}$ \\
\hline SO6E001025 & & Uranium-232 & & uCilg. & None & None & $\mathrm{n} / \mathrm{a}$ & $<3.74 E-03$ & $\angle 0.02 B D$ & $\mathrm{n} / \mathrm{a}$ & $\mathrm{n} / \mathrm{a}$ & $\mathrm{N} / \mathrm{a}$ & $\mathrm{n} / \mathrm{a}$ & 0.0280 & 0 \\
\hline S06E001025 & & Uranium-235 & & uCi/g & None & None & $n / \mathrm{a}$ & $<1.67 \mathrm{E}-05$ & $<1.98 E-04$ & $n / a$ & na & $n / a$ & $\mathrm{n} / \mathrm{a}$ & $\therefore .98 E-04$ & U \\
\hline SO6E 001025 & & Uranium-237 & & uCilg & None & None & $n / a$ & $<1,82 E-0.5$ & $<2.17 \mathrm{E}-04$ & $n / a$ & n'a & n/a & $n / a$ & $2.17 E-04$ & U \\
\hline S06E001025 & & Uranlum/Thorium-233 & & $\mathrm{uCi} / \mathrm{g}$ & None & None & $\mathrm{n} / \mathrm{a}$ & $<7.70 E-03$ & $<0.109$ & $n / a$ & $n / a$ & $n / a$ & $\mathrm{n} / \mathrm{a}$ & 0.109 & $\bar{u}$ \\
\hline SO6E001025 & & Xenon-131 & & uCig & None & None & $\mathrm{n} / \mathrm{a}$ & $<3.68 \mathrm{E}-04$ & $<4.44 E-03$ & $n / a$ & $n / a$ & $\mathrm{~N} / \mathrm{a}$ & n/a & 4.44E-03 & $\bar{U}$ \\
\hline SO6E001025 & & Yttrium-88 & & $\mathrm{uCi} / \mathrm{g}$ & None & None & na & $<1.68 E-05$ & $\angle 1.48 E-05$ & $\mathrm{n} / \mathrm{a}$ & na & $\mathrm{n} / \mathrm{a}$ & $\mathrm{n} / \mathrm{a}$ & $1.48 \mathrm{E}-0.5$ & $\bar{U}$ \\
\hline SOOE001025 & & Yttrium-91 & & uCi/g & None & None & n/a & $<7.67 E-03$ & $\angle 6.91 \mathrm{E}-03$ & $\mathrm{n} / \mathrm{a}$ & $\mathrm{n} / \mathrm{a}$ & ;/a & $\mathrm{n} / \mathrm{a}$ & 6.91E-03 & $\bar{U}$ \\
\hline S06E001025 & & Zinc-65 & & uCilg & None & None & $\pi / \mathrm{a}$ & $\angle 4.41 \mathrm{E}-05$ & $\angle 4.41 \mathrm{E}-05$ & $n / a$ & $n / a$ & $\mathrm{n} / \mathrm{a}$ & $\mathrm{n} / \mathrm{a}$ & 4.41E-05 & $u$ \\
\hline
\end{tabular}

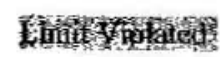


DSR - 20060609

702AZ TRAIN

\section{Sample Group: 20060609}

Core Number: 20060609

Sample Portion: Special Sample (Total)

Customer Sample ID: 702-AZ-1

\begin{tabular}{|c|c|c|c|c|c|c|c|c|c|c|c|c|c|c|}
\hline \multirow[b]{2}{*}{ SSamplew $R$} & \multirow[b]{2}{*}{ ANI } & \multirow{2}{*}{ Analyte } & \multirow[b]{2}{*}{ Unit } & \multicolumn{2}{|c|}{ Controd Limits } & \multirow{2}{*}{ Standard $x$} & \multirow[b]{2}{*}{ Blank: } & \multirow[b]{2}{*}{ Result } & \multirow[b]{2}{*}{ Duplicate } & \multirow[b]{2}{*}{ Average } & \multirow[b]{2}{*}{ RPD $\%$} & \multirow[b]{2}{*}{ Spk Rec * } & \multirow{2}{*}{ Dot Limlt } & \multirow[b]{2}{*}{ Qual Flags } \\
\hline & & & & Lower & Upper & & & & & & & & & \\
\hline SD6E001025. & & ZirconiumiNiobium-95 & UCVig & None & None & $n$ a & $<3.27 E-05$ & $<5.68 \mathrm{E}-05$ & $\mathrm{n} / \mathrm{a}$ & n/a & $\mathrm{n} / \mathrm{a}$ & $n / a$ & $5.68 \mathrm{E}-05 \mathrm{~L}$ & ju \\
\hline S06E001025 & & $\mathrm{pH}$ & $\mathrm{pH}$ & Mone & None & $n / a$ & $\mathrm{~N} / \mathrm{a}$ & 3.93 & 3.95 & 3.94 & 0.508 & $\mathrm{n} / \mathrm{a}$ & 0.0100 & \\
\hline SO6E001025 & & Polarized Light Microscapy & & None & None & $n / a$ & $\mathrm{n} / \mathrm{a}$ & Complete & $\mathrm{n} / \mathrm{a}$ & n/a & $\mathrm{n} / \mathrm{a}$ & $n / a$ & n/a & \\
\hline S06E001025 & & Scanning Electron Mienoscope & & None & None & $\mathrm{n} / \mathrm{a}$ & n/a & Complate & $n / a$ & n/a & $n / a$ & $n / a$ & na) & \\
\hline S06E001025 & & Phase ID by $X$-ray Diffraction & & Hone & None & $n / \mathrm{a}$ & $\mathrm{n} / \mathrm{a}$ & Complete & $n / a$ & $\mathrm{n} / \mathrm{a}$ & $\mathrm{n} / \mathrm{a}$ & $n / a$ & $\mathrm{n} / \mathrm{a}$ & \\
\hline S06E001025 & & Diffierential Scanning Calorimetry E & Joules/g & None & None & $\mathrm{n} / \mathrm{a}$ & n/a & $9.05 E+02$ & $1.04 E+03$ & $9.73 E+02$ & 14.0 & $n / 2$ & n/a & \\
\hline S06E001025 & & \%WATER & $\%$ & None & None & 99.0 & $n / a$ & 100 & 100 & 100 & 0.100 & $n / a$ & 0.0100 & \\
\hline $806 E 001025$ & & Total inorganic Carbon & $\log / 9$ & None & None & 101 & $<5.00$ & 224 & 285 & 254 & 24.0 & 101 & $42.0 \mathrm{~s}$ & \\
\hline S06E001025 & & Tatal Organic Carbon & $\log / 9$ & None & None & 95.0 & $<40.0$ & $2.32 E+04$ & $2.38 E+04$ & $2.36 E+04$ & 2.55 & 54.7 & 336 & \\
\hline SO6E001027 & 0 & PCB Prep for Scroening & & None: & None & $n / \theta$ & $n / a$ & EGATINE & $\mathrm{n} / \mathrm{a}$ & $\mathrm{n} / \mathrm{s}$ & $n / \mathrm{a}$ & $n / 2$ & 0.0100 & Q \\
\hline S06E001046 & & Differential Scanning Calorlmetry E & Joules/g & None & None & $\mathrm{n} / \mathrm{a}$ & n/a & 523 & $\mathrm{n} / \mathrm{a}$ & $n / a$ & $n / 2$ & $\mathrm{n} / \mathrm{a}$ & $n / a$; & \\
\hline
\end{tabular}

\section{Customer Sample ID: 702-AZ-1 ACID}

\begin{tabular}{|c|c|c|c|c|c|c|c|c|c|c|c|c|c|c|c|}
\hline \multirow{2}{*}{ 8.mplea R } & \multirow[b]{2}{*}{ An } & \multirow[b]{2}{*}{ Analyte } & \multirow{2}{*}{$\cdots$} & \multirow[b]{2}{*}{ Unia } & \multicolumn{2}{|c|}{ Contral Limits } & \multirow[b]{2}{*}{ Standard $x$} & \multirow[b]{2}{*}{ Blank } & \multirow[b]{2}{*}{ Result [ } & \multirow[b]{2}{*}{ Duplicate } & \multirow[b]{2}{*}{ Avernge } & \multirow[b]{2}{*}{ RPO \% } & \multirow[b]{2}{*}{ Spk Rec \% } & \multirow[b]{2}{*}{ Det Limlir } & \multirow[b]{2}{*}{ Qual Flags } \\
\hline & & & & & Lower & Upper & & & & & & & & & \\
\hline S06EOD1035 & $A$ & Aluminitum & 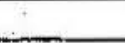 & ug/g & None & None & 97.2 & $<D .0270$ & $<5.37$ & $<5.20$ & $n / a$ & 3.33 & 94.9 & $5.37 \mathrm{~T}$ & $U$ \\
\hline S06E 001035 & A & Antimony & & $\mathrm{ug} / \mathrm{g}$ & None & None & 92.9 & $\angle 0.0280$ & $<5.57$ & $<5.39$ & $n / a$ & 3.33 & 81.3 & 5.570 & $u$ \\
\hline S06E001035 & $A$ & Arsonic & & $u g / g$ & None & None & 103 & $<0.0590$ & $<11.7$ & $<11.4$ & $n / a$ & 3.33 & 102 & 11.70 & $\bar{u}$ \\
\hline S06E001035 & $A$ & Barium & & $u g / g$ & None & None & 96.6 & $<7.00 E-03$ & 7.53 & 7.05 & 7.29 & 6.60 & 93.4 & $1.39 \mathrm{~J}$ & $\mathrm{~J}$ \\
\hline S06E001035 & A & Beryltium & 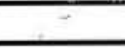 & $u g / g$ & None & None & 104 & $<1.20 \mathrm{E}-03$ & $<0.239$ & $\infty 0.231$ & $\mathrm{n} / \mathrm{a}$ & 3.33 & 99.9 & 0.239 & $\mathrm{U}$ \\
\hline S06E001035 & A & Bismuth & 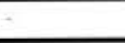 & $\mathrm{ug} / \mathrm{g}$ & None & None & 90.1 & $<0.102$ & $<20.3$ & $<18.6$ & $\mathrm{n} / \mathrm{a}$ & 3.32 & 86.6 & 20.30 & $U$ \\
\hline S06E001035 & $A$ & Boron & & ug/g & None & None & 92.1 & $<0.0180$ & 534 & 505 & 519 & 5.59 & 95.5 & 3.58 & 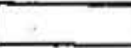 \\
\hline S06E001035 & A & Cadmium & - & $\mathrm{wg} / \mathrm{g}$ & Nane & None & 92.9 & $\angle 3.00 \mathrm{E}-03$ & $<0.597$ & $<0.577$ & $\mathrm{~N} / \mathrm{a}$ & 3.33 & 20.7 & 0.5974 & u \\
\hline S06E001035 & $\mathrm{A}$ & Calcium & , & ug/g & None & None & 116 & $<0.0800$ & $1.36 E+03$ & 1.33E+03 & $1.34 \mathrm{E}+03$ & 2.63 & 131 & $15.9 \mathrm{~b}$ & be \\
\hline SO6E001035 & $A$ & Cerium & 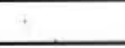 & uglg & None & None & 98.1 & $<0.0150$ & $<2.98$ & 2.89 & $\mathrm{n} / \mathrm{a}$ & 3.33 & 92.8 & $2.98 \mathrm{U}$ & U \\
\hline SO6E001035 & A & Chromium & & $\mathrm{ug} / \mathrm{g}$ & None & Mone & 96.5 & 40.0140 & 120 & $<269$ & 7.35 & 127 & 92.8 & $2.79 \mathrm{~J}$ & $J$ \\
\hline SO6E001035 & A & Coball & - & ugig & Nane & None & 94.2 & $\angle 8.00 E-03$ & $<1.59$ & $<.54$ & $\mathrm{n} / \mathrm{a}$ & 3.32 & 91.7 & $1.59 \mathrm{U}$ & u \\
\hline SO6E001035 & $\mathrm{A}$ & Copper & & ugig & None & None & 94.7 & $<0.0140$ & 14.1 & 13.5 & 13.8 & 3.74 & 92.2 & $2.79 \mathrm{~J}$ & \\
\hline
\end{tabular}

Emint Violat? 
05 - Dec- 2006 8:16:11

DSRHandcopyWLimits 2.0

Sample Group: 20060609

Core Number: 20060609

\section{Sample Portion: Special Sample (Total)}

Customer Sample ID: 702-AZ-1 ACID

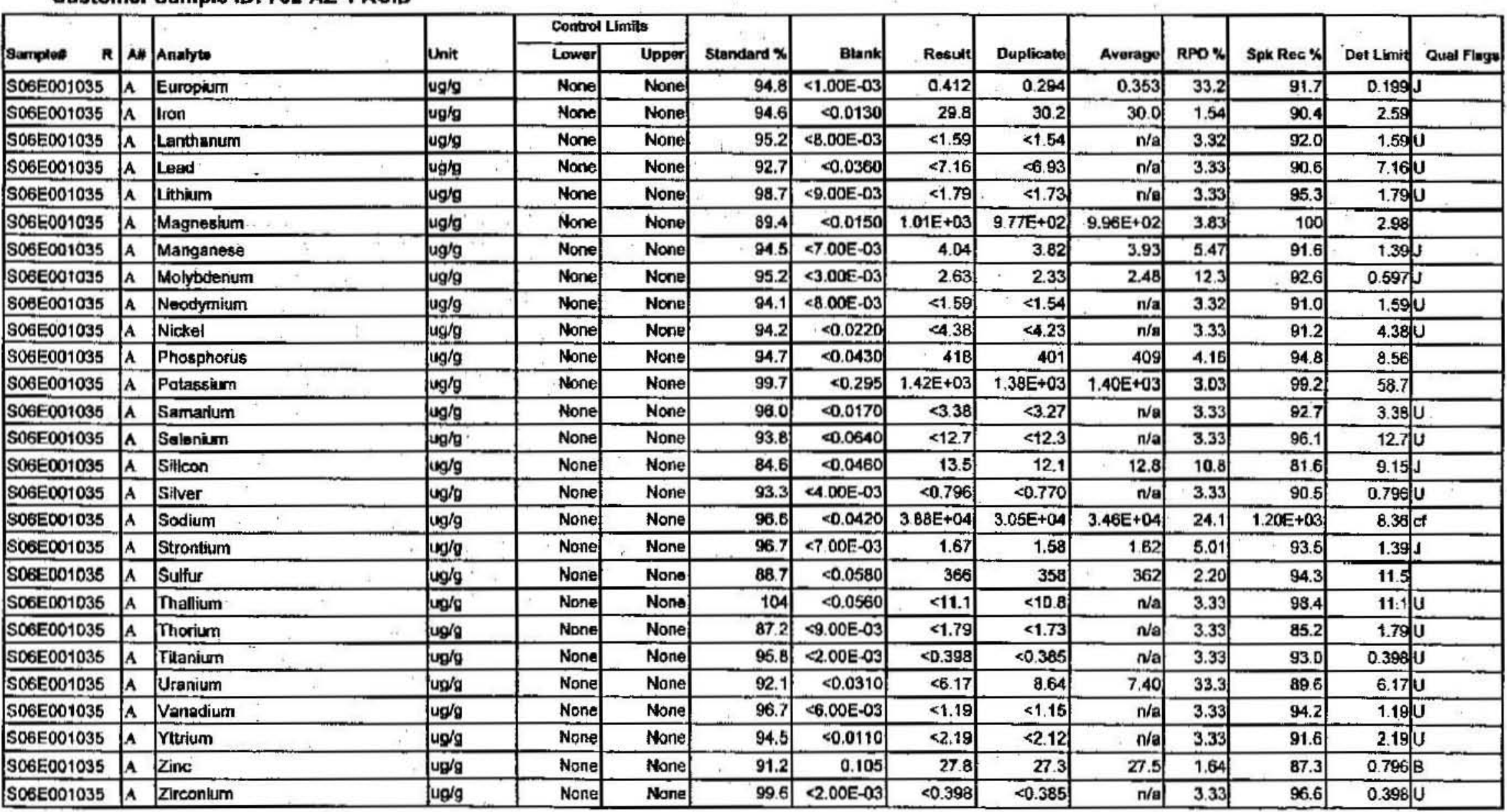

\section{Fum Xiolated}


DSR - 20060609

T02AZ TRAIN

Sample Group: 20060609

Core Number: 20060609

Sample Portion: Special Sample (Total)

Customer Sample ID: 702-AZ-1 NH4

\begin{tabular}{|c|c|c|c|c|c|c|c|c|c|c|c|c|c|c|}
\hline \multirow[b]{2}{*}{ Samples $R$} & \multirow[b]{2}{*}{ a\# } & \multirow{2}{*}{ Analyte } & \multirow[b]{2}{*}{ Unit } & \multicolumn{2}{|c|}{ Control Limfits } & \multirow[b]{2}{*}{ Standard $\%$} & \multirow[b]{2}{*}{ Blank } & \multirow[b]{2}{*}{ Result] } & \multirow[b]{2}{*}{ Duplicate } & \multirow[b]{2}{*}{ Average } & \multirow[b]{2}{*}{ RPD \% } & \multirow[b]{2}{*}{ Spk Rec $x$} & \multirow[b]{2}{*}{ Det Liming } & \multirow[b]{2}{*}{ Qual Fluggs } \\
\hline & & & & Lower & Upper & & & & & & & & & \\
\hline $06 E 001034$ & $\mathrm{~s}$ & Ammonium ton & ug fg & Nane & None & 102 & $<6.44 E-03$ & $1.97 E+05$ & $1.64 \mathrm{E}+05$ & $1.81 E+05$ & 18.2 & 115 & 0.725 & \\
\hline
\end{tabular}

Customer Sample ID: 702-AZ-1 SVOA

\begin{tabular}{|c|c|c|c|c|c|c|c|c|c|c|c|c|c|c|}
\hline \multirow{2}{*}{ Sarnple\# R } & \multirow[b]{2}{*}{ A\# } & \multirow[b]{2}{*}{ Annlyte } & \multirow[b]{2}{*}{ Unit } & \multicolumn{2}{|c|}{ Control Limilts } & \multirow[b]{2}{*}{ Standard $\%$} & \multirow[b]{2}{*}{ Blank } & \multirow[b]{2}{*}{ Result } & \multirow[b]{2}{*}{ Duplicate } & \multirow[b]{2}{*}{ Averaga| } & \multirow[b]{2}{*}{ RPD \% } & \multirow[b]{2}{*}{ Spk Rec $\%$} & \multirow[b]{2}{*}{ Det Limif } & \multirow[b]{2}{*}{ Qual Fiags } \\
\hline & & & & Lower & Upper & & & & & & & & & \\
\hline S06E001037 & & Alpha/Beta Organic Scan & & None & None & $\mathrm{n} / \mathrm{a}$ & $\mathrm{n} / \mathrm{a}$ & Complete & na & niạ & $\mathrm{n} / \mathrm{g}$ & $n / a$ & $n / a$ & \\
\hline S06E001037 & o & 1,2,4-Tnchiorobenzens & ug/Kg. & None & None & 74.8 & $<1.62 \mathrm{E}+03$ & $<908$ & $\mathrm{n} / \mathrm{a}$ & n/a & $\mathrm{n} / \mathrm{a}$ & 79.8 & 9081 & u \\
\hline S06E001037 & o & 1,2-Dichlarobenzene & $\mathrm{ug} / \mathrm{Kg}$ & None & None & $n / \mathrm{a}$ & $<2.78 E+03$ & $<1.54 E+03$ & $\mathrm{n} / \mathrm{a}$ & $\mathrm{n} / \mathrm{a}$ & $n / a$ & $\mathrm{n} / \mathrm{a}$ & $1.54 \mathrm{E}+03$ & $\bar{u}$ \\
\hline SO6E001037 & o & 1,4-Dichlorobenzene & ugho & None & None & 71.3 & $<1.67 E+03$ & $<935$ & $\mathrm{n} / \mathrm{a}$ & . $n / 2$ & $n / B$ & 72.8 & 935) & U \\
\hline SO6EOD1037 & 0 & 2,2'-oxybis(1-Chioropropana) & ug $/ \mathrm{Kg}$. & None & None & $n$ ta & $<1.98 E+03$ & $<1.11 E+03$ & naa & $\mathrm{Na}$ & $n / a$ & $\mathrm{n} / \mathrm{a}$ & $1.11 E+0 \sin$ & $u$ \\
\hline S06E001037 & o & 2,4,5-Trichlorophenot & fug/Kg & Mone & None & $n / a$ & $<1.56 \mathrm{E}+03$ & $<873$ & $\mathrm{n} / \mathrm{s}$ & n/a & $\mathrm{n} / \mathrm{a}$ & $\overrightarrow{n / a}$ & 873 & $\mathrm{U}$ \\
\hline SO6E00t037 & 0 & 2,4,6-Trichlorophenol ... & $\log / K_{g}$ & None & None & $\pi / \mathrm{a}$ & $<1.62 E+03$ & $<905$ & $n / 2$ & 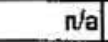 & $\mathrm{n} / \mathrm{a}$ & $n / 2$ & $905 \mathrm{~L}$ & $u$ \\
\hline S06E001037 & o & 2,4-Dichiorophenol & ug $/ K_{g}$ & None & None & $\mathrm{n} / \mathrm{a}$ & $<1.51 E+03$ & $<B 46$ & $n / a$ & n/a & $\mathrm{n} / \mathrm{a}$ & $\mathrm{n} / \mathrm{a}$ & 846.1 & U \\
\hline S06E001037 & o & 2,4-Dimethylphanol & uog/Kg & Nons & None & $n / a$ & $<1.18 E+03$ & $<661$ & $\mathrm{n} / \mathrm{a}$ & n/a & $n / a$ & $n / a$ & $661 / \mathrm{L}$ & $\mathrm{U}$ \\
\hline SO6E001037 & 0 & 2.4-Dinitrophenol & $\operatorname{cog} / \mathrm{Kg}$ & None & None & $\mathrm{n} / \mathrm{a}$ & $<823$ & $<461$ & $\mathrm{n} / \mathrm{a}$ & $\mathrm{n} / \mathrm{a}$ & $\mathrm{n} / \mathrm{a}$ & $n / 2$ & 461 L & $u$ \\
\hline SO6E001037 & o & 2,4-Dinitrotoluene & ugg/Kg & None & Nons & 97.0 & $<1.79 E+03$ & $<999$ & nia & $\mathrm{n} / \mathrm{a}$ & $n / a$ & 85.7 & 999 & 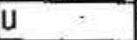 \\
\hline SO6E001037 & 0 & 2,6-Dinitrololuene & $\log / \mathrm{Kg}$ & None & None & $\mathrm{n} / \mathrm{a}$ & $<1.72 \mathrm{E}+03$ & $<962$ & $\mathrm{n} / \mathrm{a}$ & $n / a$ & $\mathrm{n} / \mathrm{a}$ & $n / 8$ & 962 L & $\underline{u}$ \\
\hline SO6E001037 & 0 & 2-Butoxyethenol & $\operatorname{ug} / \mathrm{Kg}$ & None & Nons & $n / a$ & $<3.01 E+04$ & $\angle 1.68 E+0.4$ & n/a & $\mathrm{n} / \mathrm{a}$ & $n / a$ & 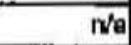 & $1.6 \mathrm{aE}+04 \mathrm{c}$ & $\bar{u}$ \\
\hline SO6E001037 & 0 & 2-Chloronaphthalene & $\operatorname{cog} / \mathrm{Kg}$ & None & None & $\mathrm{n} / \mathrm{a}$ & $<1.64 \mathrm{E}+03$ & $<919$ & $n / a$ & n/a & $n / a$ & $\mathrm{~N} / \mathrm{a}$ & g1: 1 & u \\
\hline SOGE001037 & 0 & 2-Chlorophenol & $\log / \mathrm{Kg}$ & None & None & 782 & $<1.63 E+03$ & $<914$ & $n / a$ & na & $n+a$ & 89.8 & $914 \mathrm{~T}$ & $\mathbf{U}$ \\
\hline SO6E001037 & 0 & 2-Methyinaphthalene & ugg/Kg & None & None & $\mathrm{N} / \mathrm{a}$ & $<1.73 E+03$ & $<969$ & $\mathrm{n} / \mathrm{a}$ & $\mathrm{N} / \mathrm{a}$ & n/a & $n / a$ & $969]$ & U \\
\hline S06E001037 & 0 & 2-Methylphenol & ug/Kg & None & None & $\mathrm{n} / \mathrm{B}$ & $<1.70 E+a_{3}$ & $<952$ & $\mathrm{n} / \mathrm{a}$ & $n / 9$ & $\mathrm{~N} / \mathrm{a}$ & $\mathrm{N} / \mathrm{a}$ & 952 & $\bar{U}$ \\
\hline SO6E001037 & 0 & 2-Nitroanlline & fug/Kg & None & None & n/a & $<1.75 E+03$ & $<980$ & $\mathrm{n} / \mathrm{a}$ & $n i a$ & $\mathrm{n} / \mathrm{a}$ & $\mathrm{n} / \mathrm{a}$ & $980 \mathrm{~T}$ & $\bar{U}$ \\
\hline S06ED01037 & 0 & 2-Nitrophenol & ug/kg & None & None & n/a & $<1.50 E+03$ & $<840$ & $\mathrm{n} / \mathrm{a}$ & n/a & $n / a$ & $n / a$ & 8404 & $\bar{u}$ \\
\hline S06E001037 & 0 & 3 \& 4 Methylphenol Total & ug/Kg & None & None & nia & $<1.65 \mathrm{E}+03$ & $<922$ & $n / \mathrm{a}$ & nia & $n+a$ & $n / a$ & $922 \mathrm{~L}$ & $\mathrm{U}$ \\
\hline SO6ED01037 & 0 & 3-Nitroaniline & ug $/ \mathrm{Kg}$ & None & None & $\mathrm{n} / \mathrm{a}$ & $<987$ & $<552$ & $n / \mathrm{a}$ & $\mathrm{n} / \mathrm{a}$ & $\mathrm{n} / \mathrm{a}$ & $\mathrm{n} / \mathrm{a}$ & 5521 & $\mathrm{U}$ \\
\hline S06E001037 & 0 & 4.6-Dinitro-2-methylphenol & $u g / \mathrm{Kg}$ & None & None & n/a & $<1.19 \mathrm{E}+03$ & 4663 & $n / a$ & nat & $n / a$ & $n / a$ & 6634 & U \\
\hline SO6E001037 & 0 & 4-Bromophenyl-phenylether & ug/Kg & None & None & $n / a$ & $<1.72 E+03$ & $<963$ & $\mathrm{n} / \mathrm{a}$ & $\mathrm{n} / \mathrm{a}$ & $\mathrm{n} / \mathrm{a}$ & $\mathrm{n} / \mathrm{a}$ & $963 \mathrm{l}$ & U \\
\hline
\end{tabular}

Stinivitiolated 


\section{Sample Group: 20060609}

Core Number: 20060609

Sample Portion: Special Sample (Total)

Customer Sample ID: 702-AZ-1 SVOA

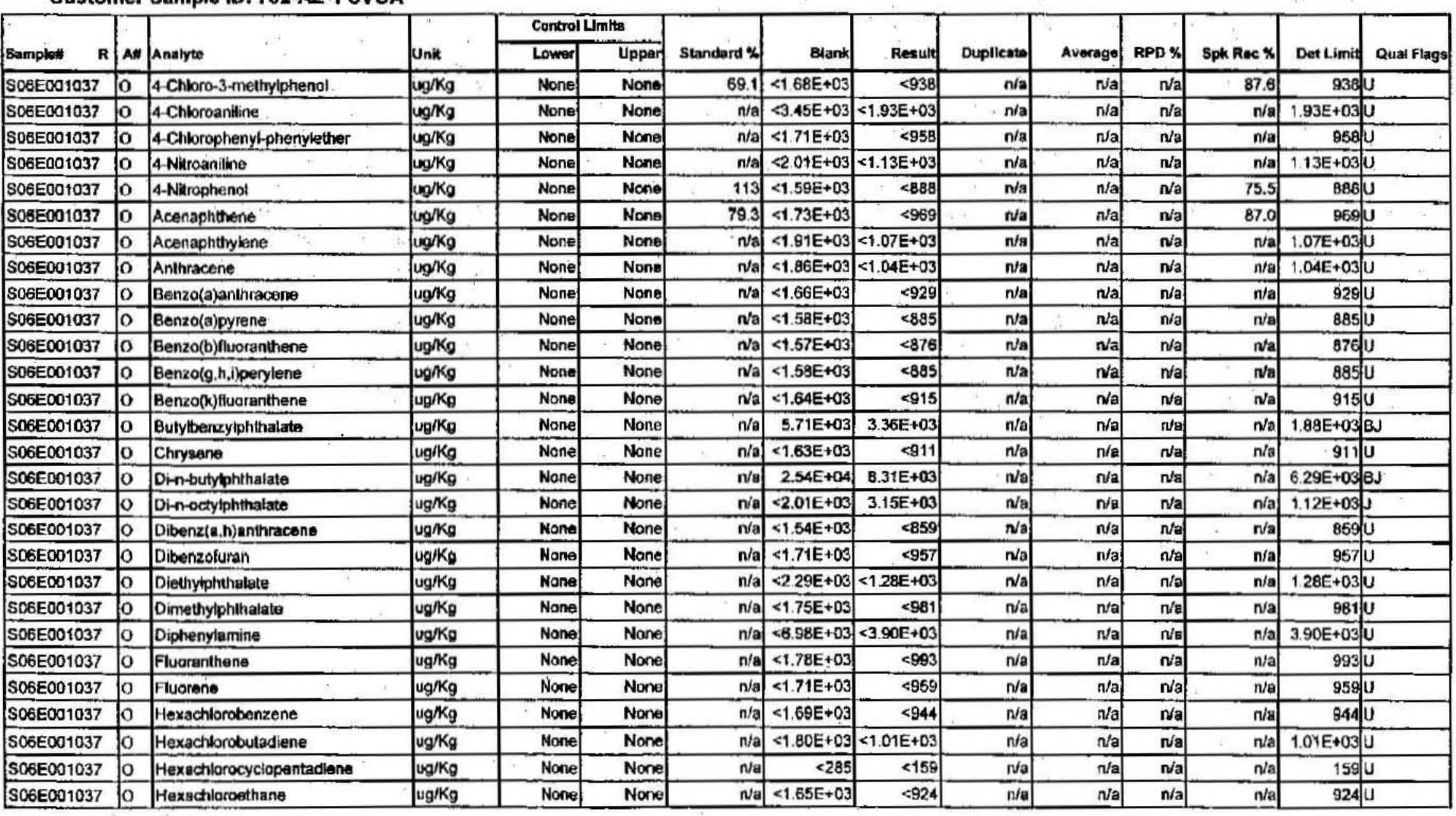

Endvolated 
DSR - 20060609

T02AZ TRAIN

\section{Sample Group: 20060609}

Core Number: 20060609

\section{Sample Portlon: Speclal Sample (Total)}

Customer Sample ID: 702-AZ-1 SVOA

\begin{tabular}{|c|c|c|c|c|c|c|c|c|c|c|c|c|c|c|}
\hline \multirow[b]{2}{*}{ Sampled $R$} & \multirow[b]{2}{*}{ A*t } & \multirow[b]{2}{*}{ Anahyte } & \multirow[b]{2}{*}{ Unie } & \multicolumn{2}{|c|}{ Control Limits } & \multirow[b]{2}{*}{ Standard $\%$} & \multirow[b]{2}{*}{ Blank } & \multirow[b]{2}{*}{ Result } & \multirow[b]{2}{*}{ Duplieata } & \multirow[b]{2}{*}{ Average } & \multirow[b]{2}{*}{ RPD $\%$} & \multirow[b]{2}{*}{ Spk Rec $\%$} & \multirow[b]{2}{*}{ Det Limit } & \multirow[b]{2}{*}{ Qual Flags } \\
\hline & & & & Lower & Upper & & & & & & & & & \\
\hline S06E001037 & 0 & Indeno(1,2,3-cd)pyrene & ug/Kg & None & None & $\mathrm{n} / \mathrm{a}$ & $<1.60 E+03$ & $<895$ & $\mathrm{Na}$ & n/a & $\mathrm{n} / \mathrm{a}$ & $\mathrm{n} / \mathrm{a}$ & 895 & U \\
\hline 506E001037 & 0 & Isophorone & $\mathrm{ug} / \mathrm{Kg}$ & None & None & $\mathrm{n} / \mathrm{a}$ & $<1.54 E+03$ & $<851$ & na & $n / a$ & $n / a$ & $\mathrm{n} / \mathrm{a}$ & $861 \mathrm{~L}$ & $\bar{H}$ \\
\hline $506 \mathrm{E} 001037$ & 0 & N-Nitrosodipropylamine & $\mu g / K_{g}$ & None & None & 80.5 & $<1,60 E+03$ & $<998$ & n/a & $n / a$ & $n / a$ & 80.0 & 896 & $\underline{U}$ \\
\hline S06E001037 & 0 & Naphlthalene & ug $/ \mathrm{Kg}$ & None & None & $n / a$ & $<1.72 E+03$ & <951 & $\mathrm{n} / \mathrm{a}$ & $n / \mathrm{a}$ & $n / a$ & $\mathrm{n} / \mathrm{a}$ & $961: \mathrm{t}$ & u \\
\hline S06E001037 & 0 & Nitrabenzene & $\operatorname{ug} / \mathrm{Kg}$ & None & None & $\pi / a$ & $<1.79 E+03$ & $<998$ & $\mathrm{n} / \mathrm{a}$ & n/a & $\mathrm{n} / \mathrm{a}$ & $\mathrm{n} / \mathrm{a}$ & 998 & $\mathrm{U}$ \\
\hline SO6E 001037 & o. & Pentachlorophenol & ug/Kg & None & None & 88.3 & $<1.34 E+03$ & $<750$ & $\mathrm{Na}$ & n/a & $n / a$ & 88.6 & $750 \mathrm{c}$ & U \\
\hline S06E001037 & 0 & Phenanthrene & $\operatorname{ug} / \mathrm{Kg}$ & None & None & $\mathrm{N} / \mathrm{a}$ & $<1.69 E+03$ & $<84$ & $\mathrm{n} / \mathrm{a}$ & n/a & $\mathrm{na}$ & $n / a$ & 844 & $\mathrm{U}$ \\
\hline SO6E001037 & 0 & Phenod & ug/Kg & None & None & 76.9 & $<1.65 E+03$ & c920 & $\mathrm{n} / \mathrm{a}$ & $n / a$ & naa & 92.1 & 920 & U \\
\hline S06E001037 & 0 & Pyrene & $\log / \mathrm{Kg}$ & None & None & 92.9 & $\angle 1.72 E+03$ & $<960$ & $\mathrm{n} / \mathrm{a}$ & $n / a$ & $n$ ata & 115 & 960 i & $\bar{U}$ \\
\hline S06E001037 & o & Pyrickne & ug/Kg & None & None & $\mathrm{n} / \mathrm{a}$ & $<1.58 \mathrm{E}+03$ & $<884$ & $\mathrm{n} / \mathrm{a}$ & $\mathrm{N} / \mathrm{a}$ & $\mathrm{n} / \mathrm{a}$ & $\mathrm{n} / \mathrm{a}$ & 884 & $\mathbf{U}$ \\
\hline S06E001037 & $a$ & |Tri-n-butylphosphate & ug/Kg & None & None & $n / a$ & $5.38 \mathrm{E}+03$ & $<1.21 E+03$ & $\mathrm{n} / \mathrm{a}$ & naa & $n / a$ & $\mathrm{Na}$ & $1.21 E+03$ & $\mathbf{u}$ \\
\hline S06E001037 & o & bis $\{2$-Chloroethoxy)methane & $\mathrm{ug} / \mathrm{Kg}$ & None & None & $\mathrm{n} / \mathrm{a}$ & $<1.79 \mathrm{E}+03$ & $<1.00 \mathrm{E}+03$ & $\mathrm{n} / \mathrm{a}$ & $\mathrm{n} / \mathrm{a}$ & $\mathrm{Na}$ & $\mathrm{Na}$ & 1000 & $\mathbf{U}$ \\
\hline SO6E001037 & $a$ & bis(2-Ethylhexyl)phthalate & $\log / \mathrm{Kg}$ & None & None & $n / a$ & $<2.49 E+04$ & $<1.39 \mathrm{E}+04$ & $\mathrm{n} / \mathrm{a}$ & $n / a$ & $\mathrm{n} / \mathrm{a}$ & $\mathrm{n} / \mathrm{a}$ & $1.39 \mathrm{E}+04 \mathrm{i}$ & u \\
\hline S06E001037 & a & bis $-(2-$ Chloroethyl) ether & ug/Kg & Nane & None & n/a & $<1.77 \mathrm{E}+03$ & $<991$ & $n / \mathrm{a}$ & n/a & $n / a$ & $\mathrm{n} / \mathrm{a}$ & $991 \mathrm{l}$ & $u$ \\
\hline
\end{tabular}

\section{Customer Sample ID: 702-AZ-1 WATER}

\begin{tabular}{|c|c|c|c|c|c|c|c|c|c|c|c|c|c|c|}
\hline \multirow[b]{2}{*}{ Sample" $\quad \mathbf{R}$} & \multirow[b]{2}{*}{ A* } & \multirow[b]{2}{*}{ Analyto } & \multirow[b]{2}{*}{ Unit } & \multicolumn{2}{|c|}{ Control Limiks } & \multirow[b]{2}{*}{ Standard $x$} & \multirow[b]{2}{*}{ Blank } & \multirow[b]{2}{*}{ Rasult } & \multirow[b]{2}{*}{ Duplicate } & \multirow[b]{2}{*}{ Averaga } & \multirow[b]{2}{*}{ RPD \% } & \multirow[b]{2}{*}{ Spk Rec \% } & \multirow[b]{2}{*}{ Det Limin } & \multirow[b]{2}{*}{ Gual Fiags } \\
\hline & & & & Lower & Upper & & & & & & & & & \\
\hline SD6E001036 & w & Nitrate & ug/g & Nane & None & 101 & $<6.95$ & $5.98 \mathrm{E}+05$ & $6.34 E+05$ & $6.16 \mathrm{E}+05$ & 6.93 & 104 & $5.59 E+03$ & \\
\hline SO6E001036 & $w$ & Acetate & $\mathrm{ug} / \mathrm{g}$ & Nane & None & 96.9 & $<578$ & $<2.36 \mathrm{E}+03$ & $<2.34 E+03$ & $\mathrm{n} / \mathrm{a}$ & 0.838 & 106 & $236 \mathrm{E}+03 \mathrm{U}$ & U \\
\hline SDEE001036 & w & Bromide & ug/g & None & None & 99.9 & $<312$ & $<1.27 E+03$ & $<1.26 \mathrm{E}+03$ & $n / a$ & 0.834 & 101 & $1.27 \mathrm{E}+03 \mathrm{U}$ & U \\
\hline SO6E001036 & $w$ & Chloride & gو & None & None & 106 & $<0.850$ & $2.17 E+03$ & $1.25 \mathrm{E}+03$ & $1.71 E+03$ & 54.2 & 98.9 & 173 & c \\
\hline SO6E001036 & w & Fluoride & ug/g & None & None & 101 & $<30.0$ & $<122$ & $<121$ & $\mathrm{n} / \mathrm{a}$ & 0.838 & 103 & $122] 1$ & U \\
\hline$S 06 E 001036$ & $w$ & Formate & ug/g & None & None & 104 & $<11,6$ & $<2.36 E+03$ & $2.34 E+03$ & $\mathrm{n} / \mathrm{a}$ & 0.838 & 107 & $2.36 \mathrm{E}+03 \mathrm{~L}$ & 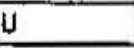 \\
\hline SO6E001036 & w & Glycolale & ug/g & None & None & 99.2 & $<478$ & $<1.95 \mathrm{E}+03$ & $<1.93 E+03$ & $\mathrm{n} / \mathrm{a}$ & 0.836 & 105 & $1.95 E+03$ & U \\
\hline SO6E001036 & w & Niturite & ug/g & None & None & 102 & $<5.40$ & $<1.10 \mathrm{E}+03$ & $<1.09 E+03$ & $\mathrm{n} / \mathrm{a}$ & 0.835 & 103 & $1.10 E+03]$ & $U$ \\
\hline SO6E001036 & w & Oxalate & ug/g & None | & None & 98.5 & $<5.25$ & $<1.07 E+03$ & $<1.06 E+03$ & $\mathrm{Na}$ & 0.832 & 100 & $1.07 \mathrm{E}+03$ & $\mathrm{U}$ \\
\hline S06E001036 & w & Phosphate & lugfg & None [ & None & 102 & $<302$ & $<1.23 \mathrm{E}+\mathrm{D} 3$ & $<1.22 E+03$ & $\mathrm{n} / \mathrm{a}$ & 0.839 & 103 & $123 \mathrm{E}+033 \mathrm{C}$ & $\mathrm{U}$ \\
\hline
\end{tabular}

\section{Enimit Xiolated}


DSR - 20060609

TO2AZ TRAIN

\section{Sample Group: 20060609}

Core Number: 20060609

Sample Portion: Special Sample (Total)

Customer Sample ID: 702-AZ-1 WATER

\begin{tabular}{|c|c|c|c|c|c|c|c|c|c|c|c|c|c|c|}
\hline & & & & Control & & & & & & & & & & \\
\hline Samples $\mathbf{R}$ & A* & Analyte & Unit & Lower & Upper & standard $\%$ & Blank & Rosult & Dupllcate & Average & RPD $x$ & Spk Reec $x$ & Det Limin & Daral flags: \\
\hline $06 E 001036$ & $\bar{w}$ & Sulfate & ug/9 & None & None & 102 & $<6.90$ & $<1.41 E+03$ & $<1.40 E+03$ & n/a & $0.83 a$ & 106 & $1.41 E+03$ & \\
\hline
\end{tabular}

Customer Sample ID: 702-AZ-2

\begin{tabular}{|c|c|c|c|c|c|c|c|c|c|c|c|c|c|c|}
\hline \multirow{2}{*}{\begin{tabular}{|l|} 
Sample* $\quad \mathbf{R}$ \\
\end{tabular}} & \multirow[b]{2}{*}{ All } & \multirow[b]{2}{*}{ Analyto } & \multirow[b]{2}{*}{ Unit } & \multicolumn{2}{|c|}{ Control Limits } & \multirow[b]{2}{*}{ Standand $\%$} & \multirow[b]{2}{*}{ Blank } & \multirow[b]{2}{*}{ Result } & \multirow[b]{2}{*}{ Duplicate } & \multirow[b]{2}{*}{ Average } & \multirow[b]{2}{*}{ RPD * } & \multirow[b]{2}{*}{ SpkRec $\%$} & \multirow[b]{2}{*}{ Det Limit } & \multirow[b]{2}{*}{ Quai Flags } \\
\hline & & & & Lower & Uppet & & & & & & & & & \\
\hline SO6E001026 & & Actinium-228 & uCivg & None & None & $\mathrm{N} / \mathrm{a}$ & $<7.74 E-05$ & $<2.50 \mathrm{E}-04$ & $\mathrm{n} / \mathbf{a}$ & $\mathrm{n} / \mathrm{a}$ & $\mathrm{n} / \mathrm{a}$ & ก/目 & $2.50 E-0.4] \mathrm{U}$ & $\mathbf{u}$ \\
\hline S06E001026 & & Ahuminum-28 & uCing & None & None & $\mathrm{Na}$ & $<8.10 E-04$ & $<2.51 \mathrm{E}-03$ & $\mathrm{n} / \mathrm{a}$ & $\mathrm{N} / \mathrm{a}$ & $\mathrm{n} / \mathrm{a}$ & $\mathrm{r} / \mathrm{a}$ & 2.51E-03 & $\mathbf{U}$ \\
\hline SOEEO01026 & & Americium-24t & uCigg & Nane & None & $\mathrm{Na}$ & $<1.95 E-05$ & $<3.84 E-04$ & $\mathrm{n} / \mathrm{a}$ & nja & $\mathrm{n} / \mathrm{a}$ & $\mathrm{Na}$ & $3.84 \mathrm{E}-04 \mathrm{~L}$ & $U$ \\
\hline SOBEC01026 & & Americium-243 - & uCivg & None & None & $\mathrm{n} / \mathrm{a}$ & $<1.32 E-05$ & $<3.32 \mathrm{E}-04$ & n/a & $\mathrm{n} / \mathrm{a}$ & $n / 9$ & $\mathrm{Na}$ & $3.32 E-04$ & $U$ \\
\hline SO6E001026 & & Antinomy-124 & uCigg & Nane & None & $n / a$ & $<1.55 \mathrm{E}-05$ & $<2.88 E-04$ & $n / a$ & n/a & $\mathrm{n} / \mathrm{a}$ & n/a & $2.88 \mathrm{E}-04 \mathrm{C}$ & U \\
\hline SO6EOD1026 & & Antimony-125 & uCing & Nane & None: & $\mathrm{n} / \mathrm{a}$ & $\angle 4.06 \mathrm{E}-05$ & $<1.83 E-03$ & $\mathrm{Na}$ & $\mathrm{na}$ & $\mathrm{n} / \mathrm{a}$ & $n / a$ a & 1.83E-03 & $\bar{U}$ \\
\hline S08E001026 & & Antimony-126 & ucing & Nane & None & n/a & $<1.74 \mathrm{E}-05$ & $<1.03 E-04$ & $n / a$ & nala & $n / 6$ & n/a & $1.03 \mathrm{E}-04 \mathrm{U}$ & $U$ \\
\hline SO6E001028 & & Argon-41. & uCi/g & None & None & $\mathrm{n} / \mathrm{a}$ & $<3.46 E-05$ & $\angle 1.14 E-04$ & $\mathrm{n} / \mathrm{a}$ & n/a & $\mathrm{n} / \mathrm{a}$ & naa & $1.14 \mathrm{E}-04 \mathrm{U}$ & $\mathrm{U}$ \\
\hline SO6E001026 & & Barkum-133 & ucivg & None & None & n/a & $<1.72 \mathrm{E}-05$ & $\leq 6.80 \mathrm{E}-04$ & $\mathrm{n} / \mathrm{a}$ & n/a & $\mathrm{n} / \mathrm{a}$ & nda & 6.80E-04 & $\mathrm{U}$ \\
\hline SO6EO01026 & & Barhum-140 & uCl/g & None & None & $\mathrm{n} / \mathrm{a}$ & $<5.60 \mathrm{E}-05$ & $<1.55 \mathrm{E}-03$ & $\mathrm{n} / \mathrm{a}$ & $\mathrm{n} / \mathrm{a}$ & $n / a$ & $\mathrm{n} / \mathrm{a}$ & $1.55 \mathrm{E}-03 \mathrm{U}$ & $\bar{U}$ \\
\hline S06E001026 & & Beryllium-7 & uCvg & None & None & $\mathrm{n} / \mathrm{a}$ & $<1.03 E-04$ & $<5.62 \mathrm{E}-03$ & $\mathrm{n} / \mathrm{a}$ & $\mathrm{n} / \mathrm{a}$ & $\mathrm{N} / \mathrm{a}$ & $\pi / \mathrm{a}$ & $5.62 E-03$ & $\mathrm{U}$ \\
\hline SO6E001026 & & Blsmuth-207 & uCirg & None & None & $n / a)$ & $<2.51 \mathrm{E}-05$ & $<8.87 \mathrm{E}-05$ & n/a & na & $\mathrm{n} / \mathrm{a}$ & $\mathrm{n} / \mathrm{a}$ & B. $87 E-05$ & U \\
\hline S06E001026 & & Blsmuth-212 & uCl/g & None & None & $\mathrm{n} / \mathrm{a}$ & $<1,46 \mathrm{E}-04$ & $<6.12 \mathrm{E}-04$ & $\mathrm{n} / \mathrm{a}$ & $\mathrm{n} / \mathrm{a}$ & n/a & $n / 2$ & $5.12 \mathrm{E}-04 \mathrm{U}$ & $\dot{U}$ \\
\hline S06E001026 & & Bismuth-214 & witirg & None & None & $n / a$ & $<3.73 E-05$ & $\angle 5.99 E-04$ & $n / a$ & $\mathrm{Na}$ & $n / a$ & n/a & 5.99E-04 & $\mathrm{U}$ \\
\hline SO6E001026 & & Cadmium-109 & uCi/g & None & None & $\mathrm{n} / \mathrm{a}$ & $<1.43 \mathrm{E}-04$ & $\angle 3.48 E-03$ & n/a & $\mathrm{N} / \mathrm{a}$ & nda & $\mathrm{N} / \mathrm{a}$ & $3.48 \mathrm{E}-03 \mathrm{U}$ & U \\
\hline SO6E001026 & & Cerium-139 & uCis/g & None & None & $n / 2$ & $<9.01 E-06$ & Q.60E-04 & $\mathrm{Na}$ & $\mathrm{n} / \mathrm{a}$ & $n f a$ & n'a & $2.80 \mathrm{E}-04 \mathrm{U}$ & $\mathbf{u}$ \\
\hline SO6E001026 & & Cerium-141 & $u C \mathrm{Ci} / g$ & None & None & $n / 6$ & $<1.23 \mathrm{E}-0.5$ & $<3.34 \mathrm{E}-04$ & $n / \mathrm{a}$ & $n / a$ & $n / a$ & n/a & $3.34 \mathrm{E}-04 \mathrm{U}$ & $\mathbf{u}$ \\
\hline SO6E001026 & & Cerium-144 & $\mathrm{uCv}_{\mathrm{g}}$ & None & None & $n / a$ & $<5.14 E-05$ & $<1,40 E-03$ & $\mathrm{Na}$ & $n / a$ & $\mathrm{n} / \mathrm{a}$ & nia & $1.40 E-03 / 2$ & $\mathbf{U}$ \\
\hline SO6E001026 & & Cerium/Praseodymium-144 & $\mathrm{uCu}_{\mathrm{g}}$ & None & None & $\pi / \mathrm{s}$ & $<1.03 E-04$ & $\angle 2.81 \mathrm{E}-03$ & Na & $n / a$ & n/a & nua & 2.81E-03 & $\mathbf{u}$ \\
\hline SO6ED01026 & & Cesium-134 & $\mathrm{uCl} / \mathrm{g}$ & None & None & $\mathrm{n} / \mathrm{a}$ & $<1.63 \mathrm{E}-0.5$ & $<2.87 \mathrm{E}-04$ & $n / a$ & $\mathrm{n} / \mathrm{a}$ & $\mathrm{n} / \mathrm{a}$ & n/a & 2.87E-OA U & 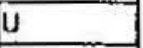 \\
\hline SO6ECO1026 & & Cesium-136 & uCv/g & None & None & $n / a$ & $<1.73 \mathrm{E}-05$ & $<6.37 \mathrm{E}-05$ & $n / 2$ & $\mathrm{n} / \mathrm{a}$ & $n / a$ & $\mathrm{n} / \mathrm{a}$ & 6.37E-05 & $\mathrm{u}$ \\
\hline SO6ED01026 & & Cesium-137 & ucing & None & None & 99.1 & $<1.81 E-05$ & 0.638 & $n / a$ & $\mathrm{n} / \mathrm{a}$ & $\mathrm{n} / \mathrm{a}$ & nia & $5.65 \mathrm{E}-04$ & \\
\hline S06E001026 & & Caslum-138 & $\mathrm{uCi} / \mathrm{g}$ & None & Nane & $n / a$ & $<8.50 \mathrm{E}-0.5$ & $<2.26 E-04$ & $n / a$ & $\mathrm{n} / \mathrm{a}$ & $n / 2$ & nia & $2.26 \mathrm{E}-04 \mathrm{U}$ & $\mathrm{U}$ \\
\hline
\end{tabular}

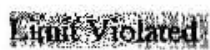


DSR - 20060609

TO2AZ TRAIN

Sample Group: 20060609

Core Number: 20060609

Sample Portion: Special Sample (Total)

Customer Sample ID: 702-AZ-2

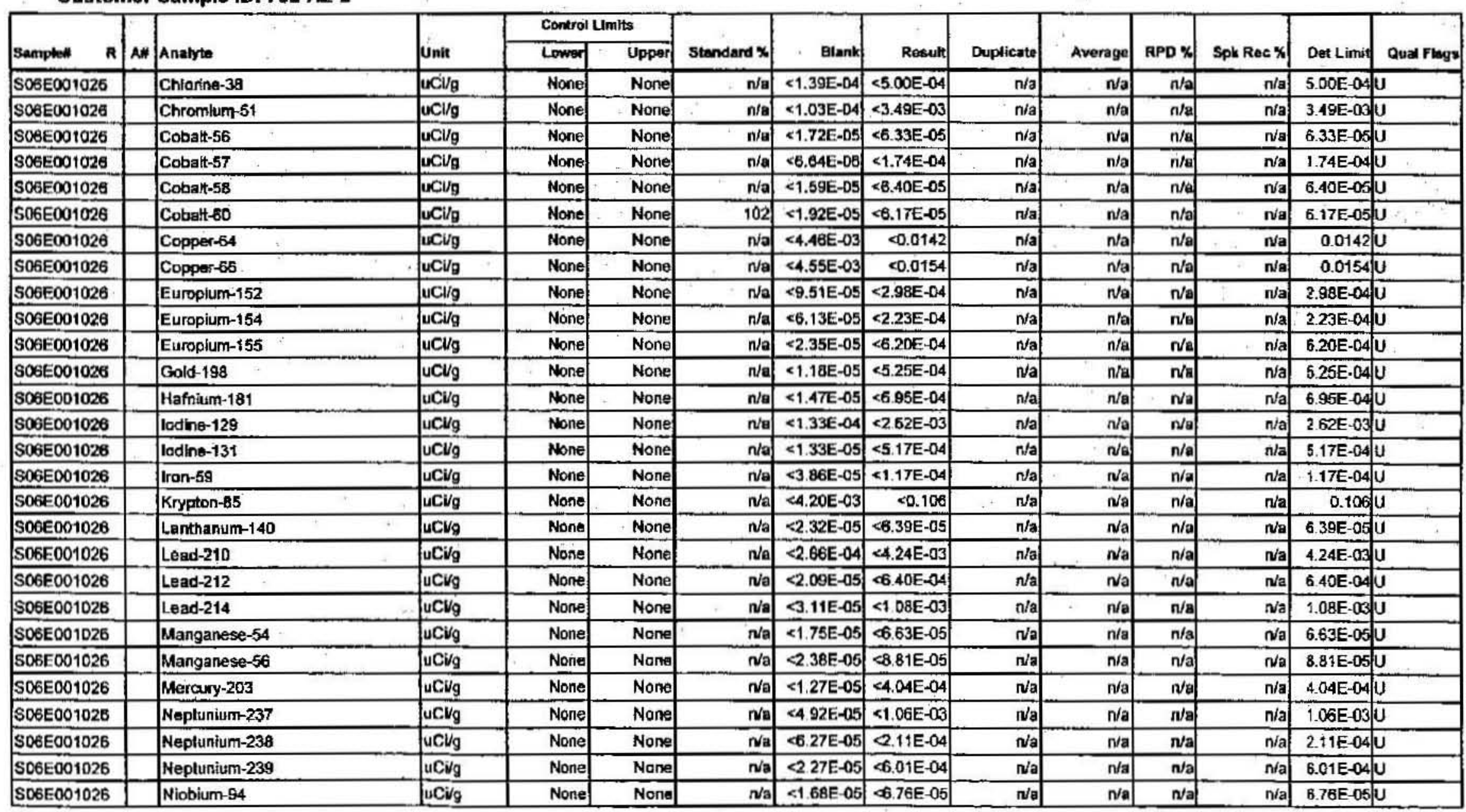

Bimilorotated 
DSR - 20060609

T02AZ TRAIN

\section{Sample Group: 20060609}

Core Number: 20060609

Sample Portion: Special Sample (Total)

Customer Sample ID: 702-AZ-2

\begin{tabular}{|c|c|c|c|c|c|c|c|c|c|c|c|c|c|c|c|}
\hline \multirow[b]{2}{*}{ Samples $\mathbf{R}$} & \multirow[b]{2}{*}{ At: } & \multirow[b]{2}{*}{ Analyle } & \multirow[b]{2}{*}{. } & \multirow[b]{2}{*}{ |Unit } & \multicolumn{2}{|c|}{ Control Limits } & \multirow[b]{2}{*}{ standard $\%$} & \multirow[b]{2}{*}{ Blank } & \multirow[b]{2}{*}{ Result } & \multirow[b]{2}{*}{ Duplicate } & \multirow[b]{2}{*}{ Average } & \multirow[b]{2}{*}{ RPD \% } & \multirow[b]{2}{*}{ Spk Rec $*$} & \multirow[b]{2}{*}{ Det Lirning } & \multirow[b]{2}{*}{ Qual Flags } \\
\hline & & & & & Lower & Upper & & & & & & & & & \\
\hline SDEE001026 & & Plutonium-239 & & uCitg & None & None & $\mathrm{n} / \mathrm{a}$ & $\$ 0.0900$ & $<2.46$ & $\mathrm{n} / \mathrm{a}$ & $n / a$ & nta & $\mathrm{n} / \mathrm{s}$ & $2.46 \mathrm{U}$ & U \\
\hline SO5E001026 & & Polassium-40 & & ucidg & None & None & $\mathrm{n} / \mathrm{a}$ & $<4.56 \mathrm{E}-04$ & $<1.48 \mathrm{E}-03$ & $\mathrm{Na}$ & nia & $\mathrm{n} / \mathrm{\theta}$ & $\mathrm{n} / \mathrm{a}$ & $1.48 \mathrm{E}-03 \mathrm{U}$ & u \\
\hline SO6E001026 & & Protactinium-233 & & uCug & None, & None & $n / a$ & $<2.55 E-05$ & $<8.69 E-04$ & $\mathrm{n} / \mathrm{a}$ & n/a & na & $\mathrm{n} / \mathrm{a}$ & $8.69 \mathrm{E}-04 \mathrm{U}$ & $\vec{u}$ \\
\hline SO6E001026 & & Protactinium-234 & & urCivg & None & None & $\mathrm{n} / \mathrm{a}$ & $<3.09 E-03$ & $<0.0104$ & Na & $n / a$ & $\mathrm{n} / \mathrm{a}$ & $n / a$ & $0.0104 / \mathrm{U}$ & u \\
\hline SO6E001028 & & Radium-224. & & uCug. & None & None & $n^{\prime} / \mathrm{a}$ & $2.45 E-04$ & $<7.30 \mathrm{E}-03$ & $\mathrm{n} / \mathrm{\theta}$ & $\mathrm{Na}$ & $n / a$ & n/a & $7.30 \mathrm{E}-03 \mathrm{U}$ & U \\
\hline SO6EOO1026 & & Radium-226 & & uCing & None & None & $\mathrm{N} / \mathrm{a}$ & $<2.72 E-04$ & $<7.84 \mathrm{E}-03$ & $\mathrm{n} / \mathrm{a}$ & $\mathrm{na}$ & $\mathrm{N} / \mathrm{a}$ & $\mathrm{n} / \mathrm{a}$ & 7.84E-03 U & $\mathbf{U}$ \\
\hline S06E001026 & & Rubidium/Rhodlum-106 & & ucing & None & None & n/日 & $<3.04 E-04$ & $<5.43 E-03$ & $\mathrm{~N} / \mathrm{a}$ & nda & n/a & $\mathrm{N} / \mathrm{a}$ & 5.43E-03) & $U$ \\
\hline SO6E001026 & & Ruthenium-103 & & uCitg & None & None & $\mathrm{n} / \mathrm{\theta}$ & $<1.48 E-05$ & $<5.50 \mathrm{E}-04$ & n/a & n/a & $n / a$ & $n / 2$ & $5.50 E-04] \mathrm{U}$ & U \\
\hline SO6E001026 & & Scendhum-46 & & ucing & None & None & Na & $<2.29 E-05$ & $<7.89 \mathrm{E}-05$ & $\mathrm{n} / \mathrm{a}$ & n/a & n/a & $n / a$ & $7.89 \mathrm{E}-05$ & $\bar{U}$ \\
\hline S06E001026 & & Selenium- 75 & & uCi/g & None & None & $\mathrm{NB}_{\mathrm{B}}$ & $<1.63 \mathrm{E}-05$ & <.0TE-04 & $\mathrm{n} / \mathrm{a}$ & $\mathrm{n} / \mathrm{a}$ & $\mathrm{n} / \mathrm{B}$ & $\mathrm{n} / \mathrm{a}$ & 5.07E-04 & $\overline{\mathbf{U}}$ \\
\hline SO6E000t026 & & Selonium-79 & & uCi $i_{g}$ & None & None & Na & $<1.33 \mathrm{E}-03$ & $<0.0366$ & nia & $\mathrm{Na}$ & $\pi / a$ & $\mathrm{n} / \mathrm{a}$ & 0.0366 & U \\
\hline S06E001026. & & Silver-108 & & $\mathrm{uCv} / \mathrm{g}$ & None & None & $\mathrm{n} / \mathrm{a}$ & $<1.81 E-05$ & $<8.11 E-05$ & $n i a$ & $\mathrm{n} / \mathrm{a}$ & n/a & nia & 8.11E-05 & $U$ \\
\hline SOGE,001026 & & Silver-110 & & $u C v_{g}$ & None & None & $n / a$ & $\leq 1.65 \mathrm{E}-05$ & $<3.24 \mathrm{E}-03$ & $\mathrm{n} / \mathrm{a}$ & $\mathrm{n} / \mathrm{a}$ & $\mathrm{N} / \mathrm{a}$ & nia & 3.24E-03 & U \\
\hline SO6E001026 & & Sodium-22 & & uCi/g & None & None & $\mathrm{n} / \mathrm{a}$ & $<2.11 E-05$ & $<7.67 \mathrm{E}-05$ & $\mathrm{n} / \mathrm{a}$ & $\mathrm{n} / \mathrm{a}$ & $n / \mathrm{a}$ & n/a & $7.67 \mathrm{E}-0.5$ & $\bar{U}$ \\
\hline S06E 001026 & & Sodlum-24 & & $\mathrm{uCV}_{\mathrm{g}}$ & None & None & $n / a$ & $<2.08 E-05$ & $<6.85 \mathrm{E}-05$ & $\mathrm{n} / \mathrm{a}$ & $\mathrm{n} / \mathrm{a}$ & $n / a$ & n/a & 6.85E-05 & $u$ \\
\hline SOGEO01026 & & Strontium-85 & & $u_{C} V_{9}$ & None & None & $\mathrm{n} / \mathrm{a}$ & $<1.82 E-05$ & $<4.58 \mathrm{E}-04$ & $\mathrm{n} / \mathrm{a}$ & nta & $\mathrm{n} / \mathrm{a}$ & $\mathrm{n} / \mathrm{a}$ & $4.58 E-04 \mathrm{U}$ & $U$ \\
\hline S06E001026 & & Tantalum-182 & & ucilg & None & None & $n / a$ & $<6.33 \mathrm{E}-05$ & $\angle 2.23 E-04$ & $\mathrm{n} / \mathrm{a}$ & $\mathrm{n} / \mathrm{a}$ & $\mathrm{n} / \mathrm{a}$ & $\mathrm{n} / \mathrm{a}$ & $2.23 \mathrm{E}-04 \mathrm{U}$ & U \\
\hline S06E001026 & & Tellurium-123 & & ucing & None & None & $\mathrm{n} / \mathrm{a}$ & $<9.11 E-06$ & $<2.42 \mathrm{E}-04$ & $\mathrm{na}$ & n'目 & $\mathrm{n} / \mathrm{a}$ & nfa & 2.42E-04 L & $U$ \\
\hline S06E001026 & & Tellurium-125 & & uCCi/g & None & None & $\mathrm{n} / \mathrm{a}$ & $<1.72 E-05$ & $<6.79 E-04$ & $\mathrm{Na}$ & n/a & $\mathrm{n} / \mathrm{a}$ & $\mathrm{n} / \mathrm{a}$ & $6.79 \mathrm{E}-0.04 \mathrm{~L}$ & $U$ \\
\hline S06E001026 & & Thallium-208 & + & uCvg & None & Nane & $n / a$ & $<1.97 \mathrm{E}-05$ & $<3.58 \mathrm{E}-04$ & $\mathrm{n} / \mathrm{a}$ & $\mathrm{n} / \mathrm{a}$ & $n / a$ & $\mathrm{~N} / \mathrm{a}$ & $3.58 \mathrm{E}-04 \mathrm{U}$ & U \\
\hline S06E001026 & & Thorium-228 & - & ưCing & None & None & $\mathrm{n} / \mathrm{a}$ & $<4.64 E-04$ & $<0.0103$ & $\mathrm{n} / \mathrm{a}$ & NG & $\mathrm{Na}$ & $\mathrm{n} / \mathrm{a}$ & 0.01034 & U \\
\hline S06E001026 & & Thorium-229 & . & uCvig & None & None & $\mathrm{Na}$ & $\angle 4.42 \mathrm{E}-05$ & $<1.18 E-03$ & $\mathrm{n} / \mathrm{a}$ & $\mathrm{n} / \mathrm{a}$ & $\mathrm{nda}$ & $\mathrm{n} / \mathrm{a}$ & $1.18 \mathrm{E}-03 \mathrm{~L}$ & $U$ \\
\hline S06E001026 & & Thorium-234 & & $u C v_{g}$ & None & None & $\mathrm{n} / \mathrm{a}$ & $<1,85 \mathrm{E}-0 \mathrm{Q}$ & $<3.55 \mathrm{E}-03$ & $\mathrm{n} / \mathrm{a}$ & $n / \mathrm{a}$ & $\mathrm{n} / \mathrm{a}$ & $\mathrm{n} / \mathrm{a}$ & 3.56E-03 & u \\
\hline S06EC01026 & & $\pi n-113$ & & uCvg & None & Mone & $\mathrm{n} / \mathrm{a}$ & $\angle 1.67 \mathrm{E}-05$ & $<7.03 E-04$ & $\mathrm{Na}$ & nia & $\mathrm{n} / \mathrm{a}$ & $\mathrm{n} / \mathrm{a}$ & 7.03E-04 U & $\mathbf{u}$ \\
\hline SOBE001026 & & Tin-126 & & uCvg & None & None & $\mathrm{n} / \mathrm{a}$ & $<1,19 \mathrm{E}-05$ & $<2.82 \mathrm{E}-04$ & $\mathrm{n} / \mathrm{a}$ & $\mathrm{N} / \mathrm{a}$ & $\mathrm{n} / \mathrm{a}$ & $n / \theta$ & 2.82E-04 U & U \\
\hline SO6E001026 & & Uranium-232 & & uCivg & Nane & Nane & $n / a$ & $<3.74 \mathrm{E}-03$ & $<.0701$ & $\mathrm{n} / \mathrm{a}$ & $\mathrm{n} / \mathrm{a}$ & $n / a$ & $\mathrm{n} / \mathrm{a}$ & 0.0701 & $\mathbf{U}$ \\
\hline S06E001026 & & Uranium-235 & & uCvg & None & None & $\mathrm{n} / \mathrm{a}$ & $<1.67 \mathrm{E} .05$ & $\angle 4.73 E-04$ & $\mathrm{n} / \mathrm{a}$ & $\mathrm{n} / \mathrm{a}$ & $n / a$ & $\mathrm{n} / \mathrm{a}$ & $4.73 \mathrm{E}-04 \mathrm{C}$ & $\mathbf{U}$ \\
\hline S06E001028 & & Uranium-237 & & $\mathrm{uCV} g$ & None & None & $\mathrm{a} / \mathrm{a}$ & $<1.92 E-05$ & $<5.27 \mathrm{E}-04$ & $\mathrm{~N} / \mathrm{a}$ & $\mathrm{n} / \mathrm{a}$ & $\mathrm{n} / \mathrm{a}$ & $\mathrm{n} / \mathrm{a}$ & 5.27E- $-04 \mathrm{~L}$ & U \\
\hline
\end{tabular}

finition 
RPP-RPT-31293, Rev. 0

$\frac{N}{\mathfrak{8}}$
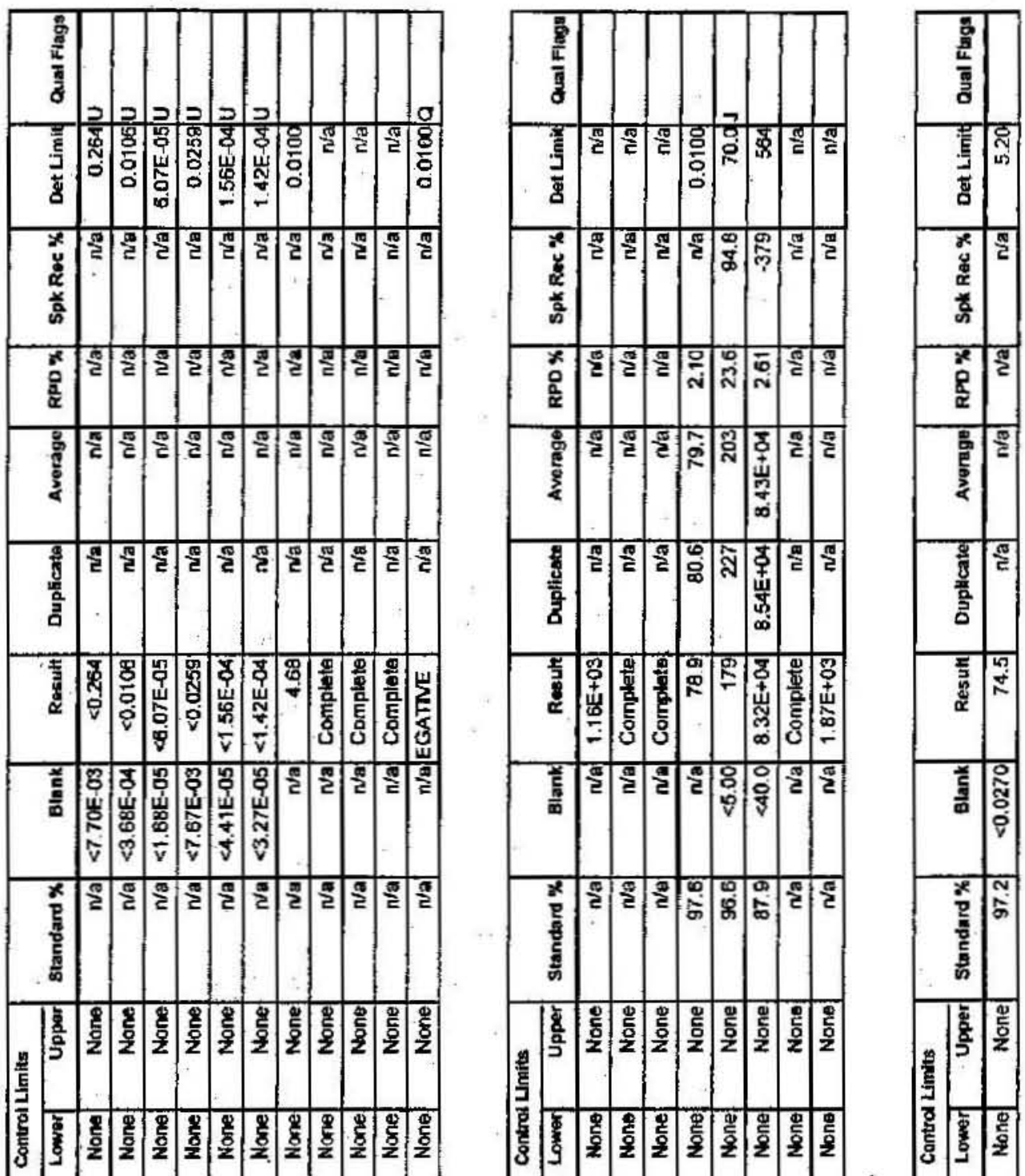

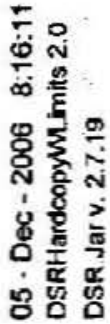

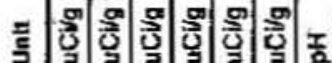

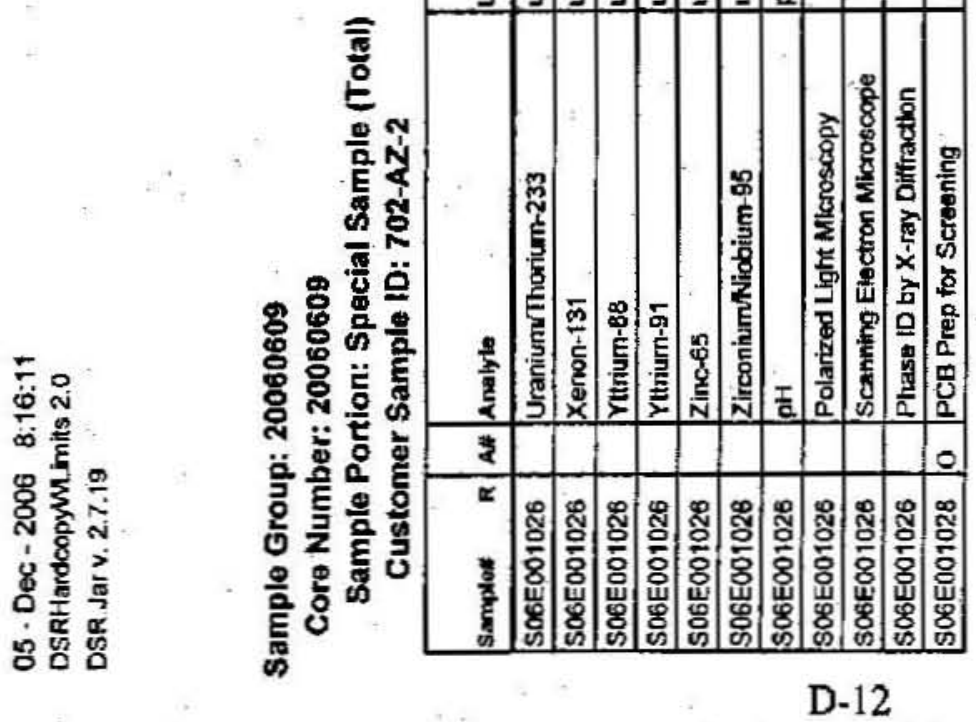

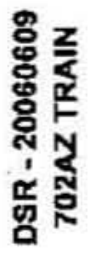
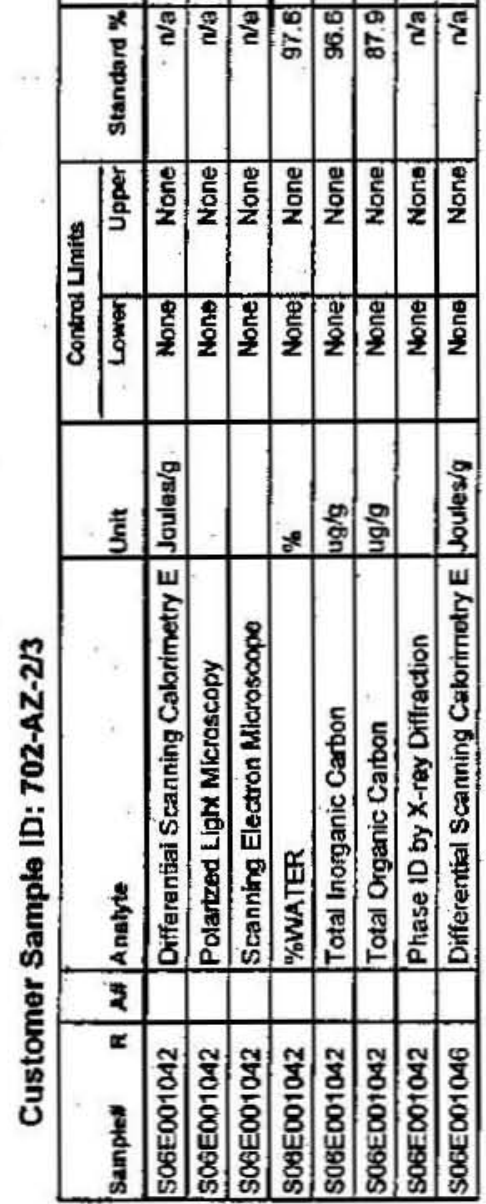

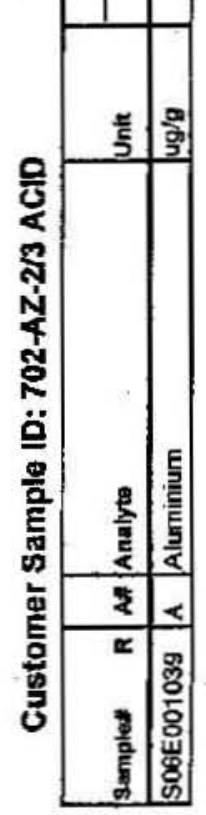

D-12 
DSR - 20060609

TO2AZ TRAIN

\section{Sample Group: 20060609}

Core Number: 20060609

\section{Sample Portion: Special Sample (Total)}

\section{Customer Sample ID: 702-AZ-2/3 ACID}

\begin{tabular}{|c|c|c|c|c|c|c|c|c|c|c|c|c|c|c|c|c|}
\hline \multirow[b]{2}{*}{ Sample\# $\mathbf{R}$} & \multirow[b]{2}{*}{ Aa } & \multirow[b]{2}{*}{ Analyto } & & \multirow{2}{*}{$\because$} & \multirow[b]{2}{*}{ Unik } & \multicolumn{2}{|c|}{ Control Limits } & \multirow[b]{2}{*}{ Standard \% } & \multirow[b]{2}{*}{ Blank } & \multirow[b]{2}{*}{ Resule } & \multirow[b]{2}{*}{ Duplicato } & \multirow[b]{2}{*}{ Averago } & \multirow[b]{2}{*}{ RPD $\%$} & \multirow[b]{2}{*}{ Spk floc $\%$} & \multirow{2}{*}{ Det Limit } & \multirow[b]{2}{*}{ Quad flags } \\
\hline & & & & & & Lower & Upper & & & & & & & & & \\
\hline SO6E001039 & $\mathrm{A}$ & Antimony & & . & ugg/g & None & None & 92.9 & $<0.0280$ & $<5.40$ & $\mathrm{Na}$ & $\mathrm{n} / \mathrm{a}$ & $\mathrm{n} / \mathrm{a}$ & $\mathrm{Na}$ & 5.39 & U \\
\hline SO6E001039 & A & Arsenic: & & & $\log / 9$ & None & None & 103. & $<0.0590$ & $<11.4$ & $\mathrm{n} / \mathrm{a}$ & $\mathrm{n} / \mathrm{a}$ & $\mathrm{n} / \mathrm{a}$ & $\mathrm{n} / \mathrm{a}$ & $11.4 \mathrm{I}$ & $\mathrm{U}$ \\
\hline SOSE001039 & $A$ & Banium & & & uog/g & None, & None & 96.6 & $<7.00 \mathrm{E}-03$ & 15.8 & $\mathrm{n} / \mathrm{a}$ & $n / a$ & $n / a$ & $n / 2$ & 1.35 & \\
\hline SO6E001039 & $\mathrm{A}$ & Beryllium & & \pm & ug/g & None & None & 104 & $<1.20 \mathrm{E}-0.3$ & $<0.231$ & $\mathrm{n} / \mathrm{a}$ & $n / a$ & nia & $\mathrm{n} / \mathrm{a}$ & $0.231 \mid$ & U \\
\hline SO6E001039 & $A$ & Bismuth & & 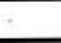 & ugg/g. & None, & None & 90.1 & $<0.102$ & $<19.7$ & $\mathrm{n}+\mathrm{a}$ & $n / a$ & $\mathrm{n} / \mathrm{a}$ & $\mathrm{n} / \mathrm{a}$ & 19.7 & $\mathbf{U}$ \\
\hline S06E001039 & A & Boron & & & ug $/ 9$ & None & None & 92.1 & $<0.0180$ & $1.22 \mathrm{E}+03$ & $\mathrm{n} / \mathrm{a}$ & $\mathrm{n} / \mathrm{a}$ & $\mathrm{n} / \mathrm{a}$ & $\mathrm{n} / \mathrm{a}$ & 3.47 & \\
\hline SO6E001039 & $A$ & Cadmium & & & ug $/ 9$ & None & None & 92.9 & $\angle .00 E-03$ & $<0.578$ & $n / a$ & n'a & $\mathrm{n} / \mathrm{a}$ & $n / a$ & 0.578 & $\mathrm{u}$ \\
\hline SD6E001039 & A & Calcium & & & ug/g & None & None & 116 & $<0.0800$ & $5.10 \mathrm{E}+03$ & $\mathrm{n} / \mathrm{a}$ & $\mathrm{n} / \mathrm{a}$ & n/a & $n / a$ & 15.4 & \\
\hline SO6E001039 & A & Cenum & & & ug/g & None & None & 96.1 & $<0.0150$ & $<2.89$ & $n / a$ & n'a & nfa & $n / a$ & 2.890 & U \\
\hline SO6EOO1039 & $A$ & Chromiurn & & & ugg/9 & None & None & 96.5 & $<0.0140$ & 4.82 & n/日 & n/a & $\mathrm{n} / \mathrm{a}$ & $\mathrm{Na}$ & $2.70 \mathrm{~J}$ & 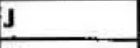 \\
\hline $506 \mathrm{E} 001039$ & A & Cobait & & & ugis & None & None & 94.2 & $<8.00 \mathrm{E}-03$ & $<1.54$ & $\mathrm{n} / \mathrm{a}$ & $\mathrm{n} / \mathrm{a}$ & n/a & $\mathrm{N} / \mathrm{a}$ & $1.54 \mathrm{~L}$ & $\mathbf{u}$ \\
\hline S06EO01039. & $A$ & Copper & & & ug/g & None & None & 94.7 & $<0.014 a$ & 31.2 & $\mathrm{n} / \mathrm{a}$ & $\mathrm{N} a$ & nta & n/a & 2.70 & \\
\hline SO6E001039 & $A$ & Europium & & & Jugh & None & None & 94.8 & $<1.00 E-03$ & 1.14 & $\mathrm{n} / \mathrm{e}$ & nia & $\mathrm{n} / \mathrm{a}$ & $\mathrm{n} / \mathrm{a}$ & 0.193 & 3 \\
\hline S06E001039 & $A$ & Iron & & & ug/g & None & None & 94.6 & $<0.0130$ & 995 & $\mathrm{n} / \mathrm{a}$ & $\mathrm{n} / \mathrm{a}$ & $\mathrm{n} / \mathrm{a}$ & $\mathrm{n} / \mathrm{a}$ & 2.50 & \\
\hline S06E001039 & $A$ & Lanthainum & & & ug/g & None & None & 95.2 & $<B .00 E-03$ & $<1.54$ & $\mathrm{n} / \mathrm{a}$ & róa & $\mathrm{n} / \mathrm{a}$ & $n / a$ & 1.54 & U \\
\hline S06E001039 & A & Lead & & & ugig. & None & None & 92.7 & $<0.0360$ & 10.4 & n/a & nia & $n / a$ & $\mathrm{n} / \mathrm{a}$ & $6.94 \mathrm{~J}$ & 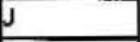 \\
\hline SO6E001039 & A & Lithium & & & ugig & None & None & 98.7 & $<9.00 \mathrm{E}-0 \mathrm{~s}$ & 2.01 & $\mathrm{na}$ & nia & n'a & $\mathrm{n} / \mathrm{a}$ & $1.73 \mathrm{j}$ & 5 \\
\hline SO6EC01038 & $\Lambda$ & Magnesiurn & & & ug/g & None & None & 89.4 & $<0.0150$ & $1.99 \mathrm{E}+03$ & $\mathrm{~N} / \mathrm{a}$ & n/a & $n / a$ & n/a & 2.89 & \\
\hline SOSE001039 & $A$ & Manganese & & & 4.9/g & None & None & 94.5 & $<7.00 E-03$ & 21.3 & $n / a$ & $\mathrm{n} / \mathrm{a}$ & n/目 & $\mathrm{n} / \mathrm{a}$ & 1.35 & \\
\hline SO6E001039 & A & Molybdenum & & & ug $/ \mathrm{g}$ & None & None & 95.2 & $<3.00 \mathrm{E}-03$ & 2.98 & $\mathrm{n} / \mathrm{a}$ & $\mathrm{n} / \mathrm{a}$ & $n / \theta$ & $\mathrm{n} / \mathrm{a}$ & $0.578 \mathrm{~J}$ & J \\
\hline S06E001039 & A & Neodymium & & & ugkg & None & None & 94.1 & $<8.00 E-03$ & $<1.54$ & n/a & $\mathrm{n} / \mathrm{a}$ & $n / a$ & $\mathrm{n} / \mathrm{a}$ & $1.54 \pi$ & $\mathrm{U}$ \\
\hline SO6E001039 & A & Nickel & & & ug/g & None & None & 94.2 & $<0.0220$ & $<4.24$ & $\mathrm{n} / \mathrm{a}$ & $\mathrm{n} / \mathrm{a}$ & $\mathrm{n} / \mathrm{a}$ & $\pi \mathrm{a}$ & $4.24 \mathrm{l}$ & $u$ \\
\hline SO6E001039 & A & Phosphorus & & & ug/g & None & None & 94.7 & $<0.0430$ & 879 & $\mathrm{n} / \mathrm{a}$ & $\mathrm{n} / \mathrm{a}$ & $\mathrm{n} / \mathrm{a}$ & $n / a$ & 8.28 & \\
\hline SO6E001039 & A & Potassium & & : & ug/g & None & None & 99.7 & $<0.295$ & $2.20 \mathrm{E}+03$ & $\mathrm{n} / \mathrm{a}$ & $\mathrm{n} / \mathrm{a}$ & $n / a$ & $\mathrm{n} / \mathrm{a}$ & 56.8 & \\
\hline SO6E001039 & $A$ & Samarium & & & ugg & None & None & 96.0 & $<0.0170$ & $<3.28$ & nia & $\mathrm{n} / \mathrm{a}$ & $\mathrm{n} / \mathrm{a}$ & $\mathrm{n} / \mathrm{a}$ & $3.28 \mathrm{~L}$ & U \\
\hline SO6E001039 & A & Selenium & & $\therefore$ & ug/g & None & None: & 93.8 & $<0.0640$ & $<12.3$ & $\mathrm{n} / \mathrm{a}$ & $\mathrm{n} / \mathrm{a}$ & $n / a$ & $\mathrm{~N} / \mathrm{a}$ & $12.3 \mathrm{u}$ & U \\
\hline SO6E001039 & A & Sillicon & & & ug/g & None, & None & 84.6 & $<0.0460$ & 128 & $n / a$ & $\mathrm{n} / \mathrm{a}$ & $\mathrm{n} / \mathrm{a}$ & $\mathrm{N} / \mathrm{a}$ & 8.86 & \\
\hline SG6EDO1039 & A & Sitwer & & & ug/g & None: & None & 93.3 & $<4.00 E-03$ & $<0.771$ & $\mathrm{n} / \mathrm{a}$ & $\mathrm{n} / \mathrm{a}$ & $n / \mathrm{a}$ & $\mathrm{n} / \mathrm{a}$ & $0.771]_{E}$ & BU \\
\hline
\end{tabular}

\section{Liniflorolated}


Sample Group: 20060609

Core Number: 20060609

Sample Portion: Special Sample (Total)

Customer Sample ID: 702-AZ-2/3 ACID

\begin{tabular}{|c|c|c|c|c|c|c|c|c|c|c|c|c|c|c|c|}
\hline \multirow[b]{2}{*}{ Sumplat $\quad R$} & \multirow[b]{2}{*}{ A\# } & \multirow{2}{*}{ Anatyce } & \multirow[t]{2}{*}{. } & \multirow[b]{2}{*}{ Unit } & \multicolumn{2}{|c|}{ Control Linnits } & \multirow[b]{2}{*}{ Standard $\% /$} & \multirow[b]{2}{*}{ Blank } & \multirow[b]{2}{*}{ Result| } & \multirow[b]{2}{*}{ Duplicate } & \multirow[b]{2}{*}{ Average } & \multirow[b]{2}{*}{ RPD * } & \multirow{2}{*}{ Spk Rec $\%$} & \multirow[b]{2}{*}{ Det Limite } & \multirow{2}{*}{ Qual Flagg } \\
\hline & & & & & Lower & Upper & & & & & & & & & \\
\hline SO6E001039 & $A$ & Sodium & & ug/g & None & None & 96.6 & $<0.0420$ & $3.58 \mathrm{E}+04$ & $n / a$ & $\mathrm{n} / \mathrm{a}$ & $\mathrm{Na}$ & nia & 8.09 & \\
\hline S06E001039 & $\mathrm{A}$ & Strontium. & & ug/g & None & Nons & 96.7 & $\triangle 7.00 E-03$ & 6.58 & n/a & $\mathrm{n} / \mathrm{a}$ & $n / a$ & $\mathrm{n} / \mathrm{a}$ & $1.35 \mathrm{~J}$ & \\
\hline SO6E001039 & $A$ & Sulfur & & ug/g & None & None & 88.7 & $<0.0580$ & 976 & $n / a$ & $n / a$ & $n i a$ & $\mathrm{n} / \mathrm{a}$ & 11.2 & \\
\hline SO6E001039 & A & Thallium & & ug/g. & None & None & 104 & $<0.0560$ & $<10.8$ & $n / a$ & $\mathrm{n} / \mathrm{a}$ & n/a & $\mathrm{n} / \mathrm{a}$ & $10.8 \mathrm{U}$ & $\bar{u}$ \\
\hline SO6E001039 & $A$ & Thorium & t. & ug/g & None & None & 87.2 & $\angle 9.00 E-03$ & 1.80 & na & $n / a$ & $n / a$ & $\mathrm{~N} / \mathrm{a}$ & $1.73 \mathrm{~J}$ & \\
\hline 506E001039 & A & Titanium & & ug/g. & None & None & 95.8 & $<2.00 E-03$ & 8.40 & na & $\mathrm{n} / \mathrm{a}$ & nia & $\mathrm{n} / \mathrm{a}$ & 0.385 & \\
\hline SO6E001039 & $A$ & Uranium & & ug/g & None & None & 92.1 & $<0.0310$ & 10.4 & nia & $\mathrm{n} / \mathrm{s}$ & $\mathrm{n} / \mathrm{s}$ & $\mathrm{n} / \mathrm{a}$ & $5.97 \mathrm{~J}$ & J \\
\hline SO6E001038 & $\mathbf{A}$ & Vanadium & & ug/g & None & None & 96.7 & $<6$ OOE-03 & $<1.16$ & $\mathrm{n} / \mathrm{a}$ & $\mathrm{n}$ /目 & $\mathrm{n} / \mathrm{a}$ & $\mathrm{n} / \mathrm{a}$ & $1.16 \mathrm{U}$ & $\bar{U}$ \\
\hline SO6EDD1039 & $A$ & Yttrium & 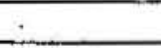 & ug/g & None & None & 94.5 & $<0.0110$ & $<2.12$ & $\mathrm{n} / \mathrm{a}$. & n/a & $n / a$ & $n / a$ & $2.12 \mathrm{U}$ & $\mathrm{U}$ \\
\hline SO6EDD1039 & $A$ & Zinc & & ug/g & None & None & 91.2 & 0.105 & 146 & $\mathrm{n} / \mathrm{a}$ & $\mathrm{n} / \mathrm{a}$ & $\mathrm{n} / \mathrm{a}$ & $\mathrm{n} / \mathrm{a}$ & $0.771 \mathrm{~B}$ & \\
\hline SO6EDD1039 & $A$ & Zirconium & & $\mathrm{ug} / \mathrm{g}$ & None & None & 99.6 & $<2,00 E-03$ & 0.407 & nfa & a & $\mathrm{n} / \mathrm{a}$ & $\mathrm{n} / \mathrm{a}$ & $0.385 \mathrm{~J}$ & \\
\hline
\end{tabular}

Customer Sample ID: 702-AZ-2/3 NH4

\begin{tabular}{|c|c|c|c|c|c|c|c|c|c|c|c|c|c|c|}
\hline \multirow[b]{2}{*}{ Sample $\quad \mathbf{R}$} & \multirow[b]{2}{*}{ All } & \multirow{2}{*}{ Anatyto } & \multirow[b]{2}{*}{ Unit } & \multicolumn{2}{|c|}{ Control Umits } & \multirow[b]{2}{*}{ Standard $\%$} & \multirow[b]{2}{*}{ Blank } & \multirow[b]{2}{*}{ Rosult } & \multirow[b]{2}{*}{ Duplicated } & \multirow[b]{2}{*}{ Average } & \multirow[b]{2}{*}{ RPD \% } & \multirow[b]{2}{*}{ Spk Rec K } & \multirow[b]{2}{*}{. Det Limit } & \multirow[b]{2}{*}{ Qual Flags } \\
\hline & & & & Lower & Upper & & & & & & & & & \\
\hline S06ED0t038 & 5 & Ammonium lon & ug/g & None & None & 102 & $<6.44 E-03$ & $1.48 E+05$ & $1.30 \mathrm{E}+0.5$ & $1.38 E+05$ & 10.9 & n/日 & 0.719 & \\
\hline
\end{tabular}

Customer Sample 10: 702-AZ-2/3 SVOA

\begin{tabular}{|c|c|c|c|c|c|c|c|c|c|c|c|c|c|c|}
\hline \multirow[b]{2}{*}{ Samples R } & \multirow[b]{2}{*}{ A\# } & \multirow{2}{*}{ Analyte } & \multirow[b]{2}{*}{ Unit } & \multicolumn{2}{|c|}{ Control Limitis } & \multirow[b]{2}{*}{ standard \% } & \multirow[b]{2}{*}{ Blenk } & \multirow[b]{2}{*}{ Result } & \multirow[b]{2}{*}{ Duplcate } & \multirow[b]{2}{*}{ Average } & \multirow[b]{2}{*}{ RPD $\%$} & \multirow[b]{2}{*}{ Spk Rec $\%$} & \multirow[b]{2}{*}{ Dat Limit } & \multirow[b]{2}{*}{ qual Flags } \\
\hline & & & & Lower & Upper & & & & & & & & & \\
\hline S06E001041 & & Alpha/Beta Organic Scan & & Nene & None & $\mathrm{n} / \mathrm{a}$ & $n / \mathrm{a}$ & Complete & $\mathrm{n} / \mathrm{a}$ & n/a & $n / \mathrm{a}$ & $n / a$ & $n / a$ & \\
\hline SO6E001041 & $a$ & 1,2,4-Tichlorobenzene & $\operatorname{ug} / \mathrm{K}_{\mathrm{g}}$ & None & None & 74.8 & $<1,62 E+03$ & $<833$ & $\mathrm{n} / \mathrm{a}$ & $n / a$ & $\mathrm{n} / \mathrm{a}$ & n/a & 8330 & U \\
\hline SO6E 001041 & 0 & 1,2-Dichlorobenzene & ug/Kg & None. & Nane & $\mathrm{n} / \mathrm{a}$ & $<2.76 E+03$ & $<1.42 E+03$ & $n / 3$ & nfa & $\mathrm{n} / \mathrm{a}$ & $n / a$ & $142 \mathrm{E}+03 \mathrm{U}$ & $\mathrm{U}$ \\
\hline SDEE001041 & 0 & 1.4-Dichlorobenzene & ug/Kg & None & None & 71.3 & $<1.67 E+03$ & $<858$ & $\mathrm{n} / \mathrm{a}$ & $n / a$ & $\mathrm{n} / \mathrm{a}$ & $n / a$ & $858 \mathrm{U}$ & $\bar{u}$ \\
\hline SD6E001041 & 0 & 2.2'-oxybis(1-Chtoropropane) & ugh $\mathrm{Kg}$ & None & None & $n / a$ & $<1.98 E+03$ & $<1.02 E+03$ & n'a & $\mathrm{n} / \mathrm{a}$ & $\mathrm{n} / \mathrm{a}$ & $n / a$ & $1.02 \mathrm{E}+03 \mathrm{C}$ & $\bar{v}$ \\
\hline SO6E001041 & 0 & 2,4,5-Trichtorophenol & ug/Kg & None: & None & $n / a$ & $<1.56 \mathrm{E}+03$ & $<801$ & $\mathrm{n} / \mathrm{a}$ & $\mathrm{n} / \mathrm{a}$ & $n / a$ & $n / a$ & 8016 & u \\
\hline S08E001041 & $a$ & 2,4,6-Trichlorophanol & ug/Kg & None & None & $\mathrm{n} / \mathrm{a}$ & $<1.62 E+03$ & $<830$ & $\mathrm{n} / \mathrm{a}$ & $\mathrm{n} / \mathrm{a}$ & n/a & $n / a$ & $830 \mathrm{~L}$ & U \\
\hline SOBE001041 & $a$ & 2,4-Dichlorophenol & ug/Kg & None & None & n/a & $<1.51 E+03$ & $<776$ & na & $\mathrm{n} / \mathrm{a}$ & 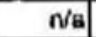 & $n / a$ & 7764 & $\bar{u}$ \\
\hline
\end{tabular}

Lume Kiofated: 


\section{Sample Group: 20060609 \\ Core Number: 20060609 \\ Sample Portion: Special Sample (Total) \\ Customer Sample ID: 702-AZ-2/3 SVOA}

\begin{tabular}{|c|c|c|c|c|c|c|c|c|c|c|c|c|c|c|c|}
\hline \multirow[b]{2}{*}{ Samplea* $\quad R$} & \multirow[b]{2}{*}{ A* } & \multirow[b]{2}{*}{ Analyte } & & \multirow[b]{2}{*}{ Unit } & \multicolumn{2}{|c|}{ Controf Limitts } & \multirow[b]{2}{*}{ Standard $\%$} & \multirow[b]{2}{*}{ Blank } & \multirow[b]{2}{*}{ Result } & \multirow[b]{2}{*}{ Duplicate } & \multirow[b]{2}{*}{ Average } & \multirow[b]{2}{*}{$R P O \%$} & \multirow[b]{2}{*}{ Spk Rec \% } & \multirow[b]{2}{*}{ Det Lirnif } & \multirow[b]{2}{*}{ Qual Flage } \\
\hline & & & & & Lower & Upper & & & & & & & & & \\
\hline SO6ED01041 & o & 2,4-Dimethylphenot & & ug/Kg & None & None & $\mathrm{n} / \mathrm{a}$ & $<118 E+03$ & $<607$ & $n / a$ & $\mathrm{n} / \mathrm{a}$ & $\mathrm{n} / \mathrm{a}$ & n/a & 607 & U \\
\hline SO6ED01041 & o & 2,4-Dinitrophenol & & ug/Kg & None & None & $\mathrm{Na}$ & $<823$ & $\angle 423$ & $n / a$ & $\mathrm{n} / \mathrm{a}$ & $\mathrm{n} / \mathrm{a}$ & na & 4234 & $U$ \\
\hline SO6E001041 & $a$ & 2,4-Dinitrotoluene & & ug $/ \mathrm{Kg}$ & None & None & 97.0 & $<1.79 E+03$ & $<917$ & $n / a$ & $\mathrm{n} / \mathrm{a}$ & $\mathrm{n} / \mathrm{a}$ & nia & 917u & $u$ \\
\hline SO6E.001041 & a & 2,6-Dinitrololuene & & $\mu g / K g$ & None & None & $n / a$ & $<1.72 \mathrm{E}+03$ & -883 & $n / a$ & $\mathrm{n} / \mathrm{a}$ & $17 / \mathrm{a}$ & $\mathrm{n} / \mathrm{a}$ & $883 / 4$ & $\mathbf{u}$ \\
\hline SO6E001041 & 0 & 2-Butoxyethanoi & & $u g / \mathrm{Kg}$ & None & None & $n / a$ & $<3.01 E+04$ & $<1.54 E+04$ & $\mathrm{n} / \mathrm{a}$ & $\mathrm{n} / \mathrm{a}$ & $\mathrm{n} / \mathrm{a}$ & $n / a$ & $1.54 E+04$ & $\mathbf{U}$ \\
\hline SOGE001041 & 0 & 2-Chloronaphthakene & & ug/Kg & None & None & n/a & $<1.64 E+03$ & $<844$ & $\mathrm{~N} / \mathrm{a}$ & $\mathrm{n} / \mathrm{a}$ & $\mathrm{n} / \mathrm{a}$ & $\mathrm{n} / \mathrm{a}$ & $844 \mathrm{~L}$ & $\mathrm{U}$ \\
\hline S06E001041 & 0 & 2-Chtorophenol & & $\log / \mathrm{Kg}$ & None & None & 78.2 & $<1.63 E+03$ & $<939$ & $n / a$ & $\mathrm{n} / \mathrm{a}$ & $\mathrm{n} / \mathrm{a}$ & $\mathrm{rata}$ & 839 & $U$ \\
\hline SO6ED01041 & 0 & 2-Methyinaphthalene & & ughikg & None & None & n/a & $<1.73 E+03$ & $\angle 889$ & $\mathrm{n} / \mathrm{a}$ & $\mathrm{n} / \mathrm{a}$ & $\mathrm{n} / \mathrm{a}$ & $\pi / \mathrm{B}$ & sag L & $U$ \\
\hline S06E001041 & 0 & 2-Methylphenol & & $\operatorname{ug} / \mathrm{Kg}$ & None & None & nia & $<1.70 E+03$ & $<874$ & nda & $\mathrm{n} / \mathrm{a}$ & $\mathrm{n} / \mathrm{a}$ & $n / 8$ & 974 L & $\underline{U}$ \\
\hline S06E001041 & 0 & 2-Nitroaniline & 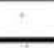 & $\operatorname{lug} / \mathrm{Kg} g$ & None & None & $\mathrm{n} / \mathrm{a}$ & $<1.75 E+03$ & $<800$ & $n / a$ & $n / a$ & $n / a$ & $n / a$ & 900 & $U$ \\
\hline S06E001041 & 0 & 2-Nitrophenol & & ug/ $/ \mathrm{Kg}$ & None & None & ח/'目 & $<1.50 E+03$ & $<77$ & n/a & $\mathrm{N} / \mathrm{a}$ & $n / a$ & $\mathrm{n} / \mathrm{a}$ & 7710 & $u$ \\
\hline S06E001041 & 0 & 384 Mathytphenal Total & & ug/Kg & None & None & n/a & $<1.65 E+03$ & $<846$ & $\mathrm{n} / \mathrm{a}$ & $n / 8$ & $\mathrm{n} / \mathrm{a}$ & Na & 846 i & U \\
\hline S06E001041 & 0 & 3-Nitroaniline & & ugg/Kg & None: & None & n/g & $<987$ & $<507$ & $\mathrm{n} / \mathrm{a}$ & $\mathrm{n} / \mathrm{a}$ & $\mathrm{n} / \mathrm{a}$ & $n / a$ & 5074 & U \\
\hline S06E001041 & 0 & 4,6-Dinitro-2-methylphenol & & ugg/Kg & None & None & $\mathrm{n} / \mathrm{a}$ & $<1.19 E+03$ & 608 & $\mathrm{n} / \mathrm{a}$ & $\mathrm{n} / \mathrm{a}$ & $\mathrm{n} / \mathrm{a}$ & $\mathrm{n} / \mathrm{a}$ & 608 & u \\
\hline S06E001041 & 0 & 4-Bromophenyl-phenylether & & $\log / \mathrm{Kg}$ & None & None & $\mathrm{n} / \mathrm{a}$ & $<1.72 E+03$ & $<884$ & $\mathrm{n} / \mathrm{s}$ & $n / a$ & $\mathrm{n} / \mathrm{a}$ & n/a & 8840 & U \\
\hline SO6E001041 & 0 & 4-Chloro-3-methyiphenol & & $\log / \mathrm{Kg}$ & None & None & 69.1 & $\angle 1.68 E+03$ & $<861$ & $\mathrm{n} / \mathrm{a}$ & $\mathrm{Na}$ & $\mathrm{n} / \mathrm{a}$ & $\mathrm{n} / \mathrm{a}$ & $881]$ & $\bar{u}$ \\
\hline S06E001041 & 0 & 4-Chloroaniline & & ug/Kg & None & None & $\mathrm{n} / \mathrm{a}$ & $<3.45 E+03$ & $<1.77 \mathrm{E}+03$ & nia & $n / a$ & $\mathrm{n} / \mathrm{a}$ & $n / a$ & $1.77 E+03$ & $u$ \\
\hline SO6E001041 & 0 & 4-Chlorophenyl-phenylether & +1 & $\log / \mathrm{Kg}$ & Fone & None & $\mathrm{N} / \mathrm{a}$ & $<1.71 E+03$ & $<879$ & $\mathrm{n} / \mathrm{a}$ & $\mathrm{n} / \mathrm{a}$ & $\mathrm{n} / \mathrm{a}$ & N/田 & 879 & U \\
\hline SO6E001041 & o & 4-Nitroaniline & 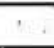 & ug $/ \mathrm{Kg}$ & None & None & $\mathrm{n} / \mathrm{a}$ & $<2.01 E+03$ & $<1.03 E+03$ & $\mathrm{n} / \mathrm{a}$ & $n / \theta$ & $n / a$ & n/a & $1.03 E+03$ & $\mathrm{u}$ \\
\hline S06E001041 & 0 & 4-Nitrophenot & & ug/Kg & None & None & 113 & $\angle 1.59 E+03$ & $<815$ & $\mathrm{n} / \mathrm{a}$ & $\mathrm{n} / \mathrm{a}$ & $\mathrm{n} / \mathrm{a}$ & $n / a$ & 815 & $\mathrm{U}$ \\
\hline S06E001041 & 0 & Acenaphthene & & $\operatorname{ug} \mathrm{Kg}$ & None & None & 79.3 & $<1.73 E+03$ & $<889$ & $\mathrm{n} / \mathrm{s}$ & $n / a$ & $\mathrm{n} / \mathrm{a}$ & n/a & 8009 & u \\
\hline SO6E001041 & o & Acenaphthylene & & ug $/ \mathrm{Kg}$ & None & None & $\mathrm{n} / \mathrm{a}$ & $<1.91 E+03$ & $\angle 9 B 2$ & $\mathrm{n} / \mathrm{a}$ & $\mathrm{n} / \mathrm{a}$ & $\mathrm{n} / \mathrm{a}$ & $\mathrm{n} / \mathrm{a}$ & 8821 & $\mathrm{u}$ \\
\hline SO6E001041 & 0 & Anthracene & & ug/Kg & None & None & $\mathrm{n} / \mathrm{a}$ & $<1.86 \mathrm{E}+03$ & $<954$ & $\mathrm{n} / \mathrm{a}$ & $\mathrm{n} / \mathrm{g}$ & $\mathrm{n} / \mathrm{a}$ & $\mathrm{n} / \mathrm{a}$ & 954 & U \\
\hline SO6E001041 & 0 & Benzo(a)anthracene & & ug/Kg & None & None & $\mathrm{na}$ & $<1.66 \mathrm{E}+03$ & 4852 & $\mathrm{n} / \mathrm{a}$ & $\mathrm{n} / \mathrm{a}$ & $\mathrm{n} / \mathrm{a}$ & $\mathrm{n} / \mathrm{a}$ & 852 & $\bar{u}$ \\
\hline S06E001041 & 0 & Benzo(a)pyrene & & ug/Kg & None & None & Na & $<1.58 E+03$ & $<813$ & $\mathrm{n} / \mathrm{a}$ & $n / a$ & $\mathrm{n} / \mathrm{a}$ & $\mathrm{n} / \mathrm{a}$ & 813 & u \\
\hline S06E001041 & 0 & Benzo(b)tluoranthene & & ug/Kg & None & None & $n / a$ & $<1.57 E+03$ & $\angle 804$ & $\mathrm{n} / \mathrm{a}$ & $\pi / a$ & $\mathrm{n} / \mathrm{a}$ & $\mathrm{Na}$ & 804 & u \\
\hline SO6E001041 & 0 & Benzo(g,h,i)perylene & & $\mathrm{ug} / \mathrm{Kg}$ & None & None & $n / a$ & $<1.58 \mathrm{E}+03$ & $<812$ & $n / a$ & $n / a$ & $n / a$ & $n / a$ & 812 & U \\
\hline SO6E001041 & 0 & Benzo(k)fluoranthene & & ug $/ \mathrm{Kg}$ & None & None & $\mathrm{N} / \mathrm{a}$ & $<1.64 E+03$ & $\angle 840$ & $n / a$ & $\mathrm{n} / \mathrm{a}$ & $\mathrm{n} / \mathrm{a}$ & n/a & $840 \sqrt{1}$ & $u$ \\
\hline
\end{tabular}

\section{Limit Vistated}


DSR - 20060609

TO2AZ TRAIN

\section{Sample Group: 20060609}

Core Number: 20060609

Sample Portion: Special Sample (Total)

Customer Sample ID: 702-AZ-2/3 SVOA

\begin{tabular}{|c|c|c|c|c|c|c|c|c|c|c|c|c|c|c|}
\hline \multirow[b]{2}{*}{ Stmplew R } & \multirow[b]{2}{*}{ A } & \multirow[b]{2}{*}{ Analytt } & \multirow[b]{2}{*}{ Unit } & \multicolumn{2}{|c|}{ Control Limits } & \multirow{2}{*}{ Standard $\%$} & \multirow[b]{2}{*}{ Elonk } & \multirow[b]{2}{*}{ Resuft } & \multirow[b]{2}{*}{ Duplicate } & \multirow[b]{2}{*}{ Average } & \multirow[b]{2}{*}{ RPD $\%$} & \multirow{2}{*}{ Spk Roe $\%$} & \multirow[b]{2}{*}{ Det LImis } & \multirow{2}{*}{ Qual Flaga } \\
\hline & & & & Low: & Upper & & & & & & & & & \\
\hline SOBE001041. & o & Butylbenzylphthalate & $\log / \mathrm{Kg}$ & Nóne & None & nia & $5.71 E+03$ & $2.73 \mathrm{E}+03$ & nta & $\mathrm{n} / \mathrm{a}$ & n/a & $n / a$ & $1.73 E+03 E$ & BJ \\
\hline S06E001041 & 0 & Crrysene & $\log / \mathrm{Kg}$ & None & None & na & $<1,63 E+03$ & $\angle 836$ & $\mathrm{n} / \mathrm{a}$ & $n / a$ & $\mathrm{n} / \mathrm{a}$ & n/a & & $\mathrm{U}$ \\
\hline SO6E001041 & 0 & Dj-n-butylphlhalate & $\log / \mathrm{Kg}$ & None & None & $\mathrm{n} / \mathrm{a}$ & $2.54 \mathrm{E}+04$ & $<5.77 E+03$ & nia & $\mathrm{n} / \mathrm{a}$ & $\mathrm{na}$ & $\mathrm{n} / \mathrm{a}$ & $5.77 E+03$ & $\mathrm{u}$ \\
\hline SO6E001041 & 0 & Di-n-octylphthalate & uog/Kg & None & None & nia & $<2.01 \mathrm{E}+03$ & $3.48 \mathrm{E}+03$ & $\mathrm{n} / \mathrm{a}$ & n/a & $\mathrm{n} / \mathrm{a}$ & n/a & $1.03 E+03$ & 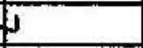 \\
\hline SO6E001041 & 0 & Dibenza, h) anthracens & ug/Kg & None & None & $\mathrm{n} / \mathrm{a}$ & $\angle 1.54 \mathrm{E}+03$ & 4788 & $n / a$ & $\mathrm{n} / \mathrm{a}$ & nia & n/a & 788 & $\mathrm{U}$ \\
\hline SOGE001041 & 0 & Dibenzofuran & ug/ $\mathrm{Kg}$ & None & None & $\mathrm{n} / \mathrm{a}$ & $\angle 1.71 \mathrm{E}+03$ & $<87 B$ & naf & $\pi / a$ & n'a & n/a & B789 & 4 \\
\hline SOEE001041 & 0 & Diettyyiphthalata & wo/kg & Nónef & None & $\mathrm{n} / \mathrm{a}$ & $<2.29 \mathrm{E}+03$ & $<1.18 E+03$ & $\mathrm{n} / \mathrm{a}$ & $n / a$ & $n^{\prime}$ & n/a & $1.18 E+03$ & $\mathrm{u}$ \\
\hline SOGE001041 & 0 & Dimethyiphthalais & ug/ $\mathrm{Kg}$ & None & None & $\mathrm{n} / \mathrm{a}$ & $<1.76 \mathrm{E}+03$ & $\quad<900$ & nal & $\mathrm{n} / \mathrm{a}$ & $\mathrm{n} / \mathrm{a}$ & n/a & $900 \mathrm{p}$ & $u$ \\
\hline SO6E001041 & 0 & Diphenylamine & ugikg & None & None & $\mathrm{n} / \mathrm{a}$ & $\$ 6.98 \mathrm{E}+03$ & $<.58 E+03$ & nia & $\mathrm{n} / \mathrm{a}$ & $\mathrm{n} / \mathrm{a}$ & nia & $3.56 \mathrm{E}+03 \mathrm{~L}$ & U \\
\hline SO6E001041 & 0 & Fluoranthene & $\log / \mathrm{K}_{\mathrm{g}}$ & None & None: & $\mathrm{n} / \mathrm{a}$ & $<1.78 E+03$ & $<912$ & niaj & $\mathrm{n} / \mathrm{a}$ & $n / a$ & n/a & 912 | & U \\
\hline SOGE001041 & o & Fluorene & $u g / K g$ & None & None & $\mathrm{n} / \mathrm{a}$ & $<1.71 E+03$ & $\angle B E D$ & $\mathrm{n} / \mathrm{a}$ & $n / a$ & $\mathrm{n} / \mathrm{a}$ & n/a & B8olt & U \\
\hline SO6E001041 & 0 & Hexachtorobenzene & ug/Kg & None & None & $n / a$ & $<1,89 E+03$ & $\angle B 67$ & na & $\mathrm{n} / \mathrm{a}$ & $n / a$ & $\mathrm{n} / \mathrm{a}$ & B67 & $\mathrm{u}$ \\
\hline SOGE001041 & o & Hexachlorobutadiene & ug $K g$ & None & None & $\pi / a)$ & $<1.80 \mathrm{E}+03$ & $<924$ & $\mathrm{n} / \mathrm{a}$ & $\mathrm{n} / \mathrm{a}$ & $\mathrm{r} / \mathrm{a}$ & $\mathrm{Na}$ & $924 \pi$ & u \\
\hline SOEE0001041 & 0 & Hexachlorocyclopentadlene & ug/ $/ \mathrm{Kg}$ & None & None & $n / a$ & $<285$ & $<146$ & $n / a$ & $\mathrm{n} / \mathrm{a}$ & n/a & n/a & 146 & 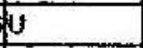 \\
\hline S06E001041 & 10 & Hexactloroethane & $\mathrm{ug} / \mathrm{Kg}$ & None: & None & $\mathrm{n} / \mathrm{a}$ & $<1.65 E+03$ & $<848$ & $n / a$ & $\mathrm{na}$ & $n / a$ & n/a & B48 & u \\
\hline S06E001041: & 0 & Indeno $(1,2,3-$-d $)$ pyrene & wog/Kg & None & None & $n / a$ & $<1.60 \mathrm{E}+03$ & $<822$ & nia & nal & $\mathrm{n} / \mathrm{a}$ & $\mathrm{Na}$ & 8221 & $\mathbf{U}$ \\
\hline SO6E001041 & 0 & Isophorone & ug/Kg & None & None & $\mathrm{n} / \mathrm{a}$ & $<1.54 \mathrm{E}+03$ & $<790$ & $n / \mathrm{a}$ & $n / a$ & त'/目 & nia & 790 & $\mathbf{u}$ \\
\hline SO6E001041 & 0 & N-Nitmosodipropylamine & $\operatorname{\omega og} / \mathrm{K}_{\mathrm{g}}$ & None & None & 80.5 & $\angle 1.60 \mathrm{E}+03$ & $<823$ & $\mathrm{n} / \mathrm{a}$ & $\mathrm{n} / \mathrm{a}$ & $\pi / 3$ & n/a & B23, & $u$ \\
\hline SOGE001041 & 0 & Naphthalene & $\mathrm{i} g / \mathrm{Kg}$ & None & None & $\mathrm{n} / \mathrm{a}$ & $<1.72 \mathrm{E}+03$ & $<882$ & $\pi / a$ & $\mathrm{n} / \mathrm{a}$ & $n / a$ & $\mathrm{Na}$ & $\mathrm{BB2}$ & $\mathbf{u}$ \\
\hline SO6E001044 & 0 & Nitrobenzene & ug/Kg: & None: & None: & $\mathrm{na}$ & $<1.79 \mathrm{E}+03$ & $<916$ & nia & $\mathrm{n} / \mathrm{a}$ & $\pi / a$ & $\mathrm{n} / \mathrm{a}$ & 916 & $u$ \\
\hline SO6E001041 & o & Pentachlorophenol & Leg/Kg & None & None & 88.3 & $<1.34 E+03$ & $<689$ & $n / a$ & $\mathrm{n} / \mathrm{a}$ & $\mathrm{n} / \mathrm{a}$ & na & 689 & $u$ \\
\hline SO6E001041 & $a$ & Phenanthrene & $1 \mathrm{~g} / \mathrm{Kg}$ & None & None & $\mathrm{n} / \mathrm{a}$ & $<1.69 E+03$ & $<866$ & $\mathrm{n} / \mathrm{a}$ & ntal & $n / a$ & nia & 866 & $u$ \\
\hline SO6E001041 & o & Phenol & ug/Kg & None & None & 76.9 & $<1.65 \mathrm{E}+03$ & $<845$ & $\mathrm{n} / \mathrm{a}$ & na & n'a & naa & B45 & $\mathrm{U}$ \\
\hline SO6E00 t041 & $\mathrm{o}$ & Pyrene & ugKkg & None & Nane & 92.9 & $<172 E+03$ & $<881$ & $\mathrm{~N} / \mathrm{a}$ & nta & $n / a$ & na & $881 / \mathrm{C}$ & U \\
\hline SOGEO001041 & 0 & Pysidine & ugg/Ka & None & None & $\mathrm{n} / \mathrm{a}$ & $41.58 E+03$ & $<811$ & nia & $n / a$ & $\mathrm{Na}$ & nia & 811 | & $\mathrm{u}$ \\
\hline SO6E001041 & 0 & Tri-n-butylphosphate & $\log / \mathrm{Kg}$ & None & None & $\mathrm{n} / \mathrm{a}$ & $5.38 \mathrm{E}+03$ & $<1.11 \mathrm{E}+03$ & $\mathrm{~N} / \mathrm{a}$ & $n / a$ & $n / a$ & na & $1.11 \mathrm{E}+03 \mathrm{C}$ & $\mathrm{U}$ \\
\hline SOEE001041 & 0 & bis(2-Chloroethoxy)methane & ug/kg & None & None & $\mathrm{n} / \mathrm{a}$ & $<1.79 \mathrm{E}+03$ & 8920 & naa & $\mathrm{n} / \mathrm{a}$ & $\mathrm{n} / \mathrm{a}$ & nia & 9201 & u \\
\hline SOEEOON1041 & 0 & bis \{2-Ethythexyl)phthałate & ug/Kg & None & None & $\mathrm{n} / \mathrm{a}$ & $<2.49 \mathrm{E}+04$ & $<+.28 E+04$ & na & n/a & $n / a$ & $\mathrm{n} / \mathrm{a}$ & $1.28 \mathrm{E}+04$ & $\bar{U}$ \\
\hline
\end{tabular}

\section{Haituriared}


Sample Group: 20060609

Core Number: 20060609

Sample Portion: Special Sample (Total)

Customer Sample ID: 702-AZ-2/3 SVOA

\begin{tabular}{|c|c|c|c|c|c|c|c|c|c|c|c|c|c|c|}
\hline \multirow[b]{2}{*}{ Samplo: $R$} & \multirow[b]{2}{*}{ AN } & \multirow[b]{2}{*}{ Analyte } & \multirow[b]{2}{*}{ Unit } & \multicolumn{2}{|c|}{ Control Limits } & \multirow[b]{2}{*}{ Standard \% } & \multirow[b]{2}{*}{ Blank } & \multirow[b]{2}{*}{ Result } & \multirow[b]{2}{*}{ Duplicate } & \multirow[b]{2}{*}{ Average } & \multirow[b]{2}{*}{ FPD $\%$} & \multirow[b]{2}{*}{ Spk Rac\% } & \multirow[b]{2}{*}{ Det Limit } & \multirow[b]{2}{*}{ Oual Flags } \\
\hline & & & & Lower] & Upper & & & & & & & & & \\
\hline S06E001041 & 10 & bis-(2-Chloroethyl) ether & $u g / K_{8}$ & None & Nane & $n / a$ & $<1.77 E+03$ & $<909$ & $n / a$ & $\mathrm{n} / \mathrm{a}$ & $n / 2$ & $\pi / a^{n}$ & 809 & \\
\hline
\end{tabular}

\section{Customer Sample ID: 702-AZ-2/3 WATER}

\begin{tabular}{|c|c|c|c|c|c|c|c|c|c|c|c|c|c|c|c|c|}
\hline \multirow[b]{2}{*}{ Sample: } & \multirow[b]{2}{*}{ A* } & \multirow[b]{2}{*}{ Analyte 4} & \multirow{2}{*}{ '. } & \multirow[b]{2}{*}{ ' } & \multirow[b]{2}{*}{ Unit } & \multicolumn{2}{|c|}{ Contrositimits } & \multirow[b]{2}{*}{ Standard $x$} & \multirow[b]{2}{*}{ Blank } & \multirow[b]{2}{*}{ Result } & \multirow[b]{2}{*}{ Duplicate } & \multirow[b]{2}{*}{ Average } & \multirow[b]{2}{*}{ RPD \% } & \multirow[b]{2}{*}{ SpkRac $\%$} & \multirow[b]{2}{*}{ Det Limit } & \multirow[b]{2}{*}{ Qual Flagss } \\
\hline & & & & & & Lower & Upper & & & & & & & & & \\
\hline SO6E001040 & $w$ & Nitrale & & & $u g / g$ & None & None & 101 & $<6.85$ & $468 \mathrm{E}+06$ & $\mathrm{n} / \mathrm{a}$ & nal & $n / a$ & n/a & $5.23 E+03$ & \\
\hline S06E001040 & $w$ & Acelate & 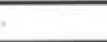 & & ug/g & None & None & 96.9 & $<578$ & $4.05 E+03$ & $\mathrm{n} / \mathrm{a}$ & nal & n/a & $\mathrm{n} / \mathrm{a}$ & $2.21 E+03$ & $J$ \\
\hline SO6E 001040 & w & Bromide & $z$ & & ug/g & None & Nane & 99.9 & $<312$ & $<1.19 E+03$ & $\mathrm{n} / \mathrm{a}$ & nial & $\mathrm{n} / \mathrm{a}$ & $\mathrm{N} / \mathrm{G}$ & $1.19 E+03$ & $U$ \\
\hline$S 08 E 001040$ & $w$ & Chiloride & $2 \quad+4$ & - & ug/g & None & None & 106 & $<0.850$ & $3.73 E+03$ & $\mathrm{n} / \mathrm{a}$ & nia & $\mathrm{n} / \mathrm{a}$ & nia & 162 & \\
\hline S06E001040 & w & Fluoride & & & ug/g & None & None & $\therefore 101$ & 30.0 & $<115$ & $\mathrm{n} / \mathrm{a}$ & nfa & $\mathrm{n} / \mathrm{a}$ & $n / \mathrm{s}$ & 115 & $\mathbf{u}$ \\
\hline S06E001040 & w & Formate & & & $u g / g$ & Nane & None & 104 & $<11.5$ & $<2.21 E+03$ & $n / a$ & nia & $\mathrm{n} / \mathrm{a}$ & $\mathrm{n} / \mathrm{B}$ & $2.21 E+03$ & U \\
\hline SO6E001040 & W & Glycolate & & & ug/g & Nane & Nona & 89.2 & $<478$ & $4.76 E+03$ & $\mathrm{n} / \mathrm{a}$ & na & $\mathrm{N} / \mathrm{a}$ & $n / a$ & $1.82 \mathrm{E}+03$ & $J$ \\
\hline SD6E001040 & $w$ & Nitrite & & & ug/g & None & None & 102 & $<5.40$ & $<1,03 E+03$ & nas & $\mathrm{Na}$ & $n / a$ & $n / a$ & $1.03 E+03$ & u \\
\hline $506 \mathrm{E} 001040$ & $w$ & Oxatate & 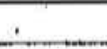 & & ug/g & Nane & None & 98.5 & $<5.25$ & $\angle 1.00 E+03$ & $\mathrm{n} / \mathrm{a}$ & $\mathrm{n} / \mathrm{a}$ & $n+a$ & $\mathrm{n} / \mathrm{a}$ & 1000 & $\mathrm{U}$ \\
\hline SD6E001040 & $w$ & Phosphate & 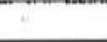 & & ug/g & None & Nons & 102 & $<302$ & $<1,16 E+03$ & $n / a$ & $\mathrm{Na}$ & $\mathrm{n} / \mathrm{a}$ & $n / 9$ & $116 E+03$ & $\mathrm{U}$ \\
\hline SD6E00 1040 & w & Sulfate & & & ug/9 & None & None & 102 & 46.90 & $1.94 \mathrm{E}+03$ & $\mathrm{n} / \mathrm{a}$ & nja & $n / a$ & nia & $132 E+03$ & \\
\hline
\end{tabular}

Customer Sample ID: 702-AZ-2A

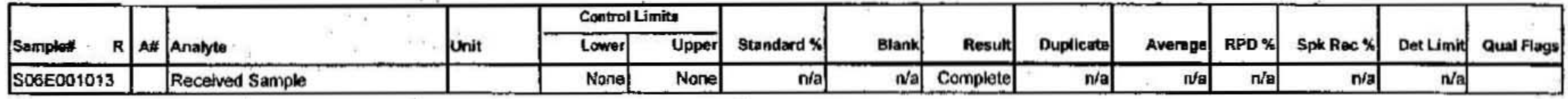

\section{Customer Sample ID: 702-AZ-2B}

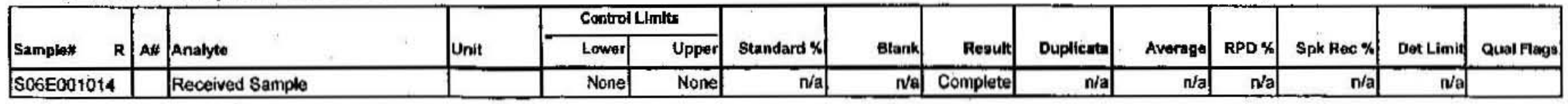

\section{Ginit vototat}


Sample Group: 20060609

Core Number: 20060609

Sample Portion: Special Sample (Total)

Customer Sample ID: 702-AZ-2C

\begin{tabular}{|c|c|c|c|c|c|c|c|c|c|c|c|c|c|c|}
\hline \multirow[b]{2}{*}{ Sample* $\quad \mathbf{R}$} & \multirow[b]{2}{*}{ A\# } & \multirow[b]{2}{*}{ Analyle } & & \multicolumn{2}{|c|}{ Controt Limits } & \multirow[b]{2}{*}{ Standard $\%$. } & \multirow[b]{2}{*}{ Blank } & \multirow[b]{2}{*}{ Resulf } & \multirow[b]{2}{*}{ Ouplicater } & \multirow[b]{2}{*}{ Avernge } & \multirow[b]{2}{*}{$R P D *$} & \multirow[b]{2}{*}{ Spk Rø X| } & \multirow[b]{2}{*}{ Det Limief } & \multirow[b]{2}{*}{ Oual Flags } \\
\hline & & & & Lown. & Upper & & & & & & & & & \\
\hline SUGE001015 & & Received Sample & & None & None & na| & n/a & Complete & $\mathrm{rof}$ & $n / a$ & na & $\mathrm{n} / \mathrm{a}$ & nia & \\
\hline
\end{tabular}

Customer Sample ID: 702-AZ-2D

\begin{tabular}{|c|c|c|c|c|c|c|c|c|c|c|c|c|c|c|}
\hline \multirow[b]{2}{*}{ Samples $\mathbf{R}$} & \multirow[b]{2}{*}{ Ant } & \multirow[b]{2}{*}{ Anatyte } & \multirow[b]{2}{*}{ Unit } & \multicolumn{2}{|c|}{ Control Limits } & \multirow[b]{2}{*}{ Standard \% } & \multirow[b]{2}{*}{ Blank } & \multirow[b]{2}{*}{ Result } & \multirow[b]{2}{*}{ Duplicato } & \multirow[b]{2}{*}{ Avernge } & \multirow[b]{2}{*}{ RPO $x$} & \multirow[b]{2}{*}{ Spk Rec X } & \multirow[b]{2}{*}{ Det Limin } & \multirow[b]{2}{*}{ Quad Fing } \\
\hline & & & & Lower| & Upper & & & & & & & & & \\
\hline SO6E001016 & & Received Sample & & None & None & $\mathrm{n} / \mathrm{a}$ & $\mathrm{N} / \mathrm{a}$ & Complete & $\mathrm{N} / \mathrm{a}$ & $\mathrm{n} / \mathrm{\theta}$ & $\mathrm{N} / \mathrm{a}$ & $\mathrm{n} / \mathrm{a}$ & $\mathrm{n} / \mathrm{a}$ & \\
\hline
\end{tabular}

Customer Sample ID: 702-AZ-2E

\begin{tabular}{|c|c|c|c|c|c|c|c|c|c|c|c|c|c|c|}
\hline \multirow[b]{2}{*}{ Samplen $\mathbf{R}$} & \multirow[b]{2}{*}{ A* } & \multirow[b]{2}{*}{ Anslyt to } & \multirow[b]{2}{*}{ Unit } & \multicolumn{2}{|c|}{ Control Limits } & \multirow[b]{2}{*}{ Standard $\times / 0$} & \multirow[b]{2}{*}{ Blank } & \multirow[b]{2}{*}{ Reoun } & \multirow[b]{2}{*}{ Dupliealo } & \multirow[b]{2}{*}{ Average } & \multirow[b]{2}{*}{ RPD $\times$} & \multirow[b]{2}{*}{ Spk Rex $\%$} & \multirow[b]{2}{*}{ Det Uimit } & \multirow[b]{2}{*}{ Dumb Flagn } \\
\hline & & & & Lower & Upper & & & & & & & & & \\
\hline SOSE001017 & & Recrived Sampla & & None [ & None & n/a & $n / a$ & Complete & $\mathrm{N} / \mathrm{B}$ & $\mathrm{n} / \mathrm{a}$ & $\mathrm{n} / \mathrm{a}$ & $\mathrm{n} / \mathrm{a}$ & กลa & \\
\hline
\end{tabular}

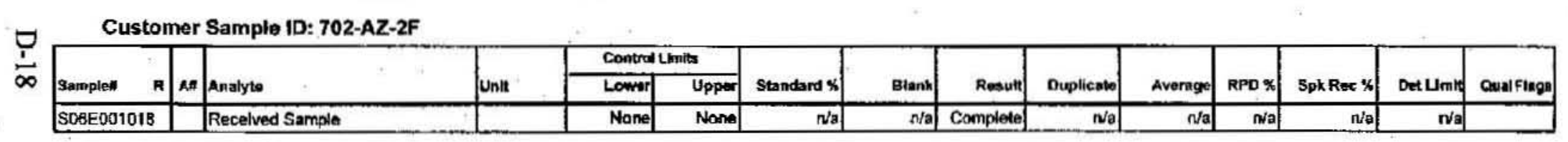

Customer Sample ID: 702-AZ-SAB-BLK

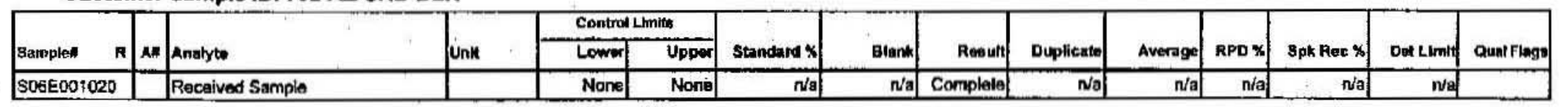

Customer Sample ID: 702-AZ-SAB-FBLK

\begin{tabular}{|c|c|c|c|c|c|c|c|c|c|c|c|c|c|c|}
\hline \multirow{2}{*}{ Samples $\quad \mathbf{R}$} & \multirow[b]{2}{*}{ an } & \multirow{2}{*}{ Analyte } & \multirow[b]{2}{*}{ Unit } & \multicolumn{2}{|c|}{ Controf Limits } & \multirow[b]{2}{*}{ Stancard $x$} & \multirow[b]{2}{*}{ Blank: } & \multirow[b]{2}{*}{ Result } & \multirow[b]{2}{*}{ DupHeata } & \multirow[b]{2}{*}{ Average } & \multirow[b]{2}{*}{$R P D \times$} & \multirow[b]{2}{*}{ Spk Rec X } & \multirow{2}{*}{ Dot Limit } & \multirow[b]{2}{*}{ Qual Flagg: } \\
\hline & & & & Lower & Upper & & & & & & & & & \\
\hline SO6E001022 & & Received Samplo & & None & None & $\mathrm{n} / \mathrm{a}$ & $\mathrm{n} / \mathrm{a}$ & Complete & $\mathrm{n} / \mathrm{a}$ & n'a & $n+a$ & na & $\pi / 2$ & \\
\hline
\end{tabular}

Limit violated 
Sample Group: 20060609

Core Number: 20060609

Sample Portion: Special Sample (Total)

Customer Sample ID: 702-AZ-SAB-TRPBLK

\begin{tabular}{|c|c|c|c|c|c|c|c|c|c|c|c|c|c|c|}
\hline & & & & Controt & & & & & & & & & & \\
\hline Samplest & An & Analyta & Unit & Lowar & Upper & Standard $\mathrm{x}$ & Blimk & Resun & Dupticate & Average & RPO $\%$ & $\operatorname{Spk} \operatorname{Rac} \%$ & DetLimin & Qual fling \\
\hline S06E001024 & & Received Sample & & None & Nane & \begin{tabular}{c|c|} 
nig \\
\end{tabular} & $n / a$ & Complete & $n / a$ & $n / a$ & $\mathrm{Na}$ & $n / 0$ & $n / a \mid$ & \\
\hline
\end{tabular}

\begin{tabular}{|c|c|c|c|c|c|c|c|c|c|c|c|c|c|c|}
\hline \multirow[b]{2}{*}{ Semples $R$} & \multirow[b]{2}{*}{ An } & \multirow{2}{*}{ Analyto } & \multirow[b]{2}{*}{ Unit } & \multicolumn{2}{|c|}{ Controlumits } & \multirow[b]{2}{*}{ Standard $x$} & \multirow[b]{2}{*}{ Btank } & \multirow[b]{2}{*}{ Reascute } & \multirow[b]{2}{*}{ Dupliconta } & \multirow[b]{2}{*}{ Average } & \multirow[b]{2}{*}{ PPO $x$} & \multirow[b]{2}{*}{ Spk Rec $x$} & \multirow[b]{2}{*}{ Dot Limm } & \multirow[b]{2}{*}{ Oual flogss } \\
\hline & & & & Lowor & Upper & & & & & & & & & \\
\hline S06E001019 & & Received Sarmple & & None & None & nia & nat & Compitete & nat & $\mathrm{N} / \mathrm{a}$ & $n$ n'a & $n / a$ & $n / a$ & \\
\hline
\end{tabular}

\begin{tabular}{|c|c|c|c|c|c|c|c|c|c|c|c|c|c|c|}
\hline \multirow[b]{2}{*}{ Sample\# $R$} & \multirow[b]{2}{*}{ R A A* } & \multirow{2}{*}{ Analyte } & \multirow[b]{2}{*}{ Unit } & \multicolumn{2}{|c|}{ Control Limits } & \multirow[b]{2}{*}{ standart of } & \multirow[b]{2}{*}{ Blank } & \multirow[b]{2}{*}{ Rosulk } & \multirow[b]{2}{*}{ Duplicato } & \multirow[b]{2}{*}{ Avernge } & \multirow[b]{2}{*}{ RPD $\times 1$} & \multirow[b]{2}{*}{ Spk Roe $\mathrm{X}$. } & \multirow[b]{2}{*}{ Det Linnis } & \multirow[b]{2}{*}{ Dum rasag: } \\
\hline & & & & Lowor & Upper & & & & & & & & & \\
\hline S06E001021 & & Received Sample & & None & None & $n / a$ & nva & Complete & $\mathrm{n} / \mathrm{a}$ & n/a & nat & $r \dot{H}$ & $\pi / 2$ & \\
\hline
\end{tabular}

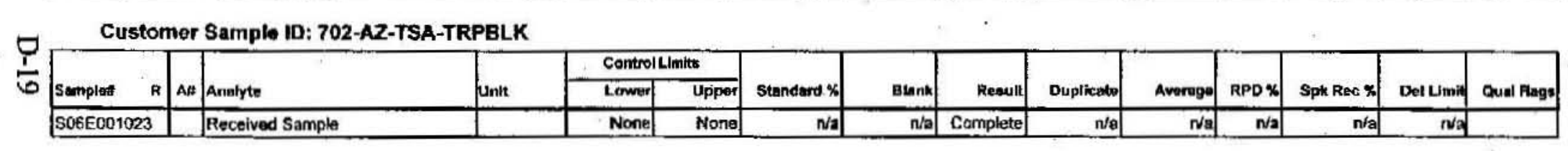

\begin{tabular}{|c|c|c|c|c|c|c|c|c|c|c|c|c|c|c|}
\hline \multirow[b]{2}{*}{ Sampleat $\quad$ R } & \multirow[b]{2}{*}{ P At } & \multirow{2}{*}{ Analyte } & \multirow[b]{2}{*}{ Uninte } & \multicolumn{2}{|c|}{ Control Limits } & \multirow[b]{2}{*}{ Btandard $\mathrm{K}$} & \multirow[b]{2}{*}{ Btank } & \multirow[b]{2}{*}{ Resurt } & \multirow[b]{2}{*}{ Dupplicater } & \multirow[b]{2}{*}{ Average } & \multirow[b]{2}{*}{ RPD X } & \multirow[b]{2}{*}{ Spt Rec \% } & \multirow[b]{2}{*}{ Det Liming f } & \multirow[b]{2}{*}{ Qual Flags: } \\
\hline & & & & Lomor & Upper & & & & & & & & & \\
\hline SO6E001043 & & Differentlal Scanning Calorimetry E & Joules/g & None & Nonet & n/a & n/a & 302 & तa & $n / a$ & $\mathrm{~N} / \mathrm{a}$ & $\pi / 5$ & $n / a$ & \\
\hline
\end{tabular}

\section{Customer Sampla ID: 702AZ TRAIN NH4NO3-NACL}

\begin{tabular}{|c|c|c|c|c|c|c|c|c|c|c|c|c|c|}
\hline \multirow[b]{2}{*}{ Sampleat $\quad R$} & \multirow[b]{2}{*}{ A An Analyte } & \multirow[b]{2}{*}{ Unit } & \multicolumn{2}{|c|}{ Control Limits } & \multirow[b]{2}{*}{ Stanctard $\%$} & \multirow[b]{2}{*}{ Blank } & \multirow[b]{2}{*}{ Resunt } & \multirow[b]{2}{*}{ Duplicenter } & \multirow[b]{2}{*}{ Avernge } & \multirow[b]{2}{*}{ RPO \% } & \multirow[b]{2}{*}{ SpkRec $\times$} & \multirow[b]{2}{*}{ Det Limit } & \multirow[b]{2}{*}{ Oual Flag: } \\
\hline & & & Low & Upper & & & & & & & & & \\
\hline SO6E001044 & Difterential Scanning Calorimetry $\mathrm{E}$ & Joules/g & None & None & $\mathrm{Na}$ & $\pi / a$ & 504 & $n / a \mid$ & na & n/a & n/a & nat & \\
\hline
\end{tabular}

Limit Violated 
RPP-RPT-31293, Rev. 0

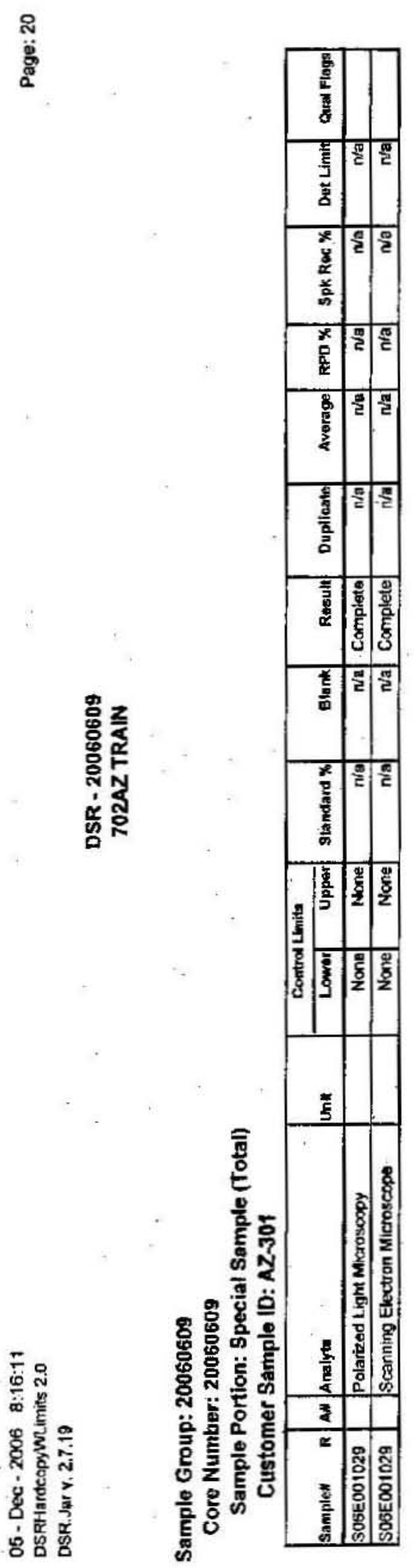


Sample: S06E001025

Size: $14.8200 \mathrm{mg}$

Method: Sample
Comment: 702AZ TRAIN

TGA

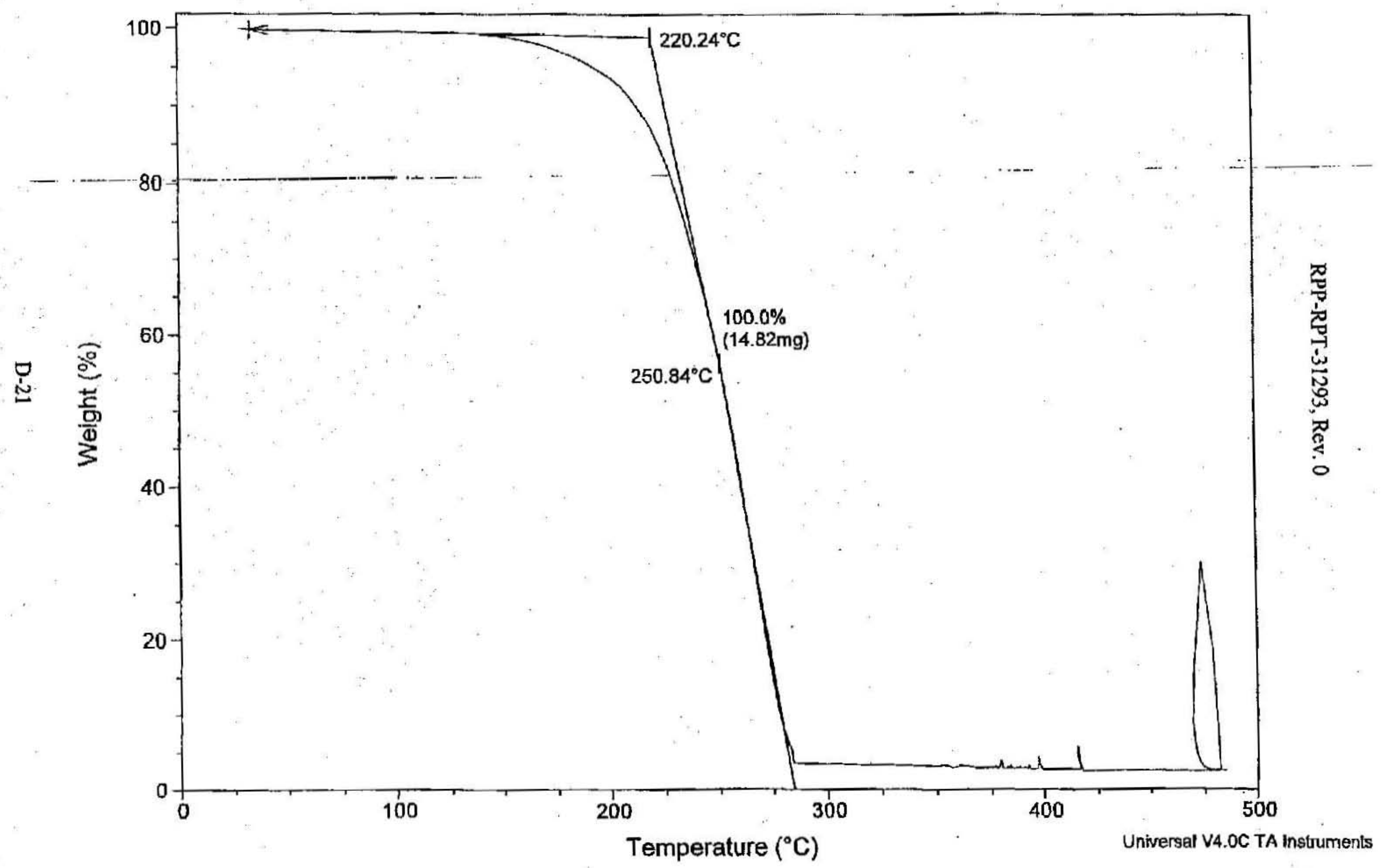

File: C:ITAIDataITGA-GISAM072406.001

Operator: RWK

Run Date: 24-Jul-2006 10:10

Instrument: 2050 TGA V5.4A 
Sample: S06E001025 DUP

Size: $15.9300 \mathrm{mg}$

Method: Sample

Comment: 702AZ TRAIN
TGA

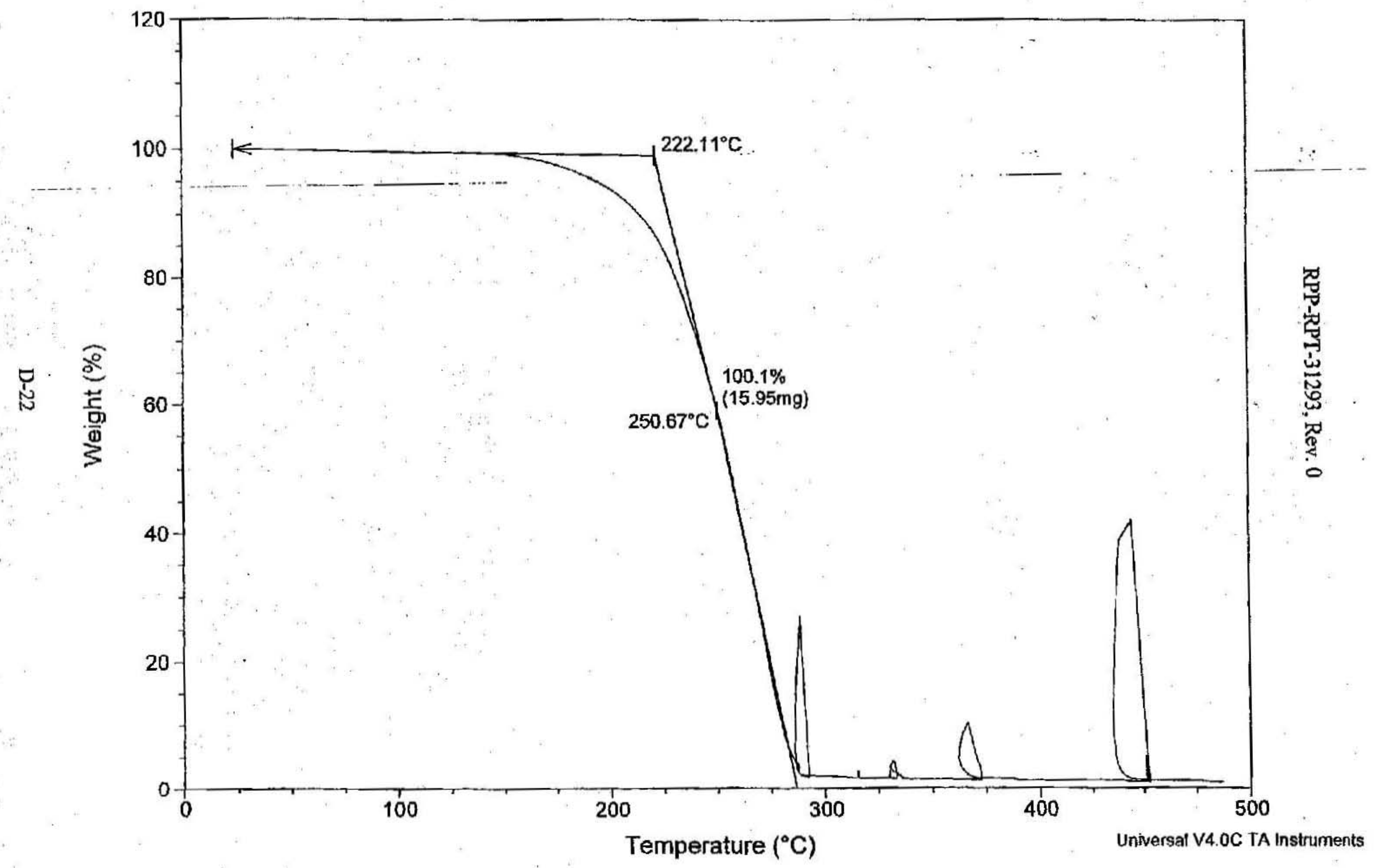

File: C:ITAIDatalTGA-6ISAM072406.002

Operator: RWK

Run Dafe: 24-Jul-2006 12:52

Instrument: 2050 TGA V5.4A 
Sample: S06E001042

Size: $31.2950 \mathrm{mg}$

Method: Sample

Comment: 702 AZ TRAIN
File: C:ITAIDataITGA-6ISAM080806.001

Operator: RWK

Run Date: 08-Aug-2006 11:15

Instrument: 2050 TGA V5.4A

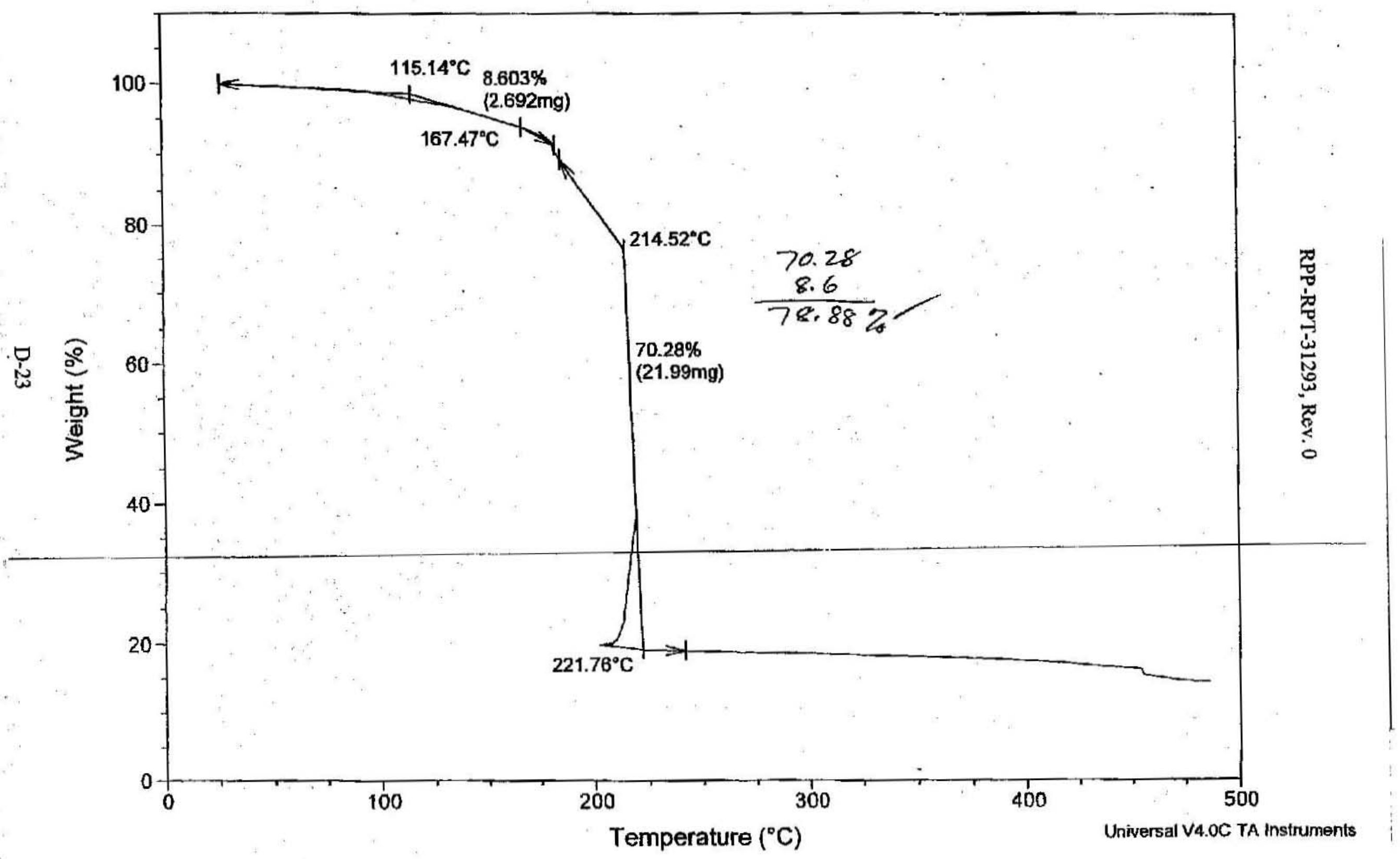


Sample: S06E001042 DUP

Size: $20.3540 \mathrm{mg}$

Method: Sample

Comment: 702 AZ TRAIN
File: C:ITAIDataITGA-6ISAM080806.002

Operator: RWK

Run Date: 08-Aug-2006 13:35

Instrument: 2050 TGA V5.4A

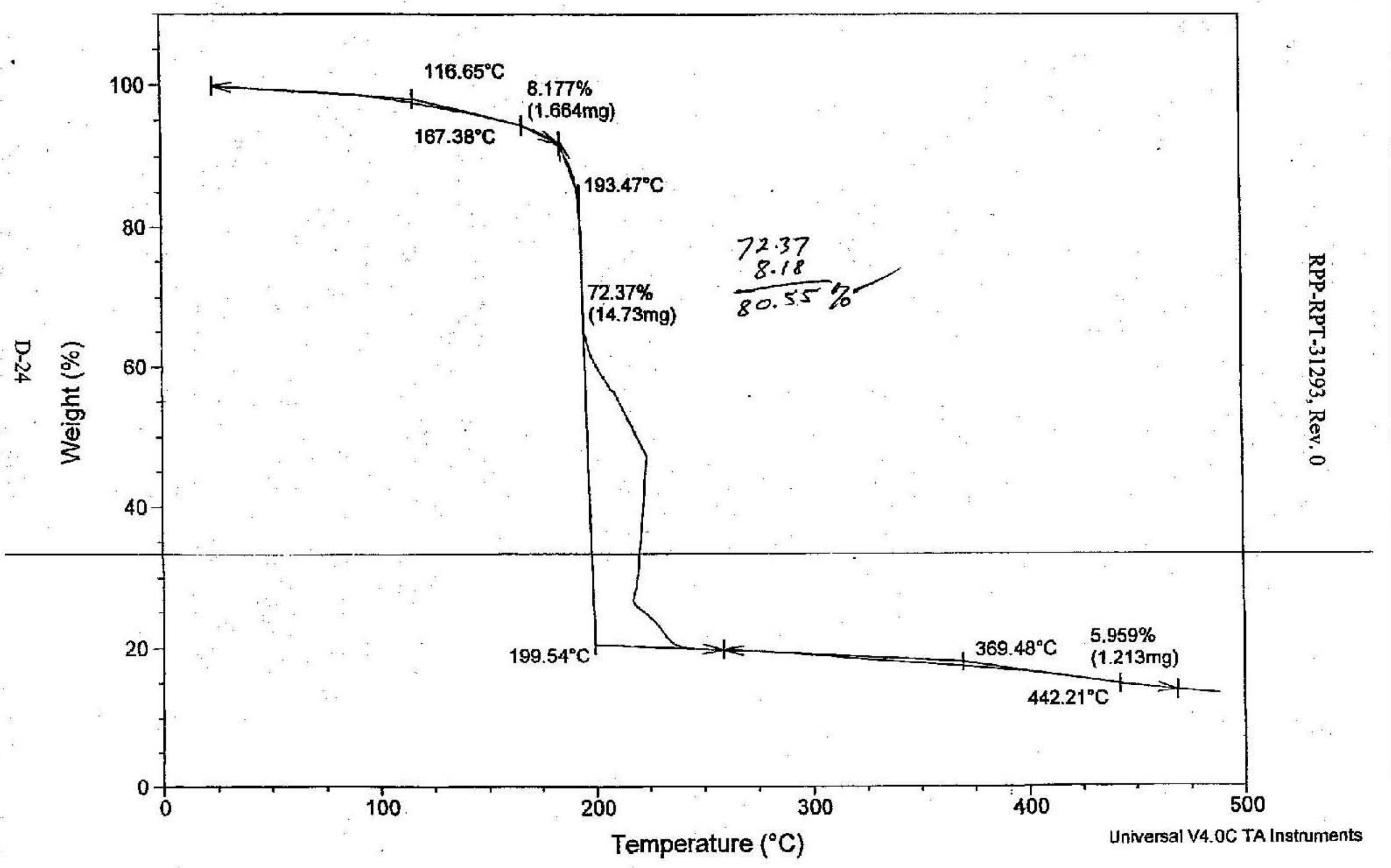


Sample: S06E001025

Size: $11.6700 \mathrm{mg}$

Method: Sample

DSC

Comment: SAM
File: C:ITAIDataIDSC-4ISAM080806.A01

Operator: RWK

Run Date: 08-Aug-2006 13:26

Instrument: 2920 DSC V2.6A

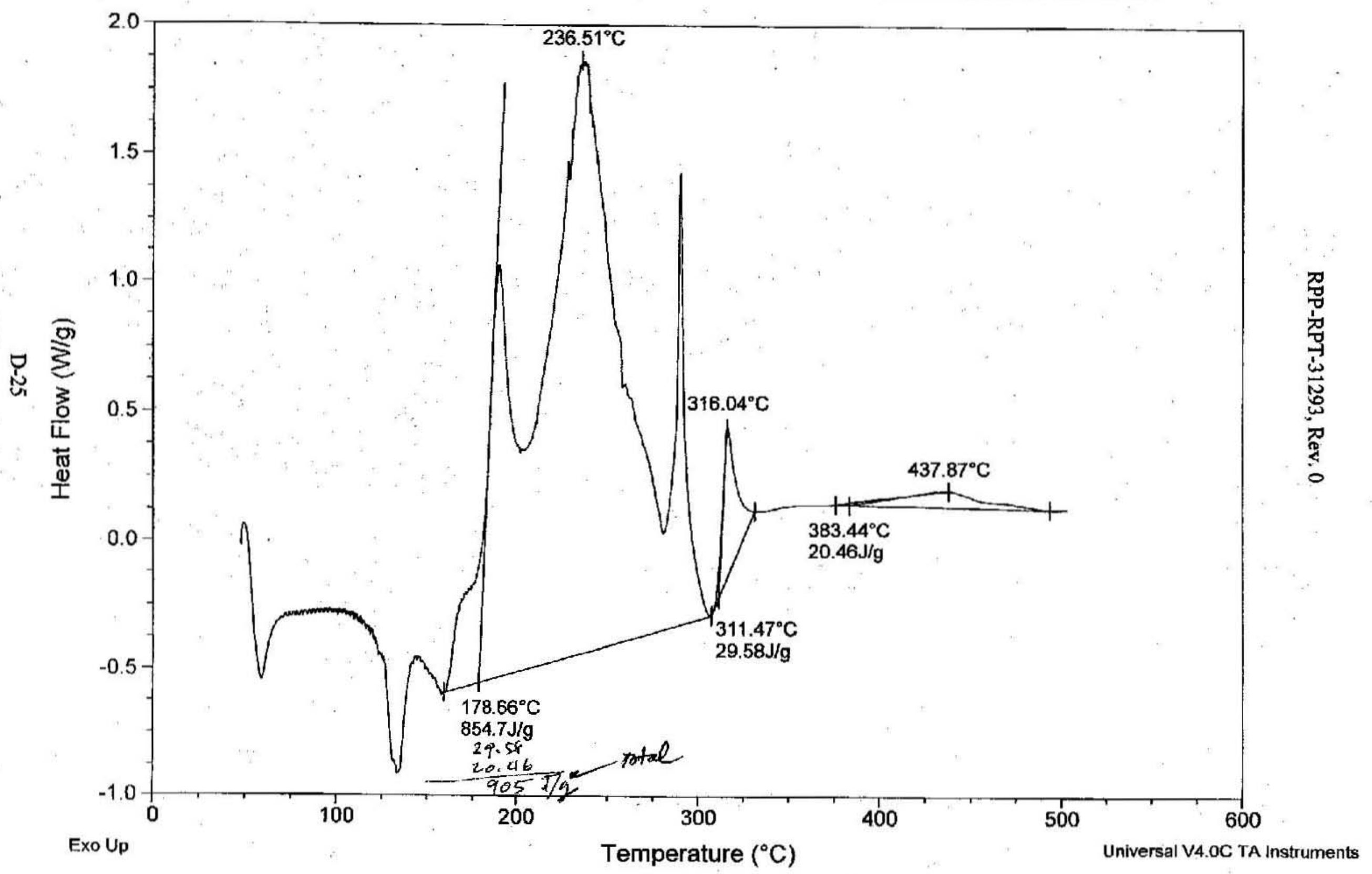


Sample: S06E001025 DUP

Size: $11.2400 \mathrm{mg}$

Method: Sample

Comment: SAM

DSC

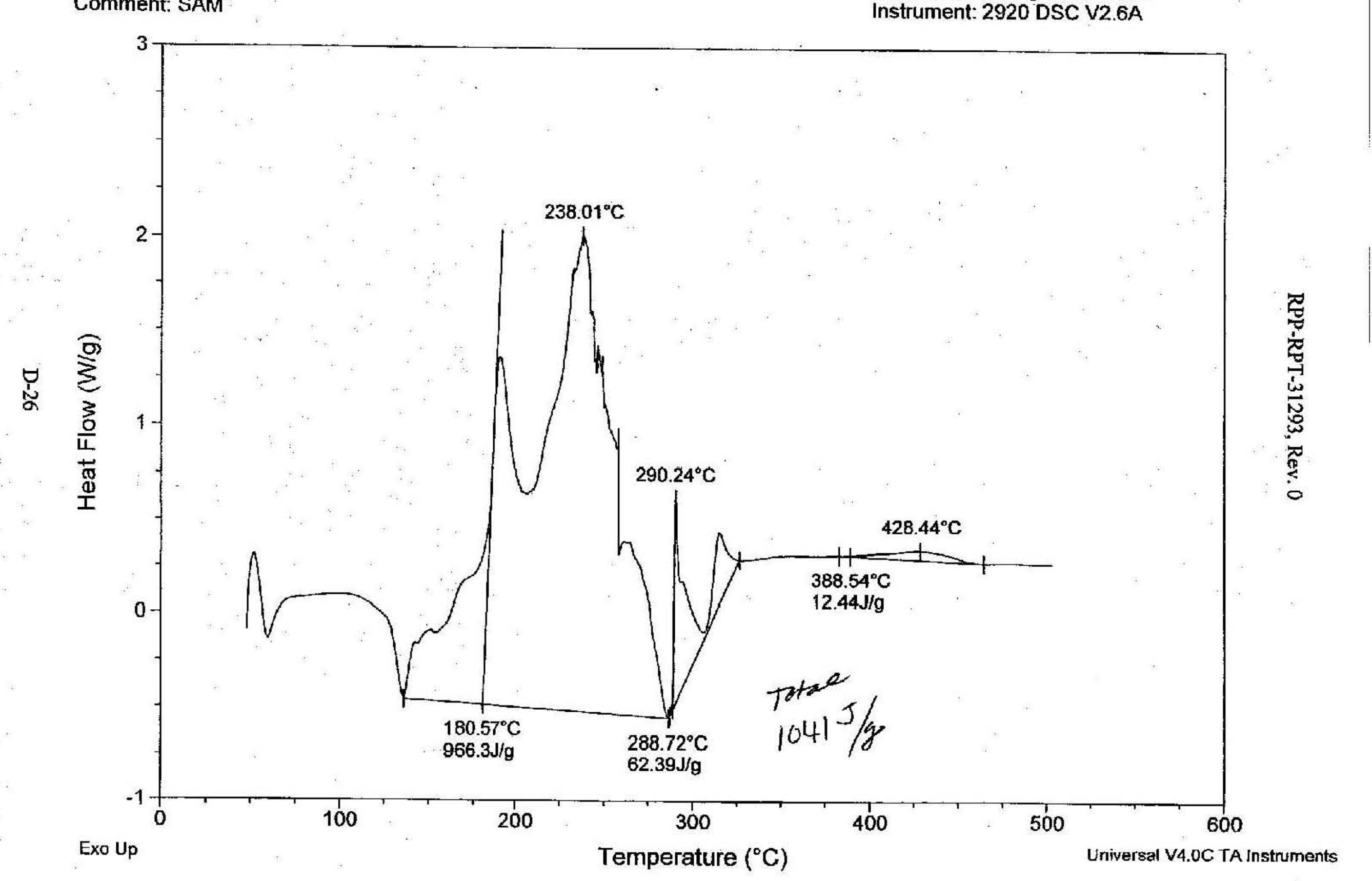

File: C:ITAIDatalDSC-4ISAM080806.B01

Operator: RWKJBVD

Run Date: 08-Aug-2006 13:26

Instrument: 2920 DSC V2. 6 A 
Sample: S06E001042

Size: $24.9300 \mathrm{mg}$

Method: Sample

DSC

Comment: SAM
File: C:ITAIDataIDSC-4ISAM080806.A02

Operator: RWK

Run Date: 08-Aug-2006 14:59

Instrument: 2920 DSC V2.6A

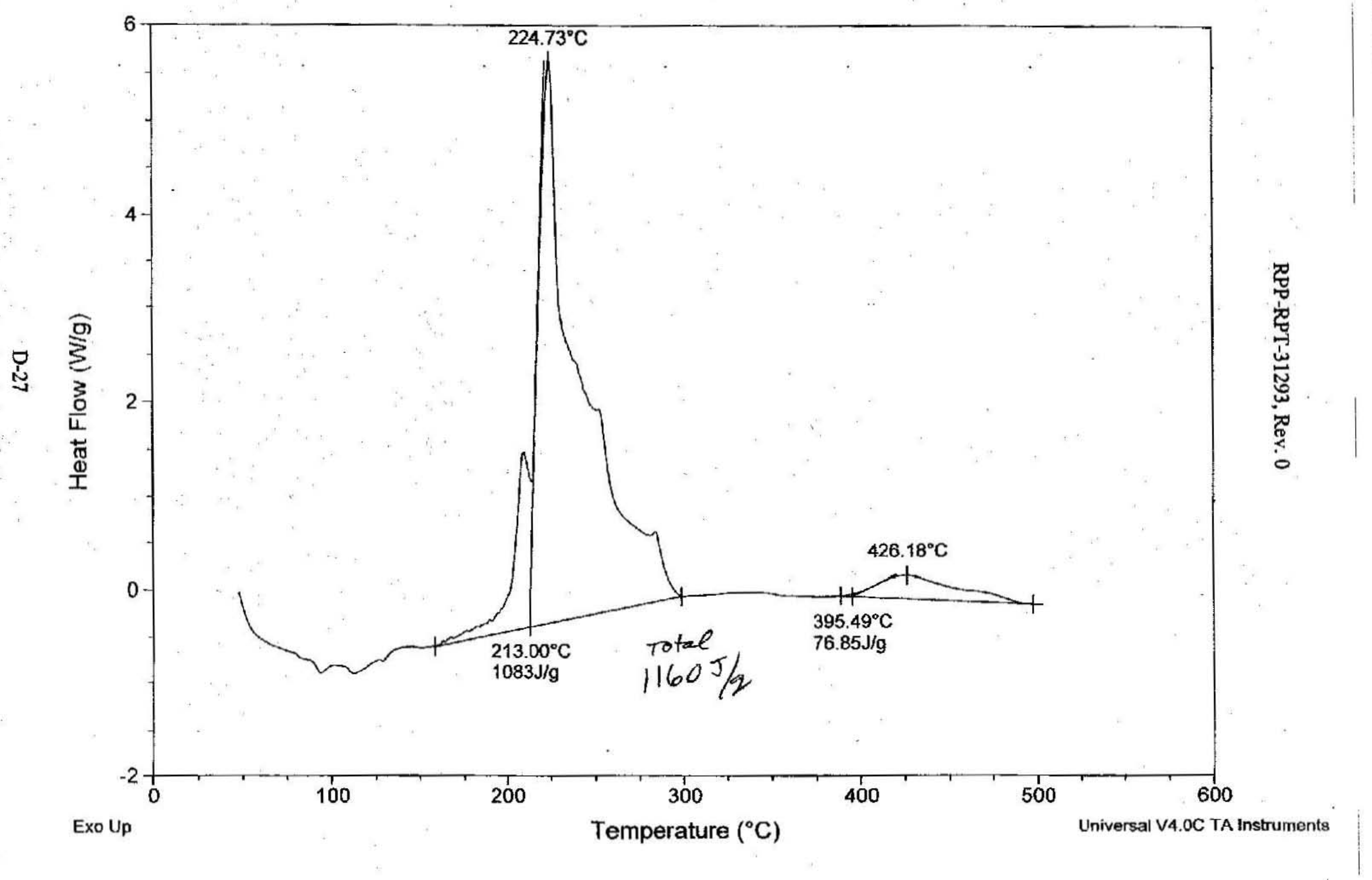


Sample: S06E001043

Size: $10.7500 \mathrm{mg}$

Method: Sample

DSC

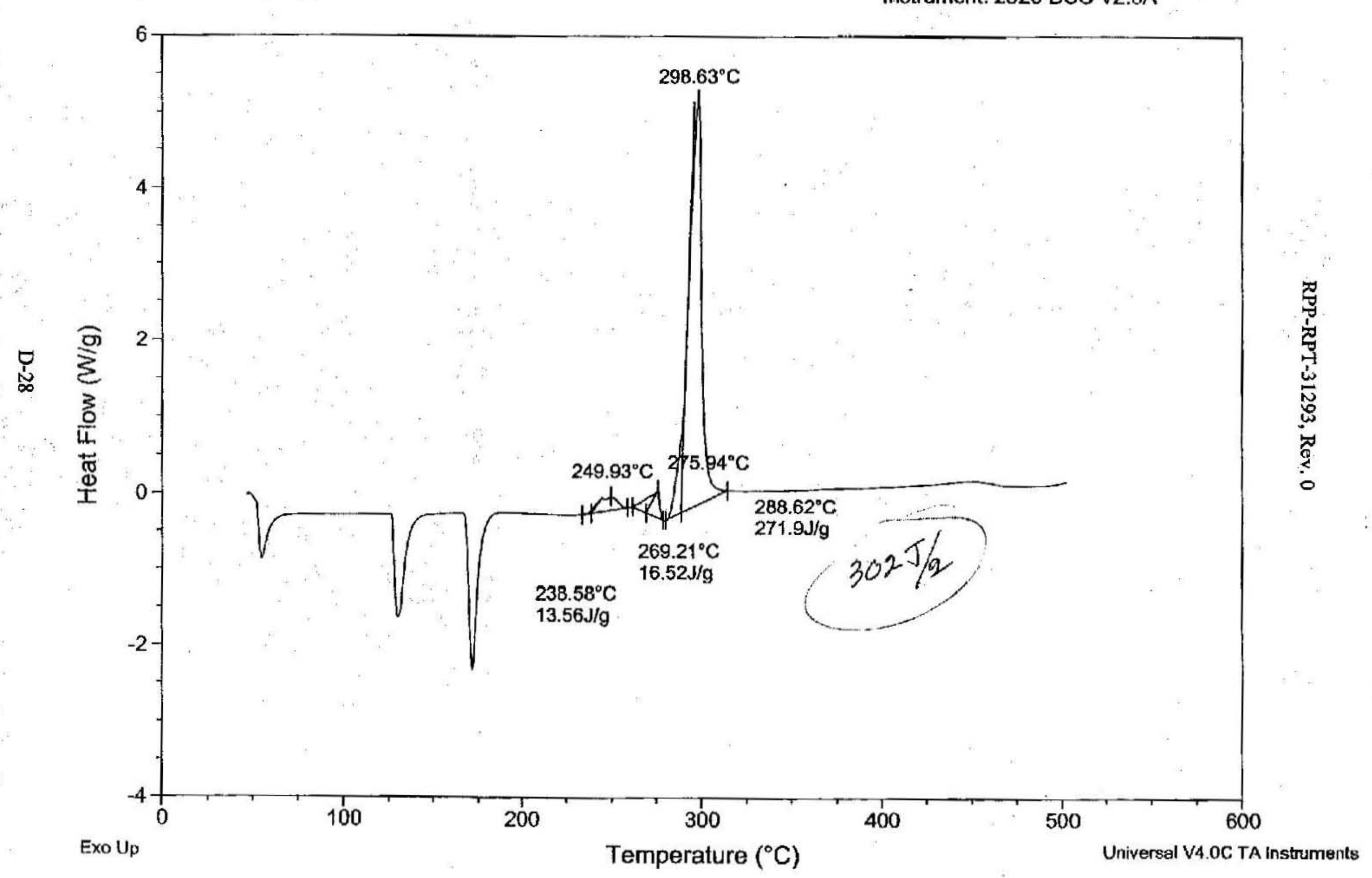

File: C:ITALDatalDSC-5ISAM092706 A01

Operator: RWK

Run Date: 27-Sep-2006 10:53

Instrument: 2920 DSC V2.6A 
Sample: S06E001044

Size: $17.9700 \mathrm{mg}$

Method: Sample
File: C:ITAIDatalDSC-5ISAM092706.B01

\section{Operator: RWK}

Run Date: 27-Sep-2006 10:53

Instrument: 2920 DSC V2.6A

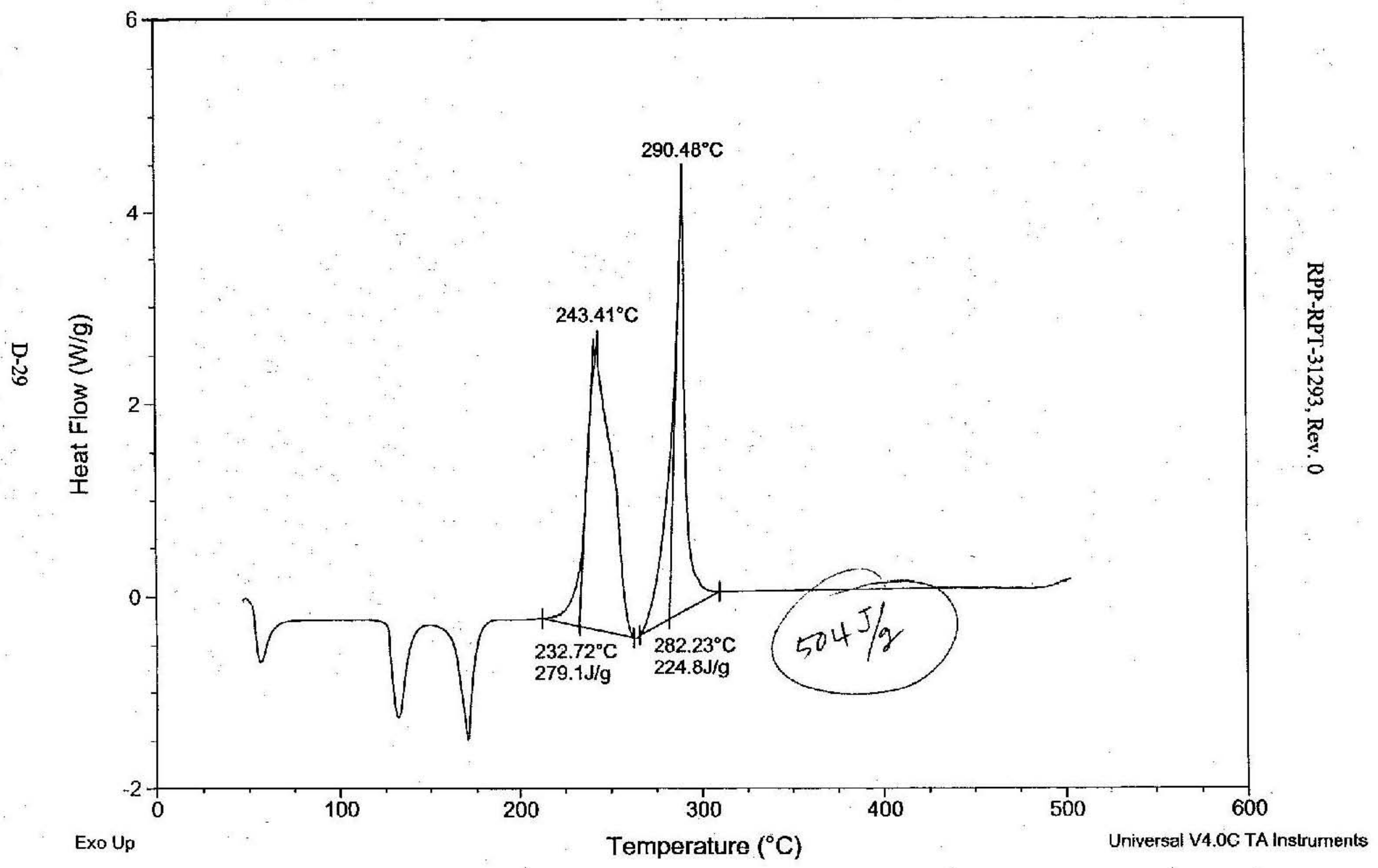


Sample: S06E001045

Size: $11.1300 \mathrm{mg}$

Method: Sample

DSC

Comment: Air Purge
File: C:ITAIDataWSC-5ISAM100506.A01 Operator: KRM

Run Date: 05-Oct-2006 10:00

Instrument: 2920 DSC V2.6A

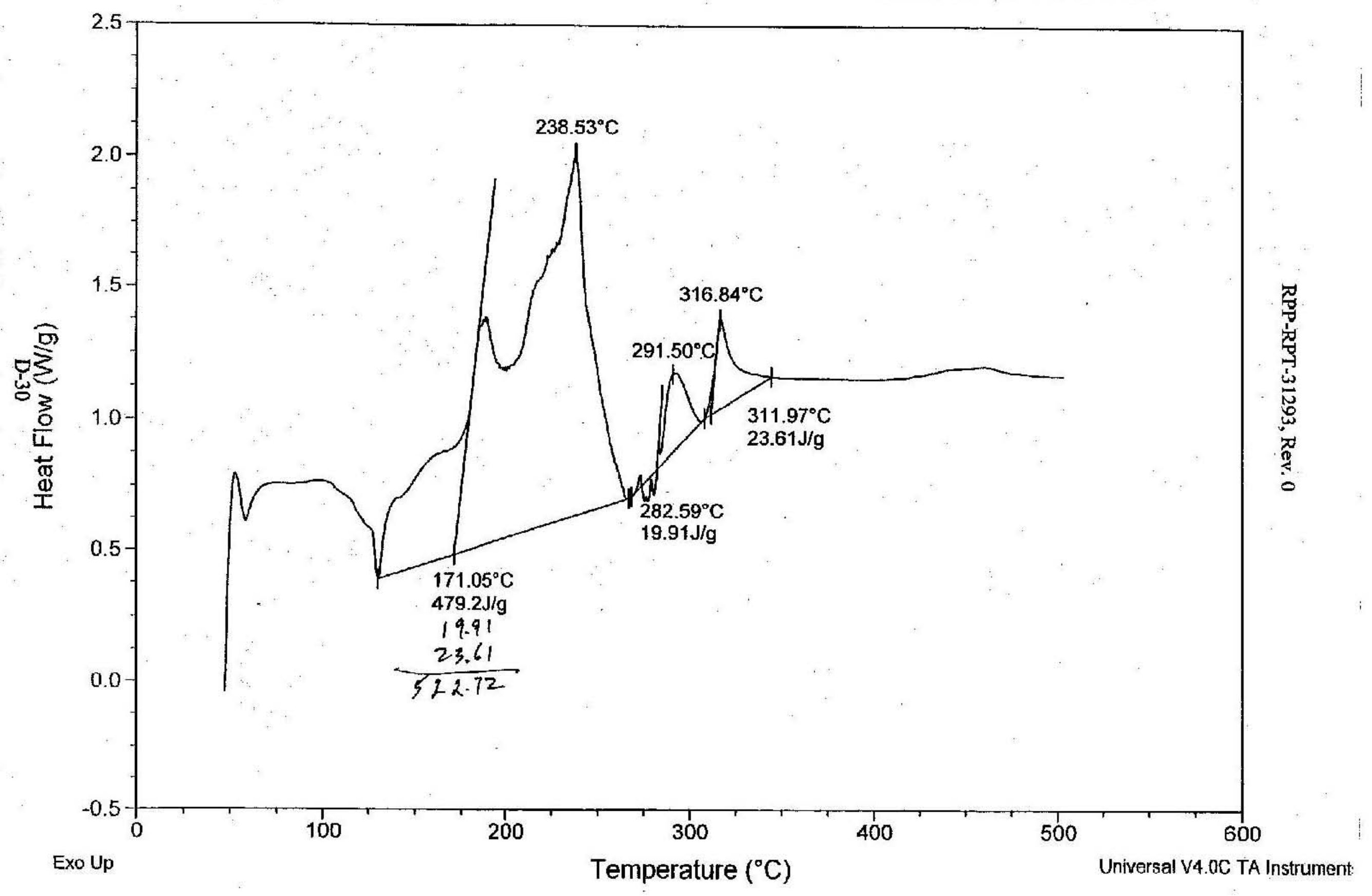


Sample: S06E001046

Size: $9.7000 \mathrm{mg}$

Method: Sample

DSC

Comment: Air Purge
File: C:ITAIDataIDSC-5ISAM100506.B01

Operator: KRM

Run Date: 05-Oct-2006 10:00

Instrument: 2920 DSC V2.6A

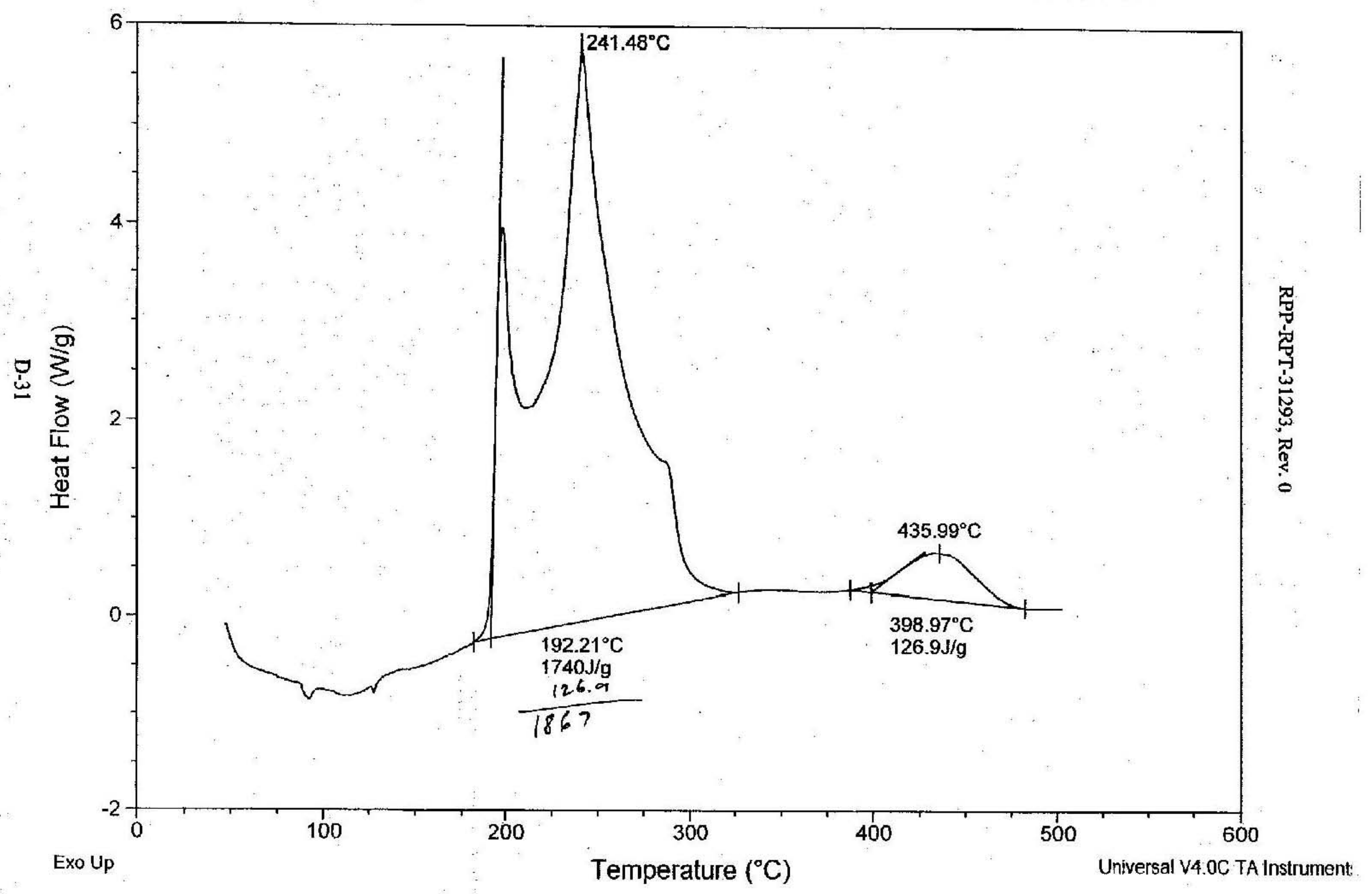


Page 143 of 162 of DA04063678

RPP-RPT-31293, Rev. 0

APPENDIX E

SCANNING ELECTRON MICROSCOPY

E-i 
Sample S06E001025

Figure E-1. Grains of ammonium nitrate, note shrinkage cracks.

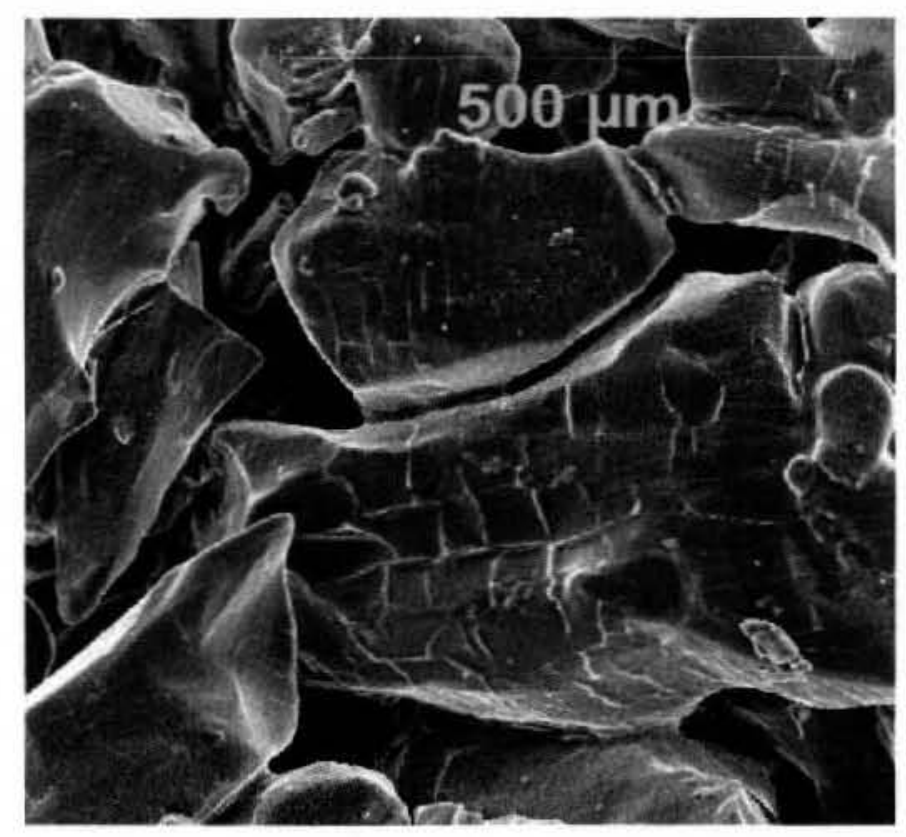

Figure E-2. EDS spectra of ammonium nitrate crystals in Figure E-1.

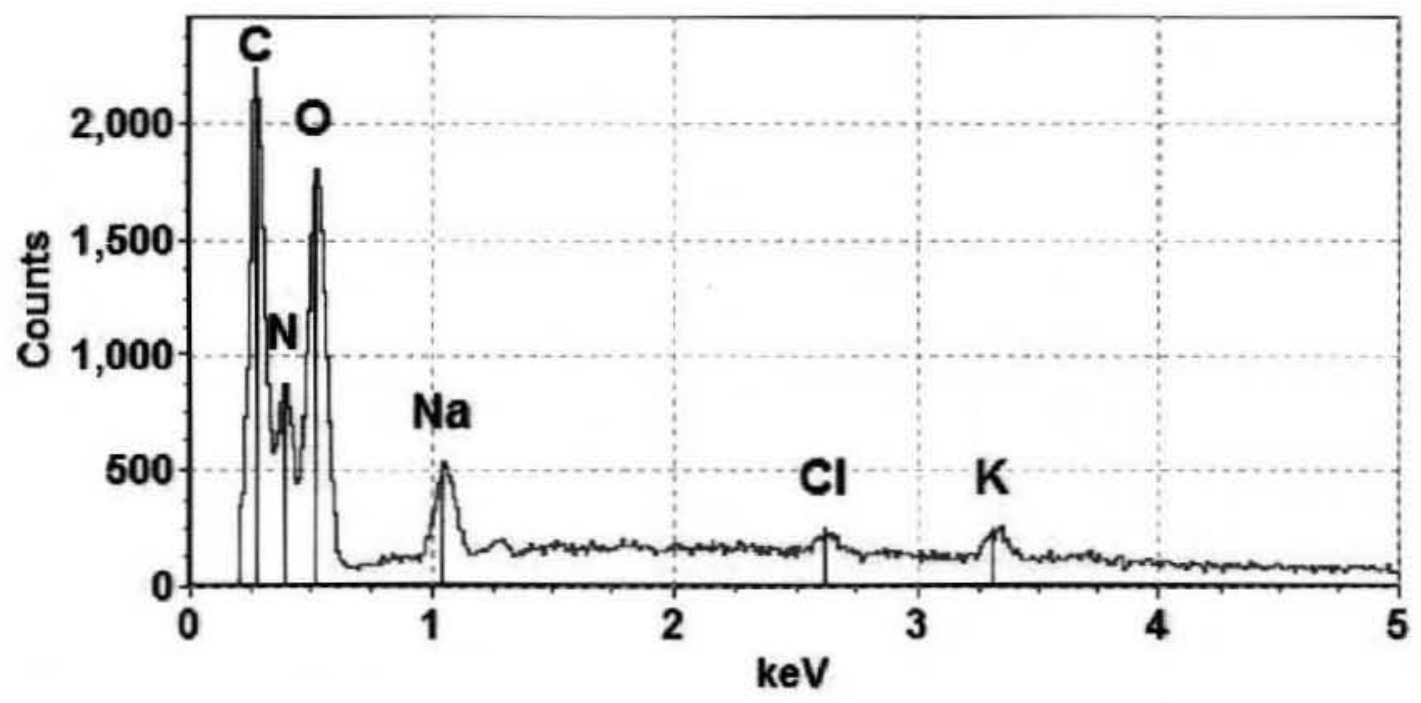

Note the strong nitrogen peak in the Figure E-2 EDS spectra. The nitrogen peak is typically not observable in EDS spectra because of masking by the carbon (C) peak, unless it is prevalent as a major element of the material. The large $\mathrm{C}$ peak is an artifact of SEM slide preparation. 
Sample S06E001026

Figure E-3. The upper photo is low magnification "field view" of organic-cemented aggregate from sample S06E001026. Yellow boxes mark area expanded in the photos below. The EDS results from the spot marked with a "+" in the photo above the corresponding spectrum.

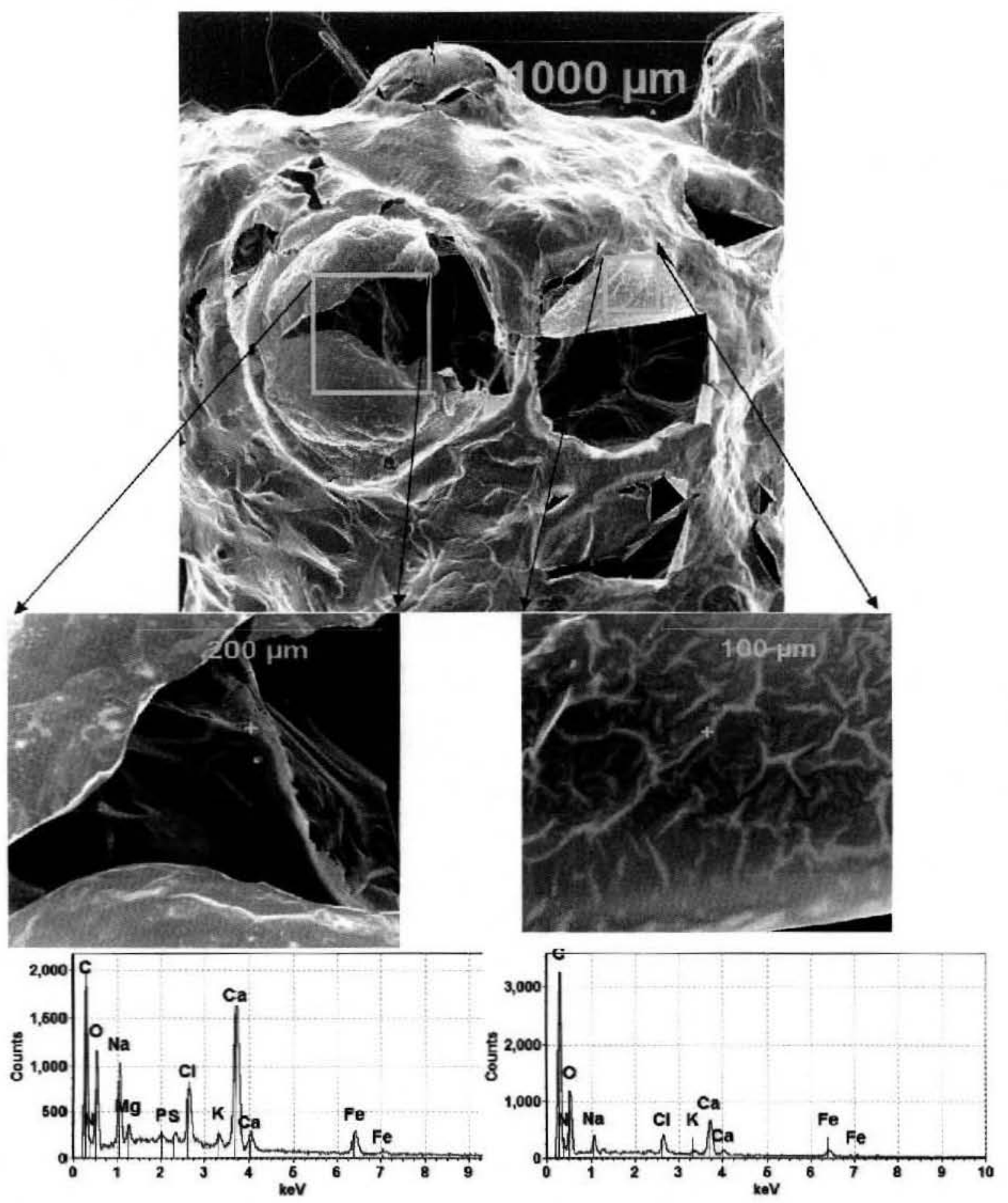




\section{Sample S06E001042}

Figure E-4. Portion of sample rinsed with methanol showing particle of ammonium nitrate, note dissolution features. Right image is blow up of area in box on left image

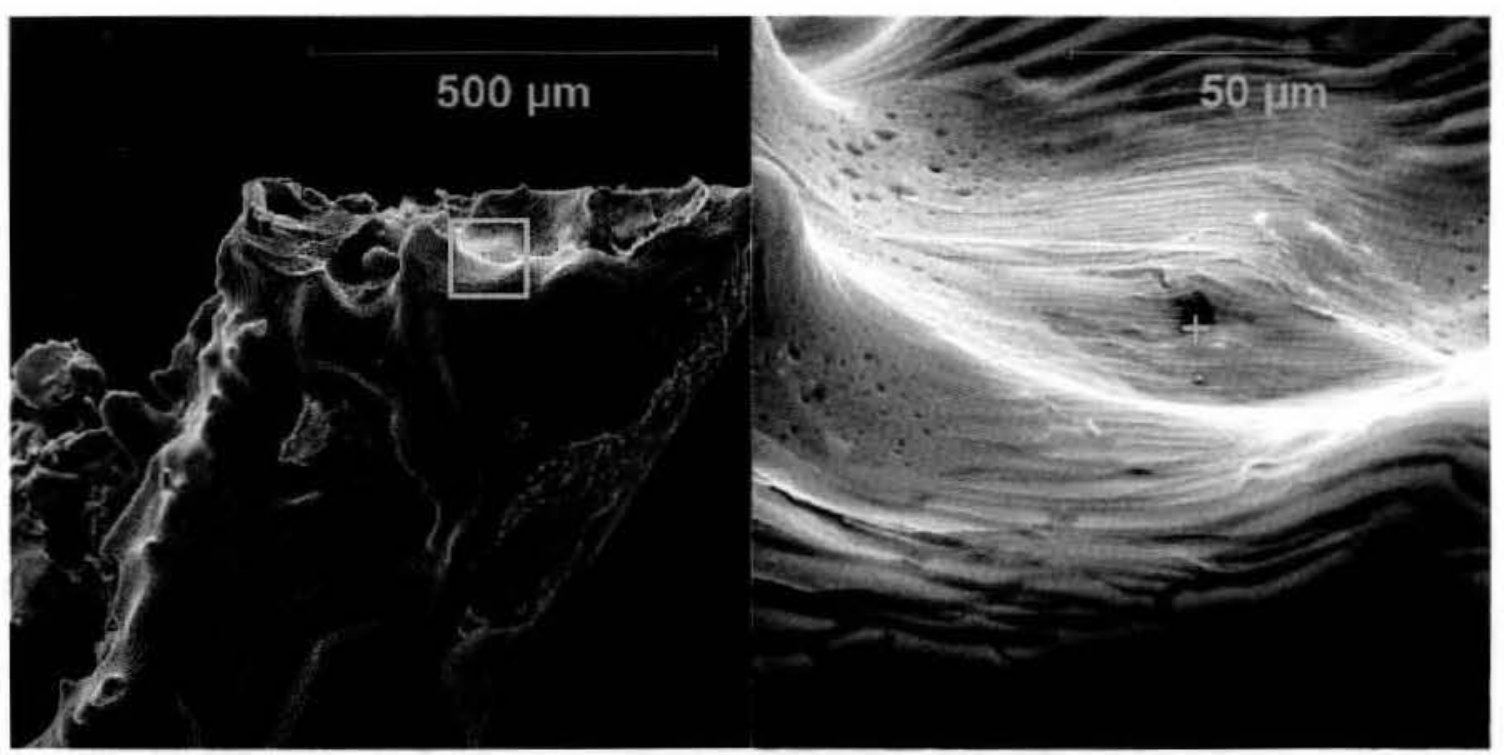

Figure E-5. EDS Spectrum from spot marked with + on Figure E-4

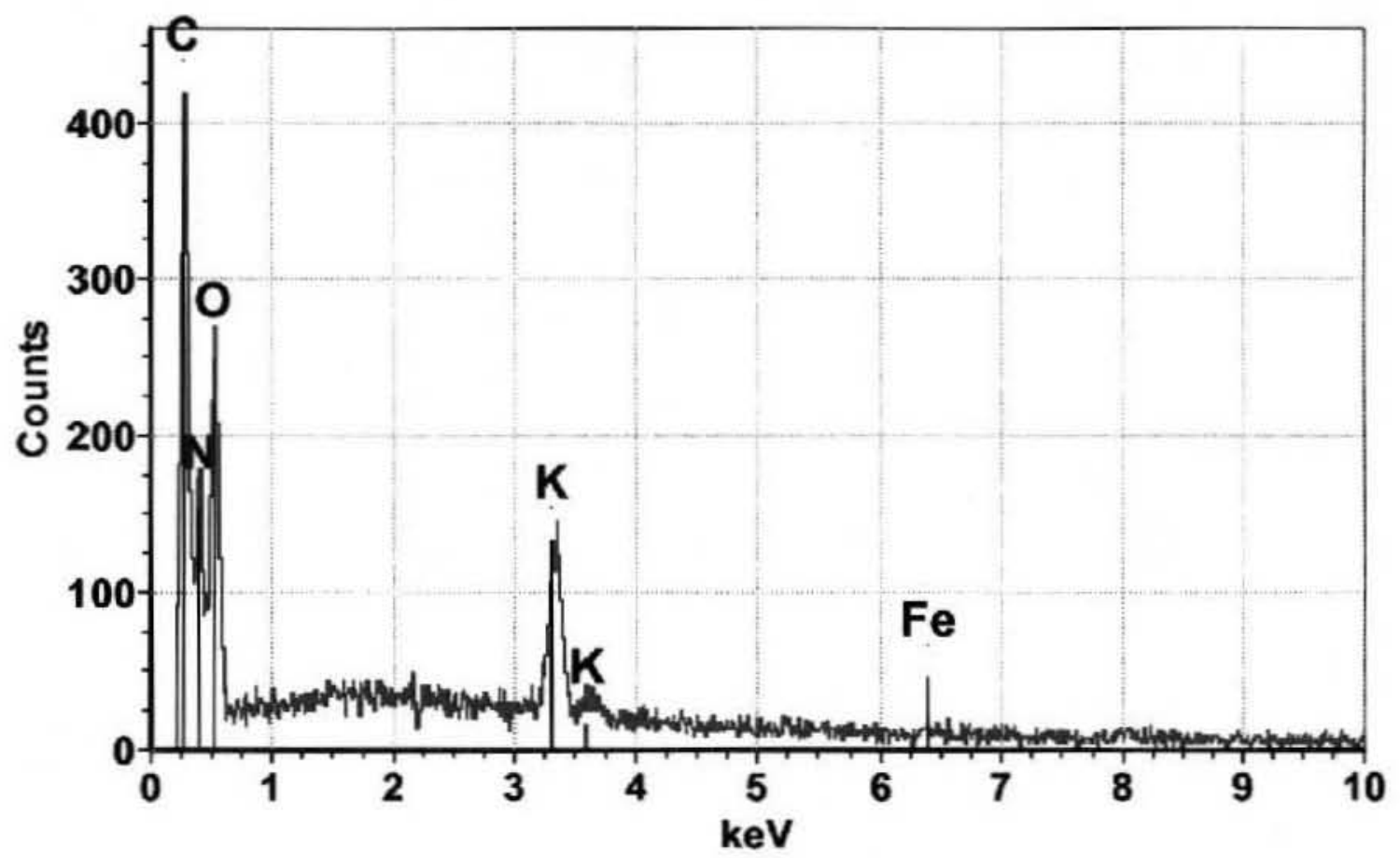




$$
\text { RPP-RPT-31293, Rev. } 0
$$

Figure E-6. Portion of sample not rinsed with methanol showing organic coating. Right image is blow up of area in box on left image

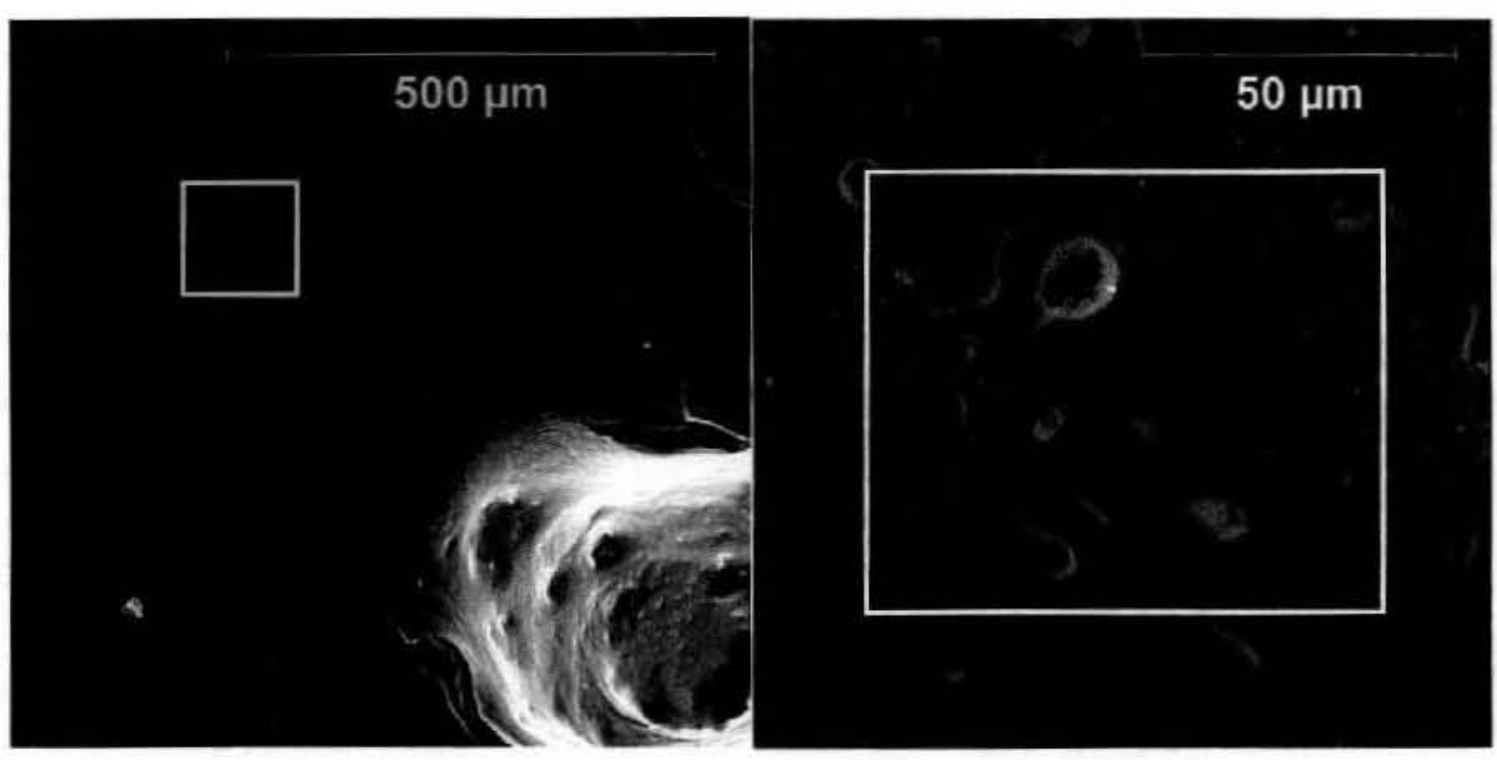

Figure E-7. EDS Spectrum from material in Figure E-6

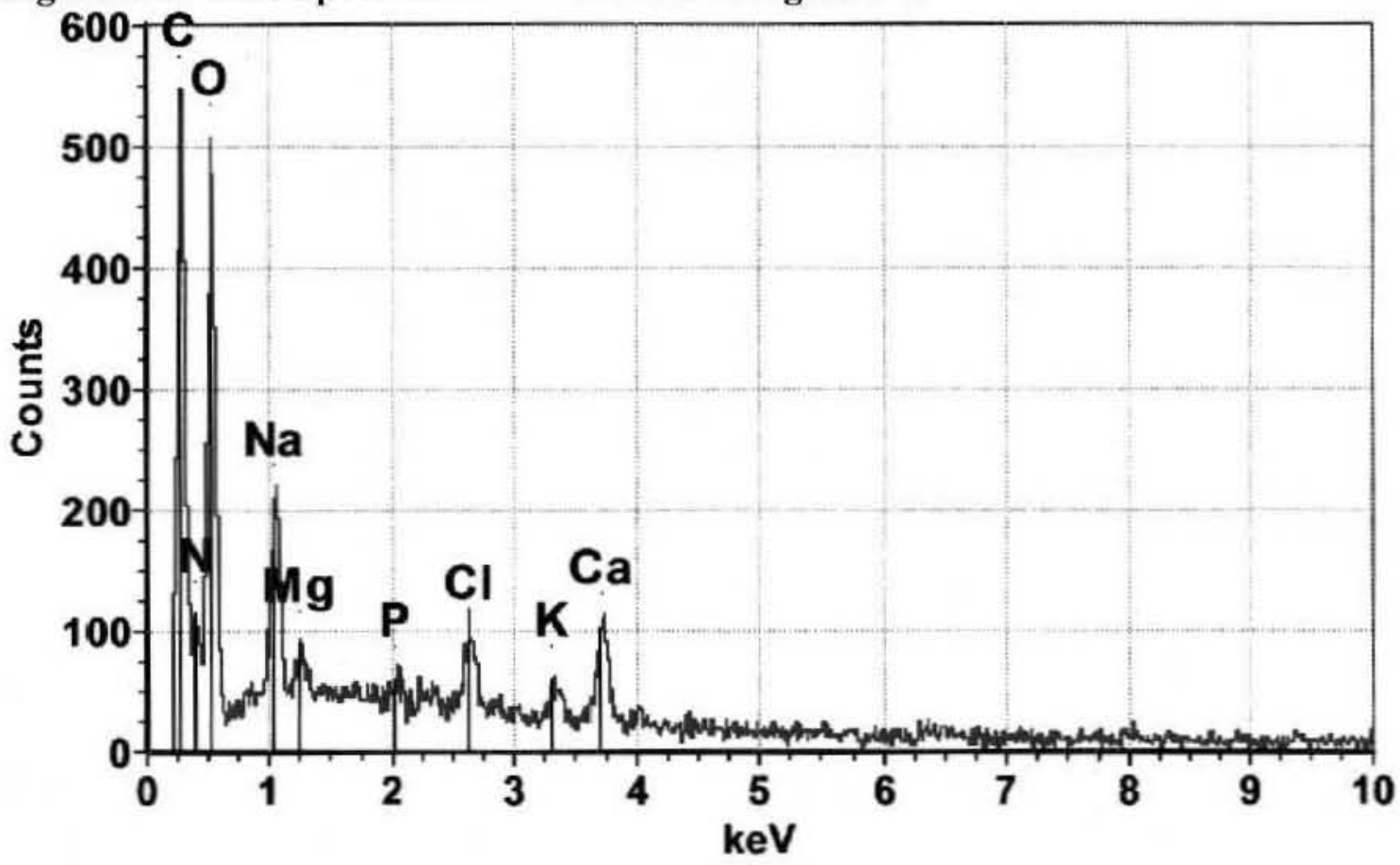




\section{Samples of DSC Residues from Crystalline and Floor Materials}

The two sample containers of crystalline and floor material that were analyzed by DCS with air as the purge gas were recovered and examined by the SEM. These small containers were mounted directly in the SEM specimen chamber for analysis. Figure E-8 is a pair of low magnification Backscatter Electron Images (BEI) of these two containers.

Figure E-8. Backscatter Electron Images of S06E001025 (left) and S06E001042 (right) containers after DSC analysis with air purge.

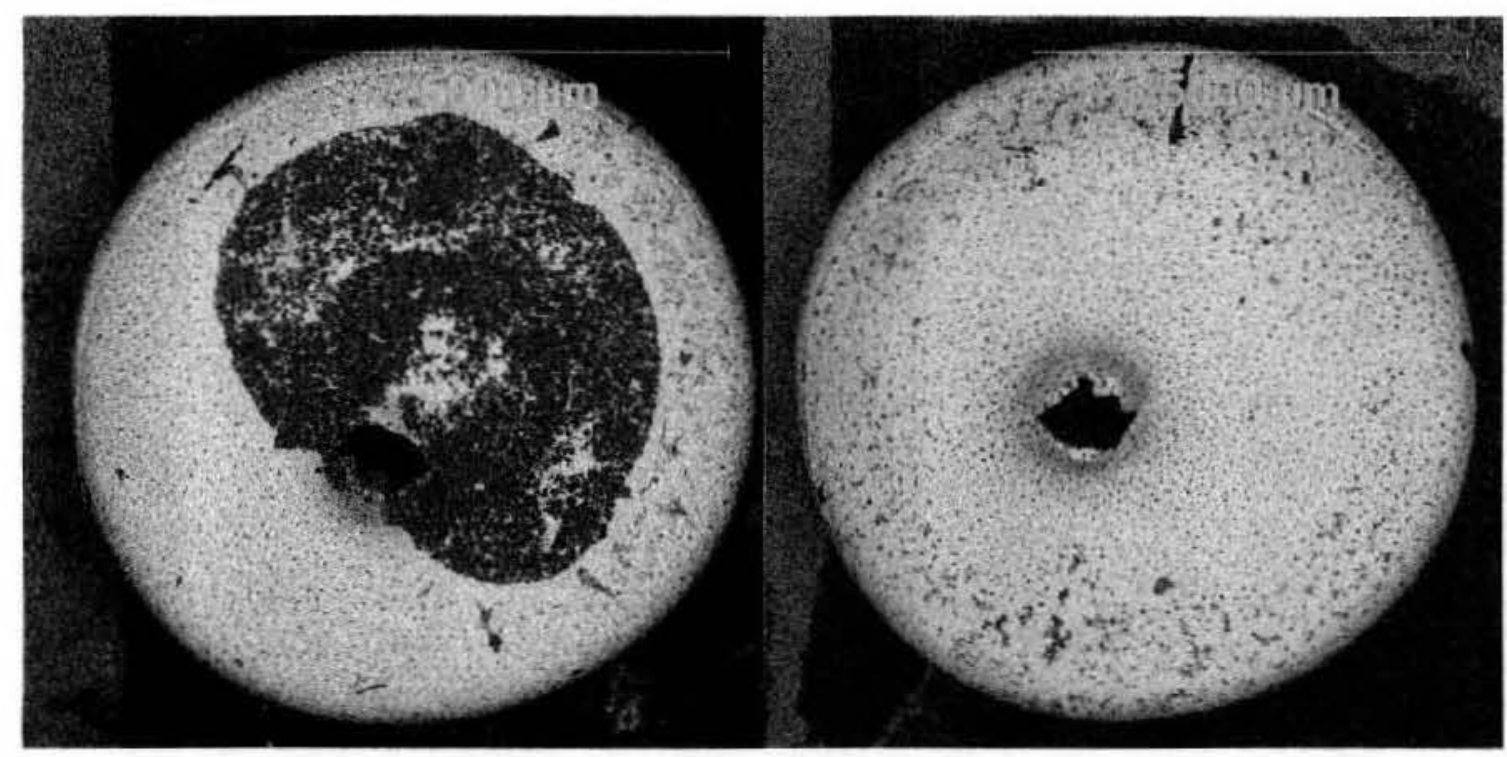

Both containers show a dark layer of particulate that was ejected from the inside, through the vent hole and deposited on the surface of the container. The sample S06E001025 material was apparently ejected with less forcefulness and a substantial amount of it remained in a continuous layer spreading over a portion of the container surface. The Sample S06E001042 material was apparently ejected more forcefully as evidenced by the more dispersed appearance of the residue across the surface of the container.

The EDS spectra of the particulate from each sample are shown in Figures E-9 (S06E001025) and E-10 (S06E001042). The more volatile carbon and nitrogen are depleted in these heated residues. The particulate from heating of S06E001025 shows a mix of more refractory elements, including $\mathrm{Na}, \mathrm{K}, \mathrm{Ca}, \mathrm{Mg}, \mathrm{S}$, and $\mathrm{P}$, while the residue from sample S06E001042 is dominated by $\mathrm{Na}$. 
Figure E-9. EDS Spectrum from dark material on DSC sample container from air purge run of Sample S06E001025.

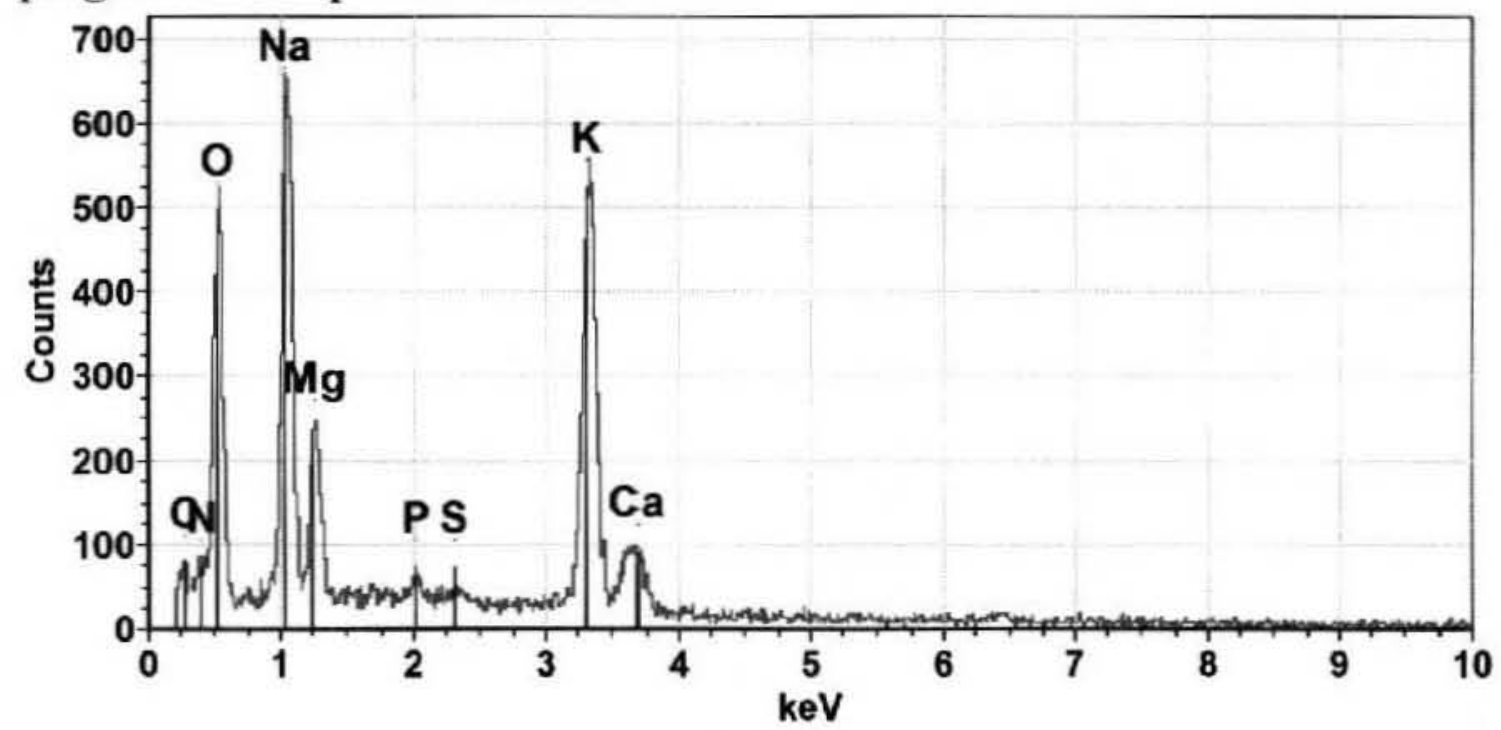

Figure E-10. EDS Spectrum from dark material on DSC sample container from air purge run of Sample S06E001042.

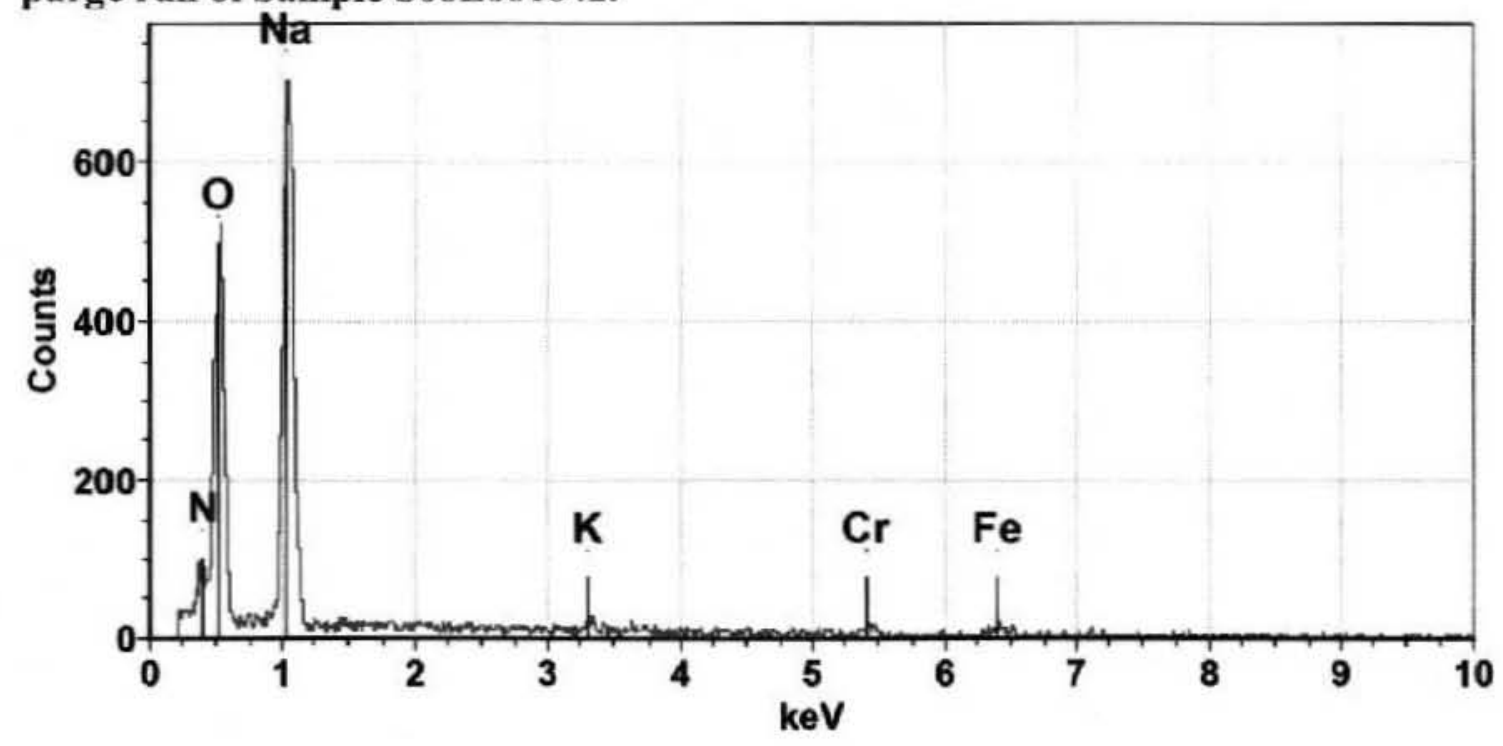


RPP-RPT-31293, Rev. 0

APPENDIX F

POI.ARIZFD I,IGHT MICROSCOPY RESUI,TS 
Polarized Light Microscopy Results for 702-AZ Floor Sample S06E00126 (unblended floor sample)

(1) The sample definitely contains $\mathrm{NaNO}_{3}$.

(2) There is non-specific evidence that the sample contains $\mathrm{NH}_{4} \mathrm{NO}_{3}$.

(3) There is no evidence of "life forms" - no mold spores or filaments, no singlecelled amoebas, no isotropic particulate that might be bacterial, etc.

The dark-colored viscous organic liquid phase (see Figure $F-1$ ) was definitely a major feature of the sample. There is no evidence of any particulate matter - living or otherwise - in this organic phase.

The major solid phases were the irregular rock-shaped crystals and elongated "canoeshaped" crystals prominent in Figure F-2. Both were highly birefringent, suggesting $\mathrm{NaNO}_{3}, \mathrm{NaNO}_{2}$, and/or $\mathrm{NH}_{4} \mathrm{NO}_{3}$. (Those are the most common, but not the only, highlybirefringent salt crystals). The rock-shaped crystals lack sufficiently defined edges to determine extinction position, so could be any of the candidate salts. For those crystals with defined edges (e.g., Figure F-3), the extinction position was mainly symmetrical, indicating $\mathrm{NaNO}_{3}$ unambiguously, though at least one crystal with defined edges had parallel extinction (i.e., was not $\mathrm{NaNO}_{3}$ ).

Ammonium nitrate crystallizes in several different phases at different temperatures. The phase that's stable at room temperature is described in the literature as "pseudo-tetragonal long prisms" with relatively high birefringence $\left(\eta_{z}-\eta_{x}=0.224\right)$. The elongated crystals visible in Figure $\mathrm{F}-2$ have high birefringence, so are consistent with $\mathrm{NH}_{4} \mathrm{NO}_{3}$. They also have parallel extinction, ruling out $\mathrm{NaNO}_{3}$. Since the XRD identified $\mathrm{NH}_{4} \mathrm{NO}_{3}$ but not $\mathrm{NaNO}_{2}$ in the sample, the elongated crystals are most likely $\mathrm{NH}_{4} \mathrm{NO}_{3}$.

Figure F-4 shows a higher-magnification look at the smaller particulate matter. The bright crystals are irregular in shape and have high birefringence, so are likely $\mathrm{NaNO}_{3}$ and/or $\mathrm{NH}_{4} \mathrm{NO}_{3}$. The smaller blue and orange crystals have lower birefringence, which is much more common than high birefringence, and could be any number of things, including $\mathrm{CaCl}_{2}-4 \mathrm{H}_{2} \mathrm{O}$ ( $\mathrm{Ca}$ and $\mathrm{Cl}$ having been identified in the $\mathrm{SEM} / \mathrm{EDS}$ ). 


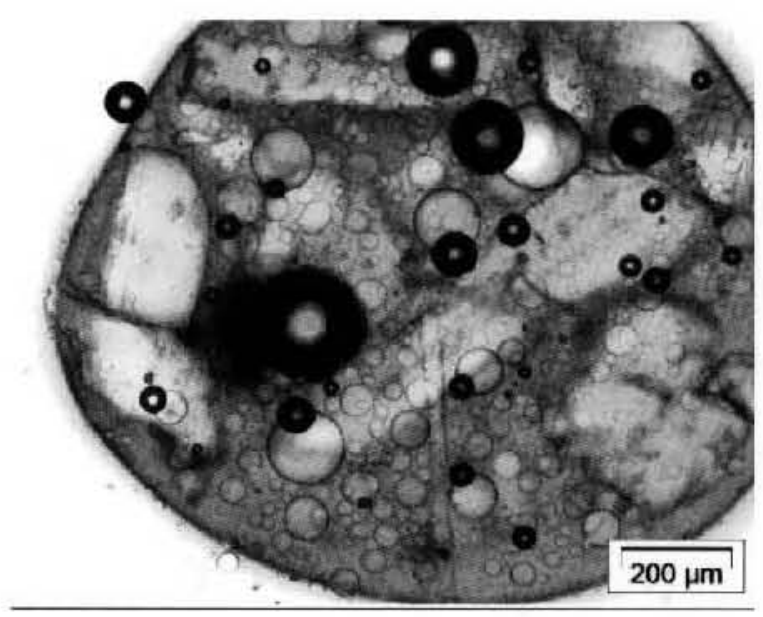

Figure F-1. Uncrossed polars, low mag; orange color is the organic phase, apparently a thick liquid (oil, grease?); large block crystals and elongated crystals visible within globule; dark circles are air bubbles; light circles are liquid bubbles, probably aqueous salt solution.

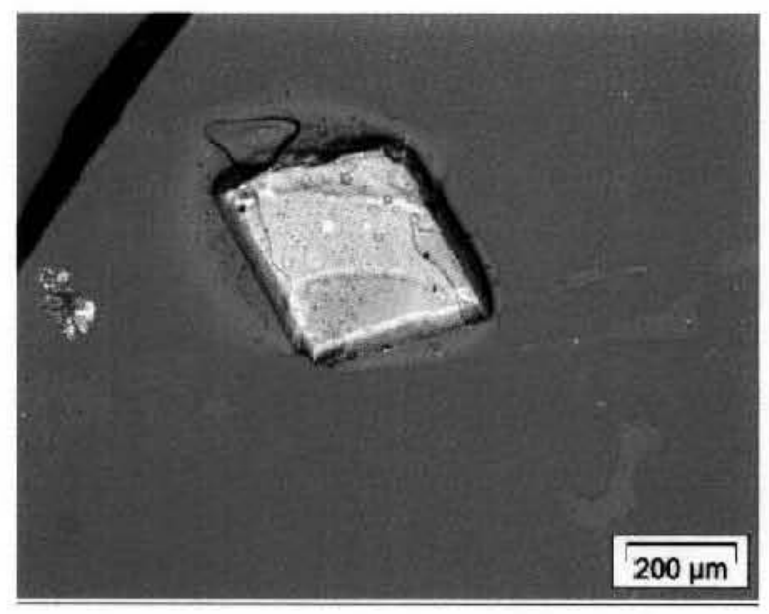

Figure F-3. Crossed polars with Red I compensator, low mag; single large crystal of NaNO3; orange organic visible around edges of crystal.

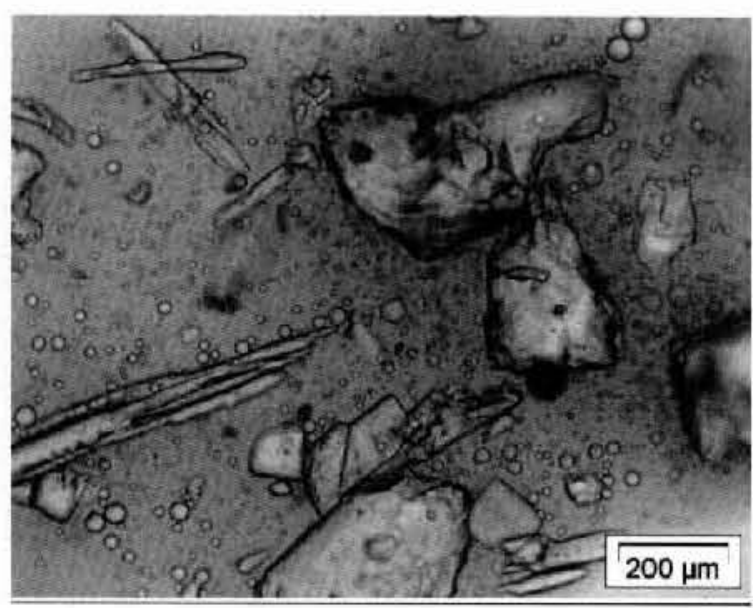

Figure F-2. Uncrossed polars, low mag; orange color of organic phase still visible but diluted; embedded crystals much more visible.

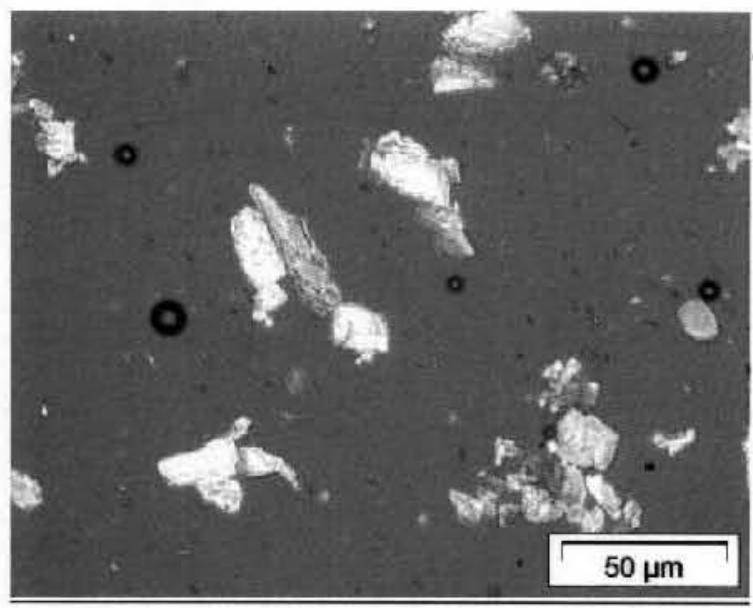

Figure F-4. Crossed polars with Red I compensator, high mag; focus on smaller particulate; bright crystals with irregular shape could be $\mathrm{NaNO}_{3}$ or $\mathrm{NH}_{4} \mathrm{NO}_{3}$. Smaller blue/orange crystals could be $\mathrm{CaCl}_{2} \cdot 4 \mathrm{H}_{2} \mathrm{O}$ (but could also be any of a myriad of other possibilities). 


\section{SO6E001042}

Polarized Light Microscopy Results for 702-AZ Floor Sample S06E001042 (blended floor samples)

The sample contains a mixture of large $\mathrm{NH}_{4} \mathrm{NO} 3$ crystals, large $\mathrm{NaNO}_{3}$ crystals, and very tiny crystals of indeterminate [by PLM] composition.

Figure F-5 is a low-mag overview of the sample. All of the larger bright particles are either $\mathrm{NH}_{4} \mathrm{NO}_{3}$ or $\mathrm{NaNO}_{3}$ - can't tell which is which in this view because of their irregular shape. Both crystals have very high birefringence $\left[\mathrm{NaNO}_{3}=0.26, \mathrm{NH}_{4} \mathrm{NO}_{3}=\right.$ $0.22]$, which makes them very difficult to tell apart from one another based on polarization colors. They're easy to tell apart by their interference figures (see next page) if you can detect the interference figures.

Figure F-6 is a close-up showing the prevalence of the $3^{\text {rd }}$ phase - the tiny particulate of unknown composition that coats the larger particles and fills the spaces between them.

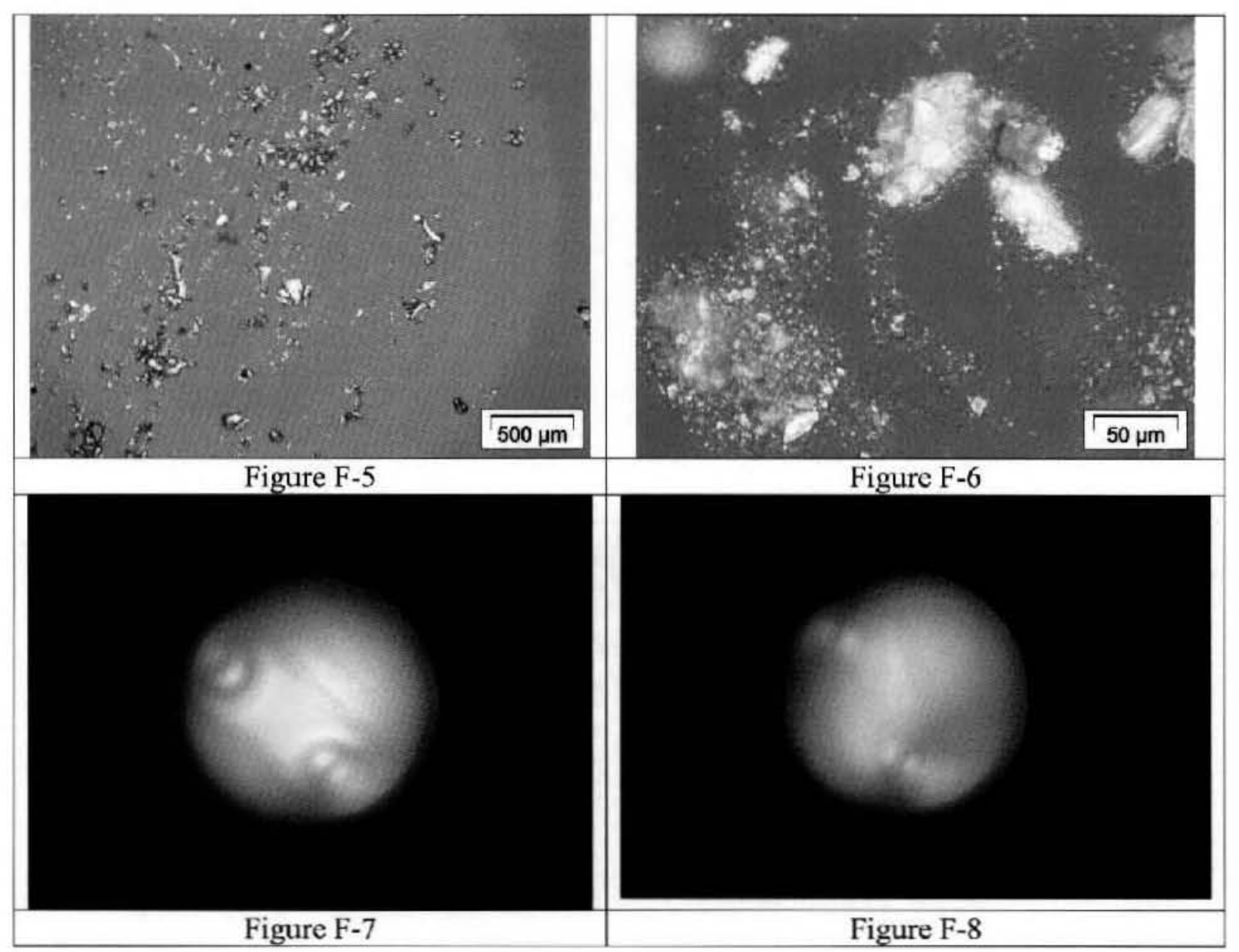


Figures F-7 and F-8 are conoscopic interference figures of the large $\mathrm{NH}_{4} \mathrm{NO}_{3}$ crystal in the center of Figure F-9. Figure F-7 has the quarter-wave plate inserted and Figure F-8 has it removed. The clearly biaxial figure indicates the crystal is $\mathrm{NH}_{4} \mathrm{NO}_{3}$ and not $\mathrm{NaNO}_{3} . \mathrm{NH}_{4} \mathrm{NO}_{3}$ crystals are orthorhombic at room temp (two optic axes - biaxial). $\mathrm{NaNO}_{3}$ crystals are rhombohedral but not orthorhombic - they belong to the hexagonal system, though they don't appear to be hexagonal at all. They have one optic axis (uniaxial).

The large crystal in Figure F-10 also gives a biaxial interference figure-it is $\mathrm{NH}_{4} \mathrm{NO}_{3}$.

In Figure F-11, the crystal marked ' $\mathrm{a}$ ' is $\mathrm{NH}_{4} \mathrm{NO}_{3}$, and the one marked ' $\mathrm{b}$ ' is $\mathrm{NaNO}_{3}$. The others in the figure gave no recognizable interference figure, so it could not be determined whether they were ammonium or sodium. Of all the crystals evaluated, "indeterminate" (no recognizable interference figure - could be either $\mathrm{NH}_{4} \mathrm{NO}_{3}$ or $\mathrm{NaNO}_{3}$ ) was the most common, followed by $\mathrm{NH}_{4} \mathrm{NO}_{3}$ (which was very common), and then by $\mathrm{NaNO}_{3}$ (which was rare). Figure F-12 is the highest magnification get of the tiny particulate - can not tell anything about it, except that it is birefringent.

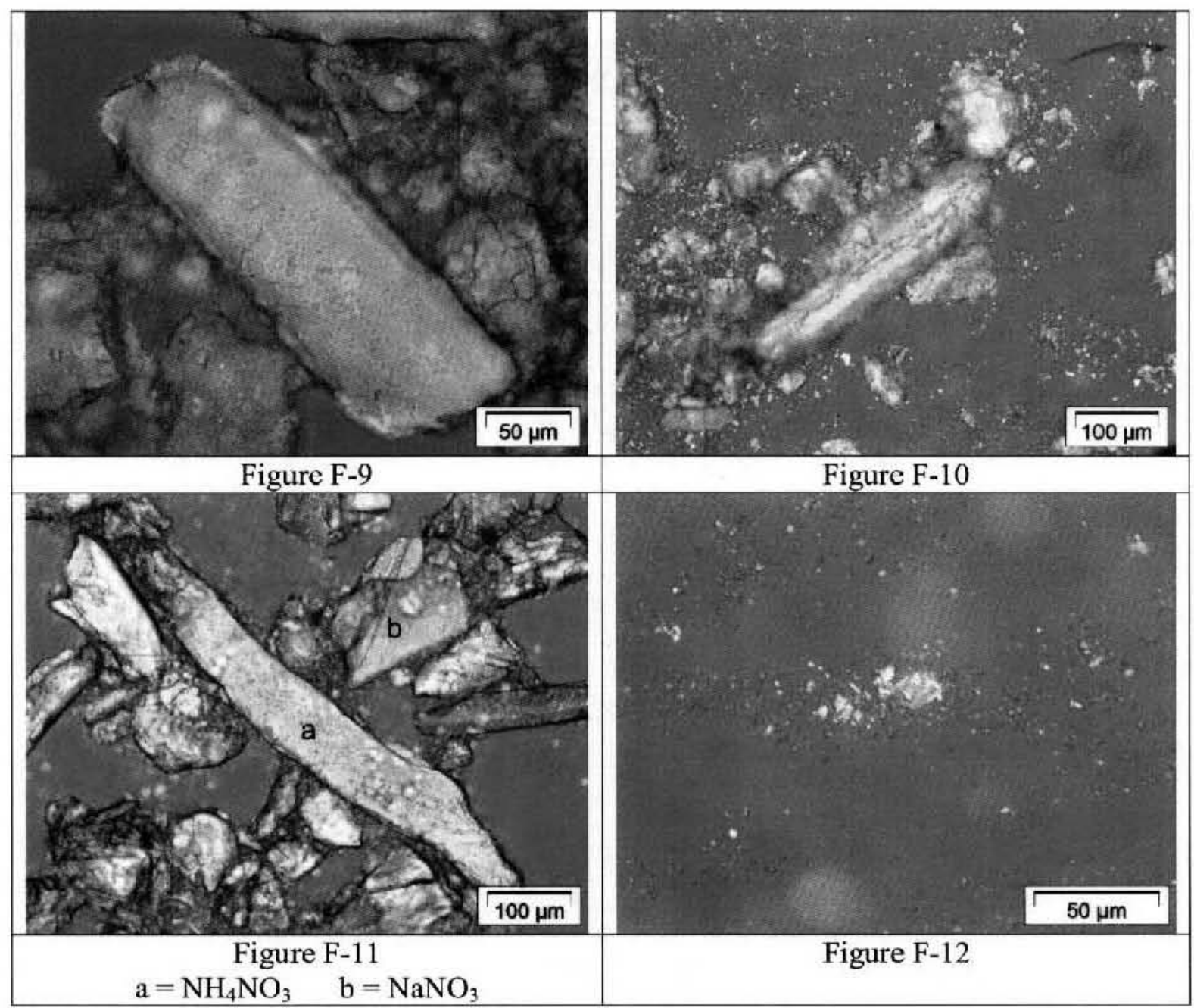


RPP-RPT-31293, Rev. 0

APPENDIX G

\section{$X$-RAY DIFFRACTION RESULTS}

G-i 


$$
\text { RPP-RPT-31293, Rev. } 0
$$

Figure G-1. XRD spectra of S06E001025 showing ammonium nitrate.

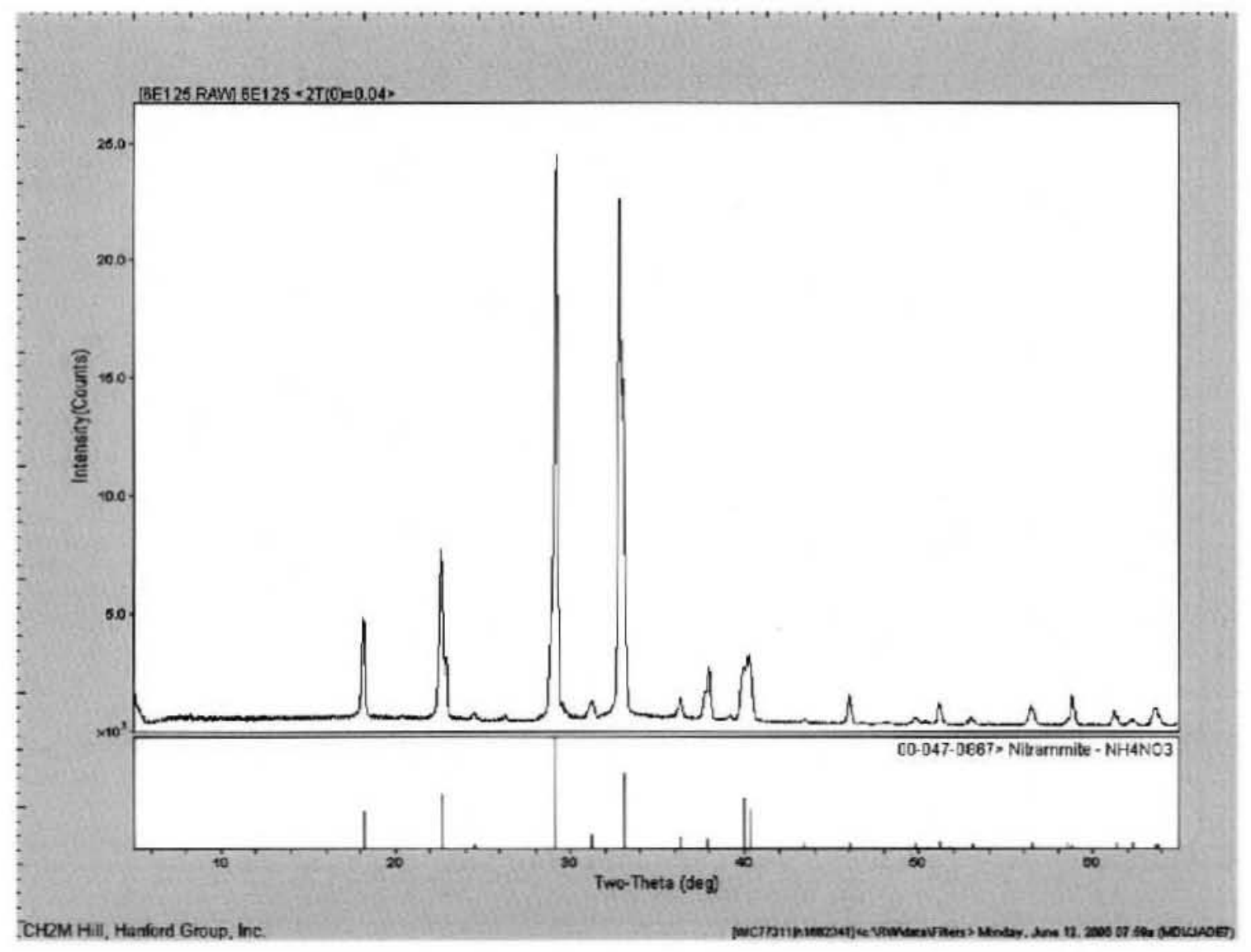


RPP-RPT-31293, Rev. 0

Figure G-2. Sample S06E001026 showing a mixture of ammonium nitrate and sodium nitrate.

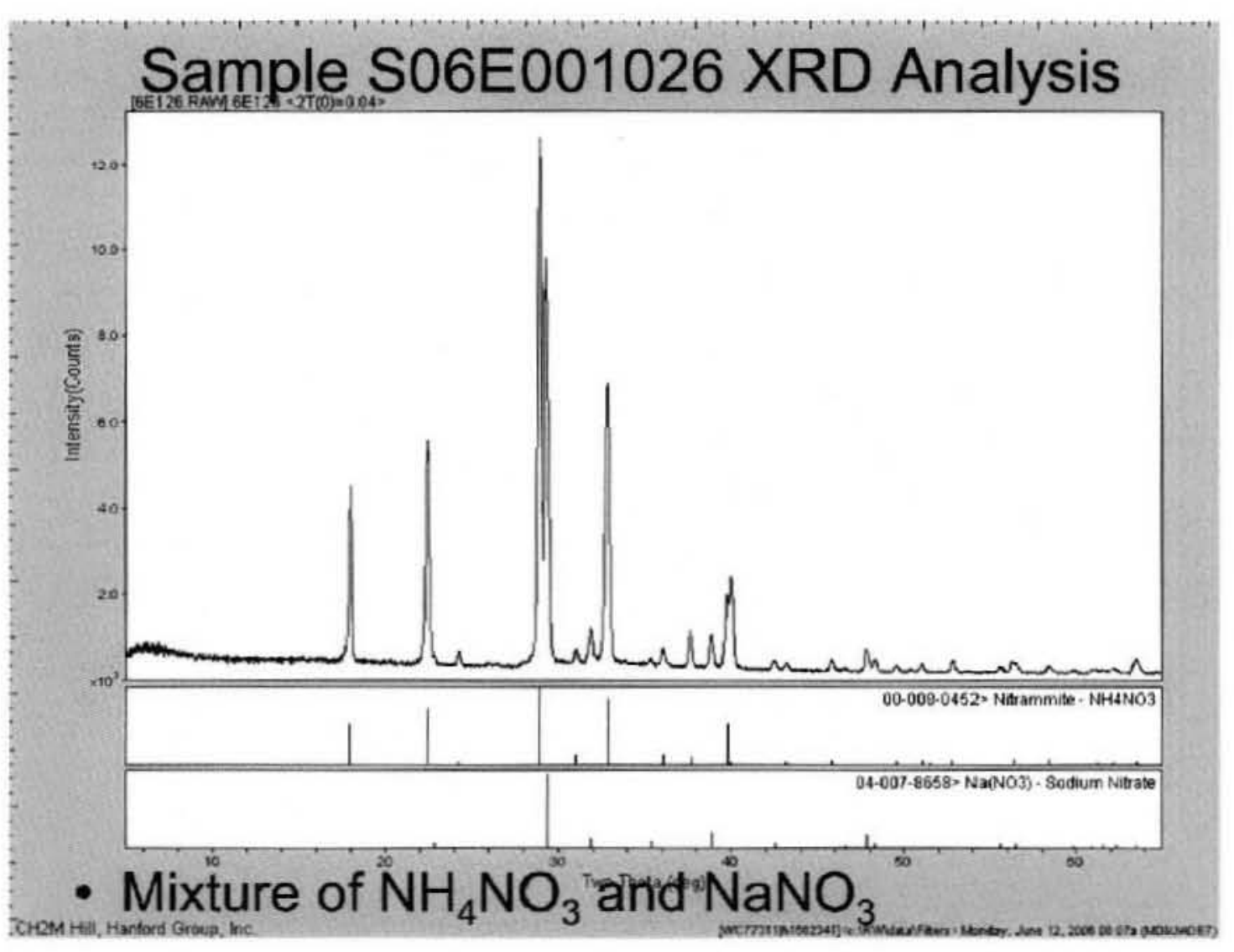


RPP-RPT-31293, Rev. 0

Figure G-3. Sample S06E001042 showing a mixture of ammonium nitrate and sodium nitrate.

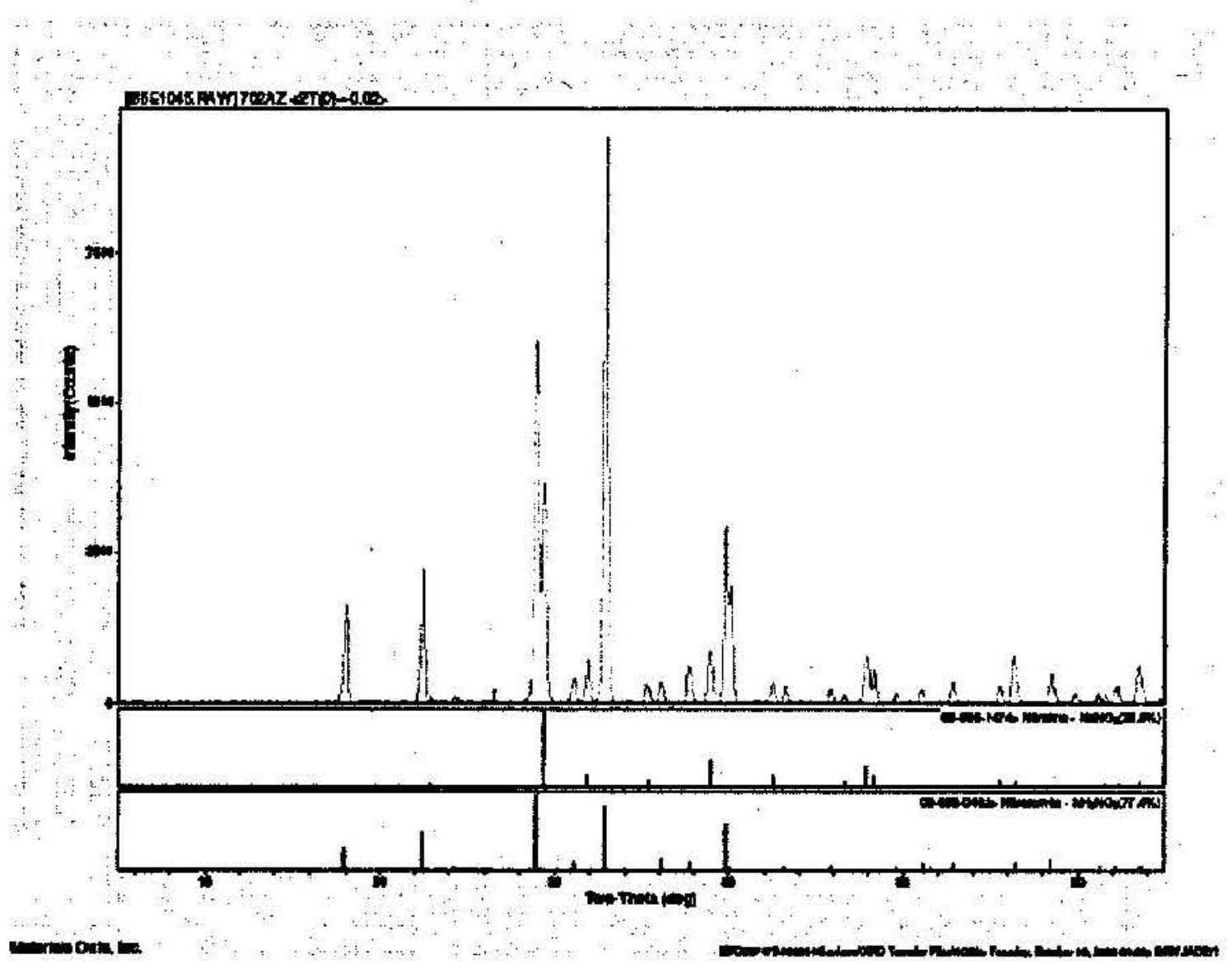


RPP-RPT-31293, Rev. 0 
Examination of the pipe interior revealed a loose scattering of coarse white particulate near the ends of the pipe section and a bulge of material attached to the interior wall of the pipe, approximately halfway along its length. A portion of the white particulate was recovered into a Petri dish and a spatula was inserted in the tube to sample the material adhering to the interior wall. This deposit was, in fact, a hollow blister that was firmly attached to the tube wall. The surface of the blister was thin and fragile and broke apart easily when scraped with the spatula. Several fragments of this material were recovered.

Figure H-1. The field image, below shows several of the small white particles and large flakes from the blister

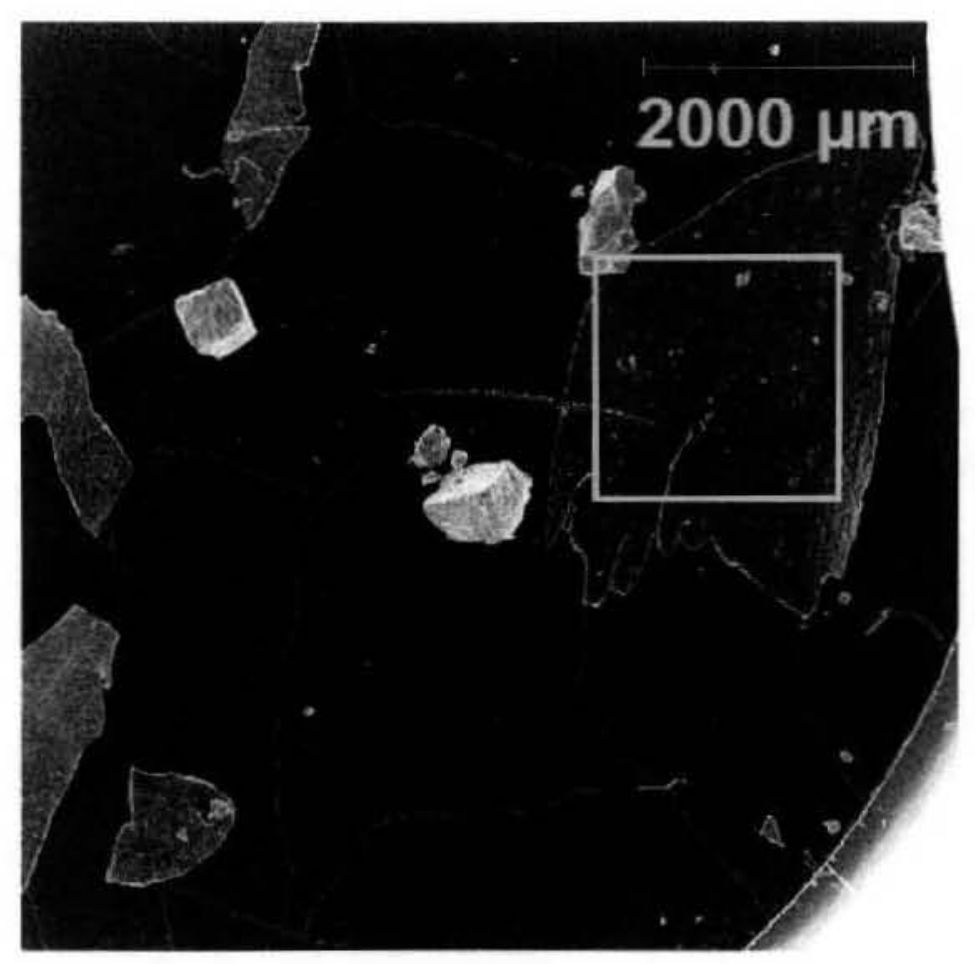


Figure H-2. An EDS X-Ray spectrum from the center of the yellow box shows that carbon makes up the dominant element in the blister material

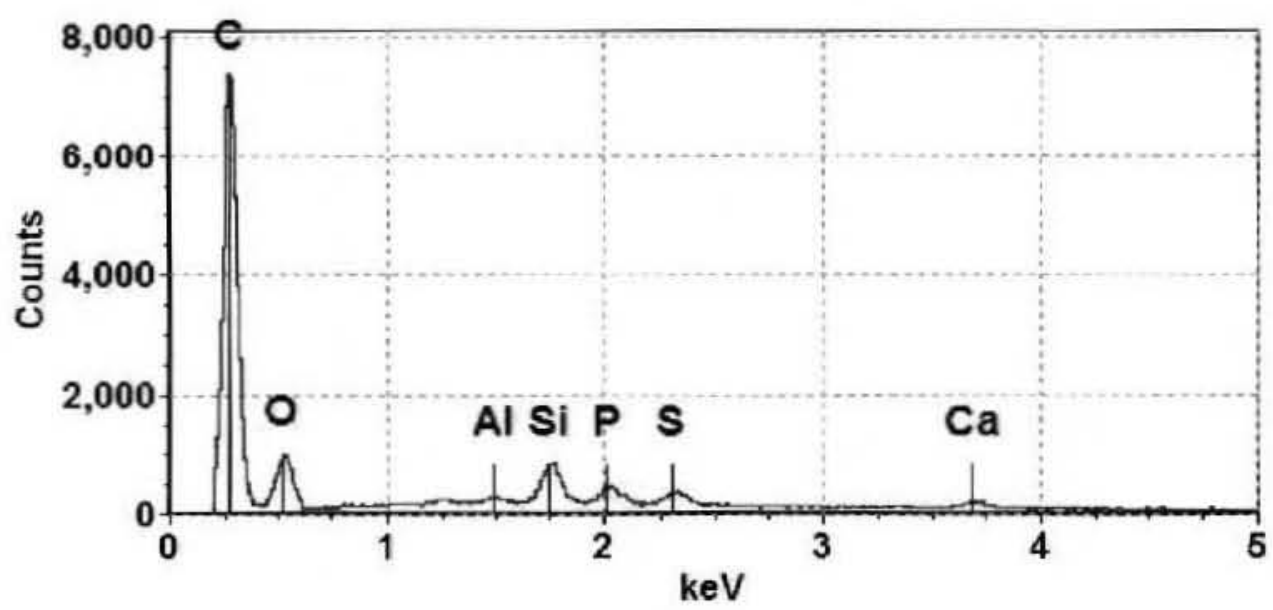

Figure H-3. The white particulate was observed to be coarse aggregates of finegrained material with a chemical composition (again, obtained from the center of the yellow box) that is consistent with a zeolite.

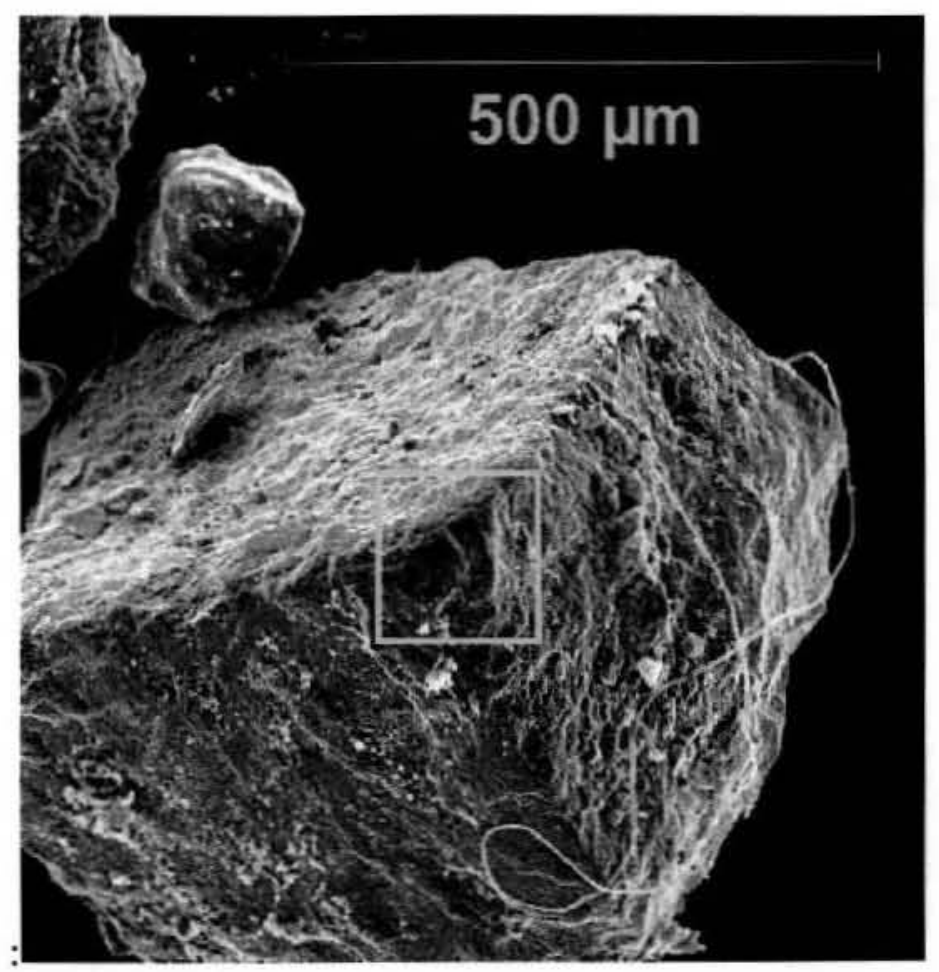


RPP-RPT-31293, Rev. 0

Figure H-4. EDS spectrs of material from Figure H-3.

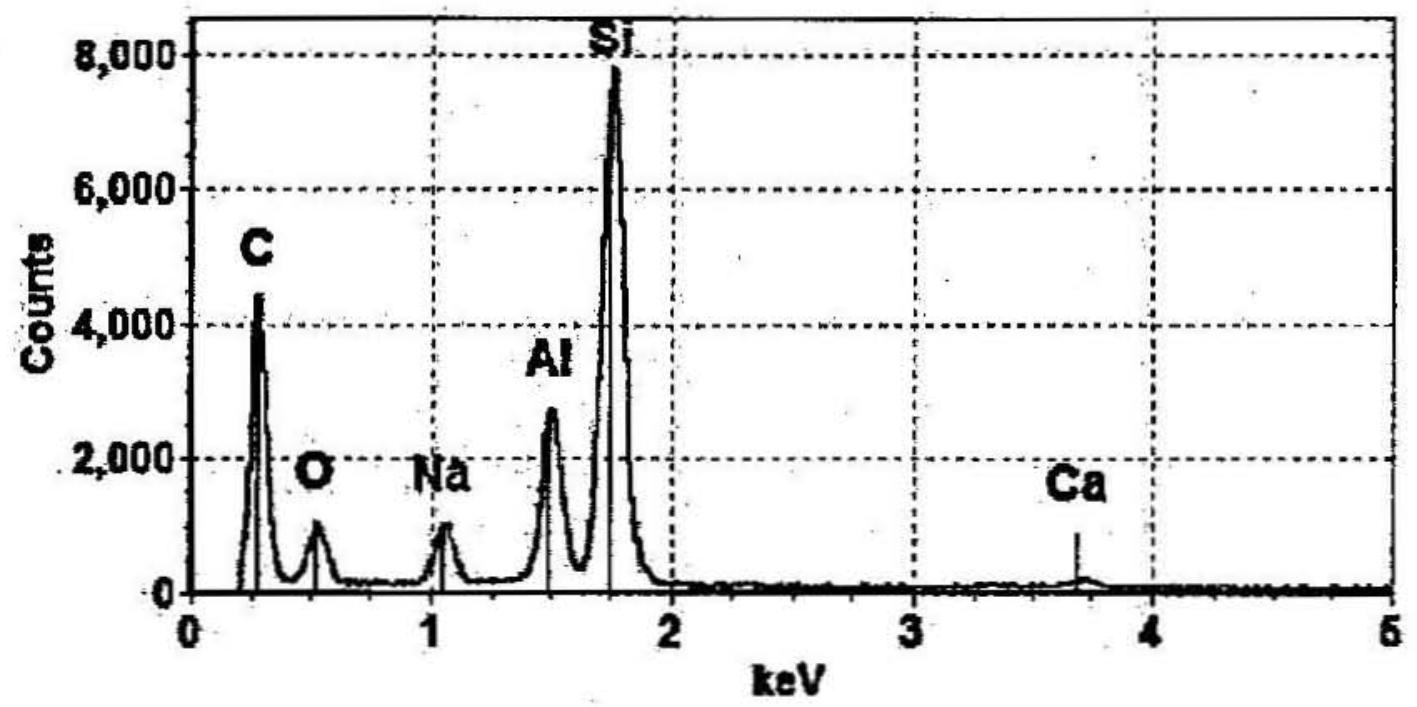

